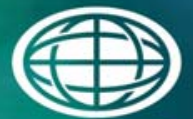

Savannah River

National Laboratory ${ }^{m}$

OPERATED BY SAVANNAH RIVER NUCLEAR SOLUTIONS

\title{
Alternate Reductant Cold Cap Evaluation Furnace Phase II Testing
}

F.C. Johnson

ME Stone

D.H. Miller

September 2014

SRNL-STI-2014-00157, Revision 0 
SRNL-STI-2014-00157

Revision 0

\section{DISCLAIMER}

This work was prepared under an agreement with and funded by the U.S. Government. Neither the U.S. Government or its employees, nor any of its contractors, subcontractors or their employees, makes any express or implied:

1. warranty or assumes any legal liability for the accuracy, completeness, or for the use or results of such use of any information, product, or process disclosed; or

2. representation that such use or results of such use would not infringe privately owned rights; or

3. endorsement or recommendation of any specifically identified commercial product, process, or service.

Any views and opinions of authors expressed in this work do not necessarily state or reflect those of the United States Government, or its contractors, or subcontractors.

\section{Printed in the United States of America \\ Prepared for U.S. Department of Energy}


Keywords: alternate reductant, cold cap evaluation furnace (CEF)

Retention: Permanent

\title{
Alternate Reductant Cold Cap Evaluation Furnace Phase II Testing
}

\author{
F.C. Johnson \\ M.E. Stone \\ D.H. Miller
}

September 2014

Prepared for the U.S. Department of Energy under contract number DE-AC09-08SR22470.

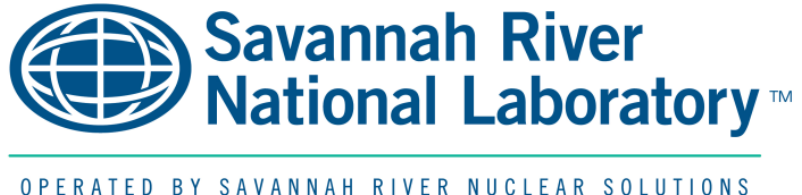




\section{REVIEWS AND APPROVALS}

\section{AUTHORS:}

F.C. Johnson, Process Technology Programs Date

M.E. Stone, Process Technology Programs Date

D.H. Miller, Engineering Process Development Date

TECHNICAL REVIEW:

D.K. Peeler, Process Technology Programs, Reviewed per E7 2.60 Date

M.R. Williams, Process Technology Programs, Reviewed per E7 2.60

Date

D.P. Lambert, Process Technology Programs, Reviewed per E7 2.60

Date

T.L. White, Analytical Development, Reviewed per E7 2.60

Date

APPROVAL:

D.H. McGuire, Manager

Date

Process Technology Programs

S.L. Marra, Manager

Date

Environmental \& Chemical Process Technology Research Programs

E.J. Freed, Manager

Date

DWPF and Saltstone Engineering 


\section{PREFACE OR ACKNOWLEDGEMENTS}

The authors would like to thank: Jake Amoroso, David Best, Mona Blume, Paul Burket, Alex Choi, Jeff Coughlin, Gene Daniel, Mark Duignan, Jon Duvall, Mike Feller, Andy Foreman, Mark Fowley, Holly Hall, Dave Healy, Minnie Hightower, Dan Lambert, Mike Lee, Dale Marzolf, Wanda Matthews, Dave McGuire, Bridget Miller, David Mitchell, John Pareizs, Monica Philips, Mike Restivo, Whitney Riley, Dianne Scott, Geoff Smoland, Doug Sumpter, Beverly Wall, Frances Williams, Mike Williams, Vickie Williams, Phyllis Workman, Kim Wyszynski and Jack Zamecnik for their support throughout system setup, testing and sample analysis. 


\section{EXECUTIVE SUMMARY}

Savannah River Remediation (SRR) conducted a Systems Engineering Evaluation (SEE) to determine the optimum alternate reductant flowsheet for the Defense Waste Processing Facility (DWPF). Specifically, two proposed flowsheets (nitric-formic-glycolic and nitric-formic-sugar) were evaluated based upon results from preliminary testing. Comparison of the two flowsheets among evaluation criteria indicated a preference towards the nitric-formic-glycolic flowsheet. Further research and development of this flowsheet eliminated the formic acid, and as a result, the nitric-glycolic flowsheet was recommended for further testing.

Based on the development of a roadmap for the nitric-glycolic acid flowsheet, Waste Solidification Engineering (WS-E) issued a Technical Task Request (TTR) to address flammability issues that may impact the implementation of this flowsheet. Melter testing was requested in order to define the DWPF flammability envelope for the nitric-glycolic acid flowsheet. The Savannah River National Laboratory (SRNL) Cold Cap Evaluation Furnace (CEF), a 1/12 ${ }^{\text {th }}$ scale DWPF melter, was selected by the SRR Alternate Reductant project team as the melter platform for this testing. The overall scope was divided into the following sub-tasks as discussed in the Task Technical and Quality Assurance Plan (TTQAP):

- Phase I - A nitric-formic acid flowsheet melter test (unbubbled) to baseline the CEF cold cap and vapor space data to the benchmark melter flammability models

- Phase II - A nitric-glycolic acid flowsheet melter test (unbubbled and bubbled) to:

o Define new cold cap reactions and global kinetic parameters in support of the melter flammability model development

o Quantify off-gas surging potential of the feed

o Characterize off-gas condensate for complete organic and inorganic carbon species

After charging the CEF with cullet from Phase I CEF testing, the melter was slurry-fed with glycolic flowsheet based SB6-Frit 418 melter feed at 36\% waste loading and was operated continuously for 25 days. Process data was collected throughout testing and included melter operation parameters and off-gas chemistry. In order to generate off-gas data in support of the flammability model development for the nitric-glycolic flowsheet, vapor space steady state testing in the range of $\sim 300-750^{\circ} \mathrm{C}$ was conducted under the following conditions, (i) 100\% (nominal and excess antifoam levels) and $125 \%$ stoichiometry feed and (ii) with and without argon bubbling. Adjustments to feed rate, heater outputs and purge air flow were necessary in order to achieve vapor space temperatures in this range. Surge testing was also completed under nominal conditions for four days with argon bubbling and one day without argon bubbling.

The following items are notable observations and results from Phase II testing.

- Very little glycolate is evaporated from the feed and nearly all $(>99.5 \%)$ of the glycolate fed to the melter is destroyed.

- The amount of uncombusted organics in the off-gas is negligible.

- The REDuction/OXidation (REDOX) of the glasses collected from the pour stream were generally fully oxidized (all $\mathrm{Fe}^{3+}$ ), which was not expected based on anticipated values for the melter feeds based on sealed crucible studies $\left(\mathrm{Fe}^{2+} / \sum \mathrm{Fe}\right.$ in the range of $\left.0.25-0.42\right)$.

- The appearance of the cold cap during nitric-glycolic testing was no different than that of the nitric-formic flowsheet during non-bubbled steady state testing. 
- There was no evidence of foaming in the melter during any of the test conditions.

- At vapor space temperatures above $500^{\circ} \mathrm{C}$ a glass production rate in the range of $27-30 \mathrm{~g} / \mathrm{min}$ was achieved for the nitric-formic flowsheet and 31-44 $\mathrm{g} / \mathrm{min}$ was attained for the nitric-glycolic flowsheet during non-bubbled steady state conditions.

- An obvious difference in the consistency of the melter feeds of different acid stoichiometries was observed; $100 \%$ was quite thin $(5 \mathrm{cP})$, while the $125 \%$ was considerably thicker $(15 \mathrm{cP})$.

- Lard-like material was found in the drums of the Sludge Receipt and Adjustment Tank (SRAT) product prior to mixing. It is likely that this material is organic and further analysis is planned. A suitable analytical approach is under development and results will be issued in a separate report.

- Iridescent flakes were observed in the off-gas condensate system solids. Based on the limited analyses the material is amorphous and also contains quartz and magnetite. No further investigation of how and why this material formed has been pursued at present time.

Based on the results from this testing, the following items are recommended for future study in support of the implementation of the nitric-glycolic flowsheet.

- Further REDOX testing and data interpretation are necessary in order to more thoroughly understand the effect of the nitric-glycolic flowsheet on glass REDOX during melter runs, as well as the impact of the testing protocol.

- Further testing to determine the impact of acid stoichiometry on the rheological properties of SME product. Increasing yield stress as acid stoichiometry increases has been noted during CPC testing, thus a better understanding of when increased acid stoichiometry begins to result in higher yield stress is needed.

- Further analysis of the flakes that were present in some of the solids collected from the off-gas condensate system filters. Determine if there are any negative impacts to processing.

- Further analysis of the lard-like material found in some of the drums of SRAT product. Determine if there are any negative impacts to processing.

The following item is recommended for an enhanced understanding of the nitric-glycolic flowsheet.

- Conduct melt rate testing using the melt rate furnace (MRF) and potentially the slurry fed melt rate furnace (SMRF) with melter feeds fabricated with leftover CEF SRAT products to compare the nitric-formic and nitric-glycolic flowsheets. These samples should then be submitted for analysis by X-ray computed tomography (CT) so that more quantitative comparisons can be made. Melt rate testing under bubbled conditions would also be of interest. The CEF could also be operated under nominal conditions to generate bubbled melt rate data under nominal conditions if feed is available. 


\section{TABLE OF CONTENTS}

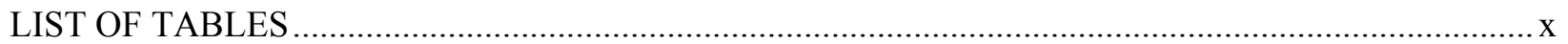

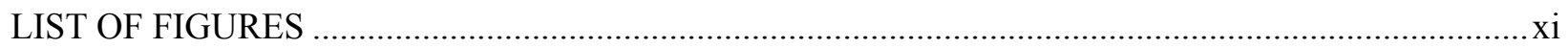

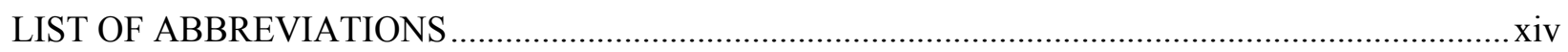

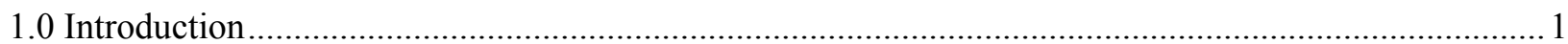

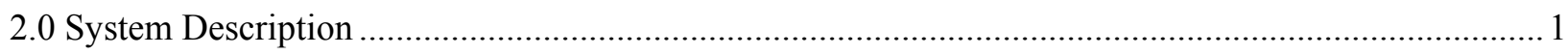

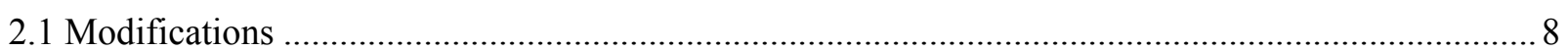

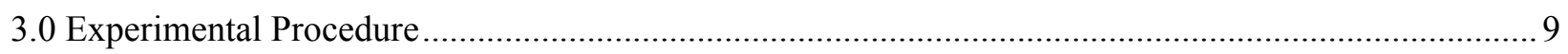

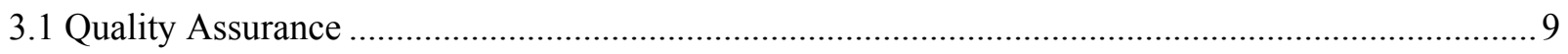

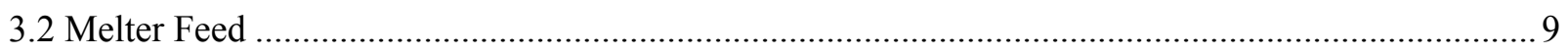

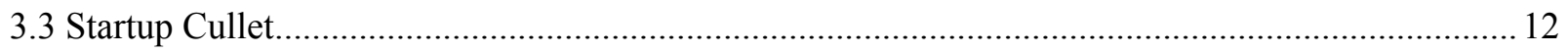

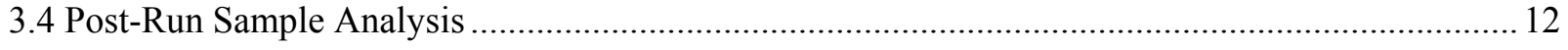

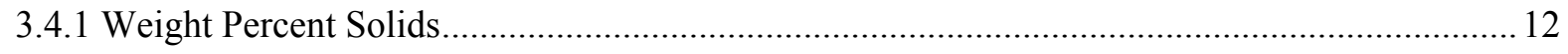

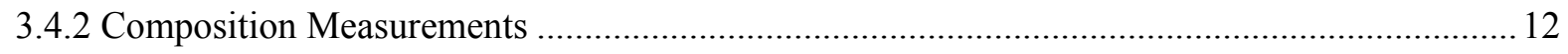

3.4.3 Reduction/Oxidation (REDOX) Measurements ................................................................. 13

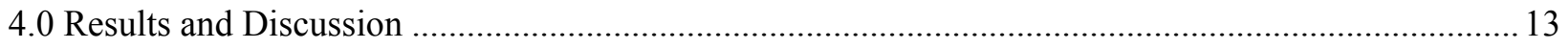

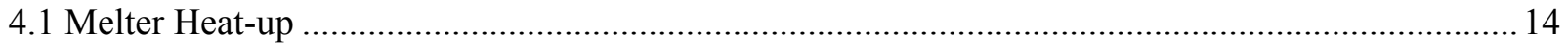

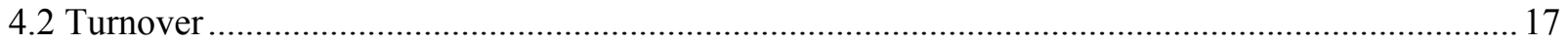

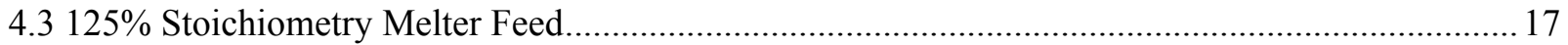

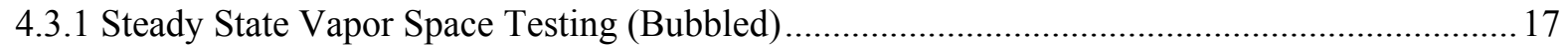

4.3.2 Steady State Vapor Space Conditions (Non-Bubbled) ….....................................................2

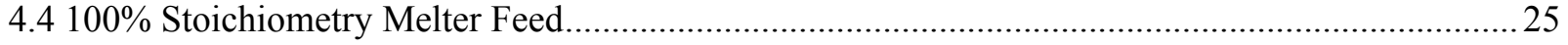

4.4.1 Steady State Vapor Space Testing (Non-Bubbled) ..................................................................25

4.4.2 Steady State Vapor Space Testing (Bubbled) .........................................................................29

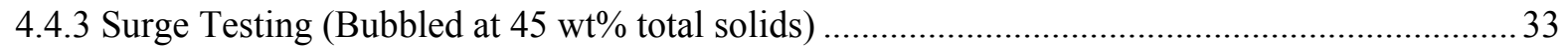

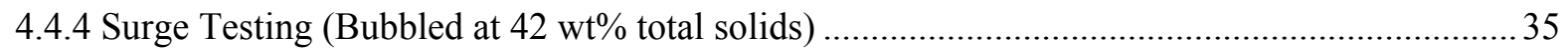

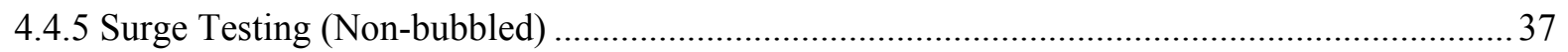

$4.5100 \%$ Stoichiometry Melter Feed with Antifoam Spike (Non-bubbled) ......................................... 39

4.5.1 Steady State Vapor Space Testing ( 2X Antifoam Spike, Non-Bubbled) ............................... 40

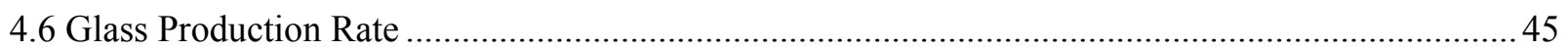

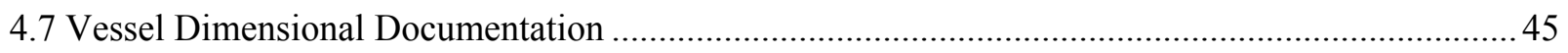

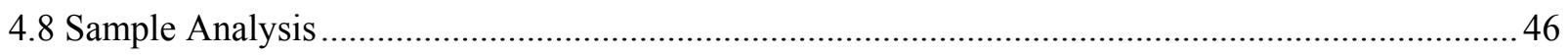

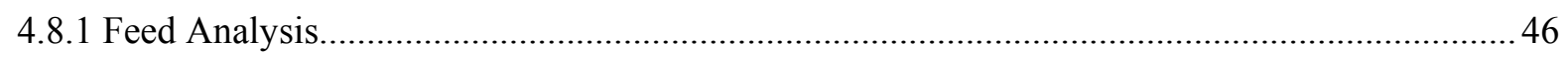

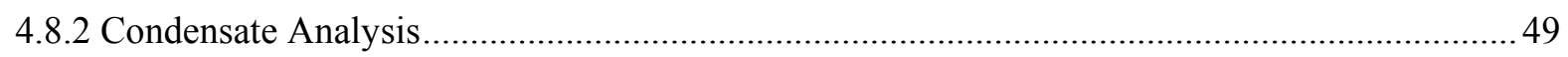




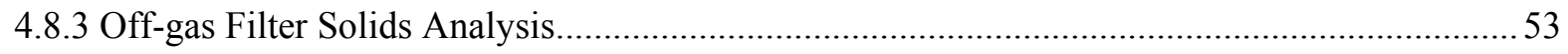

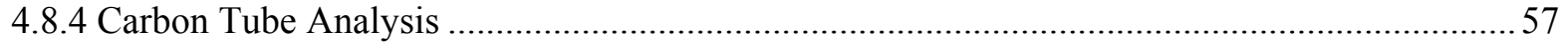

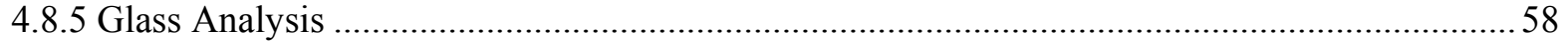

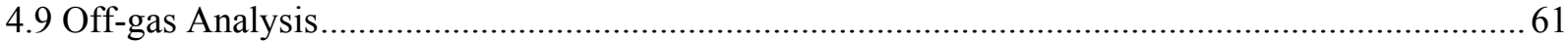

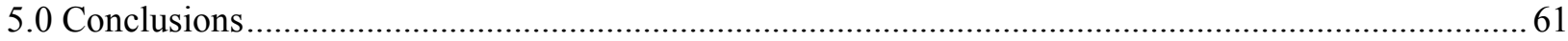

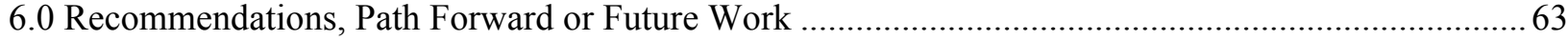

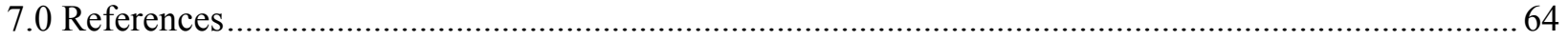

Appendix A . Supplementary Figures and Tables ........................................................................... 


\section{LIST OF TABLES}

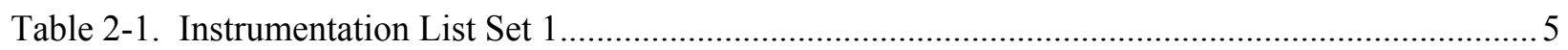

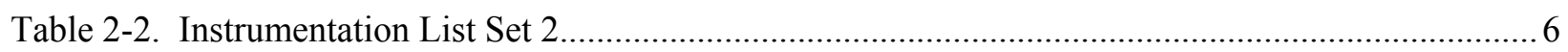

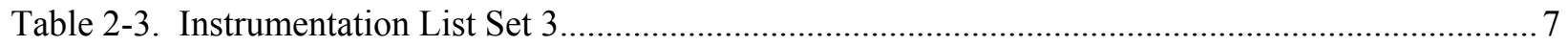

Table 3-1. Physical Properties of the Harrell SB6I 100\% and 125\% SRAT Products ............................ 10

Table 3-2. Harrell SB6I SRAT Product Compositions (wt \% calcine solids basis) ................................. 10

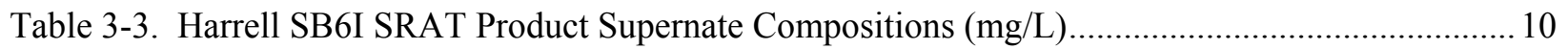

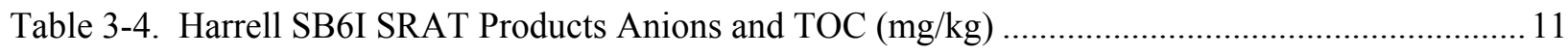

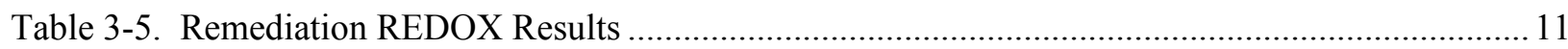

Table 3-6. Remediation of Harrell SRAT Product (kg/30-gallon drum) …........................................... 12

Table 4-1. Summary of the Vapor Space Temperature Steady State Testing Conditions ........................ 13

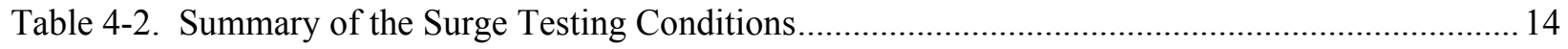

Table 4-3. Test Conditions, Dates and Approximate Times Set 1 ........................................................ 15

Table 4-4. Test Conditions, Dates and Approximate Times Set 2 ..................................................... 16

Table 4-5. 125\% Bubbled Steady State Vapor Space Temperature Test Conditions .............................. 17

Table 4-6. 125\% Bubbled Steady State Vapor Space Temperature Test Conditions .............................. 18

Table 4-7. 125\% Non-Bubbled Steady State Vapor Space Temperature Test Conditions ....................... 21

Table 4-8. 100\% Non-Bubbled Steady State Vapor Space Temperature Test Conditions ........................25

Table 4-9. 100\% Bubbled Steady State Vapor Space Temperature Test Conditions ............................... 29

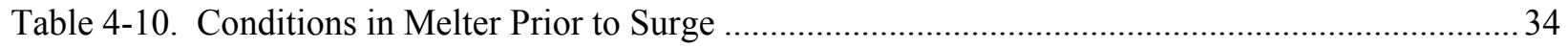

Table 4-11. Melter Conditions During Bubbled Surge Testing .............................................................. 35

Table 4-12. Melter Conditions During Non-Bubbled Surge Testing..................................................... 37

Table 4-13. Antifoam Spike Non-Bubbled Steady State Vapor Space Temperature Test Conditions .......41

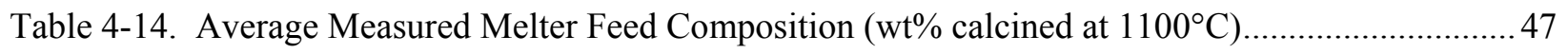

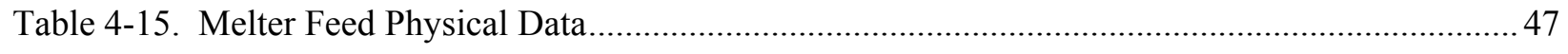

Table 4-16. Average Measured Melter Feed Anions (mg/Kg) ........................................................... 48

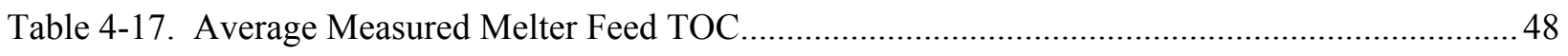

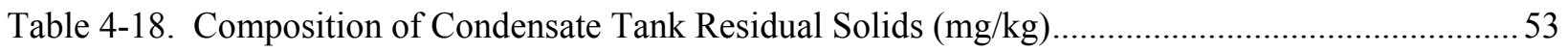




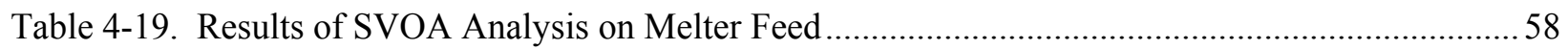

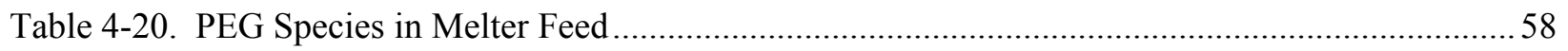

Table 4-21. Average Glass Composition (wt \%) ................................................................................. 59

Table 4-22. Comparison of Calculated and Measured Compositions (wt\%)..........................................59

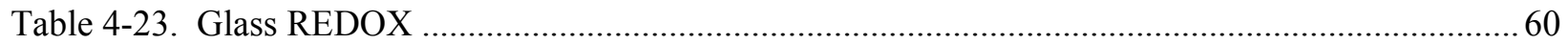

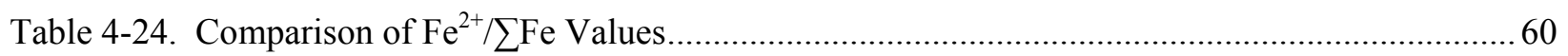

\section{LIST OF FIGURES}

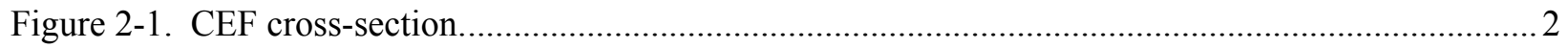

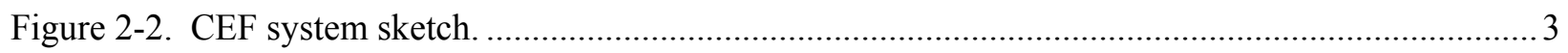

Figure 2-3. CEF camera system sketch........................................................................................ 4

Figure 2-4. Images of bubbler (a) and K3 refractory coupon (b) ........................................................ 8

Figure 4-1. $125 \%$ stoichiometry bubbled feed rate as a function of vapor space temperature. ................ 18

Figure 4-2. $125 \%$ stoichiometry bubbled condition glass production rates.......................................... 18

Figure 4-3. Cold cap images during the 125\% stoichiometry bubbled testing. ...................................... 19

Figure 4-4. Cold cap images during the $125 \%$ stoichiometry bubbled testing. ...................................... 20

Figure 4-5. $125 \%$ stoichiometry non-bubbled feed rate as a function of vapor space temperature...........22

Figure 4-6. $125 \%$ stoichiometry non-bubbled condition glass production rates.....................................22

Figure 4-7. Cold cap images during the $125 \%$ stoichiometry non-bubbled testing ................................ 23

Figure 4-8. Cold cap images during the $125 \%$ stoichiometry non-bubbled testing ............................... 24

Figure 4-9. $100 \%$ stoichiometry non-bubbled feed rate as a function of vapor space temperature...........26

Figure 4-10. 100\% stoichiometry non-bubbled condition glass production rates..................................26

Figure 4-11. Cold cap images during the $100 \%$ stoichiometry non-bubbled testing...............................2

Figure 4-12. Cold cap images during the $100 \%$ stoichiometry non-bubbled testing ..............................28

Figure 4-13. 100\% stoichiometry bubbled feed rate as a function of vapor space temperature. ............... 30

Figure 4-14. $100 \%$ stoichiometry bubbled condition glass production rates.......................................... 30

Figure 4-15. Cold cap images during the $100 \%$ stoichiometry bubbled testing. ...................................... 30

Figure 4-16. Cold cap images during the $100 \%$ stoichiometry bubbled testing. ..................................... 31 
Figure 4-17. Cold cap images during the $100 \%$ stoichiometry bubbled testing. .................................... 32

Figure 4-18. Melter pressure (PT1) before and after +16 inwc pressure surge. ....................................... 33

Figure 4-19. Images of cold cap and vent hole pre-surge (a) and during +16 inwc surge (b).................. 34

Figure 4-20. Feed rates during bubbled surge testing ......................................................................... 36

Figure 4-21. Melter pressure and hydrogen concentration during bubbled surge testing........................ 36

Figure 4-22. Image of the cold cap and vent hole prior to the +8 inwc surge. ....................................... 37

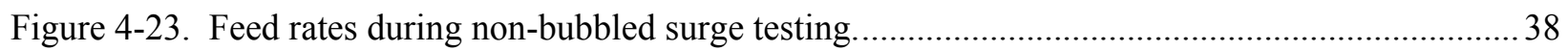

Figure 4-24. Melter pressure and hydrogen concentration during non-bubbled surge testing................... 38

Figure 4-25. Image of the cold cap prior to the +5 inwc surge during non-bubbled conditions................ 39

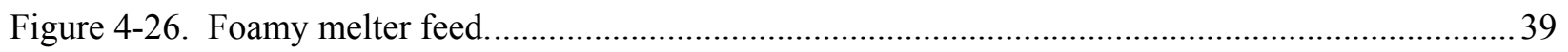

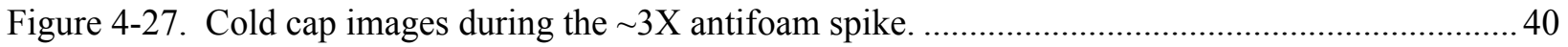

Figure $4-28$. $100 \%$ stoichiometry ( $\sim 2 \mathrm{X}$ antifoam spike) non-bubbled feed rate as a function of vapor

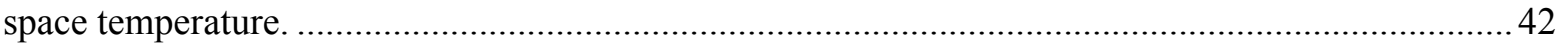

Figure 4-29. $100 \%$ stoichiometry ( $\sim 2 \mathrm{X}$ antifoam spike) non-bubbled condition glass production rates. . 42

Figure 4-30. Cold cap images during the $100 \%$ stoichiometry ( $2 \mathrm{X}$ antifoam spike) non-bubbled testing. 43

Figure 4-31. Cold cap images during the $100 \%$ stoichiometry ( $2 \mathrm{X}$ antifoam spike) non-bubbled testing. 44

Figure 4-32. Comparison of non-bubbled glass production rates (calculated) as a function of vapor space

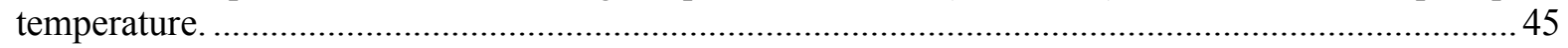

Figure 4-33. Image of lard-like material collected from a 100\% SRAT product drum...........................46

Figure 4-34. Glycolate concentration in the condensate throughout testing.......................................... 49

Figure 4-35. Glycolate, formate and TOC concentrations in the condensate. .......................................50

Figure 4-36. Comparison of anion concentrations in the condensate ....................................................51

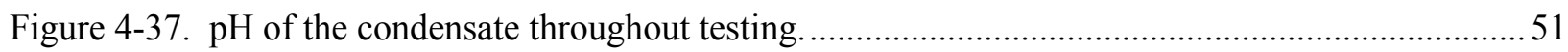

Figure 4-38. Comparison of entrainment and total argon flow throughout testing..................................52

Figure 4-39. Metal concentrations in the condensate throughout testing. ….........................................53

Figure 4-40. Metals composition in the off-gas filter solids as a function of time. .................................. 54

Figure 4-41. Comparison of Fe, Si and Li concentrations in the off-gas filter solids. Note

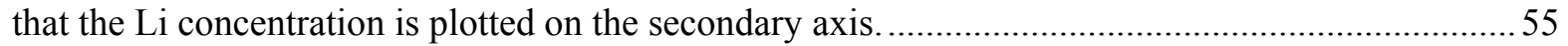

Figure 4-42. Image of typical filter solids (a) and filter solids containing flakes (b). ...........................55 
Figure 4-43. SEM image (a) and optical microscope image (b) of the iridescent flakes......................... 56

Figure 4-44. XRD spectra of typical filter solids (a) and filter solids containing flakes (b).....................57

Figure 4-45. Hydrogen generation during bubbled and non-bubbled surge testing ................................ 61 


\section{LIST OF ABBREVIATIONS}

\begin{tabular}{|c|c|}
\hline$\% \mathrm{RSD}$ & Relative Standard Deviation \\
\hline $\mathrm{AD}$ & Analytical Development \\
\hline ARP & Actinide Removal Process \\
\hline $\mathrm{CEF}$ & Cold Cap Evaluation Furnace \\
\hline CT & Computed Tomography \\
\hline DVR & Digital Video Recorder \\
\hline DWPF & Defense Waste Processing Facility \\
\hline FTIR & Fourier Transform Infrared \\
\hline $\mathrm{GC}$ & Gas Chromatograph \\
\hline HMDSO & Hexamethyl Disiloxane \\
\hline IC & Ion Chromatography \\
\hline ICP-AES & Inductively Coupled Plasma - Atomic Emission Spectroscopy \\
\hline inwe & Inches of Water Column \\
\hline $\mathrm{MCU}$ & Modular Caustic Side Solvent Extraction Unit \\
\hline MRF & Melt Rate Furnace \\
\hline MS & Mass Spectrometer \\
\hline OGCT & Off-gas Condensate Tank \\
\hline PEG & Poly(ethylene) glycol \\
\hline PSAL & Process Science Analytical Laboratory \\
\hline REDOX & REDuction/OXidation \\
\hline RPM & Rotations per Minute \\
\hline SB6 & Sludge Batch 6 \\
\hline $\operatorname{scfm}$ & Standard Cubic Feet per Minute \\
\hline SEE & Systems Engineering Evaluation \\
\hline SME & Slurry Mix Evaporator \\
\hline SMRF & Slurry Fed Melt Rate Furnace \\
\hline SRAT & Slurry Receipt and Adjustment Tank \\
\hline SRNL & Savannah River National Laboratory \\
\hline SRR & Savannah River Remediation \\
\hline SVOA & Semivolatile Organic Analysis \\
\hline TOC & Total Organic Carbon \\
\hline TTQAP & Task Technical and Quality Assurance Plan \\
\hline TTR & Technical Task Request \\
\hline UV-Vis & Ultraviolet-visible \\
\hline VSL & Vitreous State Laboratory \\
\hline WS-E & Waste Solidification Engineering \\
\hline
\end{tabular}




\subsection{Introduction}

Savannah River Remediation (SRR) conducted a Systems Engineering Evaluation (SEE) ${ }^{1}$ to determine the optimum alternate reductant flowsheet for the Defense Waste Processing Facility (DWPF). Specifically, two proposed flowsheets (nitric-formic-glycolic and nitric-formic-sugar) were evaluated based upon results from preliminary testing. ${ }^{2,3}$ Comparison of the two flowsheets among evaluation criteria indicated a preference towards the nitric-formic-glycolic flowsheet. Further research and development of this flowsheet eliminated the formic $\mathrm{acid}^{4}$, and as a result, the nitric-glycolic flowsheet was recommended for further testing.

Based on the development of a roadmap for the nitric-glycolic acid flowsheet ${ }^{5}$, Waste Solidification Engineering (WS-E) issued a Technical Task Request ${ }^{6}$ (TTR) to address flammability issues that may impact the implementation of this flowsheet. Melter testing was requested in order to define the DWPF flammability envelope for the nitric-glycolic acid flowsheet.

The Savannah River National Laboratory (SRNL) Cold Cap Evaluation Furnace (CEF), a 1/12 ${ }^{\text {th }}$ scale DWPF melter, was selected by the SRR Alternate Reductant project team as the melter platform for this testing. ${ }^{7}$ Both the CEF and DWPF melter have cylindrical cavities of the same or nearly the same diameter from the top to bottom and, therefore, their vapor space-to-melt pool cross-sectional area ratios are approximately 1.8. The melt pool aspect ratio of the CEF, which is defined as the melt pool diameterto-melt pool depth, is also practically identical to that of the DWPF melter; however, the vapor space aspect ratio of the CEF was designed at $1 / 2$ of the DWPF melter in an effort to reduce off-gas carryover under bubbled conditions.

The overall scope was divided into the following sub-tasks as discussed in the Task Technical and Quality Assurance Plan (TTQAP) ${ }^{8}$ :

- Phase I - A nitric-formic acid flowsheet melter test (unbubbled) to baseline the CEF cold cap and steady state vapor space data to the benchmark melter flammability models over a series of vapor space temperatures

- Phase II - A nitric-glycolic acid flowsheet melter test (unbubbled and bubbled) to:

o Define new cold cap reactions and global kinetic parameters for the melter flammability models

o Quantify off-gas surging potential of the feed

o Characterize off-gas condensate for complete organic and inorganic carbon species

Phase I testing and results of the data analysis and model validation were discussed in previous reports. ${ }^{9,10}$ The intent of this report is to provide a summary of the Phase II melter testing conditions that were used in support of the task objectives listed above. A compilation of sample data will also be presented. It should be noted that the interpretation and discussion of operating data and sample data for Phase II testing will be limited. A detailed analysis of the off-gas chemistry, surge potential and the flammability model development for the nitric-glycolic acid flowsheet will be addressed separately. ${ }^{11}$

\subsection{System Description}

The CEF is a 30 inch tall, 20 inch diameter Inconel ${ }^{\circledR} 690$ vessel that was fabricated at SRNL to conduct observations of cold cap behavior under a variety of melter conditions. ${ }^{12-28}$ The unit consists of 5 heating zones that are controlled separately. ${ }^{29}$ The heaters are spiral wound silicon carbide resistance heater elements that provide heat externally to the vessel. Four vapor space heaters are located inside the vessel and are surrounded by alumina tubes to protect them from the environment. A section view of the CEF is shown in Figure 2-1. The melter, along with the off-gas and condensate systems, were installed in the 
Engineering Development Laboratory (786-A). A schematic of the entire melter and off-gas system that was used to support Phase II testing is shown in Figure 2-2 and Figure 2-3. The melter is operated under a slight negative pressure (nominally -5 inches of water [inwc]), which captures the volatile components through a quencher/scrubber system. An instrumentation list for the entire system is shown in Table 2-1 through Table 2-3.

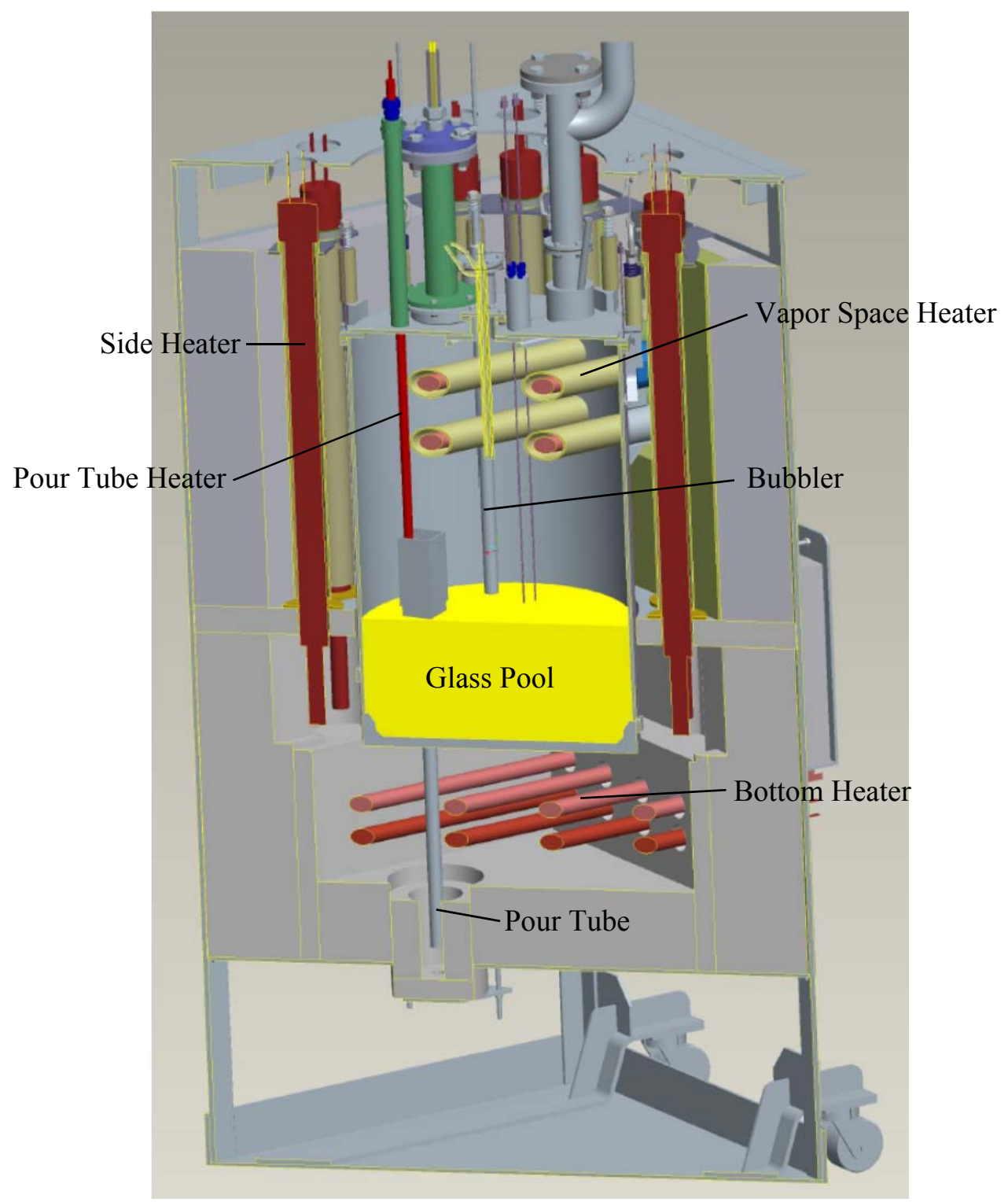

Figure 2-1. CEF cross-section. 


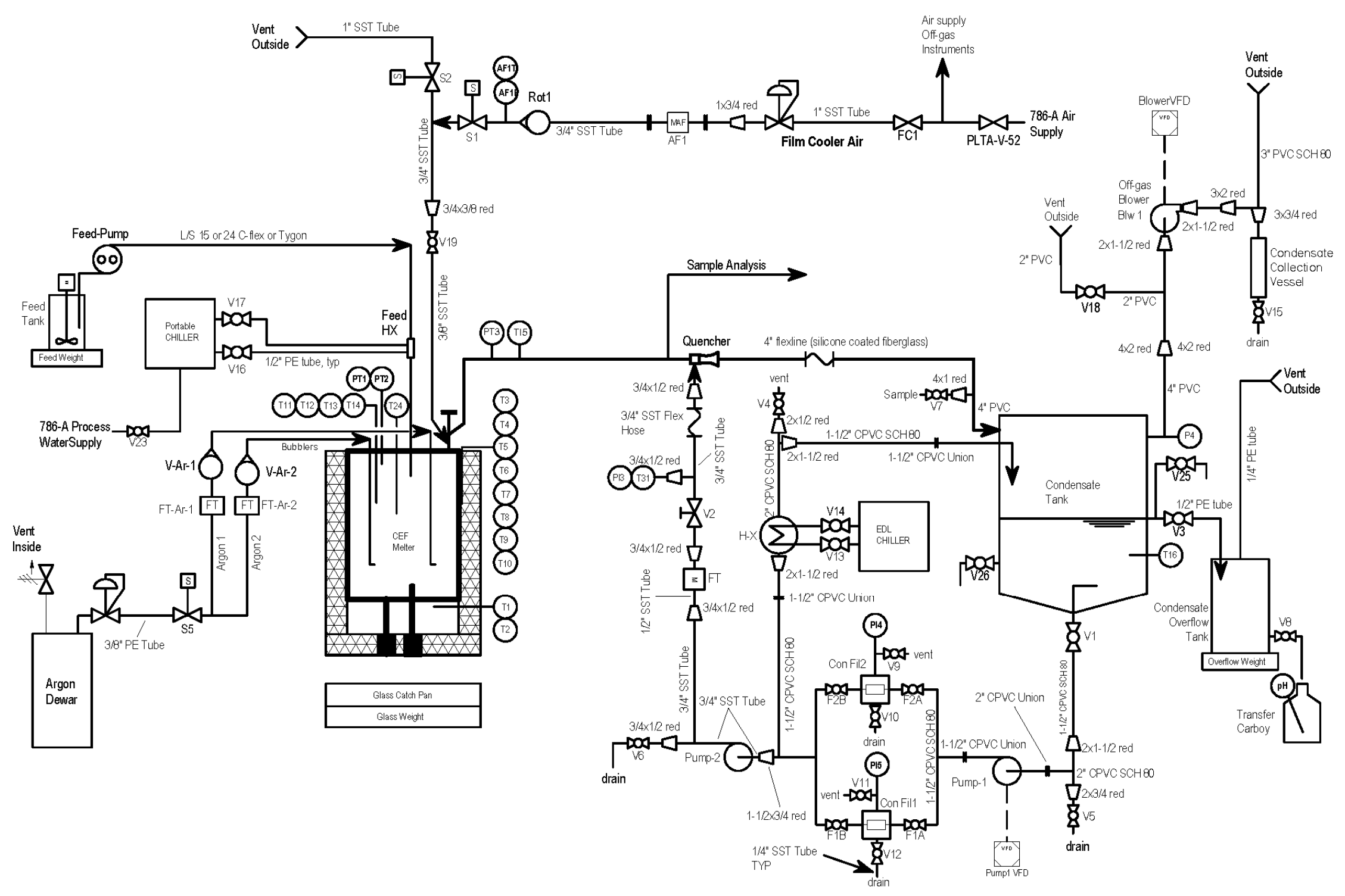

Figure 2-2. CEF system sketch. 


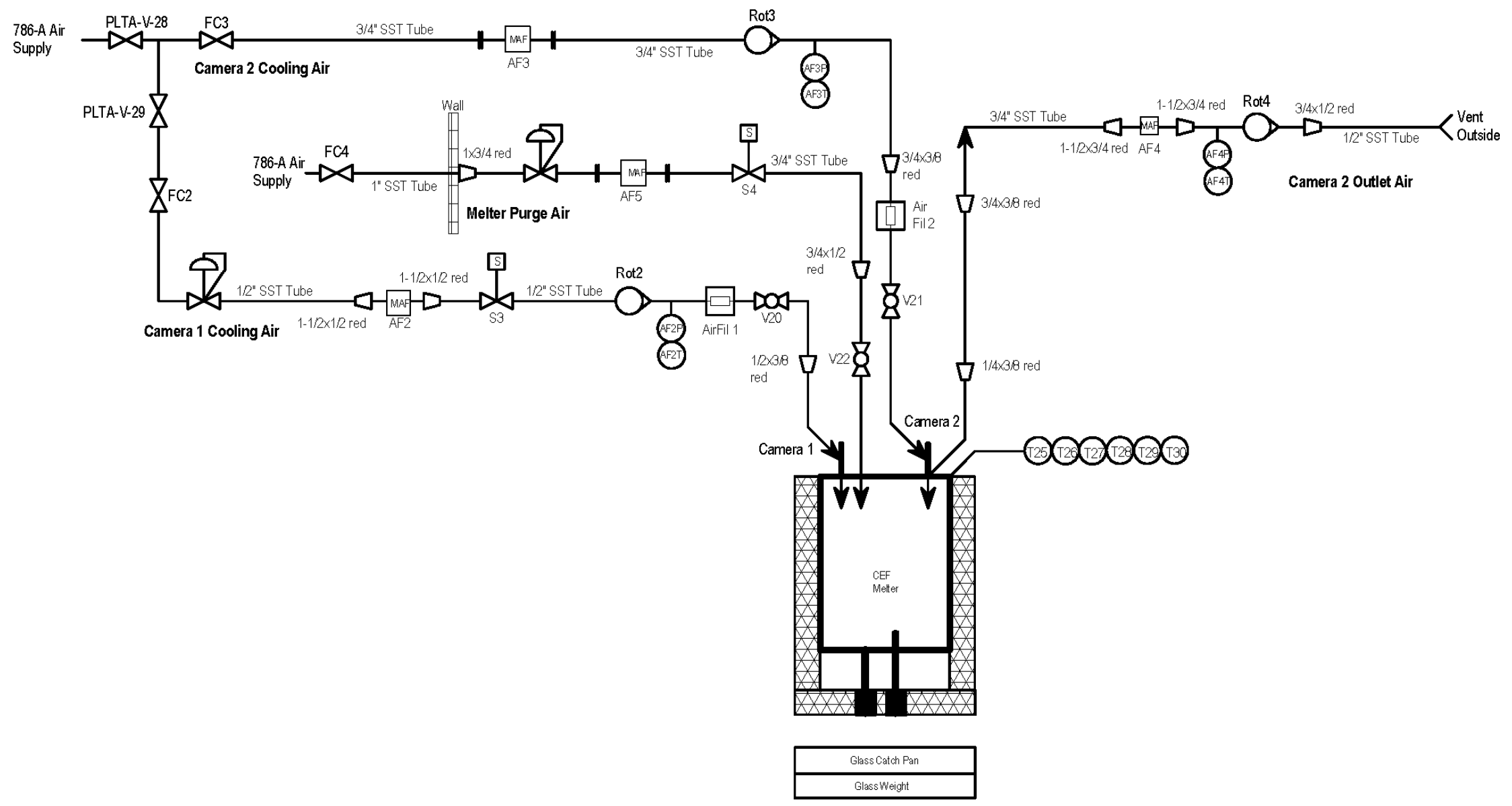

Figure 2-3. CEF camera system sketch. 
Table 2-1. Instrumentation List Set $\mathbf{1}^{\mathrm{a}}$

\begin{tabular}{|c|c|c|c|c|c|}
\hline System & Designation & Des cription & Range & Tole rance & $\begin{array}{l}\text { Ele ctronic } \\
\text { Output }\end{array}$ \\
\hline Melter & PT1 & Melter vapor space pressure 1 , transmitter & -20 to +20 in $\mathrm{H}_{2} \mathrm{O}$ & $+/-0.5 \% \mathrm{fs}$ & $4-20 \mathrm{~mA}$ \\
\hline Melter & PT2 & Melter vapor space pressure 2 , transmitter & -20 to +20 in $\mathrm{H}_{2} \mathrm{O}$ & $+/-0.5 \%$ fs & $4-20 \mathrm{~mA}$ \\
\hline Melter & V-Ar-1 & Bubbler 1 argon flow, rotameter & $0-0.7 \mathrm{scfm}$ & manuf. spec. & --- \\
\hline Melter & FT-Ar-1 & Bubbler 1 mass flow controller & $0-0.75 \mathrm{scfm}$ & $+/-(0.5 \% \mathrm{rdg}+4 \% \mathrm{fs})$ & $4-20 \mathrm{~mA}$ \\
\hline Melter & V-Ar-2 & Bubbler 2 argon flow, rotameter & $0-0.7 \mathrm{scfm}$ & manuf. spec. & --- \\
\hline Melter & FT-Ar-2 & Bubbler 2 mass flow controller & $0-0.75 \mathrm{scfm}$ & $+/-(0.5 \% \mathrm{rdg}+1.5 \% \mathrm{fs})$ & $4-20 \mathrm{~mA}$ \\
\hline Melter & T1a & Vessel bottom 1, type K T/C & -200 to $1250^{\circ} \mathrm{C}$ & $+/-2.2^{\circ} \mathrm{C}$ & -5.9 to $50.6 \mathrm{mV}$ \\
\hline Melter & $\mathrm{T} 1 \mathrm{~b}$ & Vessel bottom 1, type K T/C, spare & -200 to $1250^{\circ} \mathrm{C}$ & $+/-2.2^{\circ} \mathrm{C}$ & -5.9 to $50.6 \mathrm{mV}$ \\
\hline Melter & $\mathrm{T} 2 \mathrm{a}$ & Vessel bottom 2, type K T/C & -200 to $1250^{\circ} \mathrm{C}$ & $+/-2.2{ }^{\circ} \mathrm{C}$ & -5.9 to $50.6 \mathrm{mV}$ \\
\hline Melter & $\mathrm{T} 2 \mathrm{~b}$ & Vessel bottom 2, type K T/C, spare & -200 to $1250^{\circ} \mathrm{C}$ & $+/-2.2^{\circ} \mathrm{C}$ & -5.9 to $50.6 \mathrm{mV}$ \\
\hline Melter & $\mathrm{T} 3$ & Vessel side elev. 1A, type $\mathrm{K} \mathrm{T/C}$ & -200 to $1250^{\circ} \mathrm{C}$ & $+/-2.2^{\circ} \mathrm{C}$ & -5.9 to $50.6 \mathrm{mV}$ \\
\hline Melter & $\mathrm{T} 4$ & Vessel side elev. 1B, type K T/C & -200 to $1250^{\circ} \mathrm{C}$ & $+/-2.2^{\circ} \mathrm{C}$ & -5.9 to $50.6 \mathrm{mV}$ \\
\hline Melter & $\mathrm{T} 5$ & Vessel side elev. 2A, type K T/C & -200 to $1250^{\circ} \mathrm{C}$ & $+/-2.2^{\circ} \mathrm{C}$ & -5.9 to $50.6 \mathrm{mV}$ \\
\hline Melter & T6 & Vessel side elev. 2B, type K T/C & -200 to $1250^{\circ} \mathrm{C}$ & $+/-2.2^{\circ} \mathrm{C}$ & -5.9 to $50.6 \mathrm{mV}$ \\
\hline Melter & $\mathrm{T} 7$ & Vessel side elev. 3A, type K T/C & -200 to $1250^{\circ} \mathrm{C}$ & $+/-2.2^{\circ} \mathrm{C}$ & -5.9 to $50.6 \mathrm{mV}$ \\
\hline Melter & $\mathrm{T} 8$ & Vessel side elev. 3B, type K T/C & -200 to $1250^{\circ} \mathrm{C}$ & $+/-2.2^{\circ} \mathrm{C}$ & -5.9 to $50.6 \mathrm{mV}$ \\
\hline Melter & T9 & Vessel side elev. 4A, type K T/C & -200 to $1250^{\circ} \mathrm{C}$ & $+/-2.2^{\circ} \mathrm{C}$ & -5.9 to $50.6 \mathrm{mV}$ \\
\hline Melter & $\mathrm{T} 10$ & Vessel side elev. 4B, type K T/C & -200 to $1250^{\circ} \mathrm{C}$ & $+/-2.2^{\circ} \mathrm{C}$ & -5.9 to $50.6 \mathrm{mV}$ \\
\hline Melter & $\mathrm{T} 11$ & Vapor space 1 , type K T/C & -200 to $1250^{\circ} \mathrm{C}$ & $+/-2.2^{\circ} \mathrm{C}$ & -5.9 to $50.6 \mathrm{mV}$ \\
\hline Melter & $\mathrm{T} 12$ & Vapor space 2 , type $\mathrm{K} T / \mathrm{C}$ & -200 to $1250^{\circ} \mathrm{C}$ & $+/-2.2^{\circ} \mathrm{C}$ & -5.9 to $50.6 \mathrm{mV}$ \\
\hline Melter & $\mathrm{T} 13$ & Glass pool 1, type K T/C & -200 to $1250{ }^{\circ} \mathrm{C}$ & $+/-2.2^{\circ} \mathrm{C}$ & -5.9 to $50.6 \mathrm{mV}$ \\
\hline Melter & $\mathrm{T} 14$ & Glass pool 2, type K T/C & -200 to $1250^{\circ} \mathrm{C}$ & $+/-2.2^{\circ} \mathrm{C}$ & -5.9 to $50.6 \mathrm{mV}$ \\
\hline Melter & $\mathrm{T} 24$ & Pour tube heater, type K T/C & -200 to $1250^{\circ} \mathrm{C}$ & $+/-2.2^{\circ} \mathrm{C}$ & -5.9 to $50.6 \mathrm{mV}$ \\
\hline Melter & $\mathrm{T} 25$ & Rod Support 1, type K T/C & -200 to $1250^{\circ} \mathrm{C}$ & $+/-2.2^{\circ} \mathrm{C}$ & -5.9 to $50.6 \mathrm{mV}$ \\
\hline Melter & $\mathrm{T} 26$ & Rod Support 2, type K T/C & -200 to $1250^{\circ} \mathrm{C}$ & $+/-2.2^{\circ} \mathrm{C}$ & -5.9 to $50.6 \mathrm{mV}$ \\
\hline Melter & $\mathrm{T} 27$ & Rod Support 3, type K T/C & -200 to $1250^{\circ} \mathrm{C}$ & $+/-2.2^{\circ} \mathrm{C}$ & -5.9 to $50.6 \mathrm{mV}$ \\
\hline
\end{tabular}

${ }^{\mathrm{a}}$ Inches of water $\left(\right.$ in $\left.\mathrm{H}_{2} \mathrm{O}\right)$, percent of full scale $(\% \mathrm{fs})$, milliamps $(\mathrm{mA})$, standard cubic feet per minute (scfm), percent of reading $(\%$ rdg), thermocouple $(\mathrm{T} / \mathrm{C})$ and millivolts $(\mathrm{mV})$. 
Table 2-2. Instrumentation List Set $2^{\mathrm{b}}$

\begin{tabular}{|c|c|c|c|c|c|}
\hline System & Designation & Description & Range & Tole rance & $\begin{array}{l}\text { Electronic } \\
\text { Output }\end{array}$ \\
\hline Melter & $\mathrm{T} 28$ & Rod Support 4, type K T/C & -200 to $1250^{\circ} \mathrm{C}$ & $+/-2.2{ }^{\circ} \mathrm{C}$ & -5.9 to $50.6 \mathrm{mV}$ \\
\hline Melter & $\mathrm{T} 29$ & Rod Support 5, type K T/C & -200 to $1250^{\circ} \mathrm{C}$ & $+/-2.2{ }^{\circ} \mathrm{C}$ & -5.9 to $50.6 \mathrm{mV}$ \\
\hline Melter & $\mathrm{T} 30$ & Rod Support 6, type K T/C & -200 to $1250^{\circ} \mathrm{C}$ & $+/-2.2{ }^{\circ} \mathrm{C}$ & -5.9 to $50.6 \mathrm{mV}$ \\
\hline Melter & Glass Weight & Poured glass container platform scale & $0-30 \mathrm{Kg}$ & $+/-0.75 \% \mathrm{rdg}$ & --- \\
\hline Off-Gas & PT3 & Off-gas pressure transmitter & -20 to +20 in $\mathrm{H}_{2} \mathrm{O}$ & $+/-0.5 \%$ fs & $4-20 \mathrm{~mA}$ \\
\hline Off-Gas & $\mathrm{T} 15$ & Off-gas, type K T/C & -200 to $1250^{\circ} \mathrm{C}$ & $+/-2.2{ }^{\circ} \mathrm{C}$ & -5.9 to $50.6 \mathrm{mV}$ \\
\hline Off-Gas & $\mathrm{P} 4$ & Condensate tank pressure & 0 to +30 in $\mathrm{H}_{2} \mathrm{O}$ & manuf. spec. & --- \\
\hline Condensate & $\mathrm{P} 13$ & Quencher condensate inlet pressure gauge & 0 to $180 \mathrm{psig}$ & manuf. spec. & --- \\
\hline Condensate & FT & $\begin{array}{l}\text { Quencher condensate inlet flow } \\
\text { transmitter, } 15 \mathrm{~mm}\end{array}$ & 0 to $15 \mathrm{gpm}$ & $+/-(0.5 \% \mathrm{rdg}+1.0 \% \mathrm{fs}))$ & $4-20 \mathrm{~mA}$ \\
\hline Condensate & $\mathrm{pH}$ & Condensate overflow $\mathrm{pH}$ & manuf. spec. & manuf. spec. & --- \\
\hline Condensate & Overflow Weight & $\begin{array}{l}\text { Condensate overflow vessel platform } \\
\text { scale }\end{array}$ & $0-30 \mathrm{Kg}$ & +/- $0.75 \%$ rdg & -- \\
\hline Condensate & T31 & Quencher condensate inlet, type $\mathrm{K} \mathrm{T/C}$ & -200 to $1250^{\circ} \mathrm{C}$ & $+/-2.2{ }^{\circ} \mathrm{C}$ & -5.9 to $50.6 \mathrm{mV}$ \\
\hline Condensate & PI4 & $\begin{array}{l}\text { Condensate filter housing } 1 \text { pressure } \\
\text { gauge }\end{array}$ & 0 to $30 \mathrm{psig}$ & manuf. spec. & --- \\
\hline Condensate & PI5 & $\begin{array}{l}\text { Condensate filter housing } 2 \text { pressure } \\
\text { gauge }\end{array}$ & 0 to $30 \mathrm{psig}$ & manuf. spec. & --- \\
\hline Condensate & $\mathrm{T} 16$ & $\begin{array}{l}\text { Condensate Tank temperature, type } \mathrm{K} \\
\mathrm{T} / \mathrm{C}\end{array}$ & -200 to $1250^{\circ} \mathrm{C}$ & manuf. spec. & -5.9 to $50.6 \mathrm{mV}$ \\
\hline Feed & Feed Weight & Melter feed vessel platform scale & $0-30 \mathrm{Kg}$ & $+/-0.75 \% \mathrm{rdg}$ & --- \\
\hline Air Supply & Rot1 & Flim cooler air flow, rotameter & $0-50 \mathrm{scfm}$ & --- & --- \\
\hline Air Supply & AF1 & Flim cooler air flow, mass flow meter & $0-40 \mathrm{scfm}$ & $+/-(0.5 \% \mathrm{rdg}+2.5 \% \mathrm{fs})$ & $4-20 \mathrm{~mA}$ \\
\hline Air Supply & AF1T & Rotameter 1 temperature, type $\mathrm{K} \mathrm{T} / \mathrm{C}$ & -200 to $1250^{\circ} \mathrm{C}$ & $+/-2.2{ }^{\circ} \mathrm{C}$ & -5.9 to $50.6 \mathrm{mV}$ \\
\hline
\end{tabular}

\footnotetext{
${ }^{b}$ Inches of water (in $\left.\mathrm{H}_{2} \mathrm{O}\right)$, percent of full scale $(\% \mathrm{fs})$, milliamps $(\mathrm{mA})$, standard cubic feet per minute (scfm), percent of reading $(\%$ rdg), thermocouple $(\mathrm{T} / \mathrm{C})$ and millivolts $(\mathrm{mV})$,
} pounds per square inch gauge (psig) and gallons per minute (gpm). 
Table 2-3. Instrumentation List Set $3^{c}$

\begin{tabular}{|c|c|c|c|c|c|}
\hline System & Designation & Description & Range & Tole rance & $\begin{array}{l}\text { Electronic } \\
\text { Output }\end{array}$ \\
\hline Air Supply & AF1P & Rotameter 1 pressure, pressure gauge & $0-100$ psig & manuf. spec. & --- \\
\hline Air Supply & Rot2 & Camera 1 (Canty) air flow, rotameter & $0-25 \mathrm{scfm}$ & $+/-(0.5 \% \mathrm{rdg}+3 \% \mathrm{fs})$ & --- \\
\hline Air Supply & AF2 & $\begin{array}{l}\text { Camera } 1 \text { (Canty) air flow, mass flow } \\
\text { meter }\end{array}$ & $0-25 \mathrm{scfm}$ & $+/-(0.5 \% \mathrm{rdg}+2.5 \% \mathrm{fs})$ & $4-20 \mathrm{~mA}$ \\
\hline Air Supply & $\mathrm{AF} 2 \mathrm{~T}$ & Rotameter 2 temperature, type $\mathrm{K} \mathrm{T} / \mathrm{C}$ & -200 to $1250^{\circ} \mathrm{C}$ & $+/-2.2^{\circ} \mathrm{C}$ & -5.9 to $50.6 \mathrm{mV}$ \\
\hline Air Supply & AF2P & Rotameter 2 pressure, pressure gauge & $0-60$ psig & manuf. spec. & --- \\
\hline Air Supply & Rot3 & $\begin{array}{l}\text { Camera } 2 \text { (SRNL) inlet air flow, } \\
\text { rotameter }\end{array}$ & $0-25 \mathrm{scfm}$ & $+/-(0.5 \% \mathrm{rdg}+3 \% \mathrm{fs})$ & --- \\
\hline Air Supply & AF3 & $\begin{array}{l}\text { Camera } 2 \text { (SRNL) inlet air flow, mass } \\
\text { flow meter }\end{array}$ & $0-40 \mathrm{scfm}$ & $+/-(0.5 \% \mathrm{rdg}+2.5 \% \mathrm{fs})$ & $4-20 \mathrm{~mA}$ \\
\hline Air Supply & AF3T & Rotameter 3 temperature, type $\mathrm{K} \mathrm{T} / \mathrm{C}$ & -200 to $1250^{\circ} \mathrm{C}$ & $+/-2.2^{\circ} \mathrm{C}$ & -5.9 to $50.6 \mathrm{mV}$ \\
\hline Air Supply & AF3P & Rotameter 3 pressure, pressure gauge & $0-100$ psig & manuf. spec. & --- \\
\hline Air Supply & Rot4 & $\begin{array}{l}\text { Camera } 2 \text { (SRNL) outlet air flow, } \\
\text { rotameter }\end{array}$ & $0-25 \mathrm{scfm}$ & $+/-(0.5 \% \mathrm{rdg}+3 \% \mathrm{fs})$ & --- \\
\hline Air Supply & AF4 & $\begin{array}{l}\text { Camera } 2 \text { (SRNL) outlet air flow, mass } \\
\text { flow meter }\end{array}$ & $0-25 \mathrm{scfm}$ & $+/-(1 \% \mathrm{rdg}+5 \% \mathrm{fs})$ & $4-20 \mathrm{~mA}$ \\
\hline Air Supply & AF4T & Rotameter 4 temperature, type $\mathrm{K} \mathrm{T} / \mathrm{C}$ & -200 to $1250^{\circ} \mathrm{C}$ & $+/-2.2^{\circ} \mathrm{C}$ & -5.9 to $50.6 \mathrm{mV}$ \\
\hline Air Supply & AF4P & Rotameter 4 pressure, pressure gauge & $0-60$ psig & manuf. spec. & --- \\
\hline Air Supply & AF5 & Melter purge air flow, mass flow meter & $0-75 \mathrm{scfm}$ & $+/-(0.5 \% \mathrm{rdg}+2.5 \% \mathrm{fs})$ & $4-20 \mathrm{~mA}$ \\
\hline System & Designation & Description & Voltage & Function & Body \\
\hline Solenoids & $\mathrm{S} 1$ & Film cooler air shutoff & 110 & $\mathrm{NC}$ & brass \\
\hline Solenoids & $\mathrm{S} 2$ & Film cooler air vent & 110 & NO & brass \\
\hline Solenoids & S3 & Canty camera shutoff & 110 & NO & brass \\
\hline Solenoids & S4 & Melte stoke air shutoff & 110 & $\mathrm{NC}$ & SST \\
\hline Solenoids & S5 & Argon bubblers shutoff & 110 & $\mathrm{NC}$ & --- \\
\hline
\end{tabular}

${ }^{\mathrm{c}}$ Pounds per square inch gauge (psig), standard cubic feet per minute (scfm), percent of reading (\%rdg), percent of full scale (\%fs), milliamps (mA), millivolts (mV), normally close (NC), normally open (NO), stainless steel (SST). 


\subsection{Modifications}

Details of modifications made prior to Phase I testing are provided in the Phase I testing report. ${ }^{9}$ Prior to Phase II testing, several changes were made to the system based on experience gained during Phase I testing. Brief descriptions of the new modifications are provided below.

- The air mass flow transmitters were updated either by replacement or recalibration to a more appropriate range. These changes allowed for a higher air purge rates to be used during testing without being limited by the actual and/or calibrated range of transmitters.

- Several melter thermocouples were replaced based on wear that had occurred during Phase I testing.

- All four of the vapor space heater alumina thermowells were replaced due to cracking that had occurred after Phase I testing was completed. Four vapor space heater elements were also replaced due to breakage.

- In order to reduce air in-leakage (i) each vapor space assembly was re-packed and re-tightened, (ii) high temperature moldable alumina insulation ${ }^{\mathrm{d}}$ was also applied on the outer surface of each heater assembly, and (iii) the entire vessel top was also packed with the high temperature moldable alumina insulation.

- The exhaust blower was replaced with a regenerative blower and a variable speed drive was added so that -5 inwc could be maintained in the condensate tank during high air purge test conditions. Room temperature testing was conducted prior to heat-up to develop a performance curve for the system.

- The auxiliary pour tube rod heater was replaced. Visual inspection of the existing heater did not indicate major deterioration, but it was replaced due to the length of the planned Phase II testing campaign.

- One of the bubblers was replaced with a new unit that had a small cage welded near the bottom, into which a sample of K3 refractory was loaded. The sample was removed after Phase II testing for evaluation, the results of which will be issued in a separate report. ${ }^{30}$

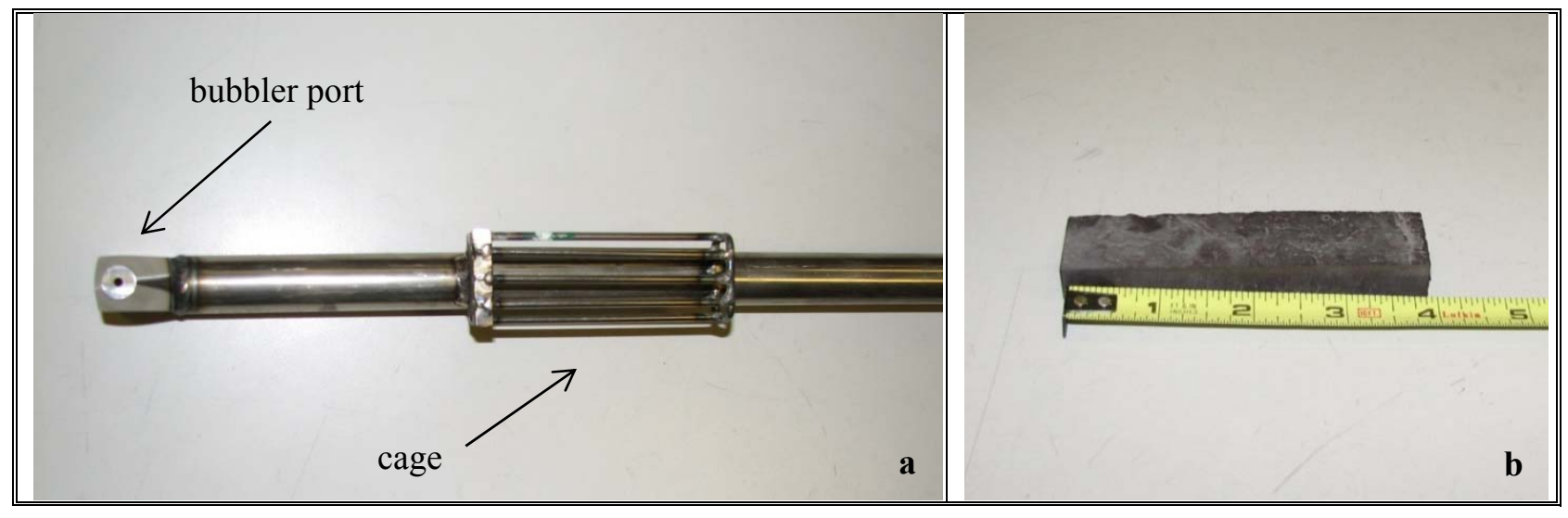

Figure 2-4. Images of bubbler (a) and $\mathrm{K3}$ refractory coupon (b).

\footnotetext{
${ }^{\mathrm{d}}$ Zircar Ceramics, Inc. Alumina Insulation Type SALI Moldable (color - light green).
} 
- The quencher was removed for visual inspection. A flush of the quencher was also performed prior to re-assembly to clear out any particulate that had built up during Phase I testing.

- The camera designed at SRNL (Camera 2) was removed since it was no longer in focus. Breaches in the bellows assembly were repaired and the camera was replaced with a fixed focal length.

During Phase II testing, it was necessary to make several additional modifications as described below.

- A metal crossbar was placed on the top of the off-gas condensate tank (OGCT) to support the Lexan cover, which allowed operation at higher vacuum conditions.

- The regenerative blower was replaced after failure during surge testing and a 55-gallon poly drum was installed before the blower to capture condensate and extend the life of the blower.

- One of the stainless steel transition pieces in the feed line was re-designed to have a $45^{\circ}$ instead of a $90^{\circ}$ angle in order to reduce the possibility of a feed blockage. The new piece was also machined and de-burred to remove any internal edges that could cause a buildup of feed.

- A peristaltic pump was added to the condensate sample collection valve on the OGCT so that condensate samples could be collected at lower vapor space temperatures when the air purge was utilized.

\subsection{Experimental Procedure}

\subsection{Quality Assurance}

Requirements for performing reviews of technical reports and the extent of review are established in manual E7 2.60. SRNL documents the extent and type of review using the SRNL Technical Report Design Checklist contained in WSRC-IM-2002-00011, Rev. 2.

\subsection{Melter Feed}

The processing strategy for the Sludge Receipt and Adjustment Tank (SRAT) product runs was developed by SRNL to prepare melter feeds that meet the following guidelines. ${ }^{31,32}$

- Nitric-glycolic acid flowsheet at $100 \%$ and $125 \%$ Koopman $^{33}$ acid stoichiometry

- No noble metals or mercury ${ }^{34}$

- $\mathrm{Fe}^{2+} / \sum \mathrm{Fe}$ between 0.10 and 0.25 ; the higher end of this range is desired

- Yield stress $<25 \mathrm{~Pa}$

- Total solids after frit addition: 42 to $50 \mathrm{wt} \%$

- Antifoam added: $2000 \mathrm{mg} / \mathrm{kg}$ on a carbon basis

- Abbreviated SRAT cycle (compared to typical DWPF processing), no Slurry Mix Evaporator (SME) cycle $^{35}$

- No Actinide Removal Process (ARP) or Modular Caustic Side Solvent Extraction Unit (MCU) material added (sludge only)

The Sludge Batch 6 (SB6I) simulant was produced by BlueGrass Chemical Specialties, LLC and was processed into SRAT product by abbreviated SRAT cycles at Harrell Industries, Inc. in June, July and August 2013. e,f $^{\text {S }}$ Samples of the $100 \%$ and $125 \%$ SRAT products were analyzed by SRNL for verification

\footnotetext{
${ }^{\mathrm{e}}$ The SB6I simulant was produced by BlueGrass Chemical Specialties, LLC of New Albany, IN.
} 
prior to shipment (Table 3-1 through Table 3-4) and memos recommending acceptance of these batches were issued. ${ }^{36,37}$ The SRAT products were transferred into 30 -gallon poly drums at Harrell Industries and shipped to SRNL in July and August 2013.

Table 3-1. Physical Properties of the Harrell SB6I 100\% and 125\% SRAT Products ${ }^{\mathrm{g}}$

\begin{tabular}{llll}
\hline Prope rty & $\begin{array}{l}\mathbf{1 0 0 \%} \text { SB6I } \\
\text { SRAT Product }\end{array}$ & $\begin{array}{l}\mathbf{1 2 5 \%} \text { SB6I } \\
\text { SRAT Product }\end{array}$ & Units \\
\hline Total Solids & 32.3 & 32.8 & weight \% \\
\hline Insoluble Solids & 15.8 & 15.7 & weight \% \\
\hline Soluble Solids & 16.5 & 17.1 & weight $\%$ \\
\hline Calcine Solids & 18.0 & 17.7 & weight $\%$ \\
\hline Slurry Density & 1.2514 & 1.2553 & $\mathrm{~g} / \mathrm{mL}$ at $25^{\circ} \mathrm{C}$ \\
\hline Supernate Density & 1.134 & 1.1526 & $\mathrm{~g} / \mathrm{mL}$ at $25^{\circ} \mathrm{C}$ \\
\hline pH & 5.03 & 3.21 & \\
\hline Yield Stress & 0.76 & 4.9 & $\mathrm{~Pa}$ \\
\hline Consistency & 5.44 & 15.2 & $\mathrm{cP}$ \\
\hline
\end{tabular}

Table 3-2. Harrell SB6I SRAT Product Compositions (wt\% calcine solids basis)

\begin{tabular}{ccc}
\hline Element & $\begin{array}{c}\mathbf{1 0 0 \%} \text { SB6I } \\
\text { SRAT Product }\end{array}$ & $\begin{array}{c}\mathbf{1 2 5 \%} \text { SB6I } \\
\text { SRAT Product }\end{array}$ \\
\hline $\mathrm{Al}$ & 13.6 & 13.6 \\
$\mathrm{Ba}$ & 0.148 & 0.112 \\
$\mathrm{Ca}$ & 1.30 & 1.27 \\
$\mathrm{Cr}$ & 0.20 & 0.18 \\
\hline $\mathrm{Cu}$ & 0.119 & 0.104 \\
\hline $\mathrm{Fe}$ & 23.1 & 22.0 \\
\hline $\mathrm{K}$ & 0.090 & 0.097 \\
\hline $\mathrm{Mg}$ & 0.65 & 0.71 \\
\hline $\mathrm{Mn}$ & 7.4 & 6.73 \\
\hline $\mathrm{Na}$ & 12.9 & 14.2 \\
\hline $\mathrm{Ni}$ & 2.88 & 3.09 \\
\hline $\mathrm{P}$ & 0.090 & Not Measured \\
\hline $\mathrm{Si}$ & 1.40 & 1.15 \\
\hline $\mathrm{Ti}$ & 0.03 & 0.035 \\
\hline $\mathrm{Zn}$ & 0.114 & 0.111 \\
\hline $\mathrm{Zr}$ & 0.30 & 0.28 \\
\hline
\end{tabular}

Table 3-3. Harrell SB6I SRAT Product Supernate Compositions (mg/L)

\begin{tabular}{ccc}
\hline Element & $\mathbf{1 0 0 \%}$ SB6I & $\mathbf{1 2 5 \%}$ SB6I \\
\hline $\mathrm{Al}$ & 349 & 1100 \\
$\mathrm{Ba}$ & 1.72 & 3.46 \\
$\mathrm{Ca}$ & 2,650 & 3,140 \\
$\mathrm{Cr}$ & 1.54 & 4.35 \\
\hline $\mathrm{Cu}$ & 56.1 & 183 \\
\hline $\mathrm{Fe}$ & 305 & 2,700 \\
\hline $\mathrm{K}$ & 894 & 1,070 \\
\hline $\mathrm{Mg}$ & 2,020 & 2,350 \\
\hline $\mathrm{Mn}$ & 14,600 & 13,600 \\
\hline $\mathrm{Na}$ & 31,900 & 34,000 \\
\hline $\mathrm{Ni}$ & 2,720 & 5,350 \\
\hline $\mathrm{P}$ & $<10.0$ & 18.6 \\
\hline $\mathrm{S}$ & 818 & 766 \\
\hline $\mathrm{Si}$ & 707 & 298 \\
\hline $\mathrm{Sn}$ & 9.51 & 6.23 \\
\hline $\mathrm{Ti}$ & 0.323 & 3.53 \\
\hline $\mathrm{Zn}$ & 55.7 & 144 \\
\hline $\mathrm{Zr}$ & $<0.100$ & 0.100 \\
\hline
\end{tabular}

\footnotetext{
${ }^{\mathrm{f}}$ The SB6I SRAT product was produced by Harrell Industries, Inc. of Rock Hill, SC.

${ }^{\mathrm{g}}$ Pascal $(\mathrm{Pa})$ and centipoise $(\mathrm{cP})$.
} 
Table 3-4. Harrell SB6I SRAT Products Anions and TOC (mg/kg)

\begin{tabular}{lcc}
\hline Species & $\mathbf{1 0 0 \%}$ SB6I & $\mathbf{1 2 5 \%}$ SB6I \\
\hline $\mathrm{F}$ & $<500$ & $<500$ \\
$\mathrm{Cl}$ & 417 & $<500$ \\
$\mathrm{NO}_{2}$ & $<500$ & $<500$ \\
\hline $\mathrm{NO}_{3}$ & 67,000 & 84,900 \\
$\mathrm{C}_{2} \mathrm{H}_{3} \mathrm{O}_{3}$ & 44,500 & 43,500 \\
$\mathrm{SO}_{4}$ & 1,860 & 2,700 \\
\hline $\mathrm{C}_{2} \mathrm{O}_{4}$ & 2,010 & 2,160 \\
$\mathrm{HCO}_{2}$ & 3,140 & $<500$ \\
\hline $\mathrm{PO}_{4}$ & $<500$ & $<500$ \\
\hline $\mathrm{TOC}$ & 12,500 & 23,300 \\
\hline
\end{tabular}

It should be noted that the measured REDOX via the sealed crucible method did not meet the $\mathrm{Fe}^{2+} / \sum \mathrm{Fe}$ targets for either of these as-received SRAT products as part of the acceptance criteria. The target REDOX for the $100 \%$ stoichiometry melter feed was $0.15 \mathrm{Fe}^{2+} / \sum \mathrm{Fe}$, while the measured REDOX was 0.47 . The target REDOX for the $125 \%$ stoichiometry melter feed was $0.2-0.3 \mathrm{Fe}^{2+} / \sum \mathrm{Fe}$, while the measured REDOX was $<0.02$. While the SRAT products were acceptable for shipment to SRNL, it was recommended that (i) the melter feed based on the $125 \%$ stoichiometry SRAT product be remediated with glycolic acid at SRNL, and (ii) the melter feed based on the $100 \%$ stoichiometry SRAT product be remediated with nitric acid at SRNL. Additional sealed crucible REDOX testing was performed to remediate the melter feed with nitric acid for the 100\% SRAT product and glycolic acid for the $125 \%$ SRAT product. A series of melter feed samples were prepared with a range of acid concentrations (low, medium and high) for each of the SRAT products to obtain a REDOX response curve, the results of which are shown in Table 3-5. . $^{\text {,38,39 }}$ Based on these results the "low" nitric acid concentration was selected for the $100 \%$ melter feed and a blend point interpolated between the "low" and "medium" glycolic acid concentrations was selected for the $125 \%$ melter feed.

Table 3-5. Remediation REDOX Results

\begin{tabular}{|c|c|c|c|c|}
\hline Melter Feed & Acid & Sample & Target $\mathrm{Fe}^{2+} / \sum \mathrm{Fe}$ & Average $\mathrm{Fe}^{2+} / \sum \mathrm{Fe}$ \\
\hline \multirow{4}{*}{$100 \%$} & --- & as-received & 0.15 & 0.47 \\
\hline & nitric & low & \multirow{3}{*}{0.25} & 0.25 \\
\hline & nitric & medium & & All Fe ${ }^{3+}$ \\
\hline & nitric & high & & All Fe ${ }^{3+}$ \\
\hline \multirow{4}{*}{$125 \%$} & --- & as-received & $0.2-0.3$ & All Fe $e^{3+}$ \\
\hline & glycolic & low & \multirow{3}{*}{0.35} & 0.10 \\
\hline & glycolic & medium & & 0.48 \\
\hline & glycolic & high & & 0.58 \\
\hline
\end{tabular}

\footnotetext{
${ }^{\mathrm{h}}$ The target $\mathrm{Fe}^{2+} / \sum \mathrm{Fe}$ was selected to be 0.1 higher than initial targets due to oxidation in the CEF that was observed in Phase I
} CEF testing. 
Six different melter feeds were used to generate off-gas flammability data (vapor space steady state testing) and surge potential data in support of the task objectives. The melter feed used for the CEF testing was produced by combining the Harrell Industries SB6I SRAT product with dry Frit 418 at a target waste loading of 36\% and nitric or glycolic acid to adjust the REDOX (Table 3-6). Depending on the testing conditions additional water was added to yield a total solids content of either $\sim 45 \mathrm{wt} \%$ or $\sim 42$ $\mathrm{wt} \%$ in order to facilitate feeding. Note that there were issues with the $125 \%$ stoichiometry melter feed at $49 \mathrm{wt} \%$ and the total solids was further reduced to $45 \mathrm{wt} \%$. There were also difficulties in achieving steady state conditions with the $100 \%$ stoichiometry melter feed spiked with approximately three times the nominal amount $(\sim 3 \mathrm{X})$ and the antifoam spike was reduced to two times the nominal amount $(\sim 2 \mathrm{X})$.

Table 3-6. Remediation of Harrell SRAT Product (kg/30-gallon drum)

\begin{tabular}{lcccccc}
\hline \multirow{2}{*}{ Melter Feed } & \multicolumn{2}{c}{$\mathbf{1 0 0 \%}$} & $\begin{array}{c}\mathbf{1 0 0 \%} \\
\sim 3 X \text { Antifoam } \\
\text { Spike }\end{array}$ & $\begin{array}{c}\mathbf{1 0 0 \%} \\
\sim 2 \text { Xntifoam } \\
\text { Spike }\end{array}$ & \multicolumn{2}{c}{$\mathbf{1 2 5 \%}$} \\
\hline Objective & Surge & $\begin{array}{c}\text { Steady } \\
\text { State }\end{array}$ & Steady State & Steady State & $\begin{array}{c}\text { Steady } \\
\text { State }\end{array}$ & $\begin{array}{c}\text { Steady } \\
\text { State }\end{array}$ \\
\hline Total Solids (\%) & $\mathbf{4 2}$ & $\mathbf{4 5}$ & $\mathbf{4 5}$ & $\mathbf{4 5}$ & $\mathbf{4 9}$ & $\mathbf{4 5}$ \\
\hline Glycolic Acid & --- & --- & --- & --- & 1.5 & 1.5 \\
\hline Nitric Acid & 2 & 2 & 2 & 2 & --- & --- \\
\hline Water & 19.7 & 8.4 & 8.4 & 8.4 & --- & 10.5 \\
\hline Antifoam 747 & --- & --- & 0.7 & 0.4 & --- & -- \\
\hline
\end{tabular}

\subsection{Startup Cullet}

The melter was loaded with $\sim 105 \mathrm{~kg}$ of SB6-Frit 418 startup cullet (36\% waste loading) that was produced during the 2013 Phase I CEF testing and its level in the vessel was approximately 17-19" from the site port seal surface. ${ }^{9}$ This glass was chosen since it was the same composition to the CEF Phase II melter feed, thus reducing the quantity of feed required for the test and the time involved to reach steady state conditions.

\subsection{Post-Run Sample Analysis}

\subsubsection{Weight Percent Solids}

Total, dissolved and/or calcined solids were measured by the Process Science Analytical Laboratory (PSAL) for the melter feed, filter solids and condensate samples per procedure. ${ }^{40}$

\subsubsection{Composition Measurements}

Melter feed, off-gas condensate system bag filter solids and glass samples were prepared by PSAL using the following fusions: sodium peroxide/sodium hydroxide ${ }^{41}$, lithium metaborate ${ }^{42}$ and lithium tetraborate/lithium nitrate ${ }^{43}$ and aqua regia ${ }^{44}$ for cations and potassium hydroxide ${ }^{45}$ and for anions. Cations were measured with Inductively Coupled Plasma - Atomic Emission Spectroscopy (ICP-AES) and anions were measured with Ion Chromatography (IC). ${ }^{46,47}$ Melter feed anions were also measured by the SRNL Analytical Laboratory (AD) per procedure. ${ }^{48}$ Total organic carbon (TOC) content of the melter feed and condensate samples were measured by the DWPF laboratory. ${ }^{49}$ Semi volatile organic analysis (SVOA) was measured by AD per procedure on the sorbent tubes containing coconut charcoal that were placed in the off-gas line prior to the analyzers. ${ }^{50}$ 


\subsubsection{Reduction/Oxidation (REDOX) Measurements}

Triplicate samples of remediated melter feed were prepared according to the sealed crucible method. ${ }^{38}$ Additional samples were prepared by heating melter feed in a quartz crucible under a flowing argon atmosphere. ${ }^{\mathrm{i}, 51}$ The resulting glass samples, as well as glass samples collected directly from the pour stream during CEF Phase II testing were crushed, dissolved and analyzed by PSAL via UltravioletVisible (UV-Vis) spectroscopy according to procedure. ${ }^{39}$

\subsection{Results and Discussion}

Multiple vapor space temperatures in the range of $\sim 250-750^{\circ} \mathrm{C}$ were evaluated during various test conditions in order to generate off-gas data in support of the melter flammability model development. A summary of the test conditions is shown in Table 4-1. Note that the vapor space temperature targets were only approximations of temperatures that could actually be achieved during melter testing. Two different acid stoichiometries (100\% and 125\%) were used so that there would be additional data for the off-gas flammability model development. An acid stoichiometry of $100 \%$ is more prototypical of the expected stoichiometry to be recommended during nitric-glycolic flowsheet processing at DWPF. The antifoam spike test was performed in order to (i) better understand how antifoam degrades in the cold cap by comparing the resulting off-gas profiles of $\mathrm{CO}$ and $\mathrm{H}_{2}$ to those of the baseline case, and (ii) evaluate the antifoam decomposition scheme used in the current off-gas flammability model. Bubbling was not needed to evaluate the antifoam degradation products.

Table 4-1. Summary of the Vapor Space Temperature Steady State Testing Conditions

\begin{tabular}{|c|c|c|}
\hline Acid Stoichiometry & Condition & $\begin{array}{ll}\text { Vapor Space } & \text { Temperature } \\
\text { Targets }\left({ }^{\circ} \mathbf{C}\right) & \\
\end{array}$ \\
\hline $125 \%$ & bubbled and non-bubbled & $\begin{array}{l}<300^{\circ} \mathrm{C}, 350^{\circ} \mathrm{C}, 400^{\circ} \mathrm{C}, 500^{\circ} \mathrm{C}, \\
600^{\circ} \mathrm{C} \text { and } 700^{\circ} \mathrm{C}\end{array}$ \\
\hline $100 \%$ & bubbled and non-bubbled & $\begin{array}{l}<300^{\circ} \mathrm{C}, 350^{\circ} \mathrm{C}, 400^{\circ} \mathrm{C}, 500^{\circ} \mathrm{C}, \\
600^{\circ} \mathrm{C} \text { and } 700^{\circ} \mathrm{C}\end{array}$ \\
\hline $100 \%$ with $\sim 2 \mathrm{X}$ antifoam spike & non-bubbled & $\begin{array}{l}<300^{\circ} \mathrm{C}, 350^{\circ} \mathrm{C}, 400^{\circ} \mathrm{C}, 500^{\circ} \mathrm{C}, \\
600^{\circ} \mathrm{C} \text { and } 700^{\circ} \mathrm{C}\end{array}$ \\
\hline
\end{tabular}

During these tests it was desired to maintain consistent cold cap coverage and steady state conditions while collecting off-gas data for approximately two hours at each target vapor space temperature. Steady state was defined by the following three parameters:

- Vapor space temperature $\left( \pm 25^{\circ} \mathrm{C}\right)$

- Feed rate

- Off-gas readings $\left(\mathrm{H}_{2}, \mathrm{CO}_{2}\right.$ and $\left.\mathrm{NO}_{\mathrm{x}}\right)$

A combination of feed rate, heater output and air flow adjustments were necessary to achieve the various vapor space temperatures. In some cases, several hours were required to achieve steady state conditions. As the vapor space temperature was reduced, feed rate reductions were required to prevent overfeeding of the melter. Deviations in the melt pool thermocouple temperatures (T13 and T14) were an indicator of overfeeding, but there was a substantial delay between overfeeding and the subsequent temperature deviation, which prolonged the time necessary to reach steady state conditions. Underfeeding of the melter was characterized by a cold cap that was light in color and/or cracked. It was desired to have approximately $90 \%$ cold cap coverage with the presence of some vent holes without overfeeding or underfeeding the melter.

\footnotetext{
${ }^{\mathrm{i}}$ More details of the experimental setup is provided in SRNL-STI-2014-00286.
} 
Surge testing was performed in order to collect off-gas surge potential data in terms of melter pressure and off-gas compositional spikes while operating the melter at a nominal vapor space temperature in the range of $700-750^{\circ} \mathrm{C}$. A summary of the test conditions is shown in Table $4-2$. Again the $100 \%$ stoichiometry melter feed was selected for the surge testing as this stoichiometry is closer to the stoichiometry expected to be recommended for DWPF operation based on chemical process cell (CPC) testing performed to date.

Table 4-2. Summary of the Surge Testing Conditions

\begin{tabular}{lll}
\hline Acid Stoichiometry & Condition & $\begin{array}{l}\text { Vapor Space } \\
\text { Target }\left({ }^{\circ} \mathbf{C}\right)\end{array}$ \\
\hline $100 \%$ & bubbled and non-bubbled & nominal $\left(700-750^{\circ} \mathrm{C}\right)$ \\
\hline
\end{tabular}

More details of these tests will be provided in the following Sections 4.3 through 4.5. Dates and approximate times for the various conditions and tests are provided for reference in Table 4-3 and Table 4-4. It should be noted that a discussion of the off-gas data and the flammability model development is provided in a separate report. ${ }^{11}$

All raw data collected by the data acquisition system every 30 seconds throughout testing is available in SRNL-L3100-2014-00081. ${ }^{52}$ Plots of data collected throughout testing are shown in the Appendix Figure A-1 through Figure A-50 and include:

- Bottom and side thermocouple temperatures

- Vapor space and glass pool thermocouple temperatures

- Air flows and argon bubbler flows

- Vapor space and off-gas line pressures

- Heater outputs

- Feed rate

- Support block thermocouple temperatures

\subsection{Melter Heat-up}

The melter was energized on February 24, 2014 at approximately 11:36 and the bottom and side heaters were ramped to $\sim 125^{\circ} \mathrm{C}$ in approximately 11.5 hours. Vapor space heaters were ramped slowly in manual mode, which resulted in a vapor space temperature of $\sim 860^{\circ} \mathrm{C}$. ${ }^{j}$ The side and bottom heaters were operated in manual mode until the temperature approached the target temperature of $1125^{\circ} \mathrm{C}$, at which point automatic mode was used. The pour heater and auxiliary pour tube rod heater were controlled in manual mode as needed to facilitate pouring of the cullet once melting had occurred. Standard air flows were used during the time required for heat-up. ${ }^{\mathrm{k}}$ Just prior to feeding, the melt pool temperature had reached an average temperature of $1040^{\circ} \mathrm{C}$.

\footnotetext{
${ }^{\mathrm{j}}$ An attempt was made to heat the vapor space heaters at no more than $2.5^{\circ} \mathrm{C} / \mathrm{min}$ in order to protect the integrity of the alumina tubes surrounding the vapor space heater elements; however, the automatic heater control ramp rate was not precise and it was necessary to use manual control.

${ }^{\mathrm{k}} 16 \mathrm{scfm}$ (AF1 - film cooler), $8 \mathrm{scfm}$ (AF2 - camera 1), $8 \mathrm{scfm}$ (AF3 - camera 2 inlet), $7 \mathrm{scfm}$ (AF4 - camera 2 outlet) and 0 scfm (AF5 - melter stoke air). Note that these are approximate values.
} 
Table 4-3. Test Conditions, Dates and Approximate Times Set 1

\begin{tabular}{|c|c|c|c|c|c|c|c|}
\hline $\begin{array}{c}\text { Feed } \\
\text { Stoichiometry }\end{array}$ & $\begin{array}{c}\text { Total Solids } \\
\text { Target }\end{array}$ & $\begin{array}{c}\text { Antifoam } \\
\text { Target }\end{array}$ & $\begin{array}{c}\text { Ave rage } \\
\text { Bubbling } \\
\text { Rate }\end{array}$ & $\begin{array}{c}\text { Average Vapor } \\
\text { Space } \\
\text { Tempe rature }\end{array}$ & Condition & Start Date/Time & End Date/Time \\
\hline $125 \%$ & $49 \%$ & nominal & --- & --- & --- & $2 / 24 / 201422: 55$ & $2 / 26 / 201416: 39$ \\
\hline $125 \%$ & $45 \%$ & nominal & $0.2 \mathrm{scfm}$ & $705^{\circ} \mathrm{C}$ & steady state & $2 / 26 / 201420: 28$ & 2/26/2014 22:28 \\
\hline $125 \%$ & $45 \%$ & nominal & $0.2 \mathrm{scfm}$ & $625^{\circ} \mathrm{C}$ & steady state & 2/27/2014 5:15 & $2 / 27 / 20147: 15$ \\
\hline $125 \%$ & $45 \%$ & nominal & $0.2 \mathrm{scfm}$ & $481^{\circ} \mathrm{C}$ & steady state & $2 / 27 / 201413: 20$ & $2 / 27 / 201415: 20$ \\
\hline $125 \%$ & $45 \%$ & nominal & $0.2 \mathrm{scfm}$ & $405^{\circ} \mathrm{C}$ & steady state & $2 / 28 / 20141: 05$ & 2/28/2014 3:59 \\
\hline $125 \%$ & $45 \%$ & nominal & $0.2 \mathrm{scfm}$ & $358^{\circ} \mathrm{C}$ & steady state & $2 / 28 / 20148: 40$ & $2 / 28 / 201411: 42$ \\
\hline $125 \%$ & $45 \%$ & nominal & $0.1 \mathrm{scfm}$ & $271^{\circ} \mathrm{C}$ & steady state & $2 / 28 / 2014$ 14:45 & $2 / 28 / 201416: 47$ \\
\hline $125 \%$ & $45 \%$ & nominal & $0.002 \mathrm{scfm}$ & $309^{\circ} \mathrm{C}$ & steady state & 2/28/2014 21:54 & 3/1/2014 0:00 \\
\hline $125 \%$ & $45 \%$ & nominal & $0.002 \mathrm{scfm}$ & $351^{\circ} \mathrm{C}$ & steady state & $3 / 1 / 20144: 11$ & $3 / 1 / 20146: 32$ \\
\hline $125 \%$ & $45 \%$ & nominal & $0.002 \mathrm{scfm}$ & $393^{\circ} \mathrm{C}$ & steady state & 3/1/2014 10:19 & 3/1/2014 13:30 \\
\hline $125 \%$ & $45 \%$ & nominal & $0.002 \mathrm{scfm}$ & $709^{\circ} \mathrm{C}$ & steady state & $3 / 2 / 20144: 40$ & $3 / 2 / 20146: 40$ \\
\hline $100 \%$ & $45 \%$ & nominal & $0.001 \mathrm{scfm}$ & $697^{\circ} \mathrm{C}$ & steady state & $3 / 2 / 201416: 20$ & $3 / 2 / 2014$ 18:20 \\
\hline $100 \%$ & $45 \%$ & nominal & $0.002 \mathrm{scfm}$ & $600^{\circ} \mathrm{C}$ & steady state & $3 / 2 / 201421: 10$ & $3 / 2 / 201423: 10$ \\
\hline $100 \%$ & $45 \%$ & nominal & $0.003 \mathrm{scfm}$ & $496^{\circ} \mathrm{C}$ & steady state & $3 / 3 / 20143: 13$ & $3 / 3 / 20145: 13$ \\
\hline $100 \%$ & $45 \%$ & nominal & $0.003 \mathrm{scfm}$ & $410^{\circ} \mathrm{C}$ & steady state & $3 / 3 / 20148: 30$ & $3 / 3 / 2014$ 11:10 \\
\hline $100 \%$ & $45 \%$ & nominal & $0.002 \mathrm{scfm}$ & $344^{\circ} \mathrm{C}$ & steady state & $3 / 4 / 20140: 12$ & $3 / 4 / 20142: 12$ \\
\hline $100 \%$ & $45 \%$ & nominal & $0.002 \mathrm{scfm}$ & $326^{\circ} \mathrm{C}$ & steady state & $3 / 4 / 20144: 05$ & $3 / 4 / 20146: 05$ \\
\hline $100 \%$ & $45 \%$ & nominal & $0.2 \mathrm{scfm}$ & $323^{\circ} \mathrm{C}$ & steady state & $3 / 4 / 201420: 24$ & $3 / 4 / 201422: 24$ \\
\hline $100 \%$ & $45 \%$ & nominal & $0.2 \mathrm{scfm}$ & $373^{\circ} \mathrm{C}$ & steady state & $3 / 5 / 20147: 30$ & $3 / 5 / 20149: 30$ \\
\hline $100 \%$ & $45 \%$ & nominal & $0.2 \mathrm{scfm}$ & $471^{\circ} \mathrm{C}$ & steady state & $3 / 6 / 20140: 45$ & $3 / 6 / 20142: 45$ \\
\hline $100 \%$ & $45 \%$ & nominal & $0.2 \mathrm{scfm}$ & $521^{\circ} \mathrm{C}$ & steady state & $3 / 6 / 20143: 25$ & $3 / 6 / 20145: 00$ \\
\hline $100 \%$ & $45 \%$ & nominal & $0.2 \mathrm{scfm}$ & $607^{\circ} \mathrm{C}$ & steady state & 3/7/2014 17:00 & 3/7/2014 19:00 \\
\hline $100 \%$ & $45 \%$ & nominal & $0.2 \mathrm{scfm}$ & $705^{\circ} \mathrm{C}$ & steady state & $3 / 8 / 20141: 45$ & $3 / 8 / 20143: 45$ \\
\hline $100 \%$ & $45 \%$ & nominal & $0.2 \mathrm{scfm}$ & $750^{\circ} \mathrm{C}$ & steady state & $3 / 8 / 20146: 00$ & $3 / 8 / 20148: 30$ \\
\hline
\end{tabular}


Table 4-4. Test Conditions, Dates and Approximate Times Set 2

\begin{tabular}{cccccccc}
\hline $\begin{array}{c}\text { Feed } \\
\text { Stoichiometry }\end{array}$ & $\begin{array}{c}\text { Total Solids } \\
\text { Target }\end{array}$ & $\begin{array}{c}\text { Antifoam } \\
\text { Target }\end{array}$ & $\begin{array}{c}\text { Average } \\
\text { Bubbling } \\
\text { Rate }\end{array}$ & $\begin{array}{c}\text { Average Vapor } \\
\text { Space } \\
\text { Tempe rature }\end{array}$ & Condition & Start Date/Time & End Date/Time \\
\hline $100 \%$ & $45 \%$ & nominal & --- & --- & --- & $3 / 8 / 201410: 16$ & $3 / 10 / 201417: 33$ \\
\hline $100 \%$ & $42 \%$ & nominal & $0.5 \mathrm{scfm}$ & $720^{\circ} \mathrm{C}$ & surge & $3 / 10 / 201417: 33$ & $3 / 15 / 20149: 40$ \\
\hline $100 \%$ & $42 \%$ & nominal & $0.003 \mathrm{scfm}$ & $713^{\circ} \mathrm{C}$ & surge & $3 / 15 / 201413: 24$ & $3 / 16 / 201413: 50$ \\
\hline $100 \%$ & $45 \%$ & $\sim 3 \mathrm{X}$ nominal & --- & --- & --- & $3 / 16 / 201416: 48$ & $3 / 17 / 201412: 12$ \\
\hline $100 \%$ & $45 \%$ & $\sim 2 \mathrm{X}$ nominal & $0.003 \mathrm{scfm}$ & $604^{\circ} \mathrm{C}$ & steady state & $3 / 17 / 201418: 12$ & $3 / 17 / 201420: 27$ \\
\hline $100 \%$ & $45 \%$ & $\sim 2 \mathrm{X}$ nominal & $0.003 \mathrm{scfm}$ & $519^{\circ} \mathrm{C}$ & steady state & $3 / 18 / 20146: 40$ & $3 / 18 / 20148: 42$ \\
\hline $100 \%$ & $45 \%$ & $\sim 2 \mathrm{X}$ nominal & $0.003 \mathrm{scfm}$ & $397^{\circ} \mathrm{C}$ & steady state & $3 / 18 / 201413: 08$ & $3 / 18 / 201415: 08$ \\
\hline $100 \%$ & $45 \%$ & $\sim 2 \mathrm{X}$ nominal & $0.003 \mathrm{scfm}$ & $323^{\circ} \mathrm{C}$ & steady state & $3 / 18 / 201419: 32$ & $3 / 18 / 201421: 32$ \\
\hline $100 \%$ & $45 \%$ & $\sim 2 \mathrm{X}$ nominal & $0.003 \mathrm{scfm}$ & $293^{\circ} \mathrm{C}$ & steady state & $3 / 18 / 201422: 38$ & $3 / 18 / 201423: 08$ \\
\hline $125 \%$ & $45 \%$ & nominal & $0.003 \mathrm{scfm}$ & $486^{\circ} \mathrm{C}$ & steady state & $3 / 19 / 201416: 13$ & $3 / 19 / 201418: 13$ \\
\hline $125 \%$ & $45 \%$ & nominal & $0.003 \mathrm{scfm}$ & $604^{\circ} \mathrm{C}$ & steady state & $3 / 20 / 20140: 30$ & $3 / 20 / 20142: 45$ \\
\hline $100 \%$ & $45 \%$ & $\sim 2 \mathrm{X}$ nominal & $0.003 \mathrm{scfm}$ & $722^{\circ} \mathrm{C}$ & steady state & $3 / 20 / 201421: 26$ & $3 / 20 / 201422: 00$ \\
\hline
\end{tabular}

Note that "---“" signifies test conditions during which difficulties were encountered. No data were generated for steady state or surge testing. 


\subsection{Turnover}

The first $125 \%$ stoichiometry feed ${ }^{1}$ addition occurred on February 24, 2014 at approximately 22:55. Approximately 24 hours of feeding with a feed rate in the range of 132-305 g/min under argon bubbling ( 0.002-0.5 scfm per bubbler $\left.{ }^{\mathrm{m}}\right)$ were required to complete one turnover of the melter volume. Approximately $108 \mathrm{~kg}$ of glass were poured from the melter. ${ }^{\mathrm{n}}$ This time was also used to monitor temperature and controller responses throughout the system. The average melt pool temperature during turnover was approximately $1016^{\circ} \mathrm{C}$, while the vapor space was maintained at an average temperature of $732^{\circ} \mathrm{C}$. Melter turnover was completed on February 25, 2014 at approximately 22:38.

\section{$4.3125 \%$ Stoichiometry Melter Feed}

After the melter turnover was completed, several attempts were made to conduct the $700^{\circ} \mathrm{C}$ vapor space steady state testing on February 26 with an argon bubbling rate of $\sim 0.5 \mathrm{scfm}$ per bubbler. Steady state conditions were not achieved with the $\sim 49 \mathrm{wt} \%$ total solids feed and thus the bubbling rate was reduced to $\sim 0.25 \mathrm{scfm}$ per bubbler. After approximately 5 hours the bubbling rate was further reduced to $\sim 0.2 \mathrm{scfm}$ per bubbler and a decision was made by the technical lead to dilute the feed to $45 \mathrm{wt} \%$ total solids. Feeding was initiated with the $45 \mathrm{wt} \%$ total solids feed on February 26 at 16:39. More details of specific tests performed with this melter feed will be provided in the following sections.

\subsubsection{Steady State Vapor Space Testing (Bubbled)}

Steady state testing with the $125 \%$ stoichiometry feed ( $45 \mathrm{wt} \%$ total solids) with an argon bubbling rate of 0.1-0.2 scfm per bubbler began on February 26 at 20:28 and was completed on February 28 at 16:47. A summary of the primary test conditions for each vapor space temperature test are shown in Table 4-5 and Table 4-6. The initial temperature was $\sim 705^{\circ} \mathrm{C}$ and the feed rate, vapor space heater output and air purge were incrementally adjusted to reduce the target vapor space temperature. Additional purge air in the range of $15-51 \mathrm{scfm}$ was required to achieve vapor space temperatures below $\sim 625^{\circ} \mathrm{C}$. Feed rate was reduced somewhat linearly $\left(\mathrm{R}^{2}=0.94\right)$ in the range of $72-215 \mathrm{~g} / \mathrm{min}$ for each vapor space temperature below $700^{\circ} \mathrm{C}$ as shown in Figure 4-1. A comparison of the actual glass production rate and calculated rate is shown in Figure 4-2. The actual glass production rates are comparable; however, there is a larger deviation between the two values at $705^{\circ} \mathrm{C}$. A cause for this difference is unknown. Images of the cold cap throughout steady state testing are shown in Figure 4-3 and Figure 4-4. Generally, it appears that feeding was sufficient at each of the vapor space temperatures to meet the desired cold cap coverage with the presence of some vent holes without overfeeding or underfeeding the melter.

Table 4-5. 125\% Bubbled Steady State Vapor Space Temperature Test Conditions

\begin{tabular}{cccc}
\hline $\begin{array}{c}\text { Ave rage Vapor } \\
\text { Space Tempe rature } \\
\left({ }^{\circ} \mathbf{C}\right)\end{array}$ & $\begin{array}{c}\text { Average Glass } \\
\text { Pool Te mpe rature } \\
\left({ }^{\circ} \mathbf{C}\right)\end{array}$ & $\begin{array}{c}\text { Average Film } \\
\text { Cooler Flow } \\
(\mathbf{s c f m})\end{array}$ & $\begin{array}{c}\text { Average Melter } \\
\text { Air Purge } \\
(\mathbf{s c f m})\end{array}$ \\
\hline 705 & 1033 & 16 & 1 \\
\hline 625 & 1032 & 16 & 1 \\
\hline 481 & 1025 & 16 & 15 \\
\hline 405 & 1026 & 16 & 22 \\
\hline 358 & 1017 & 9 & 40 \\
\hline 271 & 1035 & 6 & 51 \\
\hline
\end{tabular}

\footnotetext{
${ }^{1} 49 \mathrm{wt} \%$ total solids

${ }^{\mathrm{m}}$ There are two bubblers in the CEF melt pool.

${ }^{\mathrm{n}}$ Prior to testing the melter was filled with approximately $105 \mathrm{~kg}$ of glass that was fabricated during Phase I testing (SB6-Frit 418).
} 
Table 4-6. $125 \%$ Bubbled Steady State Vapor Space Temperature Test Conditions

\begin{tabular}{cccc}
\hline $\begin{array}{c}\text { Average Vapor } \\
\text { Space Temperature } \\
\left({ }^{\circ} \mathbf{C}\right)\end{array}$ & $\begin{array}{c}\text { Average Feed } \\
\text { Rate } \\
(\mathbf{g} / \mathbf{m i n})\end{array}$ & $\begin{array}{c}\text { Average Melter } \\
\text { Press ure (inwc) }\end{array}$ & $\begin{array}{c}\text { Average Vapor } \\
\text { Space Output } \\
\text { (volts) }\end{array}$ \\
\hline 705 & 215 & -5 & 123 \\
\hline 625 & 161 & -5 & 67 \\
\hline 481 & 108 & -5 & 19 \\
\hline 405 & 99 & -5 & 8 \\
\hline 358 & 79 & -4 & 8 \\
\hline 271 & 72 & -1 & \\
\hline
\end{tabular}

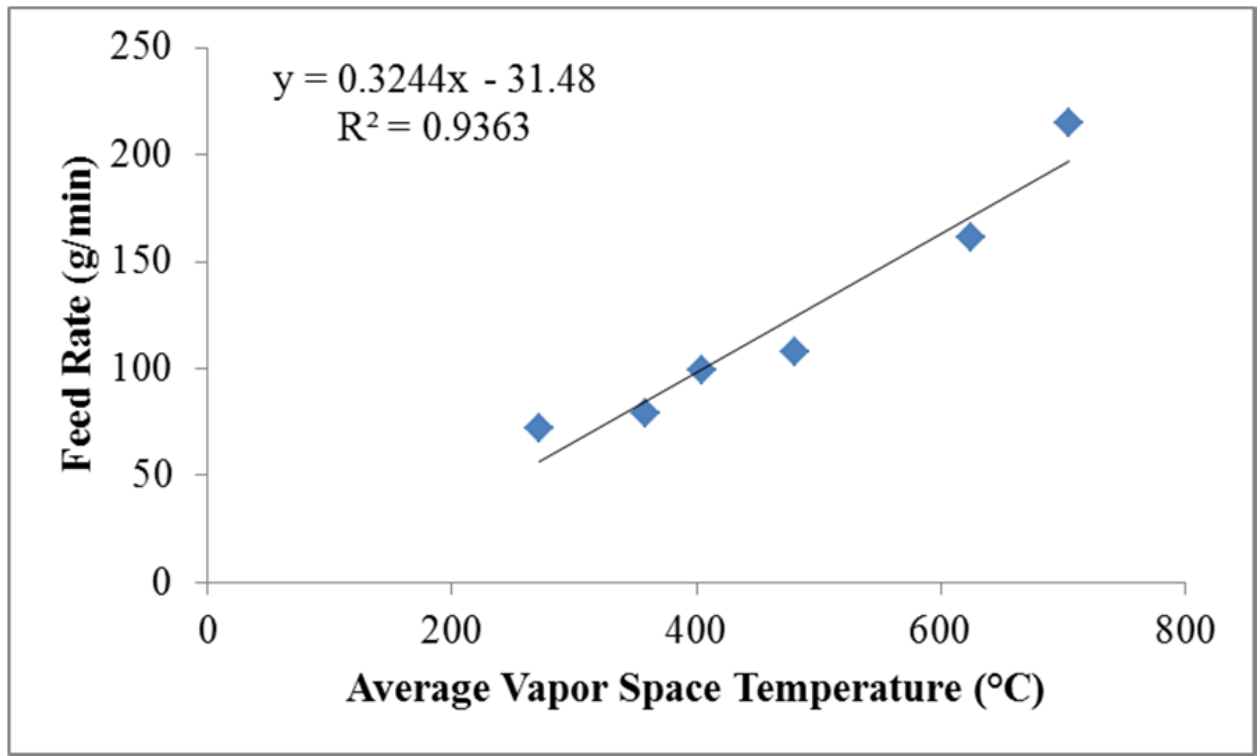

Figure 4-1. 125\% stoichiometry bubbled feed rate as a function of vapor space temperature.

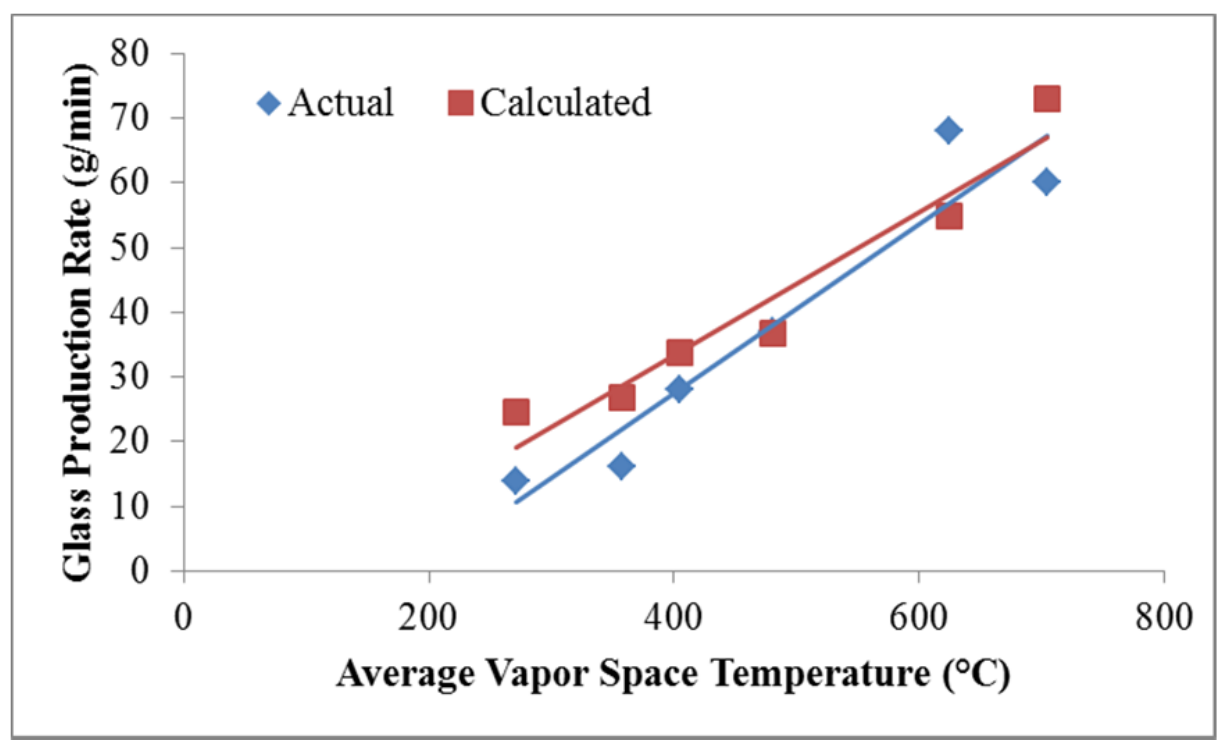

Figure 4-2. $125 \%$ stoichiometry bubbled condition glass production rates. 


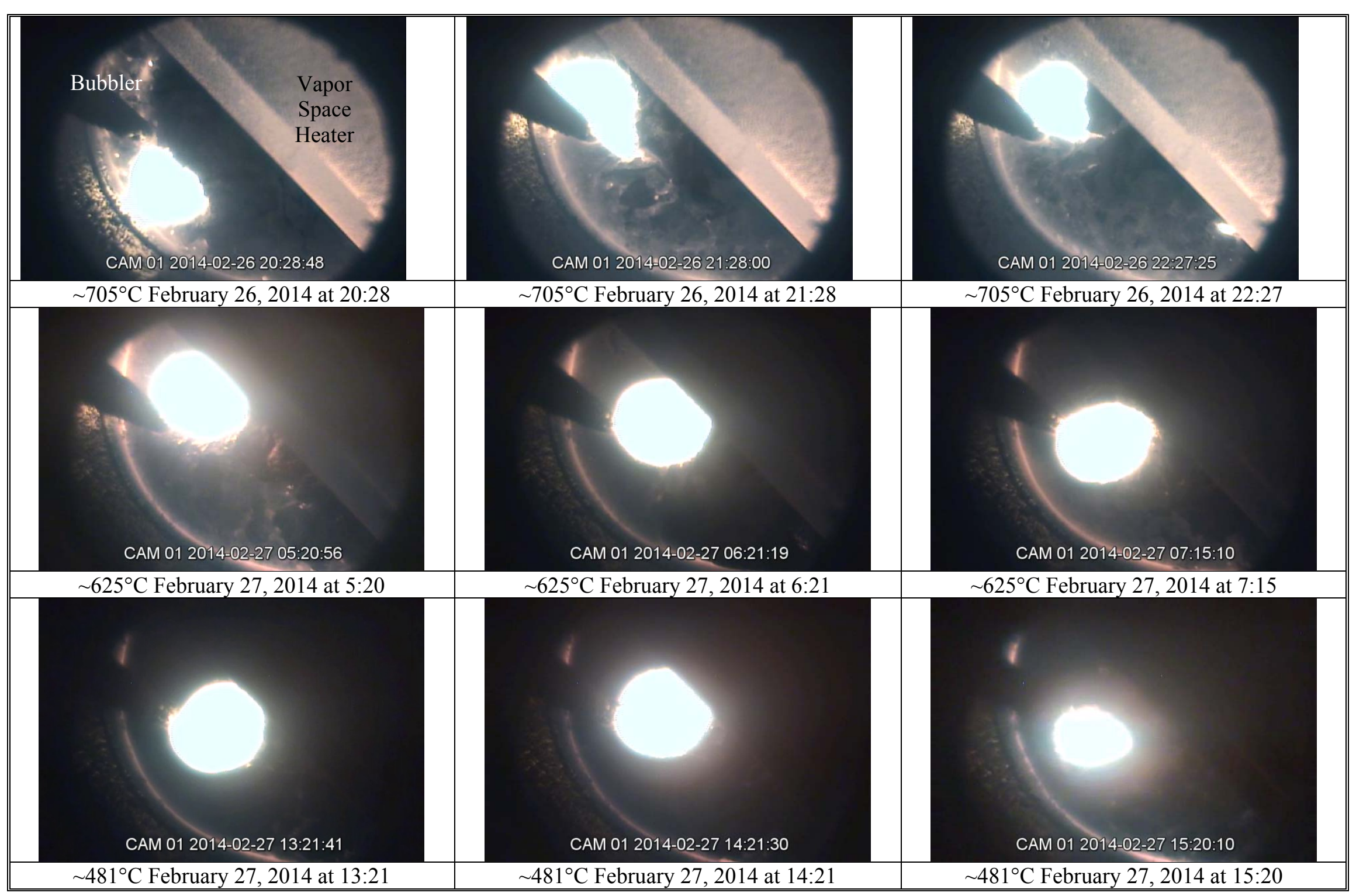

Figure 4-3. Cold cap images during the $125 \%$ stoichiometry bubbled testing. 


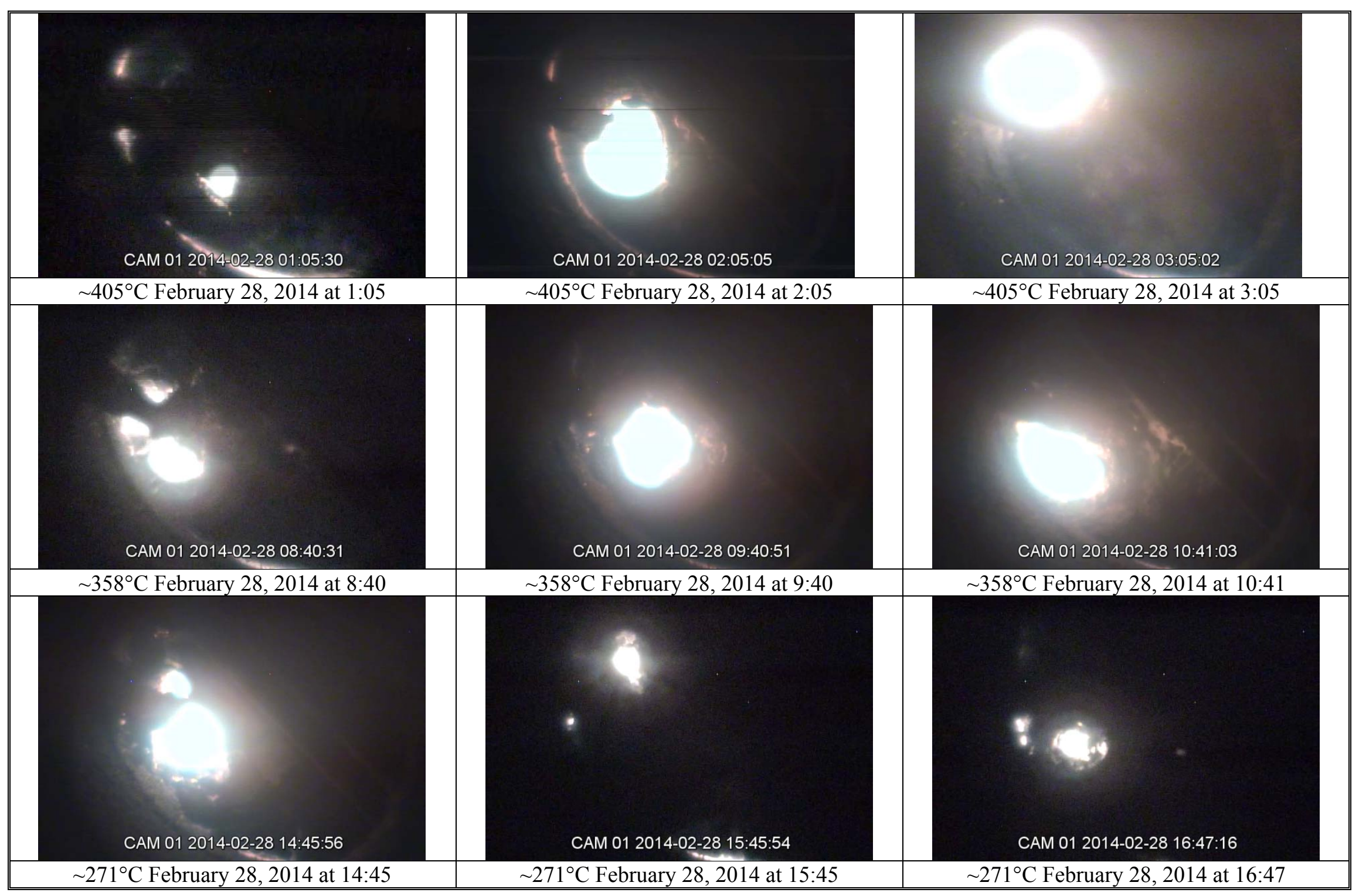

Figure 4-4. Cold cap images during the $125 \%$ stoichiometry bubbled testing. 


\subsubsection{Steady State Vapor Space Conditions (Non-Bubbled)}

Steady state testing with the $125 \%$ stoichiometry feed (45 $\mathrm{wt} \%$ total solids) with an argon bubbling rate of $\sim 0.002 \mathrm{scfm}$ per bubbler began on February 28 at 21:54 and was completed on March 2 at $6: 40 .^{\circ}$ It should be noted that the $500^{\circ} \mathrm{C}$ and $600^{\circ} \mathrm{C}$ vapor space temperature tests were repeated on March $19-20$ due to insufficient feed rates during the first attempts for these tests. A summary of the primary test conditions for each vapor space temperature test are shown in Table 4-7. ${ }^{\mathrm{A}}$

Table 4-7. 125\% Non-Bubbled Steady State Vapor Space Temperature Test Conditions

\begin{tabular}{|c|c|c|c|}
\hline $\begin{array}{c}\text { Average Vapor } \\
\text { Space Tempe rature } \\
\left({ }^{\circ} \mathrm{C}\right)\end{array}$ & $\begin{array}{c}\text { Average Glass } \\
\text { Pool Te mpe rature } \\
\left({ }^{\circ} \mathrm{C}\right) \\
\end{array}$ & $\begin{array}{c}\text { Average Film } \\
\text { Cooler Flow } \\
\text { (scfm) } \\
\end{array}$ & $\begin{array}{c}\text { Average Melter } \\
\text { Air Purge } \\
\text { (s cfim) }\end{array}$ \\
\hline 709 & 1083 & 16 & 1 \\
\hline 604 & 1060 & 16 & 0 \\
\hline 486 & 1059 & 16 & 0 \\
\hline 393 & 1085 & 16 & 15 \\
\hline 351 & 1083 & 16 & 21 \\
\hline 309 & 1080 & 16 & 30 \\
\hline $\begin{array}{c}\text { Average Vapor } \\
\text { Space Tempe rature } \\
\left({ }^{\circ} \mathrm{C}\right) \\
\end{array}$ & $\begin{array}{c}\text { Average Feed } \\
\text { Rate } \\
(\mathrm{g} / \mathrm{min}) \\
\end{array}$ & $\begin{array}{l}\text { Average Melter } \\
\text { Pressure (inwe) }\end{array}$ & $\begin{array}{c}\text { Average Vapor } \\
\text { Space Output } \\
\text { (volts) }\end{array}$ \\
\hline 709 & 99 & -6 & 106 \\
\hline 604 & 100 & -5 & 83 \\
\hline 486 & 86 & -6 & 16 \\
\hline 393 & 54 & -6 & 8 \\
\hline 351 & 44 & -5 & 10 \\
\hline 309 & 35 & -5 & 8 \\
\hline
\end{tabular}

The initial temperature was $\sim 309^{\circ} \mathrm{C}$ and the feed rate, vapor space heater output and air purge were incrementally adjusted to increase the target vapor space temperature. Additional purge air in the range of $15-30 \mathrm{scfm}$ was required to achieve vapor space temperatures below $\sim 486^{\circ} \mathrm{C}$. Feed rates in the range of 35-100 g/min were used for this test as compared to feed rates of $72-215 \mathrm{~g} / \mathrm{min}$ that were used for the bubbled testing. This offset is to be expected since convection in the glass pool facilitates melting of the cold cap. As mentioned previously, the $500^{\circ} \mathrm{C}$ and $600^{\circ} \mathrm{C}$ tests were repeated at a later date, which could account for the lower $\mathrm{R}^{2}$ value shown in Figure 4-5. It is possible that a slightly higher feed rate for the $\sim 709^{\circ} \mathrm{C}$ test could have been used based on the linear fit of the data. A comparison of the actual and calculated glass production rates is shown in Figure 4-6. The $486^{\circ} \mathrm{C}$ test was repeated at a later date, which could be the cause of the deviation between the two rates. Images of the cold cap throughout steady state testing are shown in Figure 4-7 and Figure 4-8. The light color of the cold cap for the $709^{\circ} \mathrm{C}$ test indicates that a higher feed rate could have been used, which is consistent with Figure 4-5. Cracks in the cold cap of the $\sim 393^{\circ} \mathrm{C}$ and $\sim 604^{\circ} \mathrm{C}$ also suggest that a slightly higher feed rate may have been necessary to obtain more consistent coverage. Visually, the characteristics of the cold cap from this

\footnotetext{
${ }^{\circ}$ During non-bubbled conditions, a minimal bubbling rate was maintained in order to reduce the risk of plugging the bubbler ports.

${ }^{\mathrm{p}}$ The melter conditions for the repeated $500^{\circ} \mathrm{C}$ and $600^{\circ} \mathrm{C}$ steady state tests are presented.
} 
nitric-glycolic feed are no different than those observed during the nitric-formic non-bubbled steady state testing conducted for Phase I. ${ }^{\mathrm{q}, 52}$

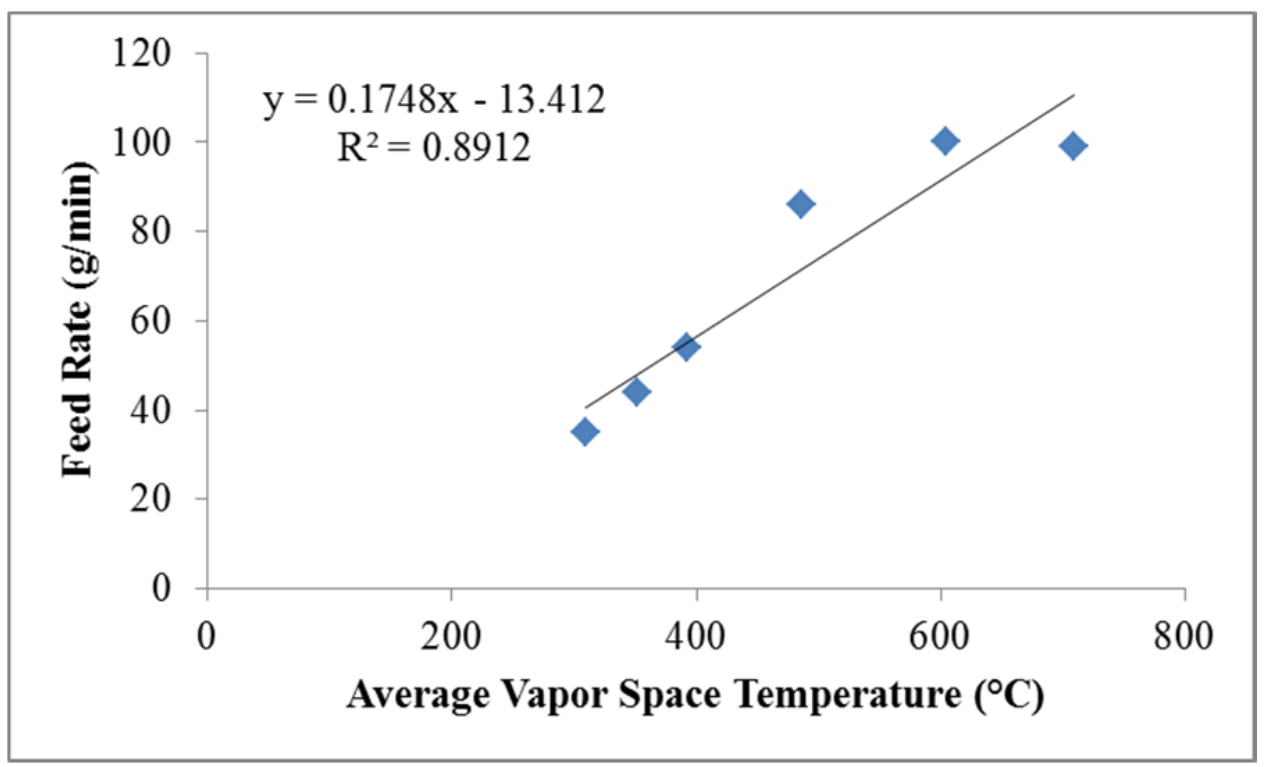

Figure 4-5. $125 \%$ stoichiometry non-bubbled feed rate as a function of vapor space temperature.

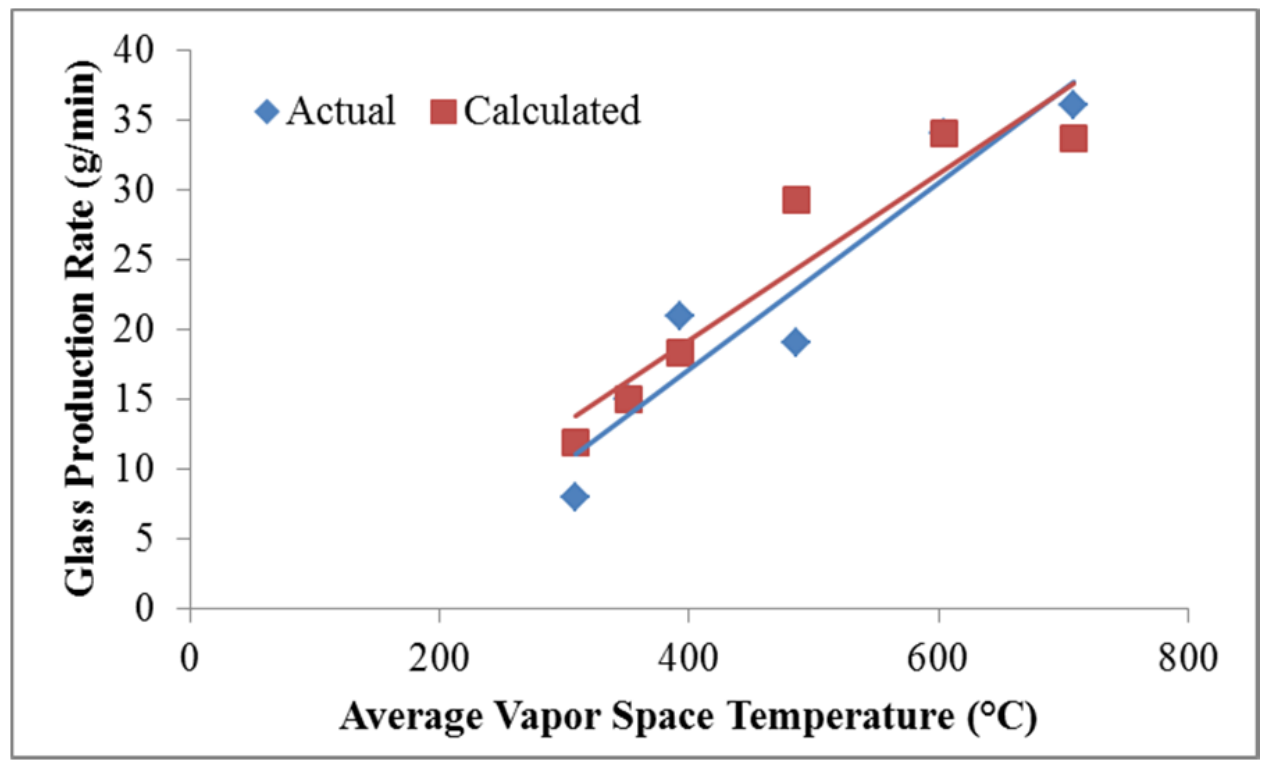

Figure 4-6. $125 \%$ stoichiometry non-bubbled condition glass production rates.

\footnotetext{
${ }^{\mathrm{q}}$ Images of the cold cap during non-bubbled steady state testing were compared between the nitric-glycolic and nitric-formic flowsheets. Images of the nitric-formic flowsheet are shown in the Phase I testing report (SRNL-STI-2014-00005).
} 


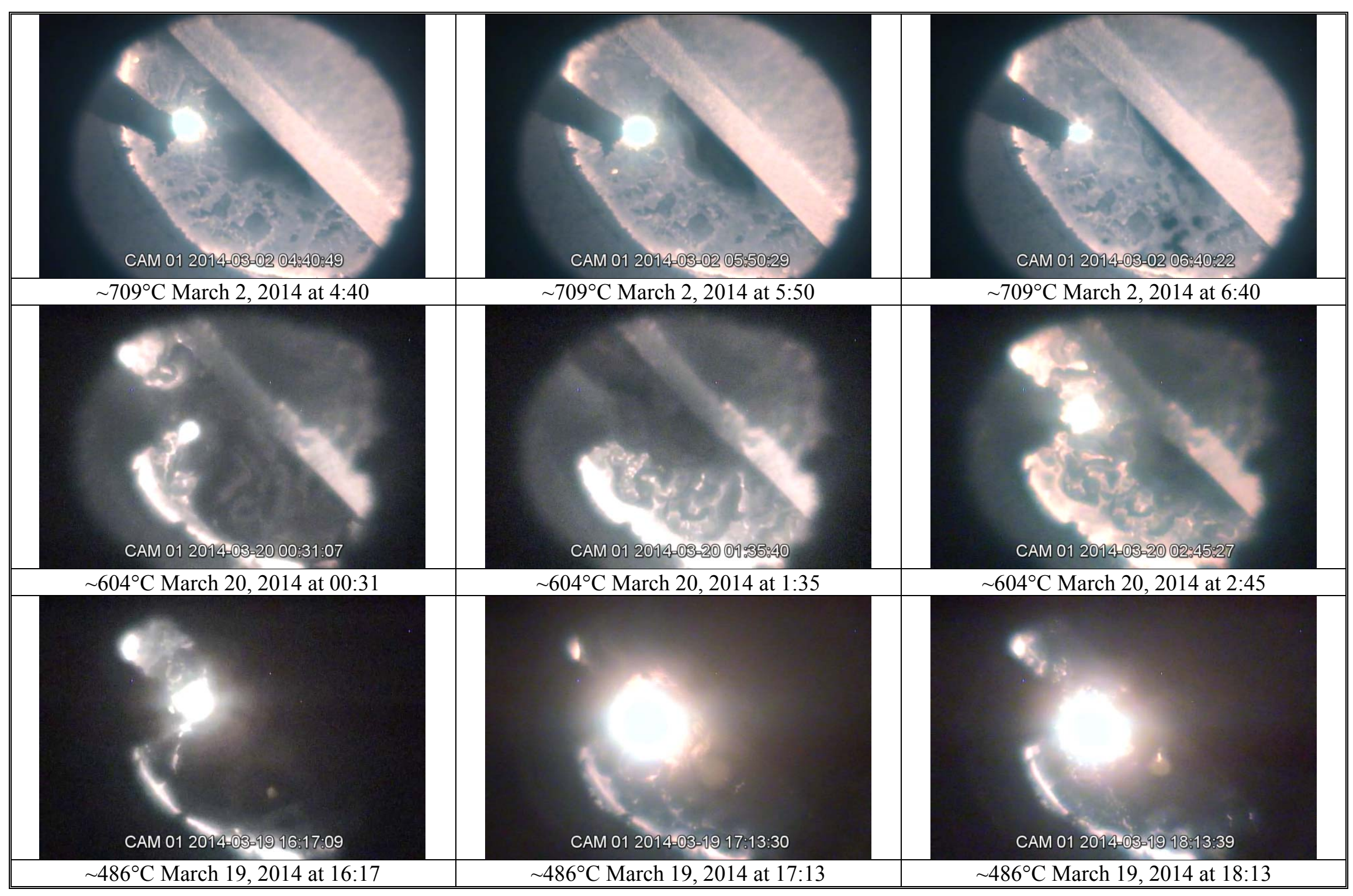

Figure 4-7. Cold cap images during the $125 \%$ stoichiometry non-bubbled testing. 


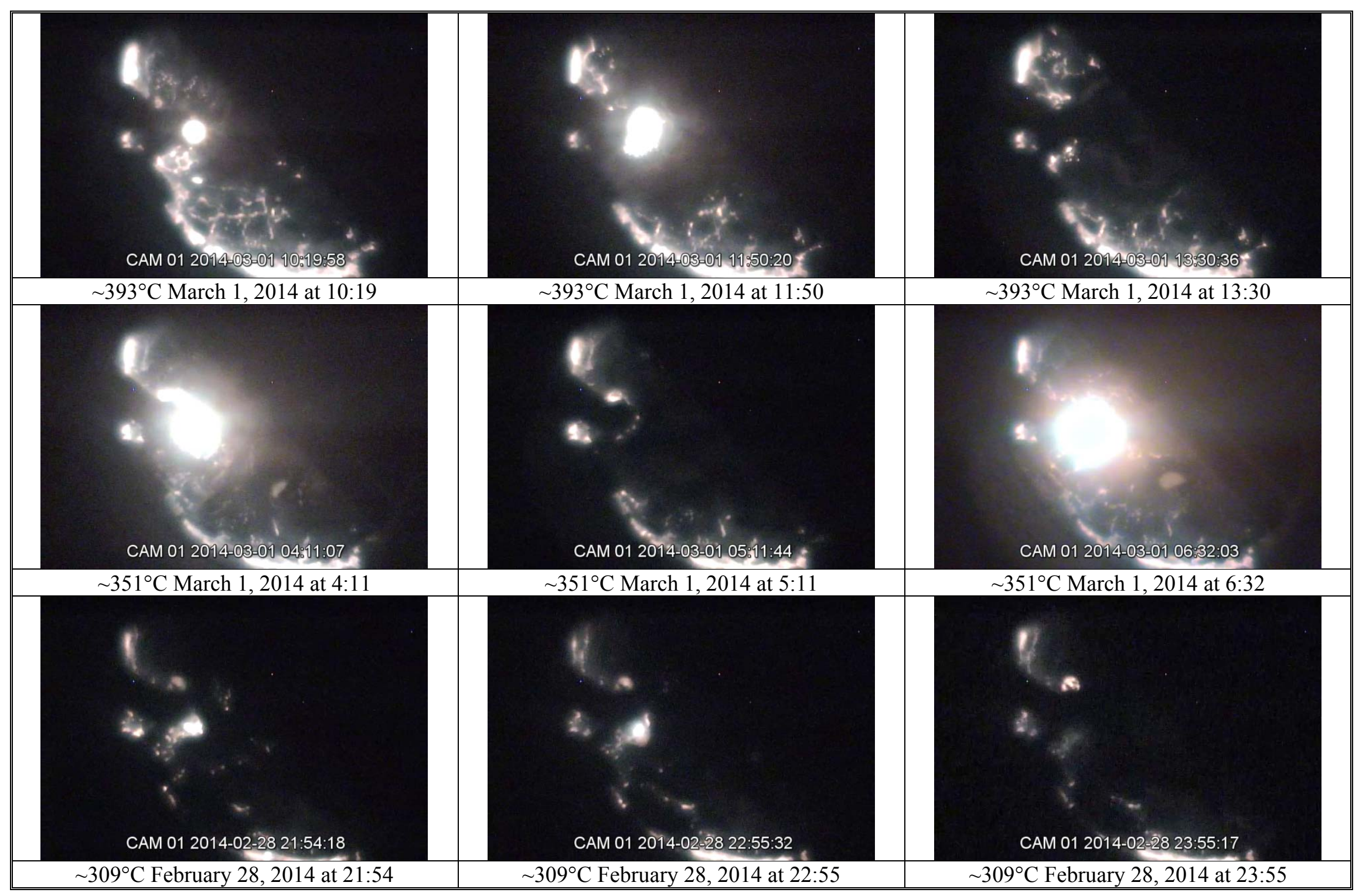

Figure 4-8. Cold cap images during the $125 \%$ stoichiometry non-bubbled testing. 


\subsection{0\% Stoichiometry Melter Feed}

Feeding was initiated on March 2, 2014 at approximately 8:38 and ended on March 16 at approximately 13:50. More details of specific tests performed with this melter feed will be provided in the following sections.

\subsubsection{Steady State Vapor Space Testing (Non-Bubbled)}

Steady state testing with the $100 \%$ stoichiometry feed $\left(45 \mathrm{wt} \%\right.$ total solids ${ }^{\mathrm{r}}$ ) with an argon bubbling rate of $\sim 0.001-0.003 \mathrm{scfm}$ per bubbler began on March 2 at 8:38 and was completed on March 4 at 6:05. ${ }^{\mathrm{s}} \mathrm{A}$ summary of the primary test conditions for each vapor space temperature test are shown in Table 4-8. The initial temperature was $\sim 697^{\circ} \mathrm{C}$ and the feed rate, vapor space heater output and air purge were incrementally adjusted to reduce the vapor space temperature to $\sim 326^{\circ} \mathrm{C}$. Additional purge air in the range of 13-35 scfm was required to achieve vapor space temperatures below $\sim 496^{\circ} \mathrm{C}$, which is comparable to the range of $15-30 \mathrm{scfm}$ that was used for the $125 \%$ stoichiometry non-bubbled testing. Feed rate was decreased linearly $\left(\mathrm{R}^{2}=0.97\right)$ in the range of $43-118 \mathrm{~g} / \mathrm{min}$ for each vapor space temperature below $\sim 697^{\circ} \mathrm{C}$ as shown in Figure 4-9. A comparison of the actual and calculated glass production rates are shown in Figure 4-10. Images of the cold cap throughout steady state testing are shown in Figure 4-11 and Figure 4-12. The light color (orange glow) of the cold cap for the $\sim 697^{\circ} \mathrm{C}$ and $\sim 600^{\circ} \mathrm{C}$ test is an indication of underfeeding, as well as the cracks in the cold cap that were present for the $\sim 496^{\circ} \mathrm{C}$ test.

Table 4-8. $100 \%$ Non-Bubbled Steady State Vapor Space Temperature Test Conditions

\begin{tabular}{|c|c|c|c|}
\hline $\begin{array}{c}\text { Average Vapor } \\
\text { Space Tempe rature } \\
\left({ }^{\circ} \mathrm{C}\right)\end{array}$ & $\begin{array}{c}\text { Average Glass } \\
\text { Pool Tempe rature } \\
\left({ }^{\circ} \mathrm{C}\right)\end{array}$ & $\begin{array}{c}\text { Average Film } \\
\text { Cooler Flow } \\
\text { (scfm) }\end{array}$ & $\begin{array}{c}\text { Average Melter } \\
\text { Air Purge } \\
\text { (scfim) }\end{array}$ \\
\hline 697 & 1086 & 16 & 0 \\
\hline 600 & 1085 & 17 & 0 \\
\hline 496 & 1068 & 17 & 0 \\
\hline 410 & 1074 & 17 & 13 \\
\hline 344 & 1078 & 16 & 28 \\
\hline 326 & 1079 & 10 & 35 \\
\hline $\begin{array}{c}\text { Average Vapor } \\
\text { Space Tempe rature } \\
\left({ }^{\circ} \mathrm{C}\right)\end{array}$ & $\begin{array}{c}\text { Average Feed } \\
\text { Rate } \\
(\mathrm{g} / \mathrm{min}) \\
\end{array}$ & $\begin{array}{l}\text { Average Melter } \\
\text { Pressure (inwc) }\end{array}$ & $\begin{array}{c}\text { Average Vapor } \\
\text { Space Output } \\
\text { (volts) }\end{array}$ \\
\hline 697 & 118 & -5 & 114 \\
\hline 600 & 92 & -6 & 80 \\
\hline 496 & 85 & -6 & 20 \\
\hline 410 & 55 & -6 & 8 \\
\hline 344 & 47 & -5 & 8 \\
\hline 326 & 43 & -4 & 8 \\
\hline
\end{tabular}

\footnotetext{
${ }^{\mathrm{r}}$ Since the $125 \%$ stoichiometry feed was diluted to $45 \mathrm{wt} \%$ total solids, the $100 \%$ stoichiometry feed was also diluted to $45 \mathrm{wt} \%$ total solids so that direct comparisons could be made for the flammability model development.

${ }^{\mathrm{s}}$ During non-bubbled conditions, a minimal bubbling rate was maintained in order to reduce the risk of plugging the bubbler ports.
} 


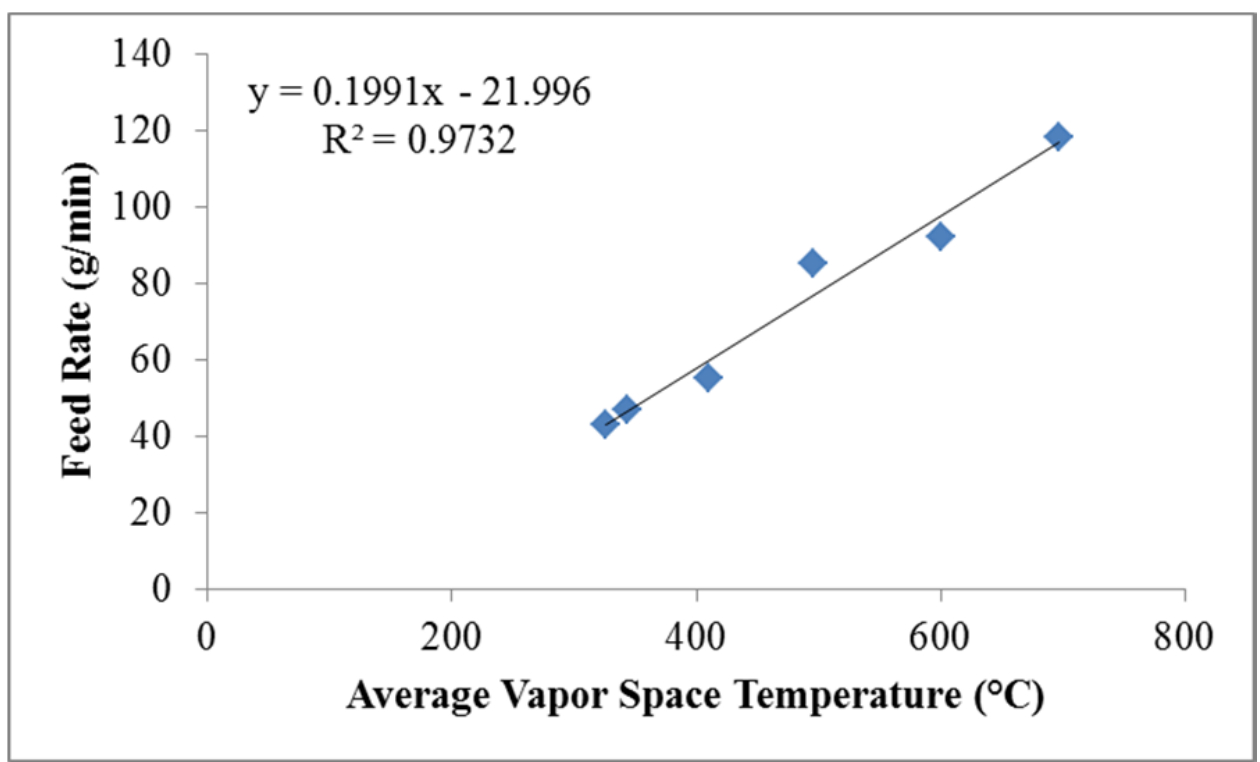

Figure 4-9. $100 \%$ stoichiometry non-bubbled feed rate as a function of vapor space temperature.

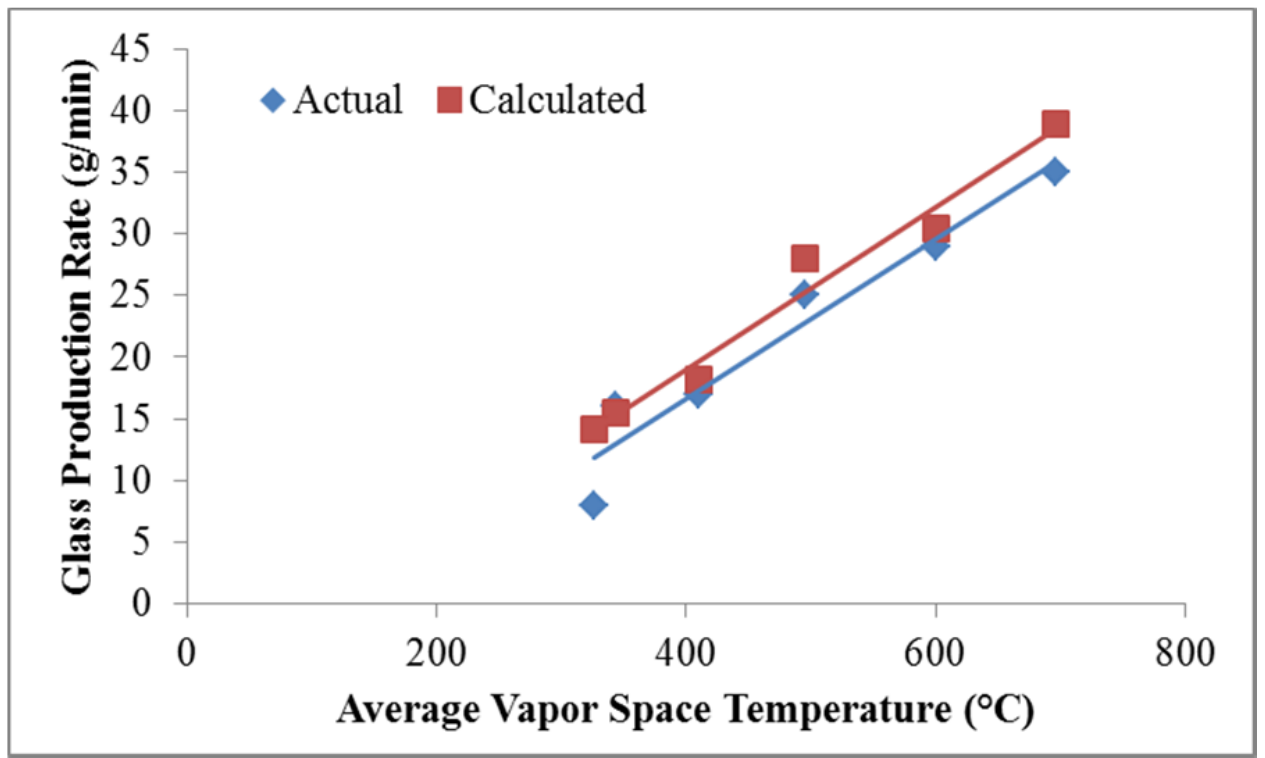

Figure 4-10. $100 \%$ stoichiometry non-bubbled condition glass production rates. 


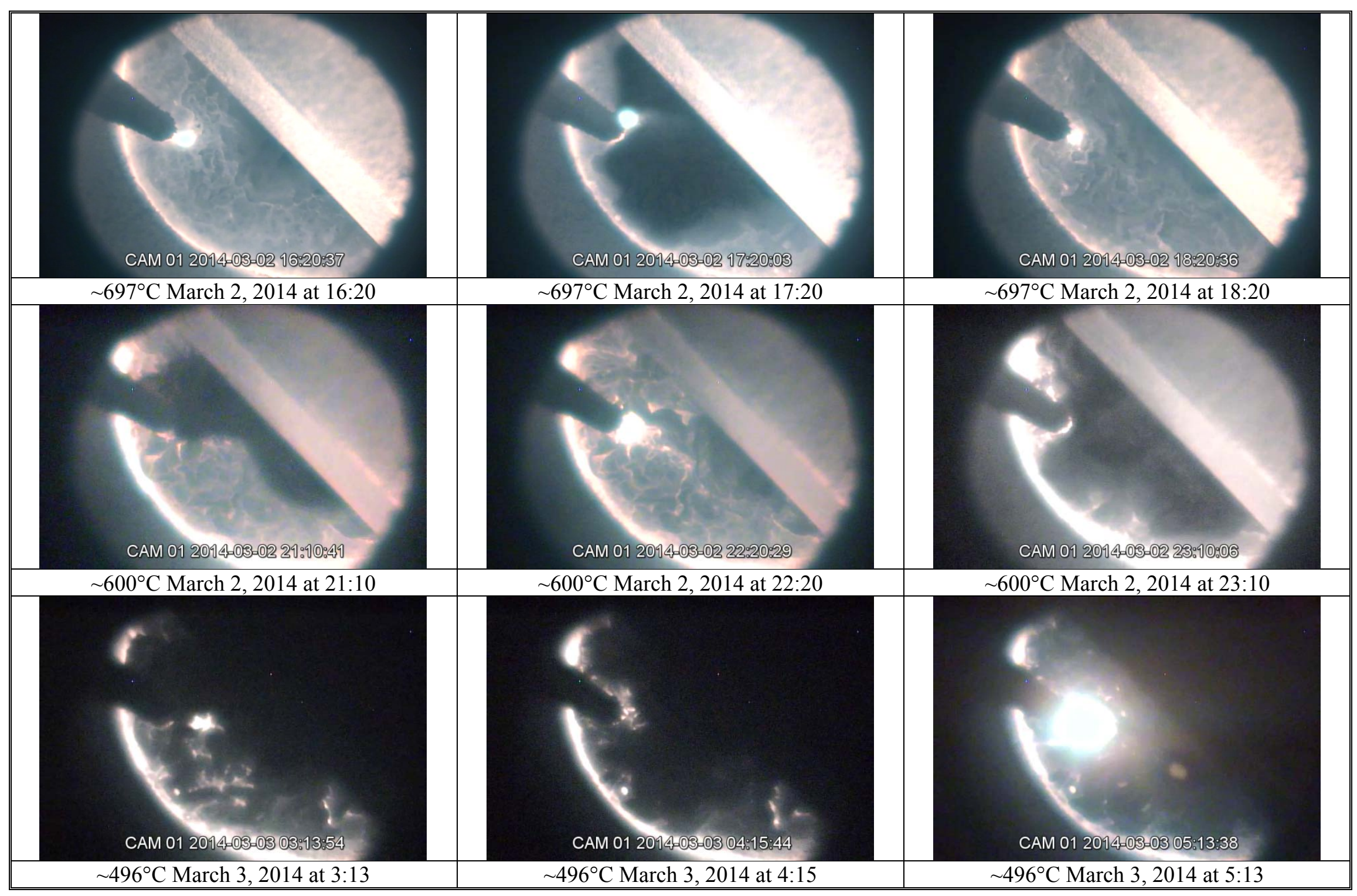

Figure 4-11. Cold cap images during the $100 \%$ stoichiometry non-bubbled testing. 


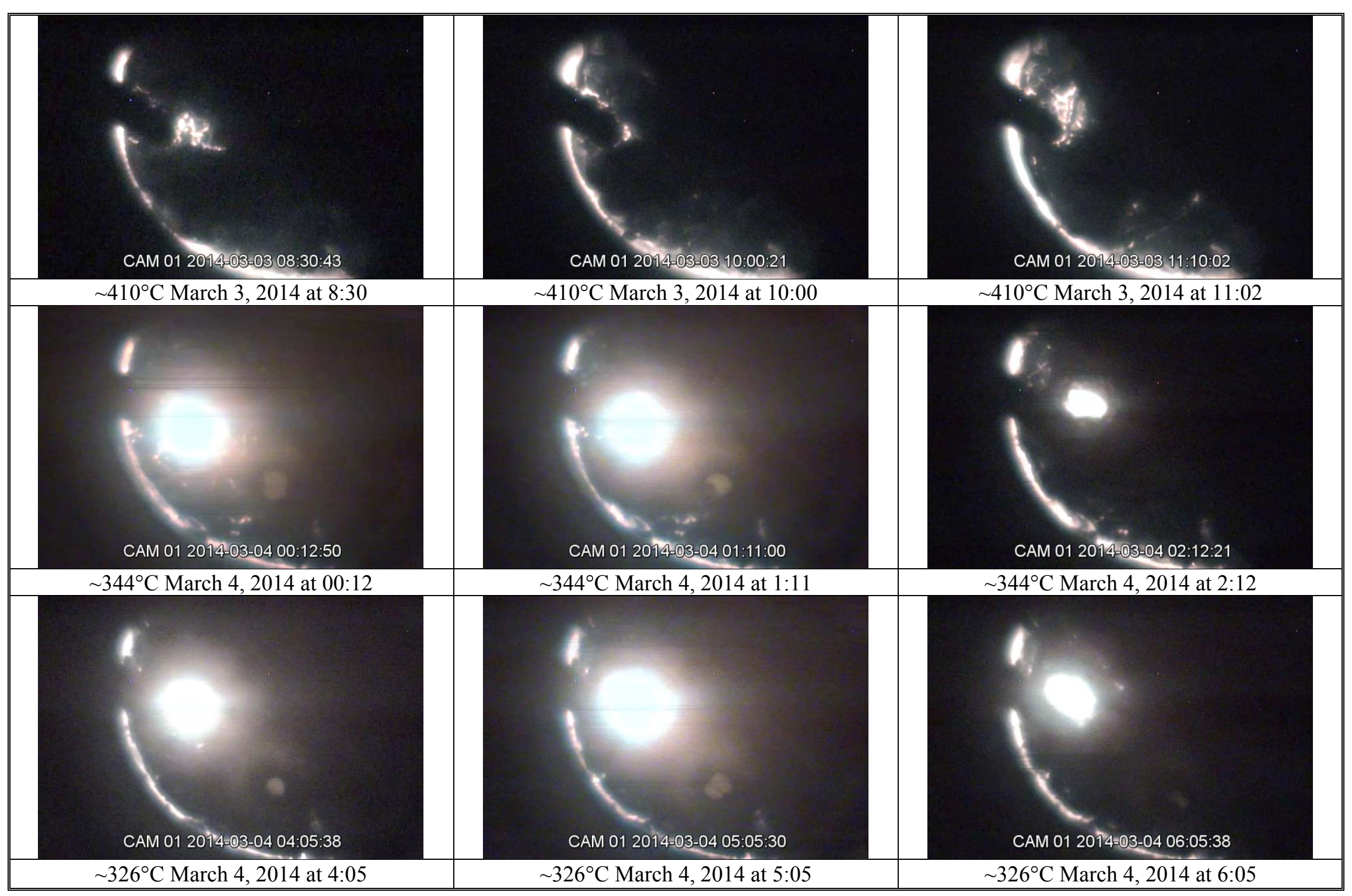

Figure 4-12. Cold cap images during the $100 \%$ stoichiometry non-bubbled testing. 


\subsubsection{Steady State Vapor Space Testing (Bubbled)}

Steady state testing with the $100 \%$ stoichiometry feed (45 $\mathrm{wt} \%$ total solids) with an argon bubbling rate of $\sim 0.2 \mathrm{scfm}$ per bubbler began on March 4 at 20:24 and was completed on March 8 at 8:30. A summary of the primary test conditions for each vapor space temperature test are shown in Table 4-9. The initial temperature was $\sim 323^{\circ} \mathrm{C}$ and the feed rate, vapor space heater output and air purge were incrementally adjusted to increase the vapor space temperature to $\sim 750^{\circ} \mathrm{C}$. Additional purge air in the range of 6-46 scfm was required to achieve vapor space temperatures below $\sim 521^{\circ} \mathrm{C}$, which is comparable to the range used for the $125 \%$ stoichiometry bubbled testing. Feed rate was increased linearly $\left(\mathrm{R}^{2}=0.97\right)$ in the range of $88-179 \mathrm{~g} / \mathrm{min}$ for each vapor space temperature above $\sim 323^{\circ} \mathrm{C}$ as shown in Figure $4-13$. As expected, these feed rates during bubbled testing were higher than those during non-bubbled testing due to the convection in the melt pool. A comparison of the actual and calculated glass production rates are shown in Figure 4-14. Images of the cold cap throughout steady state testing are shown in Figure 4-15 through Figure 4-17. In general, there do not appear to be any signs of underfeeding or overfeeding.

Table 4-9. 100\% Bubbled Steady State Vapor Space Temperature Test Conditions

\begin{tabular}{|c|c|c|c|}
\hline $\begin{array}{c}\text { Average Vapor } \\
\text { Space Te mpe rature } \\
\left({ }^{\circ} \mathrm{C}\right)\end{array}$ & $\begin{array}{c}\text { Average Glass } \\
\text { Pool Tempe rature } \\
\left({ }^{\circ} \mathrm{C}\right) \\
\end{array}$ & $\begin{array}{c}\text { Average Film } \\
\text { Cooler Flow } \\
\text { (scfm) } \\
\end{array}$ & $\begin{array}{c}\text { Average Melter } \\
\text { Air Purge } \\
\text { (scfim) }\end{array}$ \\
\hline 750 & 1054 & 15 & 1 \\
\hline 705 & 1050 & 15 & 1 \\
\hline 607 & 1053 & 15 & 0 \\
\hline 521 & 1035 & 15 & 1 \\
\hline 471 & 1041 & 15 & 6 \\
\hline 373 & 1025 & 16 & 26 \\
\hline 323 & 1031 & 6 & 46 \\
\hline $\begin{array}{c}\text { Average Vapor } \\
\text { Space Tempe rature } \\
\left({ }^{\circ} \mathrm{C}\right)\end{array}$ & $\begin{array}{c}\text { Average Feed } \\
\text { Rate } \\
(\mathrm{g} / \mathrm{min}) \\
\end{array}$ & $\begin{array}{l}\text { Average Melter } \\
\text { Pressure (inwc) }\end{array}$ & $\begin{array}{c}\text { Average Vapor } \\
\text { Space Output } \\
\text { (volts) }\end{array}$ \\
\hline 750 & 179 & -5 & 136 \\
\hline 705 & 171 & -5 & 136 \\
\hline 607 & 156 & -5 & 95 \\
\hline 521 & 118 & -5 & 8 \\
\hline 471 & 112 & -4 & 8 \\
\hline 373 & 101 & -5 & 8 \\
\hline 323 & 88 & -1 & 8 \\
\hline
\end{tabular}




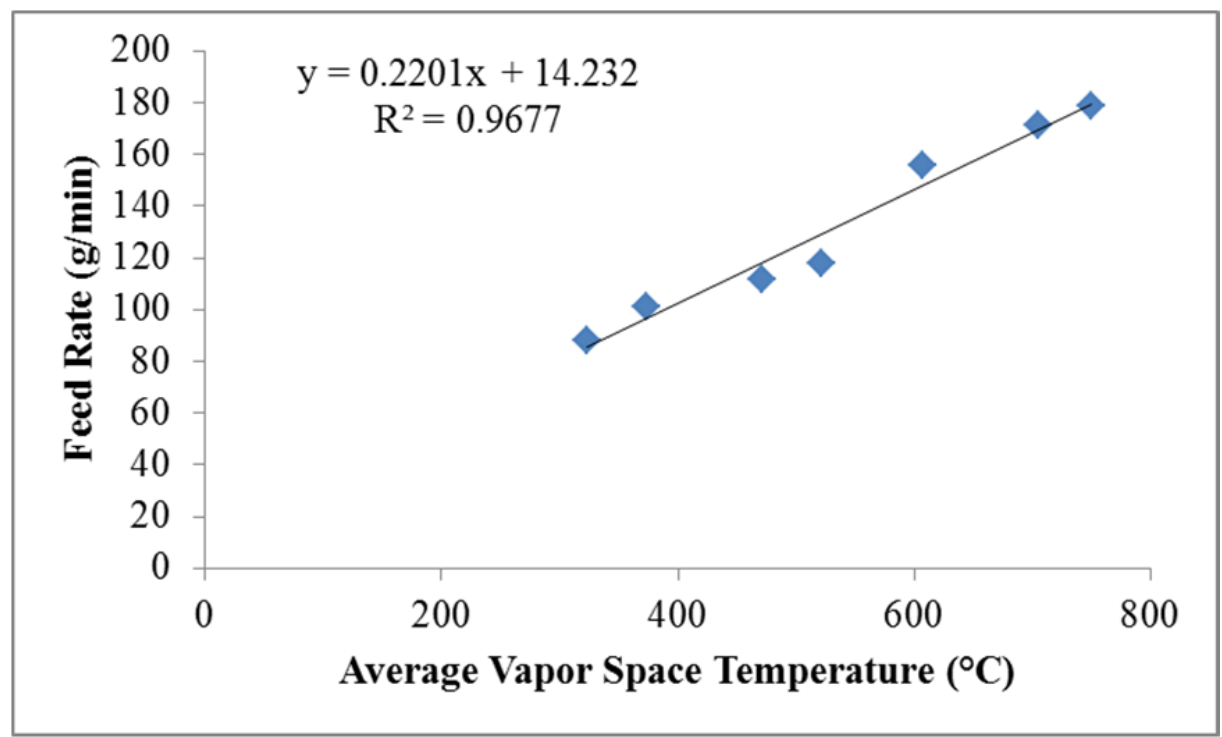

Figure 4-13. $100 \%$ stoichiometry bubbled feed rate as a function of vapor space temperature.

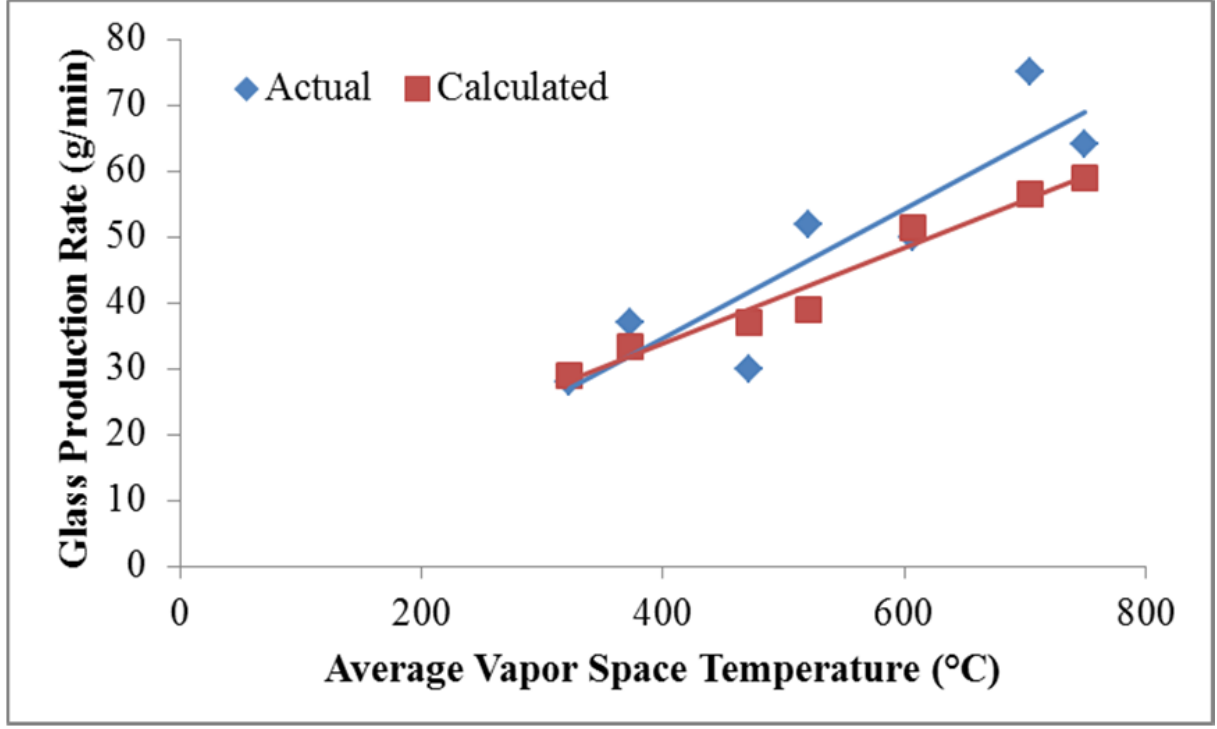

Figure 4-14. $100 \%$ stoichiometry bubbled condition glass production rates.

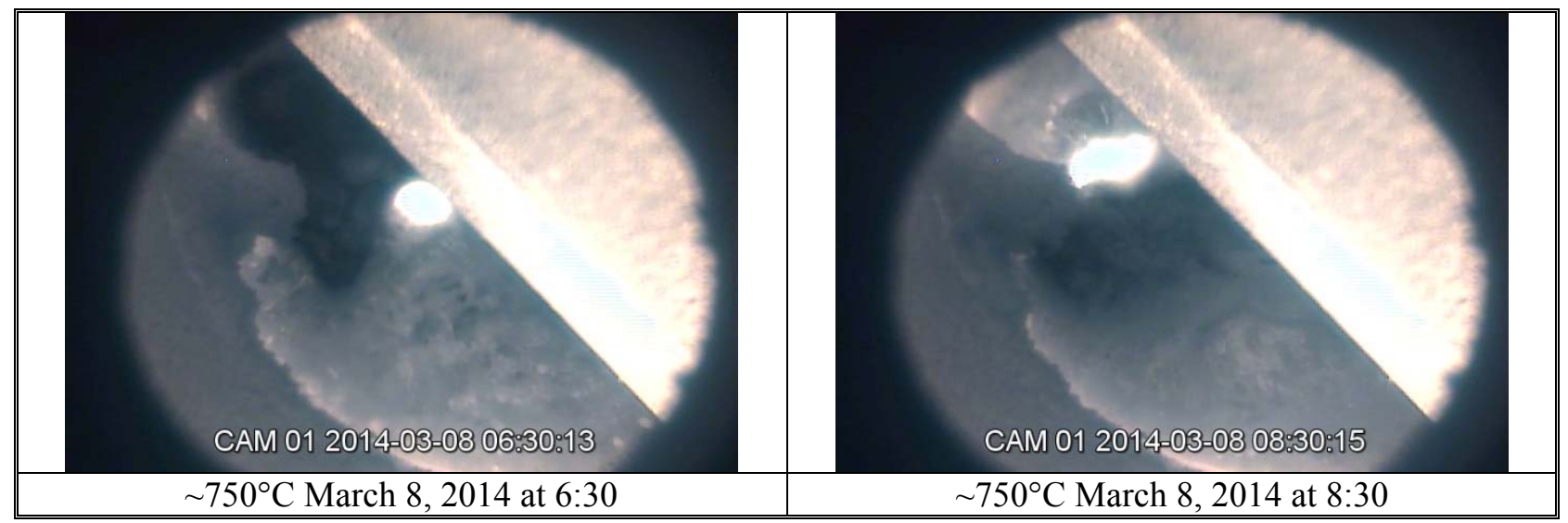

Figure 4-15. Cold cap images during the $100 \%$ stoichiometry bubbled testing. 


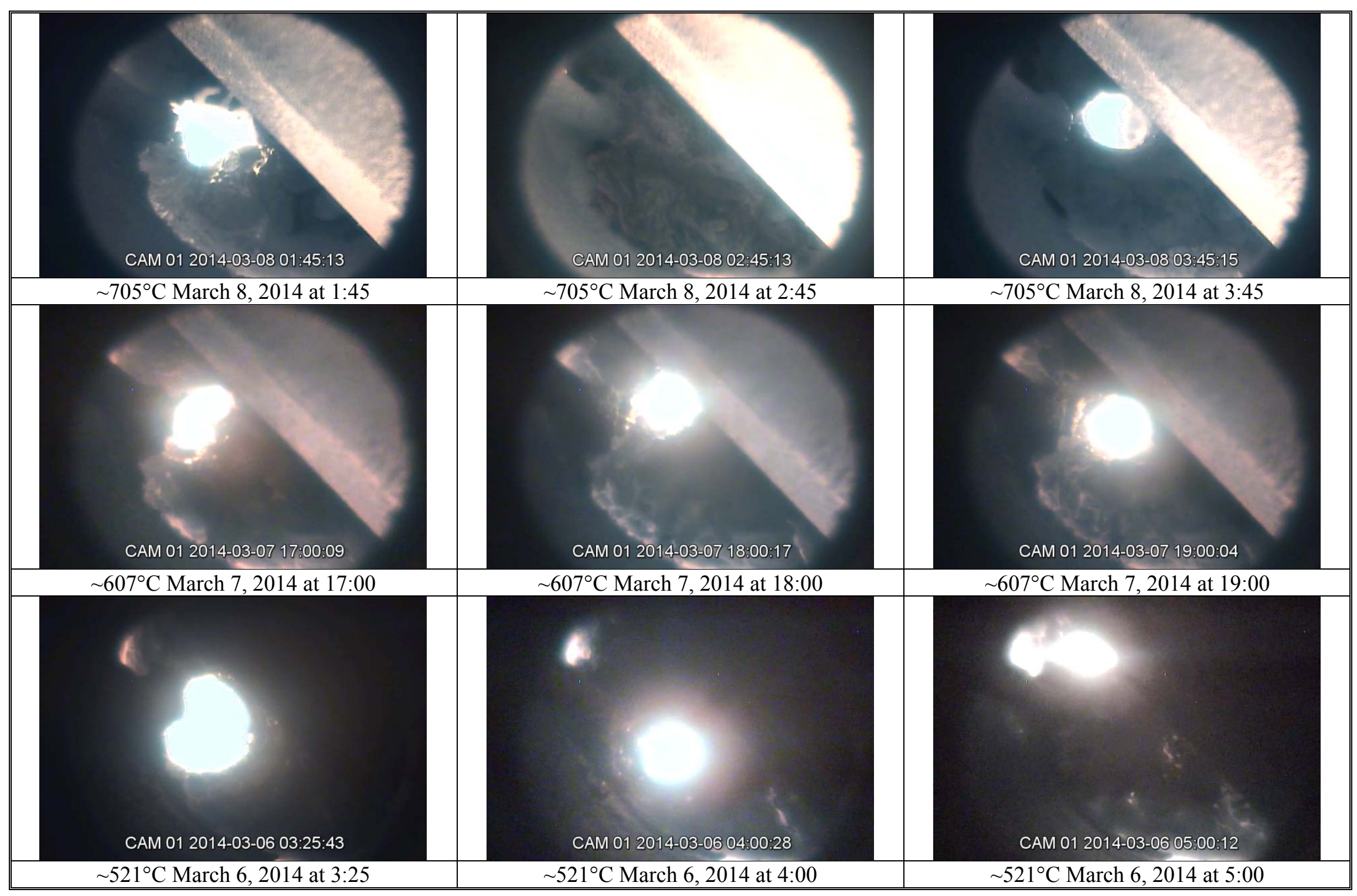

Figure 4-16. Cold cap images during the $100 \%$ stoichiometry bubbled testing. 


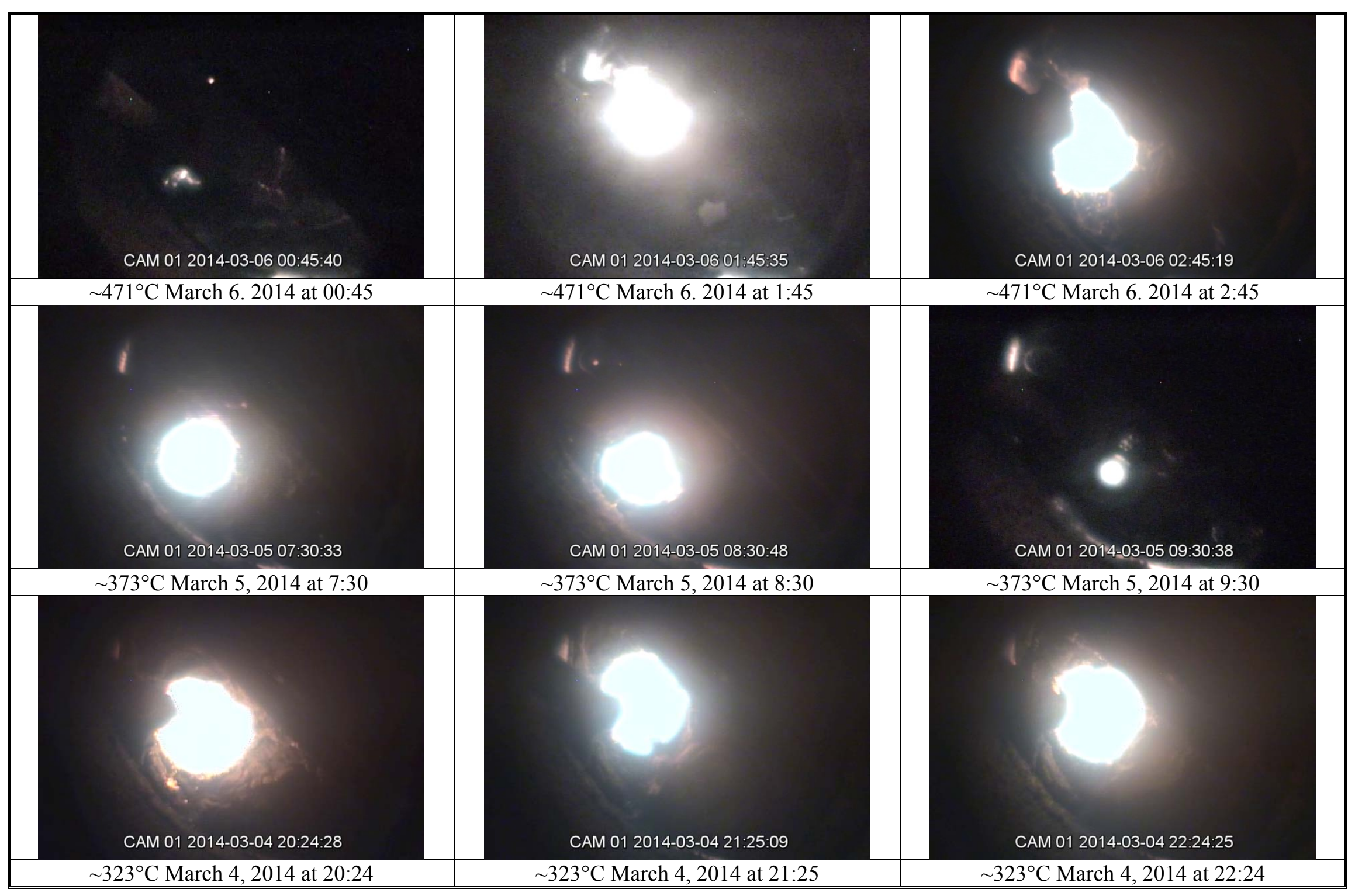

Figure 4-17. Cold cap images during the $100 \%$ stoichiometry bubbled testing. 


\subsubsection{Surge Testing (Bubbled at $45 w t \%$ total solids)}

Bubbled surge testing was initiated with the $100 \%$ stoichiometry feed at a $45 \mathrm{wt} \%$ total solids target on March 8, 2014 at approximately 10:15 with an argon rate of $\sim 0.5$ per bubbler ( $\sim 1 \mathrm{scfm}$ total). The first pressure spike above 0 inwc occurred on March 9, 2014 at approximately 3:30, which was followed by several positive pressure spikes starting at approximately 8:05 (elapsed time of 307.1 hours) as shown in Figure 4-18. At approximately 10:08 (elapsed time of 309.1 hours), a pressure surge reached an average of +16 inwc, which activated a system safety interlock. As a result of the safety interlock, feeding was automatically stopped and after 10 seconds, air to the film cooler (AF1), cameras (AF2 and AF3) and argon bubblers (FT-Ar-1 and FT-Ar-2) were shut off by the control software. The pressure in the melter dropped to an average of -20 inwc (Figure 4-18). It should be noted that the safety interlock and subsequent actions are unique to this system and are not prototypic of DWPF operations. An attempt was made to re-establish nominal conditions; however, at 10:42 the off-gas system blower started malfunctioning, which was thought to be caused by feed material in the off-gas line. The blower was replaced and to prevent a future failure, a 55-gallon poly drum was attached to the off-gas line in between the melter and blower to collect condensate and particulate.

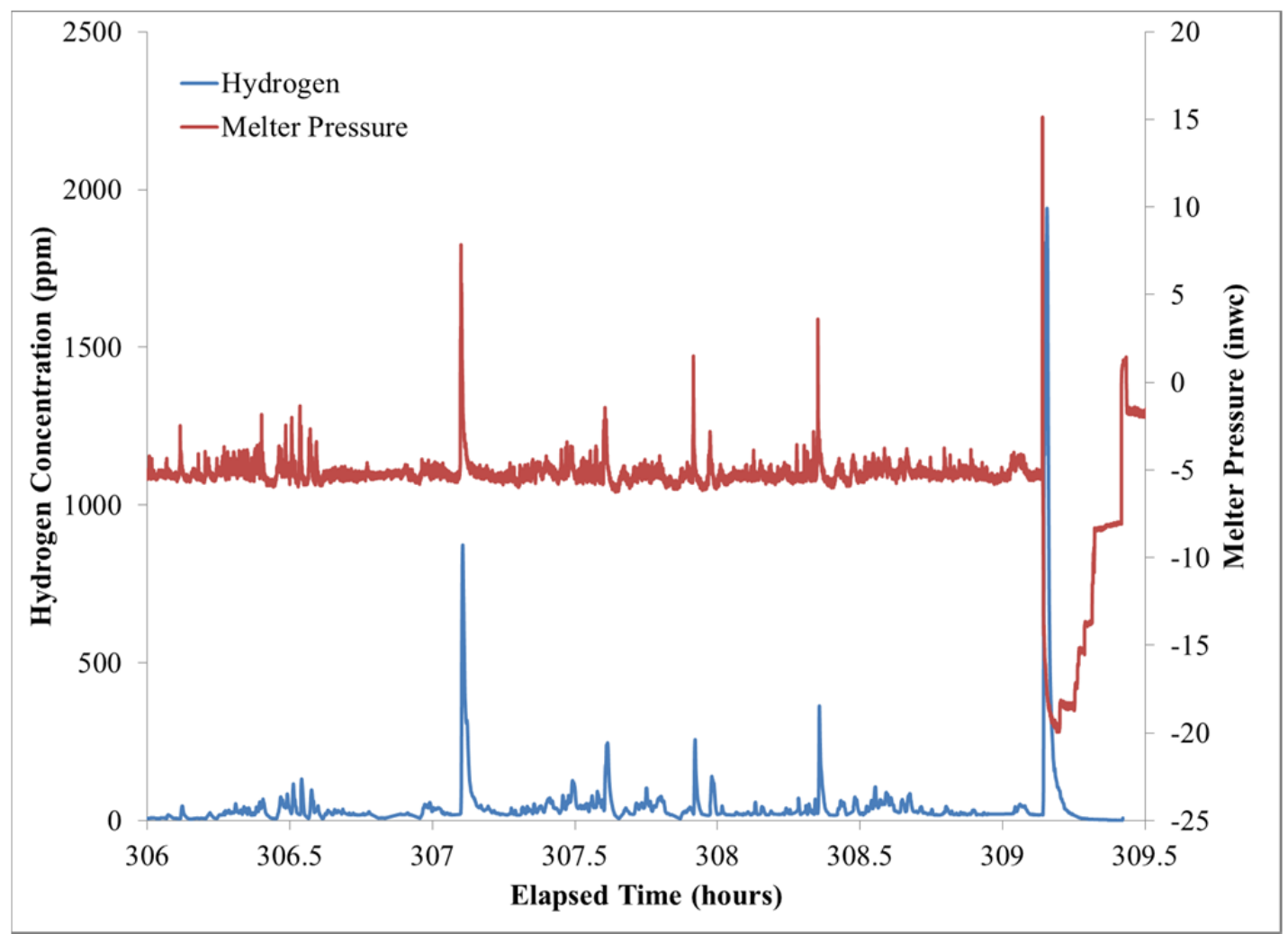

Figure 4-18. Melter pressure (PT1) before and after +16 inwc pressure surge.

Air and argon flows to the melter twenty four hours prior to this event were quite stable as shown in Table 4-10. During this time feed rate was increased from $\sim 199-250 \mathrm{~g} / \mathrm{min}$, which was not unusual compared to feed rates used at the beginning of testing during turnover. The average melt pool temperature was $996^{\circ} \mathrm{C}$ with a minimum temperature of $869^{\circ} \mathrm{C}$, which was somewhat low compared to other times during testing. 
Table 4-10. Conditions in Melter Prior to Surge

\begin{tabular}{lccc}
\hline Parameter & Average & Minimum & Maximum \\
\hline Feed Rate $(\mathrm{g} / \mathrm{min})$ & --- & 199 & 251 \\
\hline Vapor Space Temperature $\left({ }^{\circ} \mathrm{C}\right)$ & 731 & 641 & 764 \\
\hline Melt Pool Temperature $\left({ }^{\circ} \mathrm{C}\right)$ & 996 & 869 & 1036 \\
\hline Argon Flow (scfm) & 0.5 & --- & --- \\
\hline Film Cooler Air Flow $(\mathrm{scfm})$ & 16 & --- & --- \\
\hline Purge Air Flow (scfm) & $\sim 0$ & --- & --- \\
\hline Camera 1 Air Flow $(\mathrm{scfm})$ & 8 & --- & --- \\
\hline Camera 2 Air Flow, Inlet $(\mathrm{scfm})$ & 8 & --- & --- \\
\hline Camera 2 Air Flow, Outlet $(\mathrm{scfm})$ & 7 & --- & --- \\
\hline
\end{tabular}

One difference that should be noted is the feed itself; $125 \%$ stoichiometry feed was used during melter turnover. Visually, the $125 \%$ and $100 \%$ melter feeds were very different during mixing, which was expected based on the consistency measurements for the SRAT products; $15.2 \mathrm{cP}$ for the $125 \%$ stoichiometry feed versus $5.4 \mathrm{cP}$ for the $100 \%$ stoichiometry feed. ${ }^{36,37}$ During testing, the as-received $125 \%$ melter feed was described as being "very thick", while the $100 \%$ feed was described as being "thin and watery," which was also confirmed by the video recorded from Camera 1 during the surge. Prior to the surge a large vent hole was observed near one of the bubblers (Figure 4-19a) and the +16 inwc pressure spike occurred as melter feed flooded the entire vent hole (Figure 4-19b).

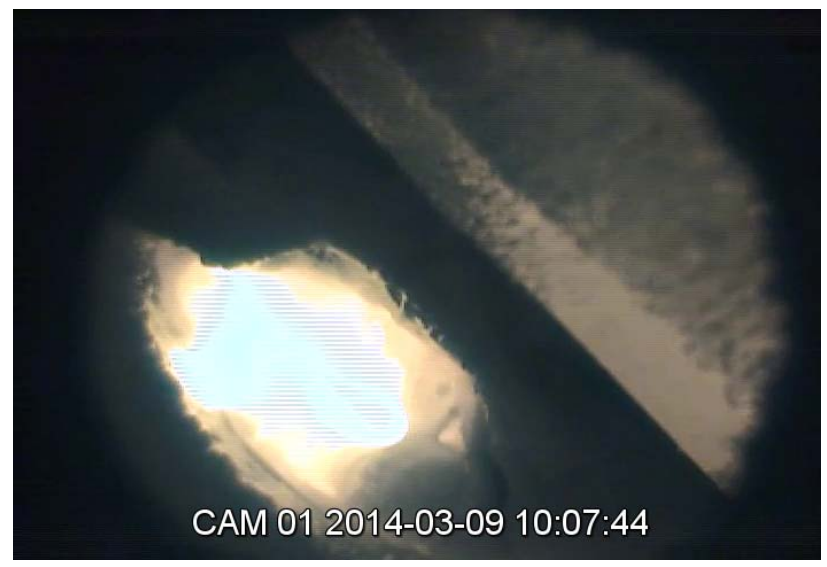

(a)

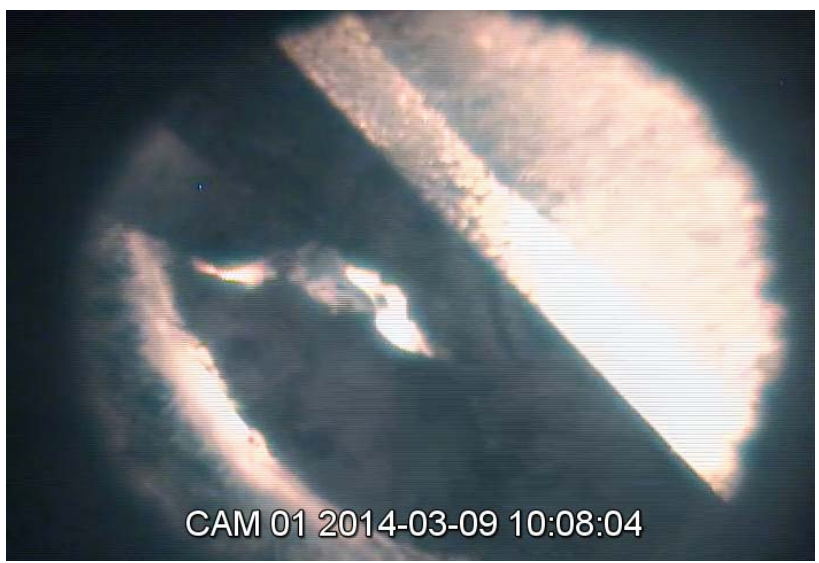

(b)

Figure 4-19. Images of cold cap and vent hole pre-surge (a) and during +16 inwe surge (b).

At this time, hydrogen concentration also increased to $\sim 2000 \mathrm{ppm}$. A comparison of hydrogen concentration and pressure is shown in Figure 4-18. Each spike in hydrogen concentration has a corresponding spike in pressure, which is characteristic of surges in the melter. Unfortunately the view from Camera 2 was unclear and it was not possible to see if a "pool" of feed had been forming in the center of the melter over time. Several of the pressure surges leading up to this event were also viewed and feed entered the vent hole in each case; however, the amount of feed was much less in these occurrences. Intuitively, the $125 \%$ stoichiometry feed should have been thinner as compared to the $100 \%$ feed due to increased acid; however, the thick consistency of the $125 \%$ stoichiometry SRAT product was also observed during recent SRAT runs performed at SRNL. ${ }^{33}$ It is possible that the thin consistency of the $100 \%$ feed coupled with the low melt pool temperature created the ideal conditions for this massive 
surge to occur in the melter. Lower melt pool temperatures are conducive to a more rigid cold cap. Had the melt pool temperature been higher, it is possible that there would not have been as much potential for "pooling" of the melter feed, which caused the surge as the significant amount of feed entered the vent hole.

At approximately 23:27 on March 9, 2014, feeding was restarted with the 100\% stoichiometry feed at $\sim 80$ $\mathrm{g} / \mathrm{min}$ and the argon bubbler rate was increased to $\sim 0.5 \mathrm{scfm}$ per bubbler at approximately 1:45 on March 10, 2014. By 13:51, the average feed rate was $225 \mathrm{~g} / \mathrm{min}$. The average melt pool temperature was $1011^{\circ} \mathrm{C}$, which is $15^{\circ} \mathrm{C}$ higher than the average temperature prior to the +16 inwc surge. Air flow and argon flows were also stable. During this instance of feeding the $100 \%$ stoichiometry feed at $45 \mathrm{wt} \%$ total solids, only one instance of positive pressure was observed $(\sim 1$ inwc). The cold cap appeared to be uniform and somewhat fluid, which is significantly different than cold cap prior to the +16 inwc surge, which was raised and rigid around the vent hole. The higher melt pool temperatures during this instance of the $45 \mathrm{wt} \%$ total solids testing could have prevented a thick cold cap from forming, thus reducing the chance for feed to pool in the center of the melter and cause a significant surge to occur. Based on a discussion with the customer, the total solids target of the $100 \%$ stoichiometry feed was reduced to 42 $\mathrm{wt} \%$ in order to make comparisons to surge testing that had been completed in 2010 with nitric-formic acid feed.

\subsubsection{Surge Testing (Bubbled at 42 wt\% total solids)}

At 17:33 on March 10, 2014, the feed was further diluted to $42 \mathrm{wt} \%$ total solids. After a subsequent heater failure and replacement (19:40 - 2:00 on March 11,2014), feeding was restarted at 4:31 on March 11,2014 (elapsed time of 351.5 hours) with a bubbling rate of $\sim 0.5 \mathrm{scfm}$ per bubbler and continued under nominal conditions until March 15, 2014 at 9:40.

Average values of vapor space temperature, melt pool temperature and argon flow during this time are shown in Table 4-11. While the average argon flow was $\sim 0.5 \mathrm{scfm}$ per bubbler, there were instances during the test in which the bubbling rate was lowered in order to increase the melt pool temperature.

Table 4-11. Melter Conditions During Bubbled Surge Testing

\begin{tabular}{ccc}
$\begin{array}{c}\text { Average Vapor Space } \\
\text { Temperature }\left({ }^{\circ} \mathrm{C}\right)\end{array}$ & $\begin{array}{c}\text { Average Melt Pool } \\
\text { Temperature }\left({ }^{\circ} \mathrm{C}\right)\end{array}$ & $\begin{array}{c}\text { Average Argon Flow } \\
(\mathbf{s c f m}) \text { per bubbler }\end{array}$ \\
\hline 720 & 996 & 0.5 \\
\hline
\end{tabular}

Nominal air flows to the melter were held constant. ${ }^{\mathrm{t}}$ Feed rate was varied in the range of $72-270 \mathrm{~g} / \mathrm{min}$ as shown in Figure 4-20. ${ }^{\mathrm{u}}$ Feed line blockages are noted by a feed rate value of $0 \mathrm{~g} / \mathrm{min} .^{\mathrm{v}}$ Melter pressure and hydrogen concentration are shown for the $\sim 4$ days of bubbled surge testing in Figure 4-21. Positive melter pressures were not observed until the elapsed test time had reached approximately 411 hours, the highest of which reached approximately +8 inwc. Hydrogen concentrations for these positive pressures were in the range of $\sim 300-700 \mathrm{ppm}$. Camera 1 video again confirmed that these surges were caused by feed flooding into the vent hole. The cold cap prior to the largest surge $(+8$ inwc) had a raised and rigid appearance (Figure 4-22) around the vent hole similar to the cold cap prior to the +16 inwc surge. Had

\footnotetext{
${ }^{\mathrm{t}} \mathrm{AF} 1($ Film Cooler) $\approx 17 \mathrm{scfm}, \mathrm{AF} 2($ Camera 1$) \approx 8 \mathrm{scfm}, \mathrm{AF} 3$ (Camera 2 Inlet) $\approx 8 \mathrm{scfm}$, AF4 (Camera 2 Outlet) $\approx 7 \mathrm{scfm}$ and AF5 (Melter Stoke Air) $\approx 0$ scfm.

${ }^{\mathrm{u}}$ Feed rate was estimated by using a conversion factor of 3.6 for the feed pump RPM values listed in the laboratory notebooks (SRNL-NB-2013-00020 and SRNL-NB-2014-00007).

${ }^{v}$ Feed line blockages occurred throughout testing and are only mentioned in this section due to the feed rate points of $0 \mathrm{~g} / \mathrm{min}$ in Figure 4-20.
} 
the average melt pool temperature been comparable to the DWPF operating temperature, it is possible that some of the surges could have been avoided in this system.

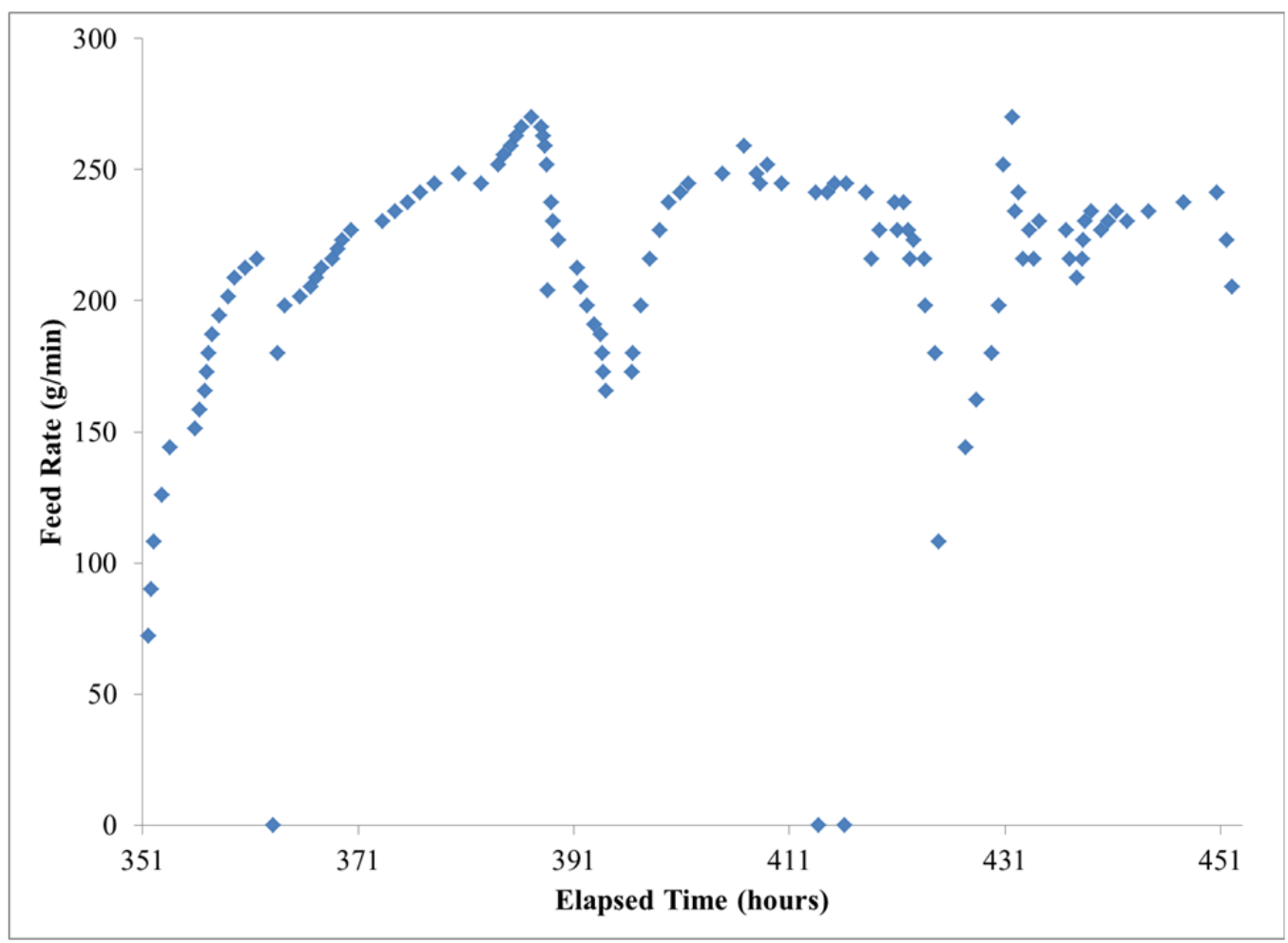

Figure 4-20. Feed rates during bubbled surge testing.

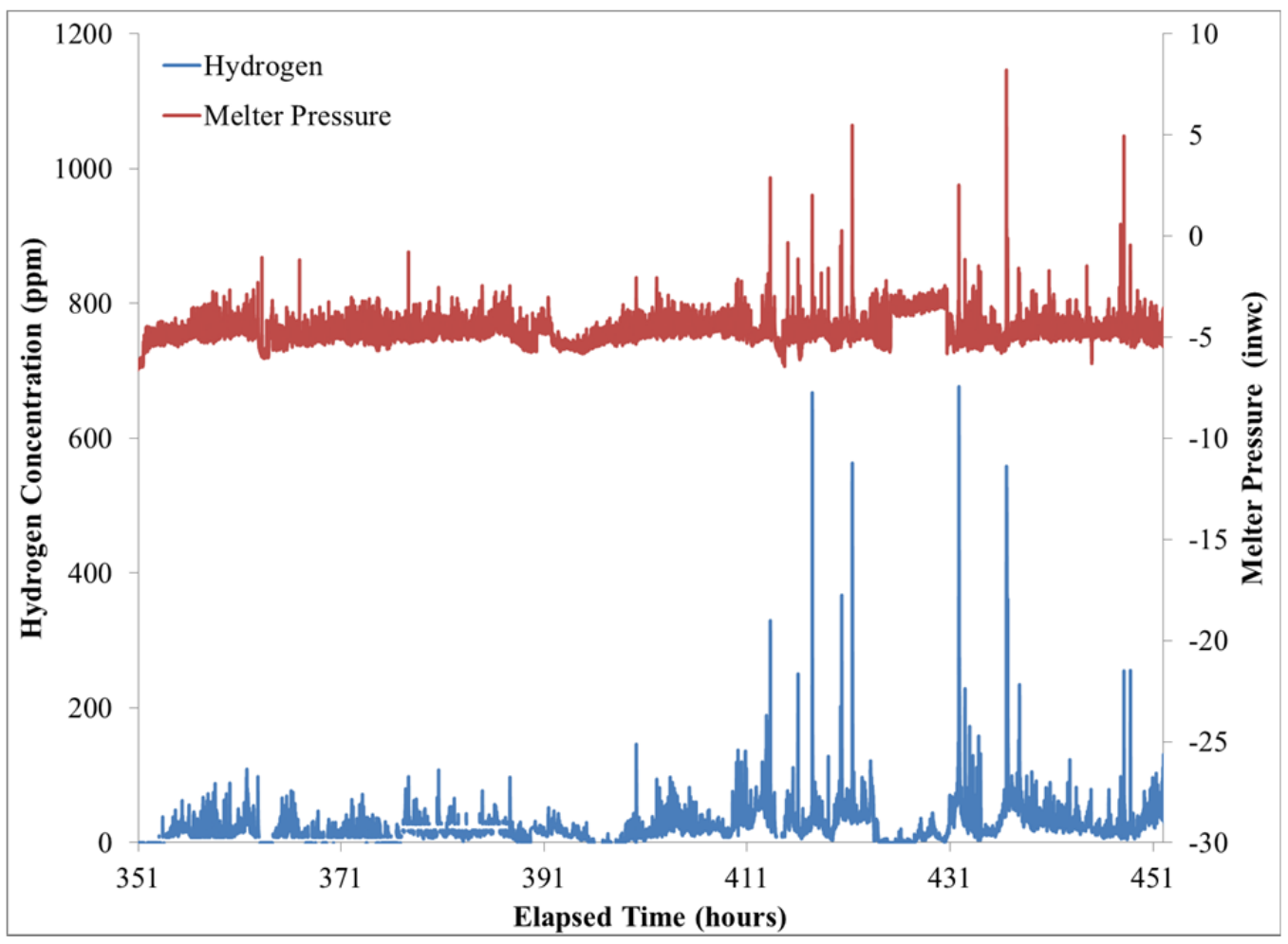

Figure 4-21. Melter pressure and hydrogen concentration during bubbled surge testing. 


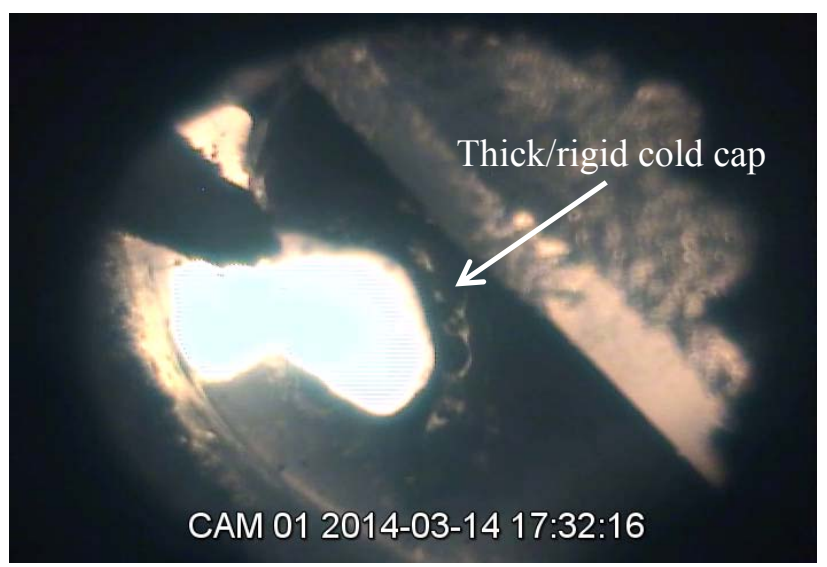

Figure 4-22. Image of the cold cap and vent hole prior to the +8 inwe surge.

\subsubsection{Surge Testing (Non-bubbled)}

Non-bubbled surge testing was initiated with the $100 \%$ stoichiometry feed at a $42 \mathrm{wt} \%$ total solids target on March 15, 2014 at approximately 13:24 with an argon rate of $\sim 0.003$ per bubbler $\left(\sim 0.006 \mathrm{scfm}\right.$ total). ${ }^{\mathrm{w}}$ Average values of vapor space temperature, melt pool temperature and argon flow during this time are shown in Table 4-12.

Table 4-12. Melter Conditions During Non-Bubbled Surge Testing

\begin{tabular}{ccc}
$\begin{array}{c}\text { Average Vapor Space } \\
\text { Tempe rature }\left({ }^{\circ} \mathbf{C}\right)\end{array}$ & $\begin{array}{c}\text { Average Melt Pool } \\
\text { Tempe rature }\left({ }^{\circ} \mathbf{C}\right)\end{array}$ & $\begin{array}{c}\text { Average Argon Flow } \\
(\mathbf{s c f m}) \text { per bubbler }\end{array}$ \\
\hline 713 & 1067 & 0.003 \\
\hline
\end{tabular}

Nominal air flows to the melter were held constant. ${ }^{\mathrm{x}}$ Feed rate was varied in the range of $105-165 \mathrm{~g} / \mathrm{min}$ as shown in Figure 4-23. ${ }^{y}$ Melter pressure and hydrogen concentration are shown for the 1 day of nonbubbled testing in Figure 4-24. The only positive pressure ( +5 inwc) occurred at approximately 465 hours with a corresponding peak in hydrogen at $\sim 70 \mathrm{ppm}$. The view from Camera 1 did not show any obvious conditions in the melter that would have caused a positive surge. While there was liquid feed on the surface of the cold cap, there was not a visible vent hole that feed was entering as shown in Figure 4-25. The view from Camera 2 was unclear, but there also did not appear to be a vent hole.

\footnotetext{
${ }^{\mathrm{w}}$ During non-bubbled conditions, a minimal bubbling rate was maintained in order to reduce the risk of plugging the bubbler ports.

${ }^{\mathrm{x}} \mathrm{AF} 1($ Film Cooler) $\approx 16 \mathrm{scfm}, \mathrm{AF} 2$ (Camera 1) $\approx 8 \mathrm{scfm}, \mathrm{AF} 3$ (Camera 2 Inlet) $\approx 8 \mathrm{scfm}$, AF4 (Camera 2 Outlet) $\approx 7 \mathrm{scfm}$ and AF5 (Melter Stoke Air) $\approx 0.4 \mathrm{scfm}$.

${ }^{\mathrm{y}}$ Feed rate was estimated by using a conversion factor of 3.6 for the feed pump RPM values listed in the laboratory notebooks (SRNL-NB-2013-00020 and SRNL-NB-2014-00007).
} 
SRNL-STI-2014-00157

Revision 0

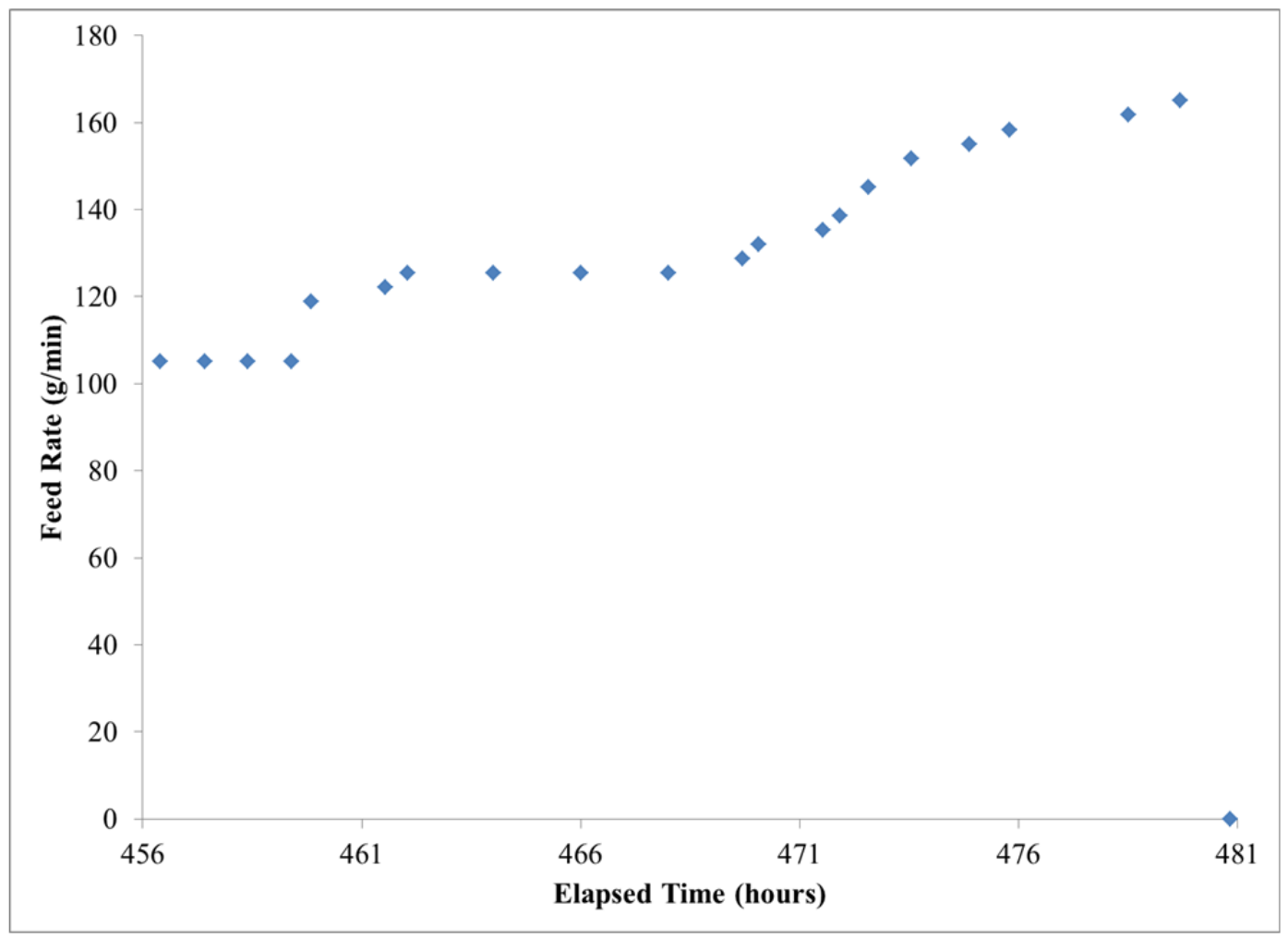

Figure 4-23. Feed rates during non-bubbled surge testing.

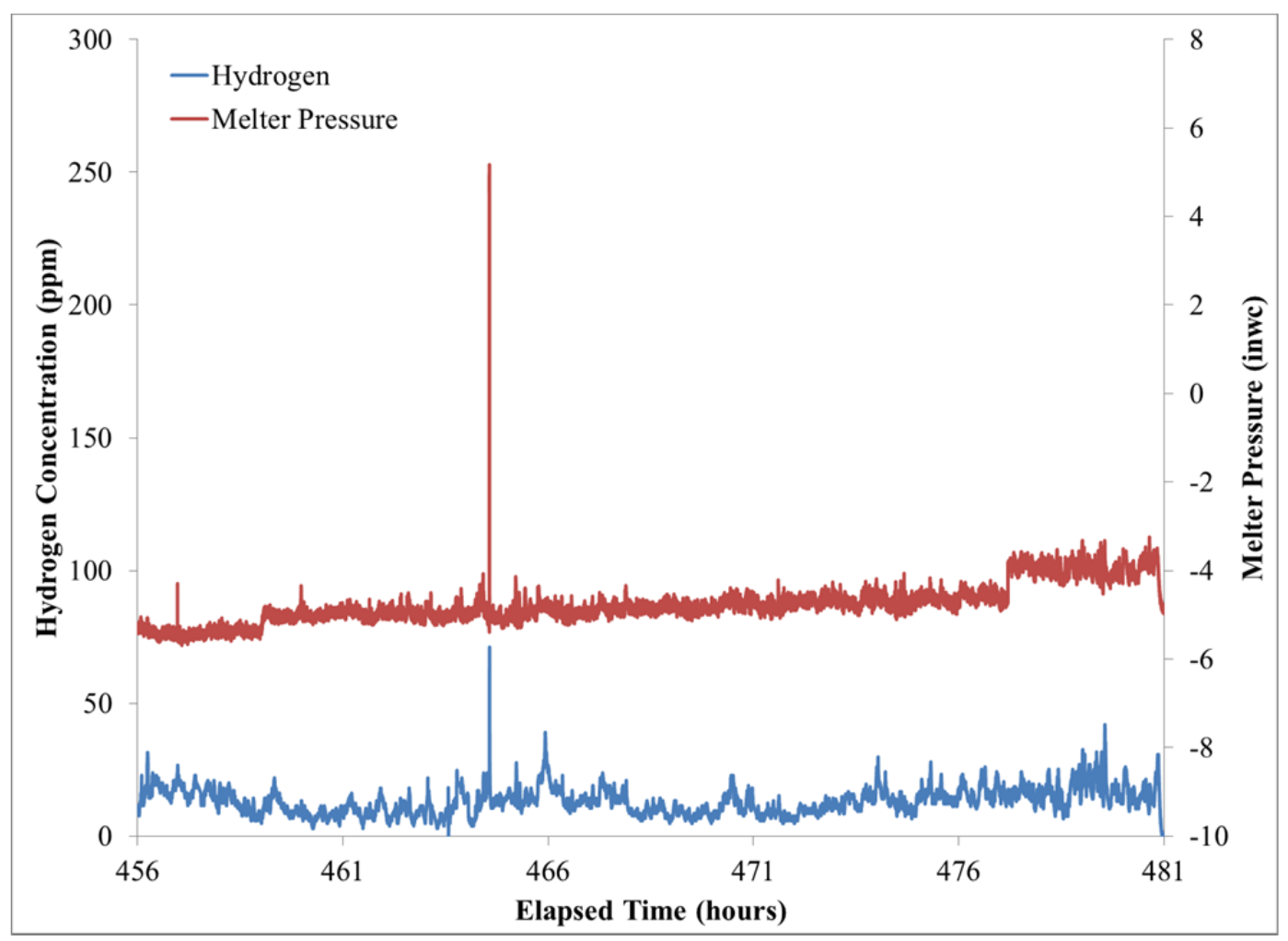

Figure 4-24. Melter pressure and hydrogen concentration during non-bubbled surge testing. 
SRNL-STI-2014-00157

Revision 0

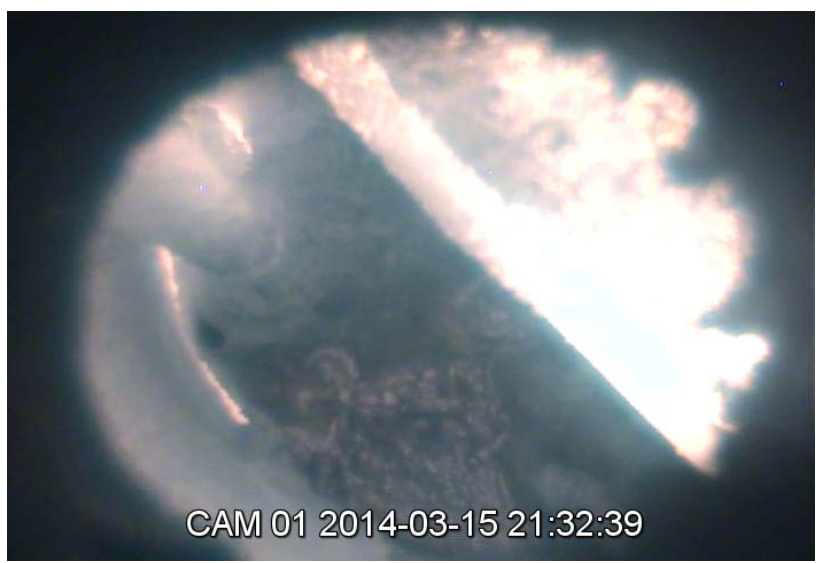

Figure 4-25. Image of the cold cap prior to the +5 inwe surge during non-bubbled conditions.

\subsection{0\% Stoichiometry Melter Feed with Antifoam Spike (Non-bubbled)}

Feeding was initiated on March 16, 2014 at $\sim 16: 48$ with an argon bubbling rate of $\sim 0.003 \mathrm{scfm}$ per bubbler. $^{z}$ Approximately three times $(\sim 3 \mathrm{X})$ the nominal amount of Antifoam 747 was added to each batch $(0.7 \mathrm{~kg}$ as shown in Table 3-6 of Section 3.2) and the feed was diluted to a target total solids of 45 $\mathrm{wt} \%$. Visually, the consistency of this antifoam spiked melter feed was reduced as compared to the $100 \%$ stoichiometry melter feed without excess antifoam. As the feed was mixing in the feed pot, a considerable amount of foam was generated as shown in Figure 4-26; however, no foaming was observed inside of the melter. It should be noted that foaming from excessive antifoam additions has occurred during previous testing.

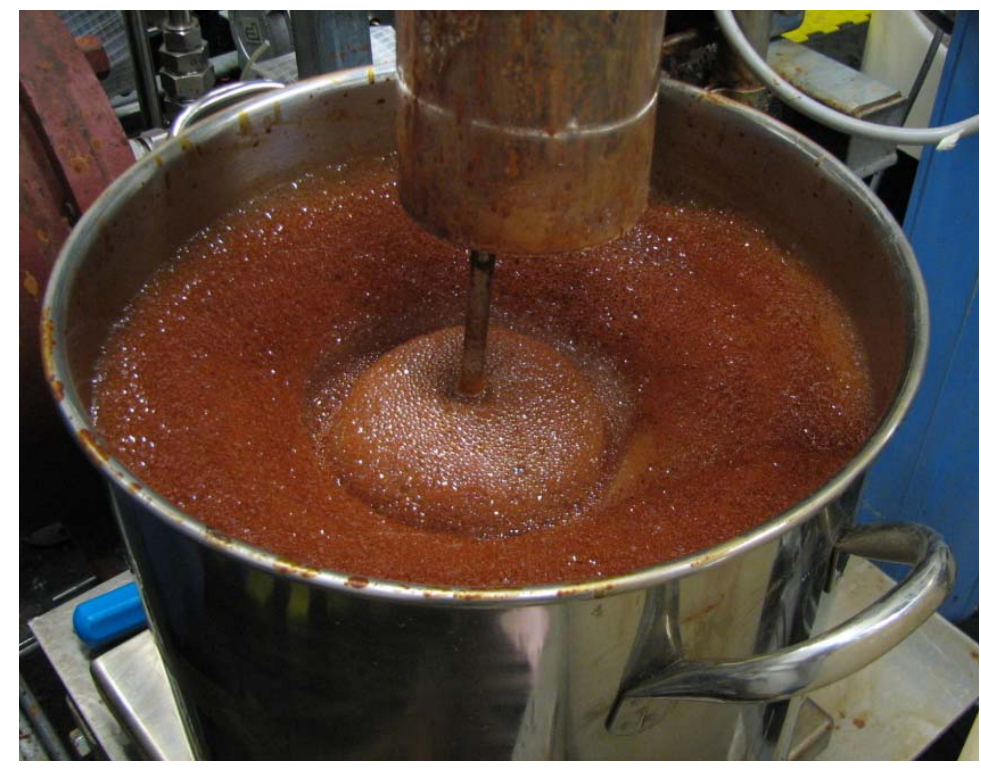

Figure 4-26. Foamy melter feed.

The $100 \%$ stoichiometry melter feed with the antifoam spike appeared very fluid in the Camera 1 view and despite constant feeding at an average rate of $68-194 \mathrm{~g} / \mathrm{min}$ for at least 10 hours, the cold cap remained light in color and cracked, which is an indication of underfeeding (Figure 4-27).

\footnotetext{
${ }^{\mathrm{z}}$ During non-bubbled conditions, a minimal bubbling rate was maintained in order to reduce the risk of plugging the bubbler ports.
} 

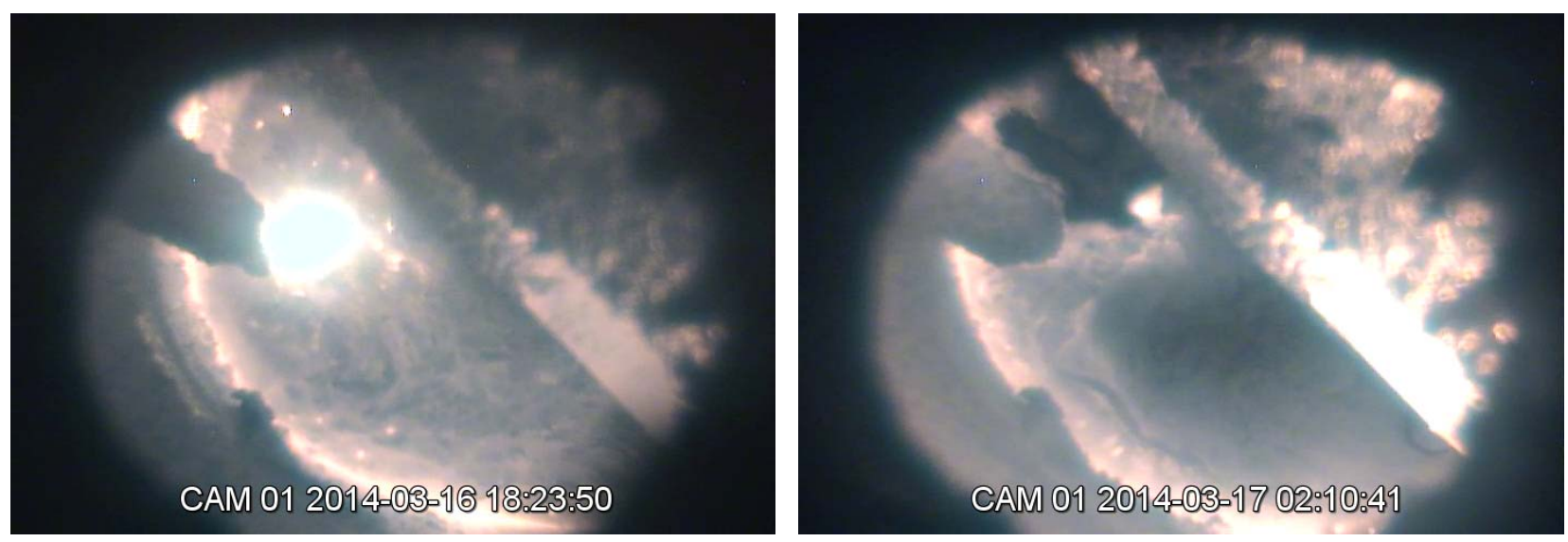

Figure 4-27. Cold cap images during the $\sim 3 X$ antifoam spike.

The correlation between the feed pump rotations per minute (RPM) and the calculated feed rates ${ }^{\text {aa }}$ was extremely inconsistent for this feed, which was related to the foam present in the feed pot. In one instance the calculated feed rate for 56 RPM was $152 \mathrm{~g} / \mathrm{min}$, while a calculation at a later time resulted in a feed rate of $191 \mathrm{~g} / \mathrm{min}$. Air entrained in the feed caused there to be less feed being fed to the melter, which resulted in underfeeding even though sufficiently high pump speeds were being used. During this time a sufficient cold cap could not form.

An attempt was made to conduct the first $\sim 700^{\circ} \mathrm{C}$ steady state test at $4: 30$ on March 17 ; however, the vapor space temperature dropped by more than $30^{\circ} \mathrm{C}$ at the end of the two-hour period and the feed rate was inconsistent. By 8:00, the vapor space temperatures were still not steady even though no changes had been made to the system since 3:00. Based on the difficulties with the steady state testing, a decision was made by the technical lead to reduce the antifoam spike to two times $(\sim 2 \mathrm{X})$ the nominal amount per batch (0.4 kg as shown in Table 3-6 of Section 3.2). The total solids target remained at $45 \mathrm{wt} \%$. Foam was still present in the feed pot, but to a lesser extent than the $\sim 3 \mathrm{X}$ antifoam spiked melter feed.

\subsubsection{Steady State Vapor Space Testing ( 2X Antifoam Spike, Non-Bubbled)}

Steady state testing with the $100 \%$ stoichiometry feed ( $\sim 2 \mathrm{X}$ antifoam spike and $45 \mathrm{wt} \%$ total solids) with an argon bubbling rate of $\sim 0.002 \mathrm{scfm}$ per bubbler began on March 17 at 12:12 and was completed on March 19 at $0: 42 .^{\text {bb }}$ It should be noted that the $700^{\circ} \mathrm{C}$ vapor space temperature test was repeated on March 20 since the initial test had been conducted with the $\sim 3 \mathrm{X}$ antifoam spiked feed. A summary of the primary test conditions for each vapor space temperature test are shown in Table 4-13. ${ }^{c c}$ The initial temperature was $\sim 604^{\circ} \mathrm{C}$ and the feed rate, vapor space heater output and air purge were incrementally adjusted to decrease the vapor space temperature to $\sim 293^{\circ} \mathrm{C}$. Additional purge air in the range of 19-34 $\mathrm{scfm}$ was required to achieve vapor space temperatures below $\sim 519^{\circ} \mathrm{C}$. Feed rates in the range of 36-103 $\mathrm{g} / \mathrm{min}$ were used, which is comparable to previous non-bubbled steady state tests. As previously mentioned, the correlation between pump RPM and calculated feed rate was not very consistent for this feed, which is also evident in Figure 4-28. For all other feeds, the linear fit of feed rate and vapor space temperature had a relatively high $\mathrm{R}^{2}$ value $(>0.89)$; however, the value for this feed was only 0.8 . A comparison of the actual and calculated feed rates is shown in Figure 4-29. The $722^{\circ} \mathrm{C}$ test was repeated at a later date, which could be the cause for the large deviation between the two rates. Images of the cold cap throughout steady state testing are shown in Figure 4-30 and Figure 4-31. Compared to images from the previous non-bubbled tests, there appears to be much more cold cap coverage, as there is no additional

\footnotetext{
${ }^{\text {aa }}$ Feed rate was calculated by the change in mass of the feed scale per unit time.

${ }^{\mathrm{bb}}$ During non-bubbled conditions, a minimal bubbling rate was maintained in order to reduce the risk of plugging the bubbler ports.

${ }^{\mathrm{cc}}$ The melter conditions for the repeated $700^{\circ} \mathrm{C}$ steady state test is presented.
} 
orange glow from the glass melt besides the vent hole. There was no evidence of overfeeding as no significant deviations in melt pool temperature were observed. The average glass pool temperature was in the range of $1052-1097^{\circ} \mathrm{C}$ through testing.

Table 4-13. Antifoam Spike Non-Bubbled Steady State Vapor Space Temperature Test Conditions

\begin{tabular}{|c|c|c|c|}
\hline $\begin{array}{c}\text { Average Vapor } \\
\text { Space Temperature } \\
\left({ }^{\circ} \mathrm{C}\right) \\
\end{array}$ & $\begin{array}{c}\text { Ave rage Glass } \\
\text { Pool Tempe rature } \\
\left({ }^{\circ} \mathrm{C}\right)\end{array}$ & $\begin{array}{c}\text { Average Film } \\
\text { Cooler Flow } \\
\text { (scfm) }\end{array}$ & $\begin{array}{c}\text { Average Melter } \\
\text { Air Purge } \\
\text { (scfm) }\end{array}$ \\
\hline 722 & 1097 & 16 & 0 \\
\hline 604 & 1071 & 16 & 0 \\
\hline $519 *$ & 1066 & 16 & 0 \\
\hline $397 *$ & 1052 & 16 & 19 \\
\hline $323^{*}$ & 1057 & 10 & 28 \\
\hline 293 & 1066 & 6 & 34 \\
\hline $\begin{array}{c}\text { Average Vapor } \\
\text { Space Temperature } \\
\left({ }^{\circ} \mathrm{C}\right)\end{array}$ & $\begin{array}{c}\text { Average Feed } \\
\text { Rate } \\
\text { (g/min) } \\
\end{array}$ & $\begin{array}{l}\text { Average Melter } \\
\text { Pressure (inwc) }\end{array}$ & $\begin{array}{c}\text { Average Vapor } \\
\text { Space Output } \\
\text { (volts) }\end{array}$ \\
\hline 722 & 103 & -3 & 128 \\
\hline 604 & 122 & -5 & 93 \\
\hline 519 & 59 & -5 & 21 \\
\hline 397 & 49 & -5 & 8 \\
\hline 323 & 39 & -4 & 8 \\
\hline 293 & 36 & -3 & 8 \\
\hline
\end{tabular}

* During this time there were issues with T11 and T12, so the average vapor space temperature during this time was taken from the thermocouple with the steadier readings. 


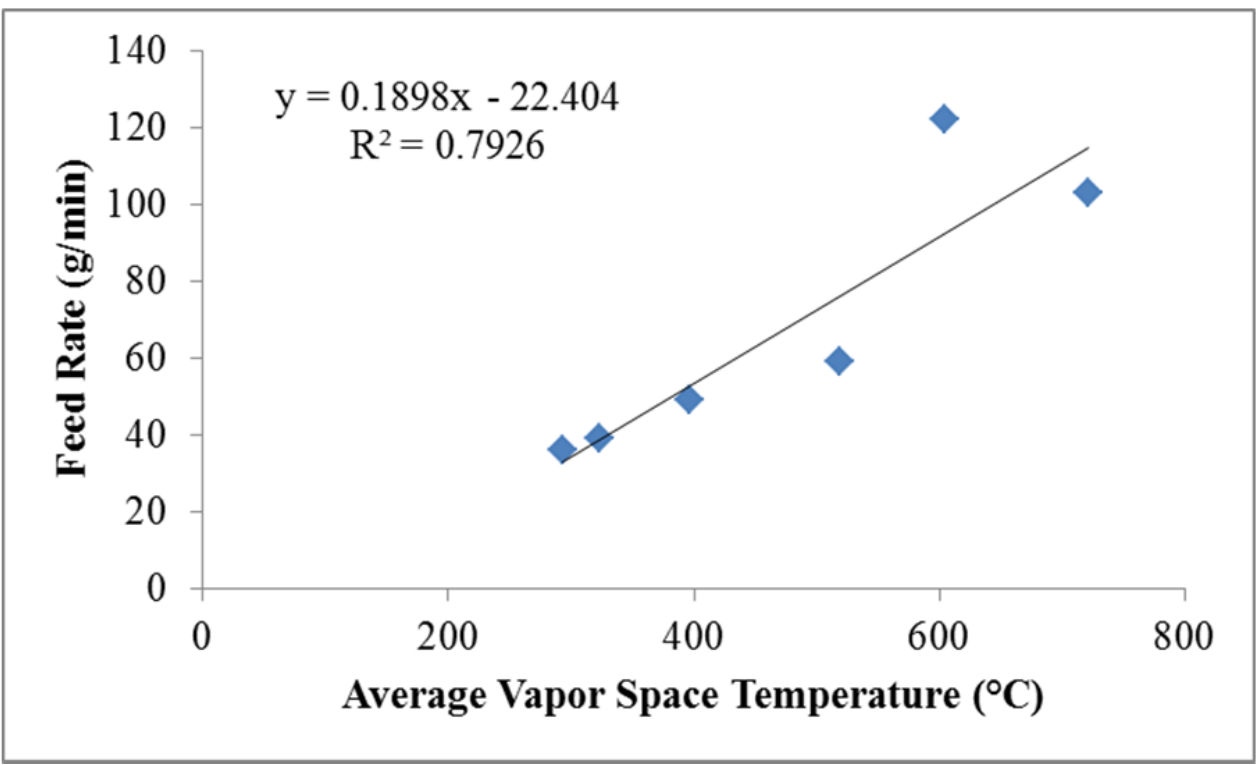

Figure 4-28. $100 \%$ stoichiometry ( $2 \mathrm{X}$ antifoam spike) non-bubbled feed rate as a function of vapor space temperature.

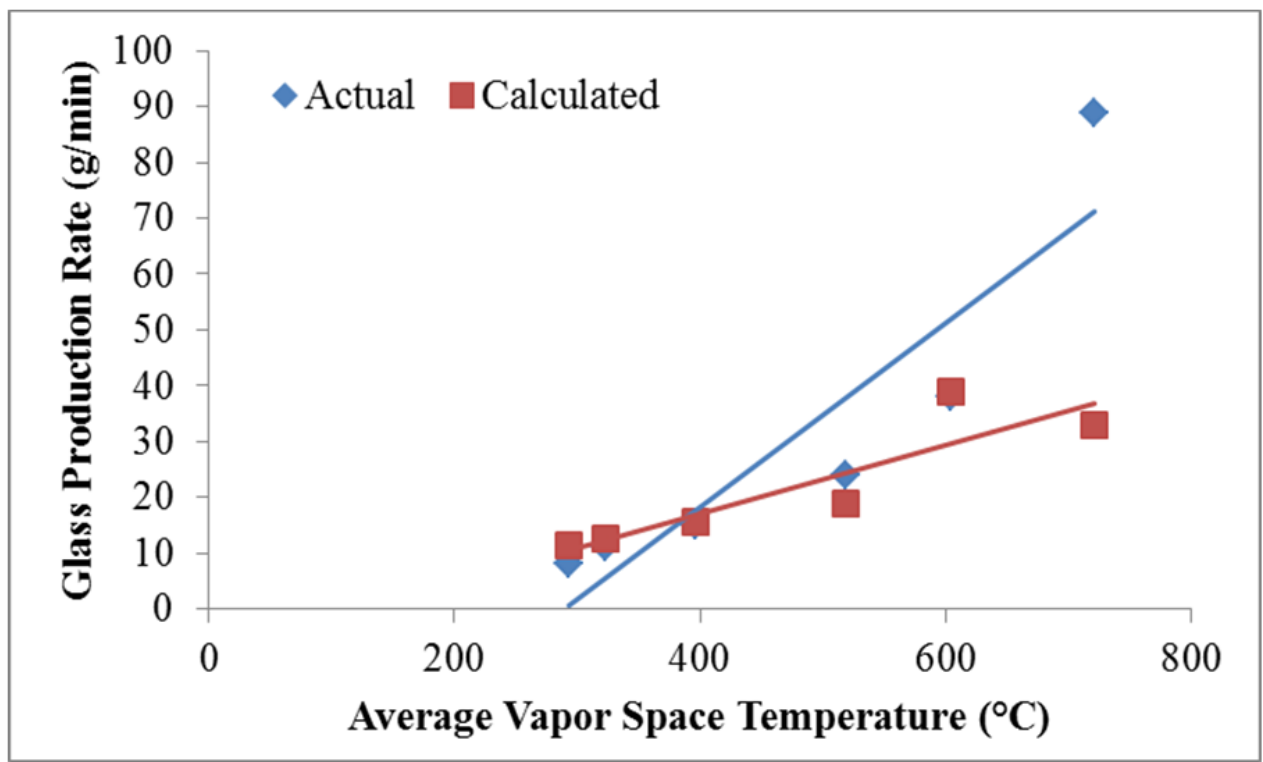

Figure 4-29. $100 \%$ stoichiometry ( $2 \mathrm{X}$ antifoam spike) non-bubbled condition glass production rates. 


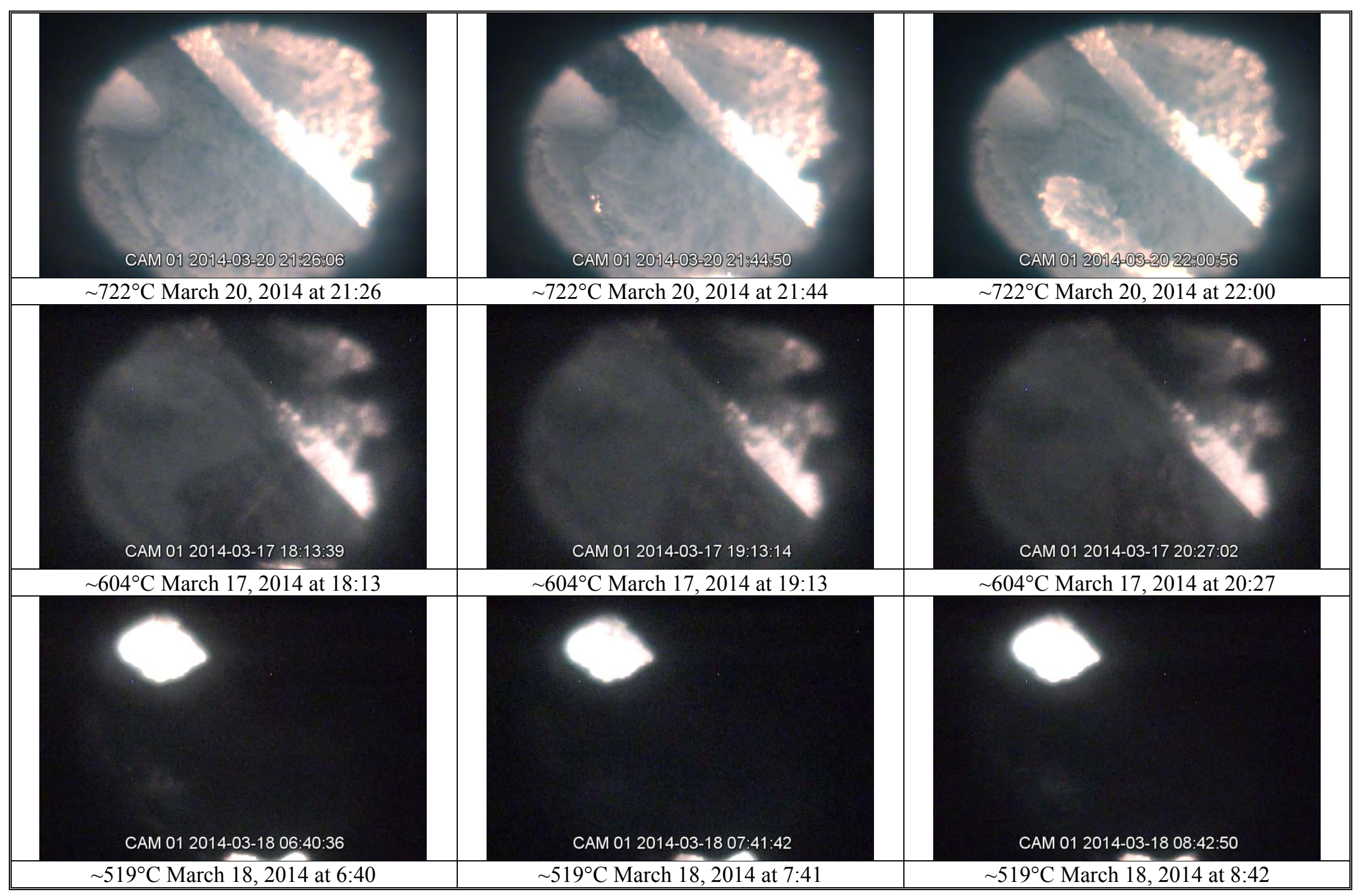

Figure 4-30. Cold cap images during the $100 \%$ stoichiometry ( $2 \mathrm{X}$ antifoam spike) non-bubbled testing. 


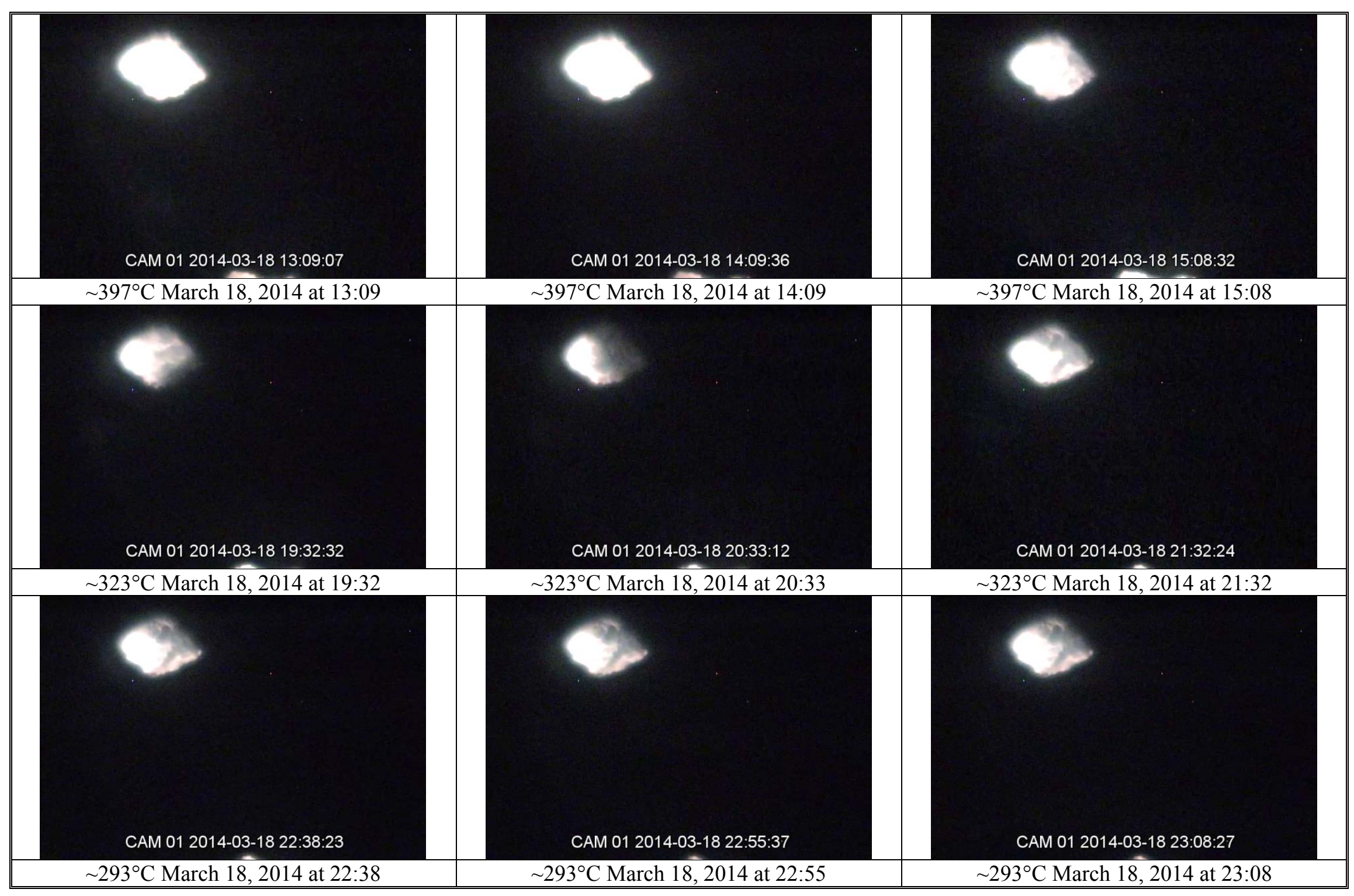

Figure 4-31. Cold cap images during the $100 \%$ stoichiometry ( $2 \mathrm{X}$ antifoam spike) non-bubbled testing. 


\subsection{Glass Production Rate}

Although melt rate was not one of the objectives of this alternate reductant melter testing, conditions used for Phase I and Phase II testing provide an opportunity to gain some insight into potential differences in melt rate or glass production rate. Therefore, the results are presented for information only. Since Phase I testing was limited in scope, only the non-bubbled, steady state testing points can be used for comparison with the Phase II data. At vapor space temperatures above $500^{\circ} \mathrm{C}$, a glass production rate in the range of $27-30 \mathrm{~g} / \mathrm{min}$ was achieved for the nitric-formic flowsheet and 31-44 g/min was attained for the nitric-glycolic flowsheet during steady state conditions as shown in Figure 4-32. It should be noted that the operation of the CEF is subjective, which can introduce a considerable amount of variation in any feed rate or melt rate data. In order to compare melt rate under similar conditions, both of these feeds should be further tested with the melt rate furnace (MRF) and analyzed with X-ray computed tomography (CT), which is a method that has been used successfully in the past for melt rate assessments for DWPF. ${ }^{54-56}$ The MRF testing and CT analysis techniques would eliminate much of the subjectivity that was introduced during these particular CEF tests, thus providing more un-biased melt rate data. Bubbled melt rate testing under nominal conditions using the CEF would also be of interest.

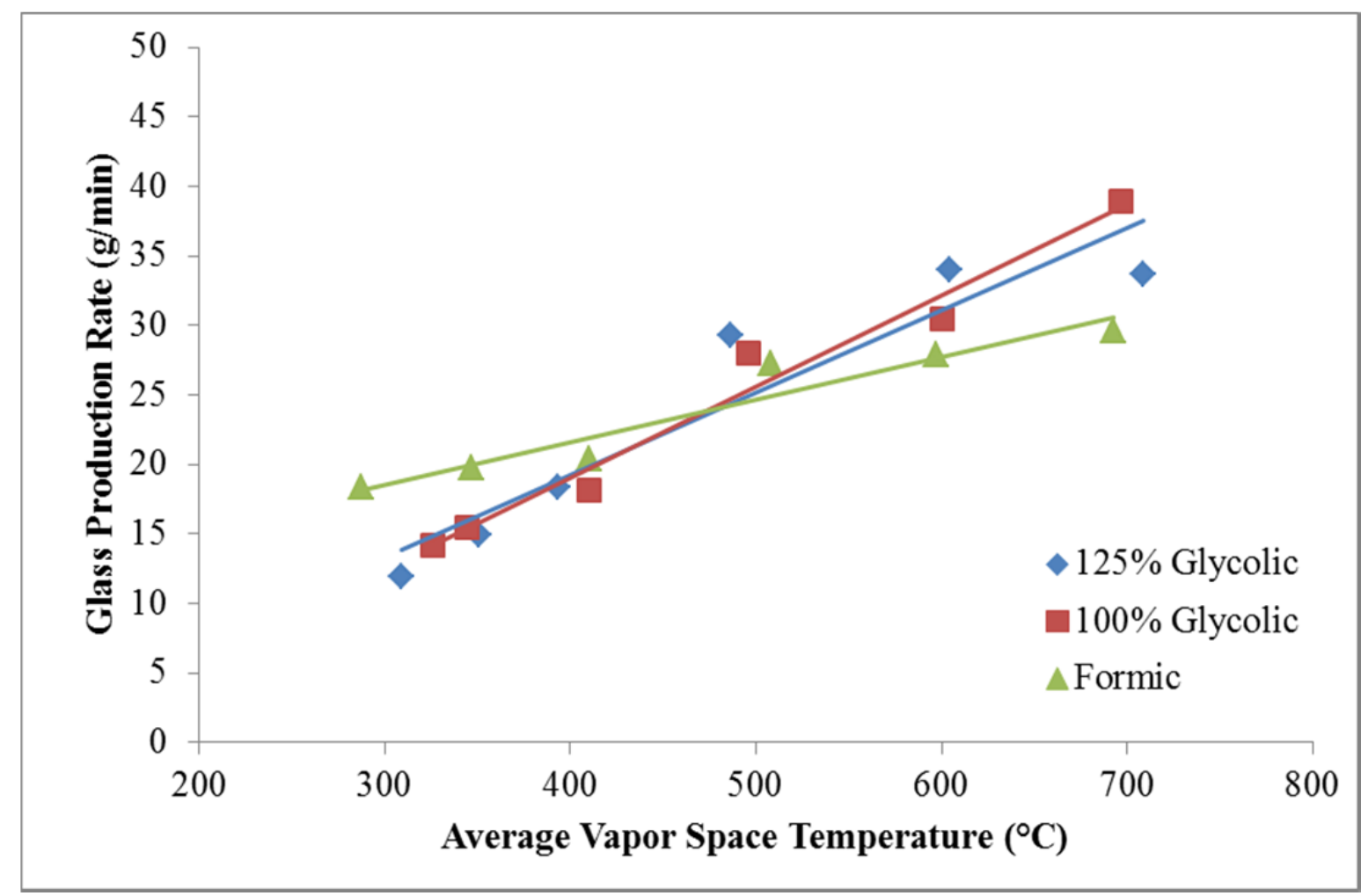

Figure 4-32. Comparison of non-bubbled glass production rates (calculated) as a function of vapor space temperature.

\subsection{Vessel Dimensional Documentation}

In support of future melter life assessments in terms of structural creep, the temperatures of the thermocouples that were welded to five of the support blocks were monitored and recorded throughout testing. ${ }^{57,58}$ Plots of the recorded temperatures are shown in the Appendix (Figure A-46 through Figure A-50). The average temperature was $568^{\circ} \mathrm{C}$ (standard deviation of $151^{\circ} \mathrm{C}$ ) with a maximum temperature of $893^{\circ} \mathrm{C}$. It is important to note that all of the measured support block temperatures were well below the $1093^{\circ} \mathrm{C}$ value that was used prior to Phase I testing to estimate melter life based on creep concerns. ${ }^{57,58}$ 
Prior to the start of Phase II testing, the melter vessel had been operated for approximately 385 hours total since 2010. Phase II testing resulted in an additional 672 hours, which brings the current total operational hours on the vessel to approximately 1057 hours. The recommended service life from the previous assessments was 1250 hours, thus if future scope requires use of the current CEF vessel, it is advised to perform measurements of the vessel and support tension rods and repeat the melter life assessment with the new data.

\subsection{Sample Analysis}

Samples were taken on a regular basis throughout testing. Feed samples were collected each time a new 30 gallon drum of SRAT product was prepared in to melter feed. Glass samples were pulled from the pour stream at $\sim 4$ hour intervals. Condensate samples were taken from the overflow tank in the OGCT recirculation line at $\sim 1$ hour intervals. The $25 \mu \mathrm{m}$ bag filters ${ }^{\mathrm{dd}}$ were removed from service when the discharge pressure dropped by $\sim 3$ psi. The bags were dried at $50^{\circ} \mathrm{C}$ and the solids were collected for analysis.

Sorbent tubes containing coconut shell granular activated carbon were placed in line between the melter and off-gas instrumentation in order to adsorb any organic species from the off-gas stream during portions of testing.

The complete sets of sample results are shown in the Appendix Table A-3 through Table A-53.

\subsubsection{Feed Analysis}

As fresh drums of Harrell SRAT product were opened, it was observed that a somewhat thick, lard-like material was present in the bottom of some of the drums as the contents were initially mixed with a paddle. ${ }^{e e}$ An image of this material from one of the as-received 100\% stoichiometry SRAT drums is shown in Figure 4-33. As the SRAT material was further stirred with a drum mixer, this material appeared to break down. It is likely that this material is organic and further analysis is planned. A suitable analytical approach is under development and results will be issued in a separate report.

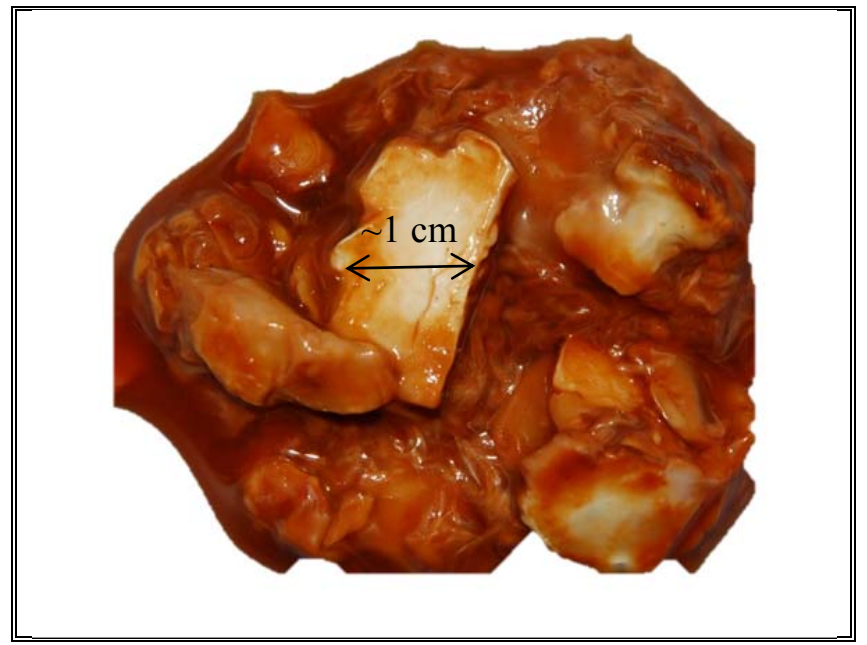

Figure 4-33. Image of lard-like material collected from a 100\% SRAT product drum.

\footnotetext{
${ }^{\mathrm{dd}}$ The filters are located after the recirculation pump, but before the booster pump on the condensate system, which protects the multistage pump used to supply water to the quencher.

${ }^{\mathrm{ee}}$ It is uncertain as to whether this material was only present in some drums or all of them.
} 
Average measured compositions of select melter feed samples is shown in Table 4-14. Some of the analytes were below the detection limit of the instrument and are noted by a result preceded by a " $<$." The relative standard deviation (\%RSD) values for a majority of the feed constituents are less than $8 \%$, which confirms that the melter feed was batched consistently. As mentioned previously, the consistency of the $100 \%$ stoichiometry melter feed was quite thin, which made it difficult to pull a representative sample for the total solids measurements. Thus, a majority of the measured values are slightly lower than the target values as shown in Table 4-15.

Table 4-14. Average Measured Melter Feed Composition (wt\% calcined at $1100^{\circ} \mathrm{C}$ )

\begin{tabular}{cccccccc}
\hline Component & $\mathbf{A l}$ & $\mathbf{B}$ & $\mathbf{B a}$ & $\mathbf{C a}$ & $\mathbf{C r}$ & $\mathbf{C u}$ & $\mathbf{F e}$ \\
\hline Average & 5.28 & 1.52 & 0.049 & 0.412 & 0.072 & 0.045 & 8.01 \\
\hline \%RSD & 7.0 & 7.7 & 5.7 & 6.2 & 5.6 & 14.6 & 7.2 \\
\hline Component & $\mathbf{K}$ & $\mathbf{L i}$ & $\mathbf{M g}$ & $\mathbf{M n}$ & $\mathbf{N a}$ & $\mathbf{N i}$ & $\mathbf{P}$ \\
\hline Average & 0.152 & 2.26 & 0.328 & 2.49 & 8.94 & 1.06 & $<0.100$ \\
\hline \%RSD & 5.2 & 4.9 & 7.3 & 7.6 & 3.3 & 6.4 & --- \\
\hline & & & & & & & \\
\hline Component & $\mathbf{S}$ & $\mathbf{S i}$ & $\mathbf{S n}$ & $\mathbf{T i}$ & $\mathbf{Z n}$ & $\mathbf{Z r}$ & \\
\hline Average & 0.113 & 23.0 & $<0.100$ & $<0.100$ & $<0.100$ & 0.109 & \\
\hline \%RSD & 9.4 & 4.8 & --- & --- & --- & 5.9 & \\
\hline
\end{tabular}

Table 4-15. Melter Feed Physical Data

\begin{tabular}{|c|c|c|c|c|c|c|}
\hline \multirow[b]{2}{*}{ Feed ID } & \multirow[b]{2}{*}{ Antifoam } & \multicolumn{2}{|c|}{ Total Solids } & \multirow{2}{*}{$\begin{array}{c}\text { Wt } \% \\
\text { Calcined }\end{array}$} & \multirow[b]{2}{*}{$\mathbf{p H}$} & \multirow{2}{*}{$\begin{array}{r}\text { Density } \\
\left(\mathrm{g} / \mathrm{cm}^{3}\right)\end{array}$} \\
\hline & & Target & $\begin{array}{l}\text { Average } \\
\text { Measured }\end{array}$ & & & \\
\hline $125 \%$ & nominal & $45 \%$ & $45.6 \%$ & $34.3 \%$ & 3.21 & 1.37 \\
\hline $100 \%$ & nominal & $45 \%$ & $43.1 \%$ & $32.9 \%$ & 3.82 & 1.34 \\
\hline $100 \%$ & nominal & $42 \%$ & $41.9 \%$ & $32.7 \%$ & 3.66 & 1.31 \\
\hline $100 \%$ & $\sim 3 X$ & $45 \%$ & $44.0 \%$ & $33.5 \%$ & 3.68 & 1.34 \\
\hline $100 \%$ & $\sim 2 \mathrm{X}$ & $45 \%$ & $43.0 \%$ & $32.4 \%$ & 3.62 & 1.34 \\
\hline
\end{tabular}

Average measured anions are shown in Table 4-16. For comparison, some of the melter feeds were measured by both analytical laboratories; PSAL and AD. The nitrate and oxalate were comparable; however, the glycolate values measured by AD were significantly higher (more representative) than PSAL. Other discrepancies include sulfate for the antifoam spiked feed and formate for the $125 \%$ and $100 \%$ stoichiometry feeds.

The measured TOC content of the various melter feeds were in the range of 14,098-17,548 ppm as shown in Table 4-17. The TOC values for the $100 \%$ stoichiometry antifoam spiked feeds were somewhat low as compared to feeds with the nominal antifoam amounts. Based on the foaminess of these melter feeds it was likely difficult to collect a representative sample, which could account for the low values. 
Table 4-16. Average Measured Melter Feed Anions (mg/Kg)

\begin{tabular}{|c|c|c|c|c|c|c|}
\hline Component & $\mathbf{C l}$ & $\mathrm{NO}_{3}$ & $\mathrm{C}_{2} \mathrm{H}_{3} \mathrm{O}_{3}$ & $\mathrm{SO}_{4}$ & $\mathrm{C}_{2} \mathrm{O}_{4}$ & $\mathrm{HCO}_{2}$ \\
\hline \multicolumn{7}{|c|}{ 125\% Stoichiometry (45\% total solids target) } \\
\hline Average (PSAL) & 289 & 63,917 & 36,783 & 1,256 & 1,248 & 1,597 \\
\hline$\%$ RSD & 5 & 7 & 5 & 25 & 9 & 36 \\
\hline Average (AD) & $<500$ & 67,341 & 43,250 & 1,282 & 1,218 & 764 \\
\hline$\%$ RSD & --- & 1 & 5 & 1 & 20 & 1 \\
\hline \multicolumn{7}{|c|}{$100 \%$ Stoichiometry (45\% total solids target) } \\
\hline Average (PSAL) & 311 & 61,450 & 26,600 & 1,405 & 928 & 2,413 \\
\hline$\%$ RSD & 4 & 2 & 2 & 0 & 3 & 1 \\
\hline Average (AD) & $<500$ & 58,804 & 34,665 & 1,292 & 1,130 & 1,721 \\
\hline$\%$ RSD & --- & 0 & 0 & 6 & 1 & 2 \\
\hline \multicolumn{7}{|c|}{$100 \%$ Stoichiometry (42\% total solids target) } \\
\hline Average (PSAL) & 273 & 48,325 & 29,100 & 1,138 & 980 & 1,540 \\
\hline$\%$ RSD & 1 & 1 & 5 & 3 & 3 & 2 \\
\hline \multicolumn{7}{|c|}{$100 \%$ Stoichiometry with $\sim 3 X$ Antifoam Spike (45\% total solids target) } \\
\hline Average (PSAL) & 280 & 52,700 & 26,775 & 944 & 1,025 & 2,025 \\
\hline$\% \mathrm{RSD}$ & 1 & 1 & 2 & 2 & 1 & 1 \\
\hline \multicolumn{7}{|c|}{$100 \%$ Stoichiometry with $\sim 2 X$ Antifoam Spike (45\% total solids target) } \\
\hline Average (PSAL) & 291 & 55,233 & 31,033 & 854 & 944 & 1,838 \\
\hline$\%$ RSD & 2 & 3 & 3 & 3 & 4 & 6 \\
\hline Average (AD) & $<500$ & 61,760 & 36,239 & 1,313 & 1,152 & 1,787 \\
\hline$\%$ RSD & --- & 3 & 2 & 2 & 3 & 5 \\
\hline
\end{tabular}

Table 4-17. Average Measured Melter Feed TOC

\begin{tabular}{cc}
\hline \multicolumn{3}{c}{ TOC (ppm) } \\
\hline 125\% Stoichiometry (45\% total solids target) \\
\hline Average & 17,548 \\
\hline$\%$ RSD & 5 \\
\hline Average & 16,199 \\
\hline$\%$ RSD & 5 \\
\hline 100\% Stoichiometry (45\% total solids target) \\
\hline Average & 14,098 \\
\hline$\%$ RSD & 6 \\
\hline $100 \%$ Stoichiometry with $\sim 3 X$ Antifoam Spike & $(45 \%$ total solids target) \\
\hline Average & 16,935 \\
\hline$\% R S D$ & 2 \\
\hline $100 \%$ Stoichiometry with $\sim 2 X$ Antifoam Spike (45\% total solids target) \\
\hline Average & 17,336 \\
\hline$\% R S D$ & 6 \\
\hline
\end{tabular}




\subsubsection{Condensate Analysis}

The off-gas condensate and filtered solids collected during testing were analyzed to answer two fundamental questions: 1) how much glycolate is in the melter condensate and 2) are significant amounts of any other compounds in the melter condensate. Initial modelling of the melter off-gas indicated that $\sim 50 \%$ of the glycolate fed to the melter simply evaporated and would be condensed in the off-gas system. The melter testing performed at the Vitreous State Laboratory (VSL) to support the off-gas modelling did not have a condenser, therefore the model result could not be confirmed with experimental data. ${ }^{2}$

Testing indicates that very little glycolate is evaporated from the feed and that nearly all $(>99.5 \%)$ of the glycolate fed to the melter is destroyed. Glycolate concentrations in the melter off-gas condensate were typically in the 100 to $150 \mathrm{ppm}$ range as shown in Figure 4-34. Given that the initial fill of the condensate vessel was with process water, the upward trend during initial operation was expected. Peak glycolate concentrations were noted prior to the end of bubbled surge testing. Thus, the initial concentrations are lower than the steady state emissions while concentrations after the peak are higher than steady state emissions; however, the overall amount of glycolate noted in the condensate did not warrant more rigorous calculations. TOC in the melter off-gas condensate was very low and tracked closely with formate as shown in Figure 4-35. Organic carbon was always less than $300 \mathrm{ppm}$ and was typically less than $200 \mathrm{ppm}$. When compared to the TOC determined by calculating carbon from glycolate and formate (oxalate was not detected), the TOC measurement indicated from 50 to $150 \mathrm{ppm}$ of unaccounted for carbon. This difference could simply be the result of compilation of analytical errors or could indicate that presence of a small amount of a carbon species other than the anions listed. As with glycolate, the amount of TOC present did not warrant further investigation.

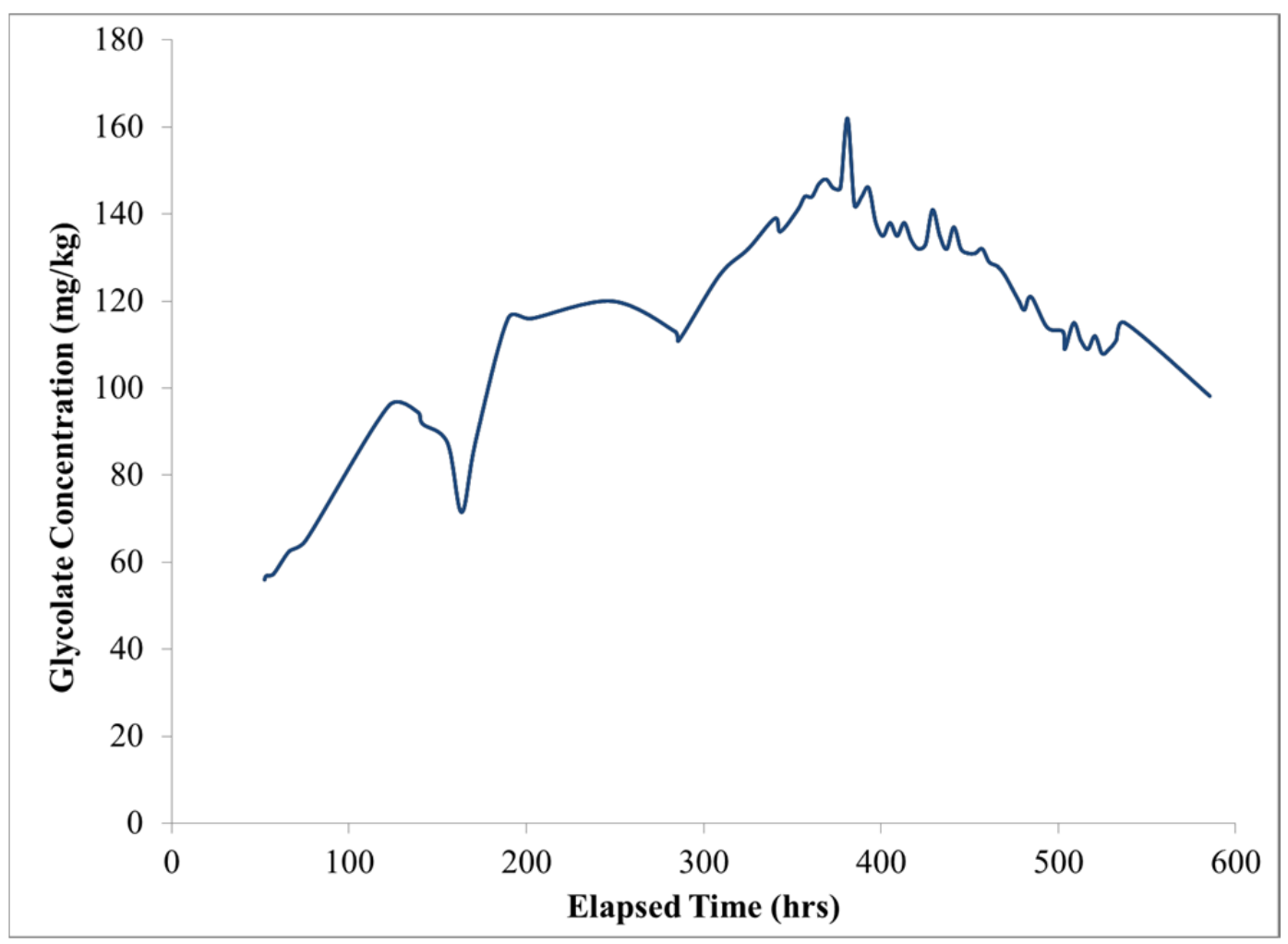

Figure 4-34. Glycolate concentration in the condensate throughout testing. 


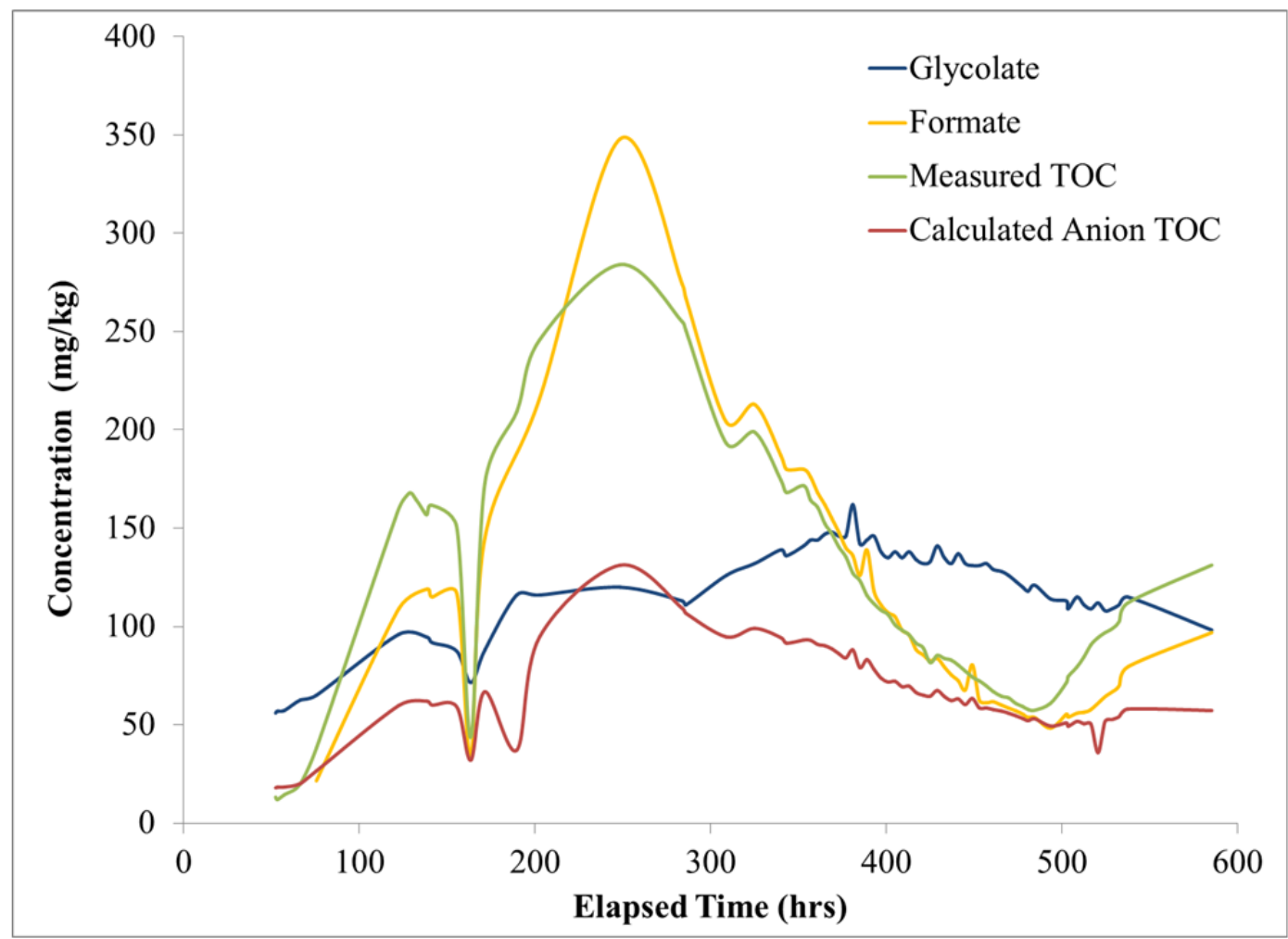

Figure 4-35. Glycolate, formate and TOC concentrations in the condensate.

The anion results indicate that nitrate was the predominant anion with concentrations more than 10 times higher than any other anion, as shown in Figure 4-36. As discussed for the glycolate concentration, the steady state emission rates are not well represented by the graph as the condensate tank started with a charge of process water. As in the case of glycolate, concentrations were not sufficiently high to warrant rigorous calculations. Nitrate in the off-gas indicates either decomposition of nitrate in the melter to $\mathrm{NO}_{\mathrm{x}}$, which is then absorbed into the off-gas condensate and converted to nitric acid, or entrainment of feed into the off-gas. Given that the other anions are much lower than would be explained by entrainment, the nitrate in the off-gas is primarily the result of nitrate decomposition in the melter; however, the $\mathrm{pH}$ of the condensate does not match the predicted $\mathrm{pH}$ of the condensate assuming the nitrate is present as nitric acid as shown in Figure 4-37. It is assumed that one of the solids species (such as frit) present in the condensate is buffering the $\mathrm{pH}$. 
SRNL-STI-2014-00157

Revision 0

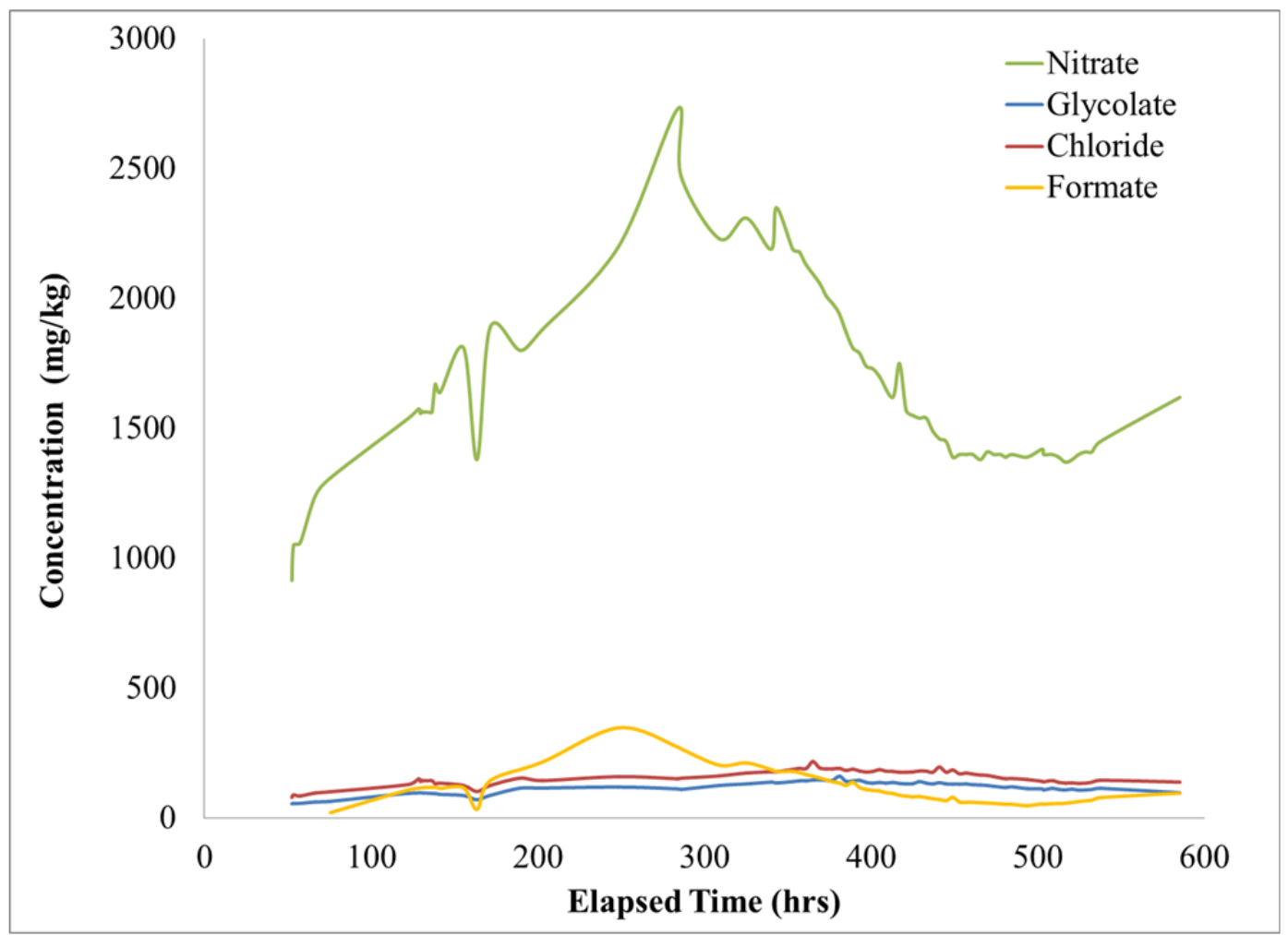

Figure 4-36. Comparison of anion concentrations in the condensate.

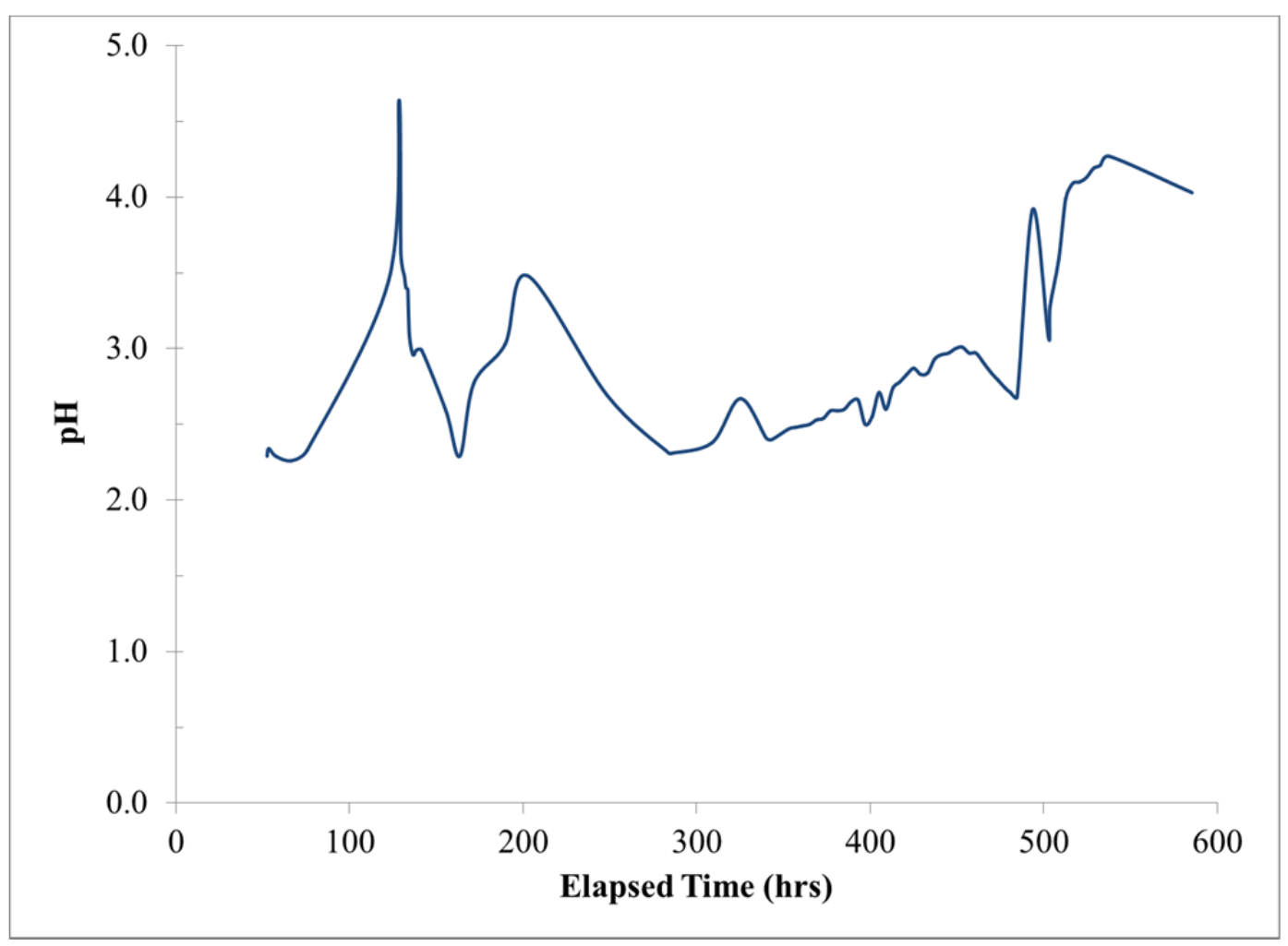

Figure 4-37. pH of the condensate throughout testing. 
Entrainment of solids during the CEF testing was typically around $0.05 \%$, but had a few peaks up to $0.3 \%$ of solids fed to the melter. Solids entrainment was measured by determining the amount of solids collected on the filters and dividing by the amount of solids fed to the melter. Figure 4-38 shows the entrainment during the run as well as when the bubblers were in operation. It should be noted that approximately 150 grams of solids were collected in the condensate compared with 830 grams collected on the filters. Therefore, the entrainment values determined are somewhat lower than actual, but are within $20 \%$ of the actual values based on the amounts collected elsewhere.

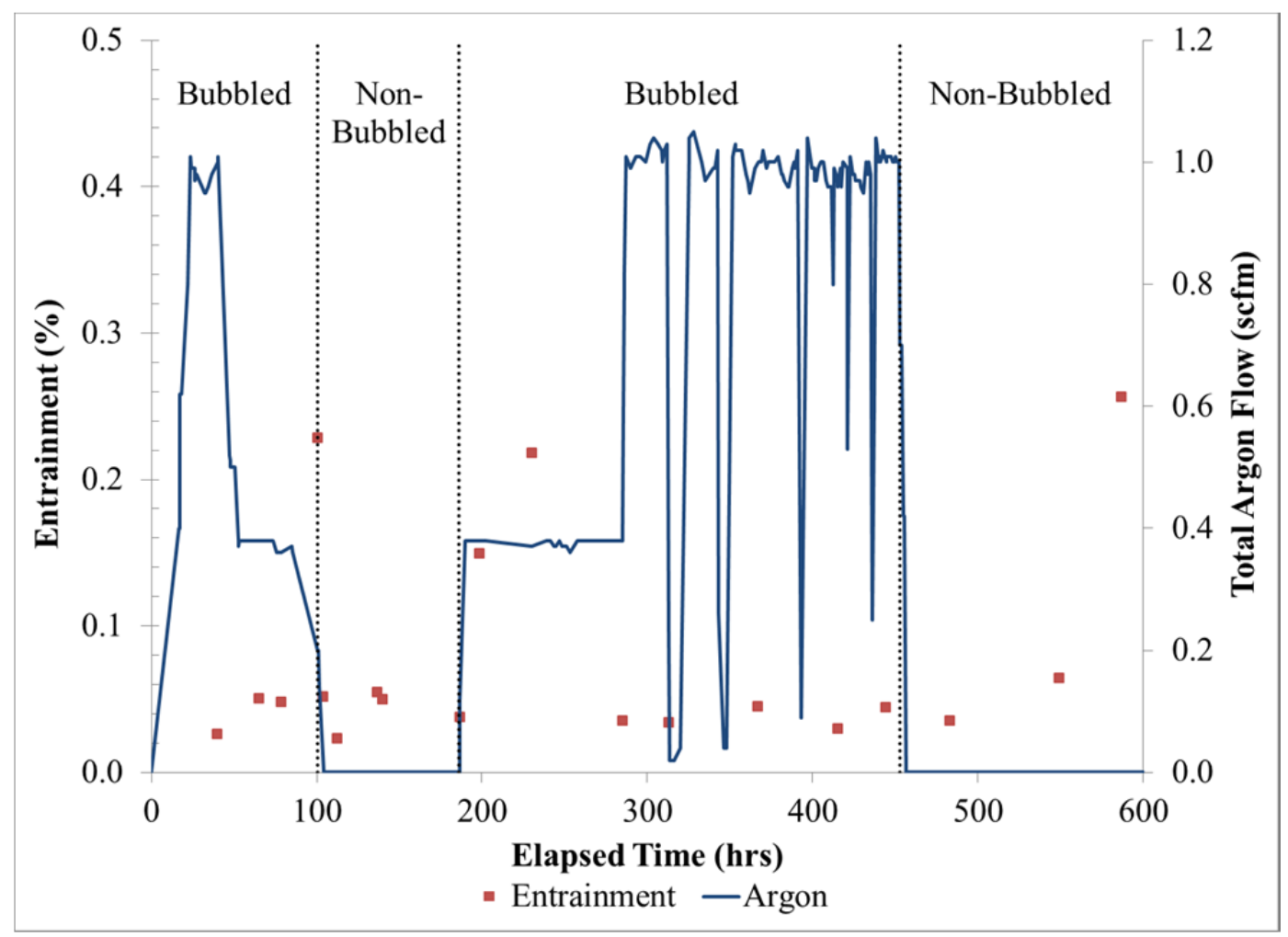

Figure 4-38. Comparison of entrainment and total argon flow throughout testing.

Cation results from the condensate samples were driven by solubility. Sodium was the dominant cation in the supernate, followed by aluminum, sulfur, boron ${ }^{\mathrm{ff}}$, manganese, and silicon as shown in Figure 4-39. Silicon was noted in higher concentrations during the spiked antifoam testing, as expected from degradation products of the antifoam.

Solids remaining in the condensate collection tank at the conclusion of the testing were deficient insoluble species as well as frit components as shown in Table 4-18. Soluble species were expected to be depleted since those solids would dissolve into the condensate versus collecting in the vessel. However, depletion of frit components was not expected as the frit solids should be larger than the feed solids. One possibility is that the frit carried into the off-gas was predominantly the fines from the frit addition versus being representative of the particle size of the bulk frit. The smaller frit particles would be easily suspended and would collect on the condensate filters versus collecting on the vessel bottom. Anion concentrations were very low compared to the amount of metals measured by ICP-AES, therefore it is presumed that the metals are predominately oxides.

\footnotetext{
${ }^{\mathrm{ff}}$ Boron was measured only for a small number of samples.
} 


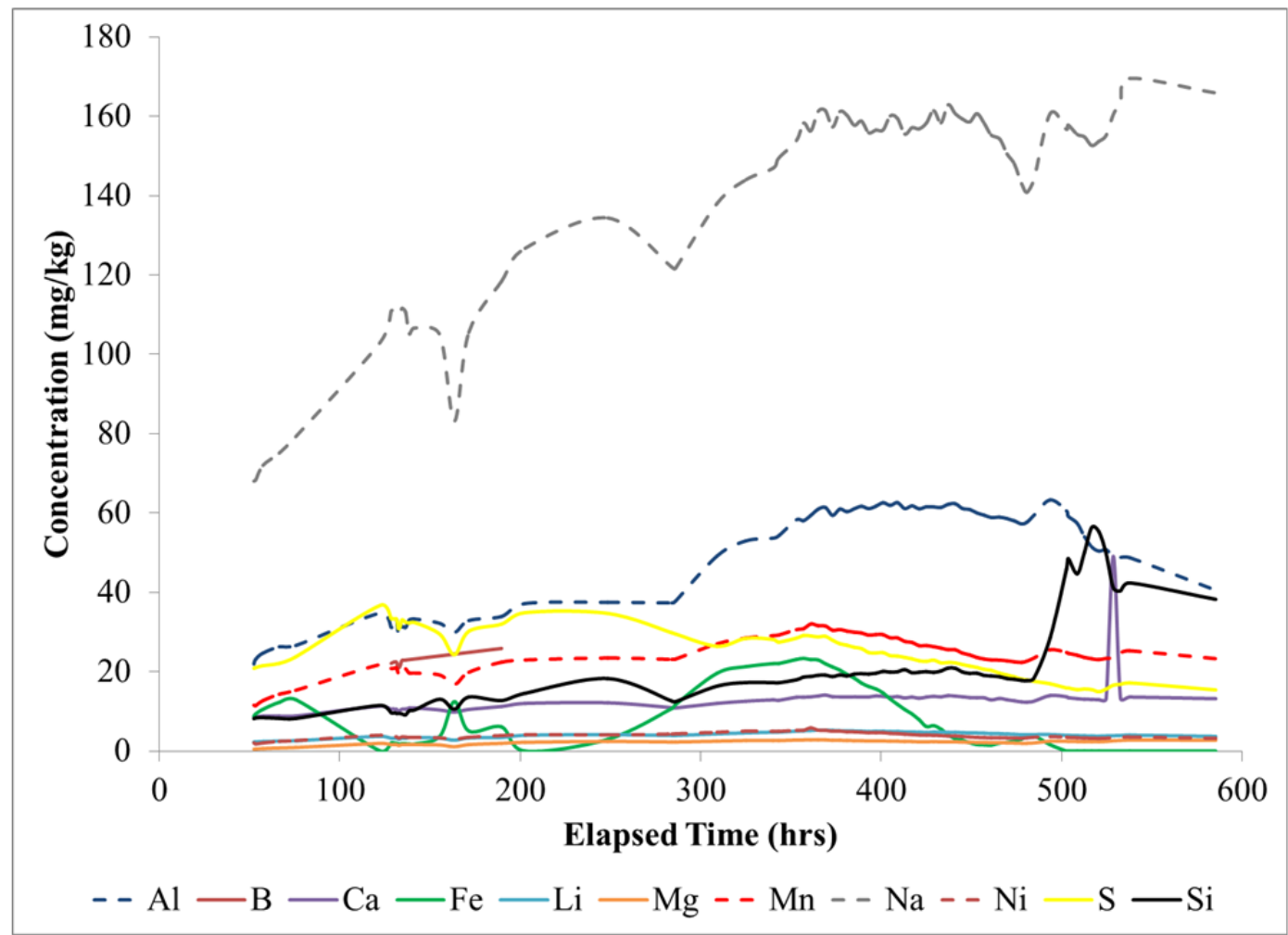

Figure 4-39. Metal concentrations in the condensate throughout testing.

Table 4-18. Composition of Condensate Tank Residual Solids (mg/kg)

\begin{tabular}{cccccc}
\hline Component & $\mathbf{A l}$ & $\mathbf{B a}$ & $\mathbf{C a}$ & $\mathbf{C r}$ & $\mathbf{C u}$ \\
\hline Average & 19700 & 186 & 699 & 124 & 414 \\
\hline Component & $\mathbf{F e}$ & $\mathbf{K}$ & $\mathbf{L i}$ & $\mathbf{M g}$ & $\mathbf{M n}$ \\
\hline Average & 101000 & 91 & 560 & 3185 & 21300 \\
\hline Component & $\mathbf{N a}$ & $\mathbf{N i}$ & $\mathbf{P}$ & $\mathbf{P b}$ & $\mathbf{S}$ \\
\hline Average & 2250 & 12050 & 497 & 102 & 2045 \\
\hline Component & $\mathbf{S i}$ & $\mathbf{S n}$ & $\mathbf{T i}$ & $\mathbf{Z n}$ & $\mathbf{Z r}$ \\
\hline Average & 850 & 55 & 160 & 514 & 15 \\
\hline Component & $\mathbf{F}$ & $\mathbf{C l}$ & $\mathbf{N O}$ & $\mathbf{N O}_{\mathbf{3}}$ & $\mathbf{C}_{\mathbf{2}} \mathbf{H}_{\mathbf{3}} \mathbf{O}_{\mathbf{3}}$ \\
\hline Average & $<100$ & 622 & 113 & 5245 & $<100$ \\
\hline Component & $\mathbf{S O}$ & $\mathbf{C}_{\mathbf{2}} \mathbf{O}_{\mathbf{4}}$ & $\mathbf{H C O}_{\mathbf{2}}$ & $\mathbf{P O}_{\mathbf{4}}$ & \\
\hline Average & 495 & $<100$ & 527 & $<100$ & \\
\hline
\end{tabular}

\subsubsection{Off-gas Filter Solids Analysis}

Metals in the off-gas filter solids are shown Figure 4-40. The species are generally present in proportion to their proportion in the melter feed or frit. Few notable trends were noted in the off-gas data, but one trend was identified in the type of solids entrained during the testing. During periods of bubbled 
operation, the iron and other sludge components were generally present in higher concentrations than frit components. During non-bubbled operation, the concentration of frit components in the condensate slightly increased as highlighted in Figure 4-41. The change in the curves around 300 hours is due to the large surge that occurred, which forced feeding to be stopped for more than 12 hours while the blower was replaced (see Section 4.4.3). During the low vapor space temperature testing, the frit components surpassed the sludge components in concentration. While an interesting observation, the overall amount of entrainment was so low that further evaluation was not considered. It is noted that the CEF vapor space height was increased versus the DWPF melter to reduce entrainment.

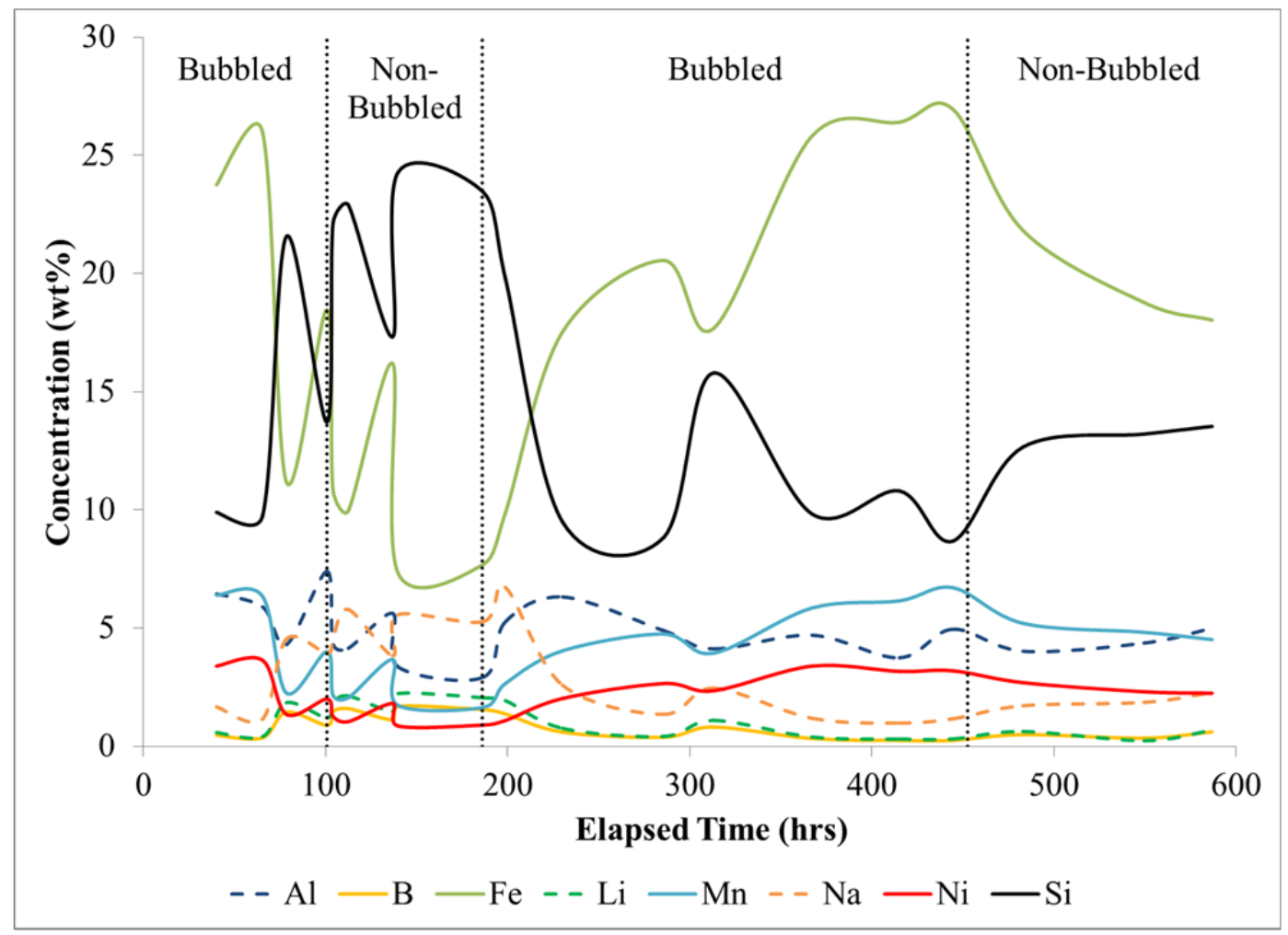

Figure 4-40. Metals composition in the off-gas filter solids as a function of time. 


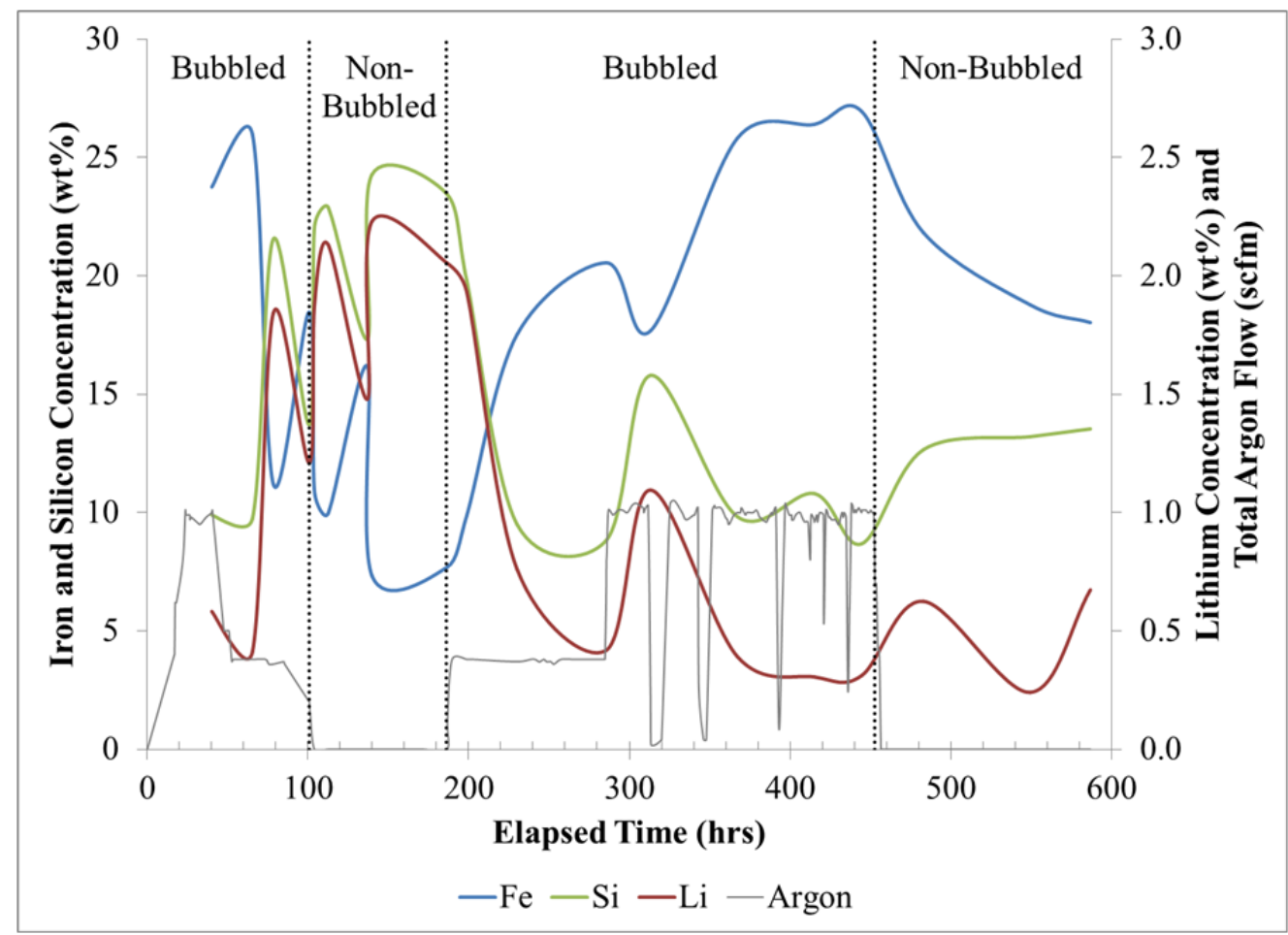

Figure 4-41. Comparison of $\mathrm{Fe}$, $\mathrm{Si}$ and $\mathrm{Li}$ concentrations in the off-gas filter solids. Note that the Li concentration is plotted on the secondary axis.

Iridescent flakes were observed in some, but not all, of the off-gas condensate system filter solids that were collected from the nineteen bag filters that were used throughout testing. ${ }^{\text {gg }}$ The flakes were observed during a variety of melter conditions; $125 \%$ and $100 \%$ stoichiometry melter feeds, both bubbled and non-bubbled. A comparison of the typical solids collected from these filters and the flake material is shown in Figure 4-42(a) and (b), respectively. Magnified views of the flakes are shown in Figure 4-43(a) and (b).

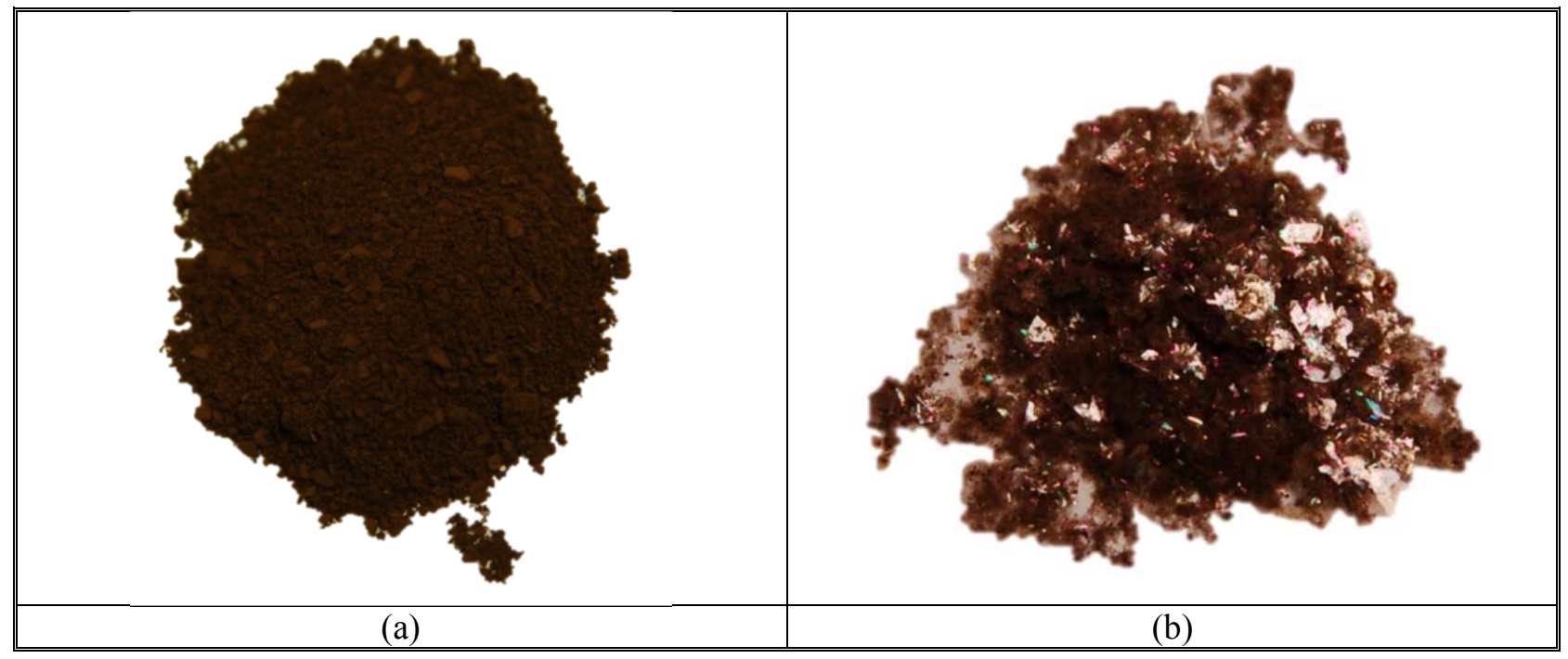

Figure 4-42. Image of typical filter solids (a) and filter solids containing flakes (b).

\footnotetext{
${ }^{\mathrm{gg}}$ Filters were observed with the naked eye only. The filter IDs are as follows: CEF2-FL-Q, -G, -D, -F, -H, -K and -L.
} 
The flakes are quite thin and are covered in small solid particles as shown in Figure 4-43(b) that are likely representative of the feed components. X-ray diffraction of both types of filter solids indicated that quartz $\left(\mathrm{SiO}_{2}\right)$ and magnetite $\left(\mathrm{Fe}^{+2} \mathrm{Fe}_{2}^{+3} \mathrm{O}_{4}\right)$ are present along with amorphous material, which is to be expected based on the composition of the SRAT product and frit. The amorphous hump is more pronounced in the filter solids containing flakes as shown in Figure 4-44; however, no conclusions can be drawn at this time based on these cursory scans. After a sample of flakes was heated to $500^{\circ} \mathrm{C}$, there was no indication that melting had occurred, so it does not appear to be a polymer or organic material. Based on the current analyses the flakes are amorphous and contain quartz and magnetite, but no further investigation of how and why this material formed has been pursued at present time.

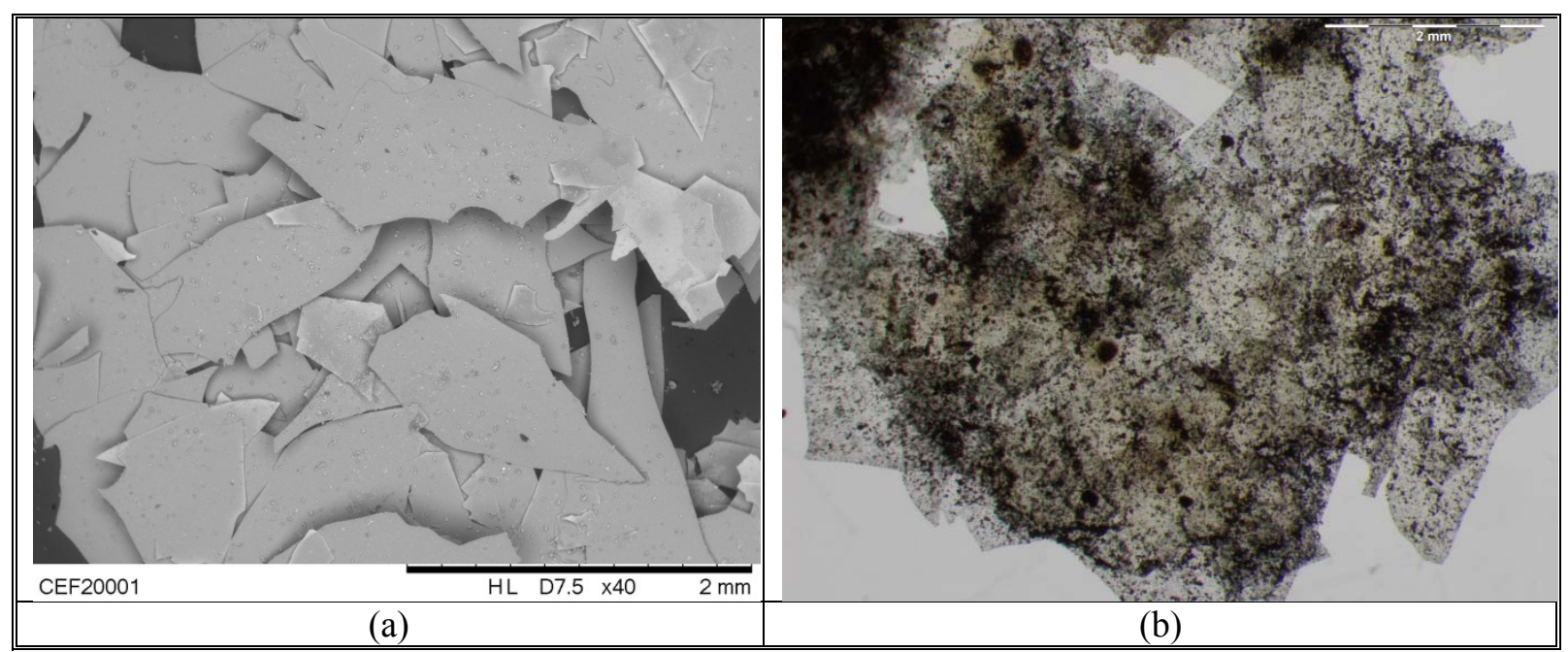

Figure 4-43. SEM image (a) and optical microscope image (b) of the iridescent flakes.

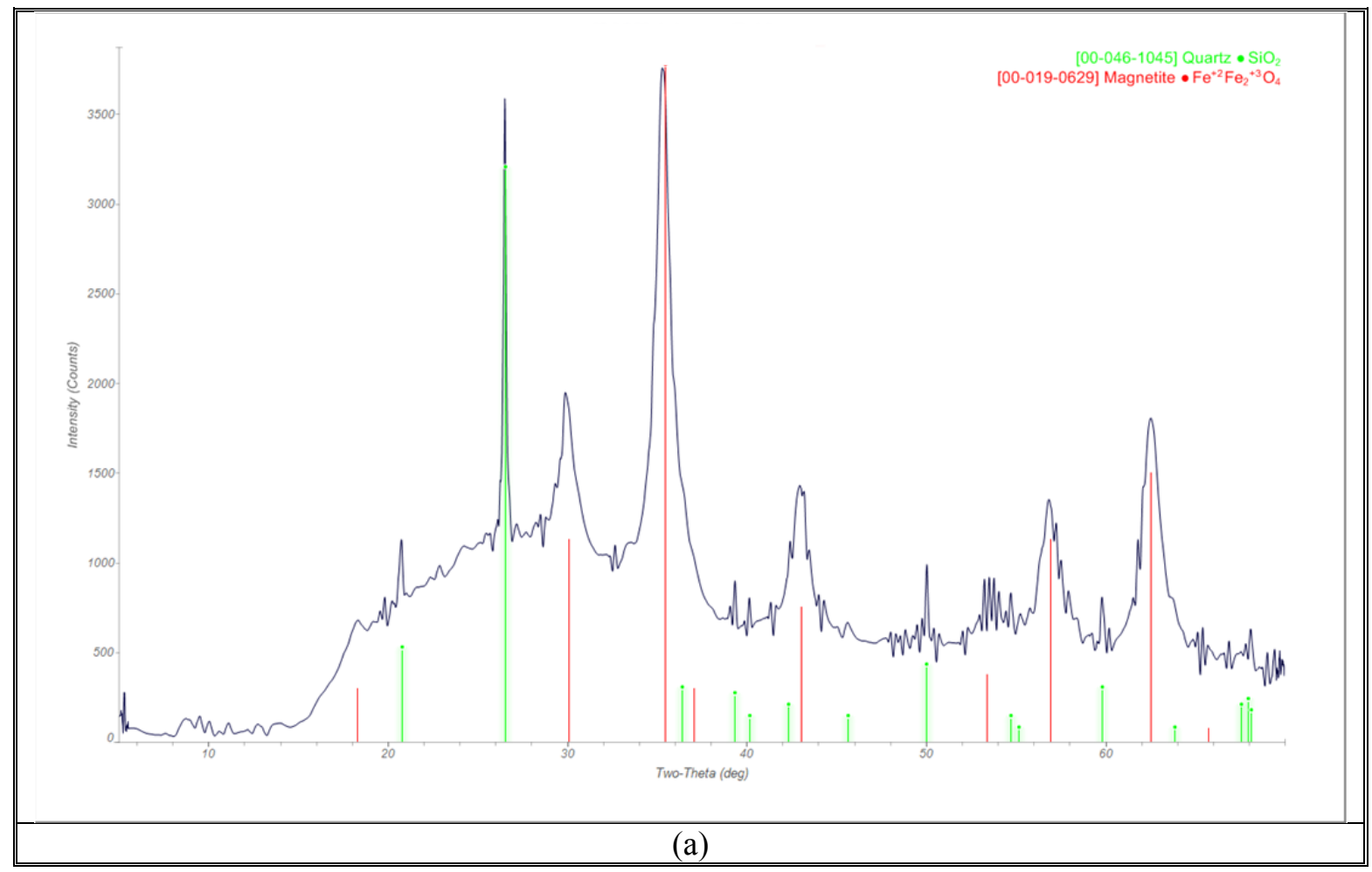




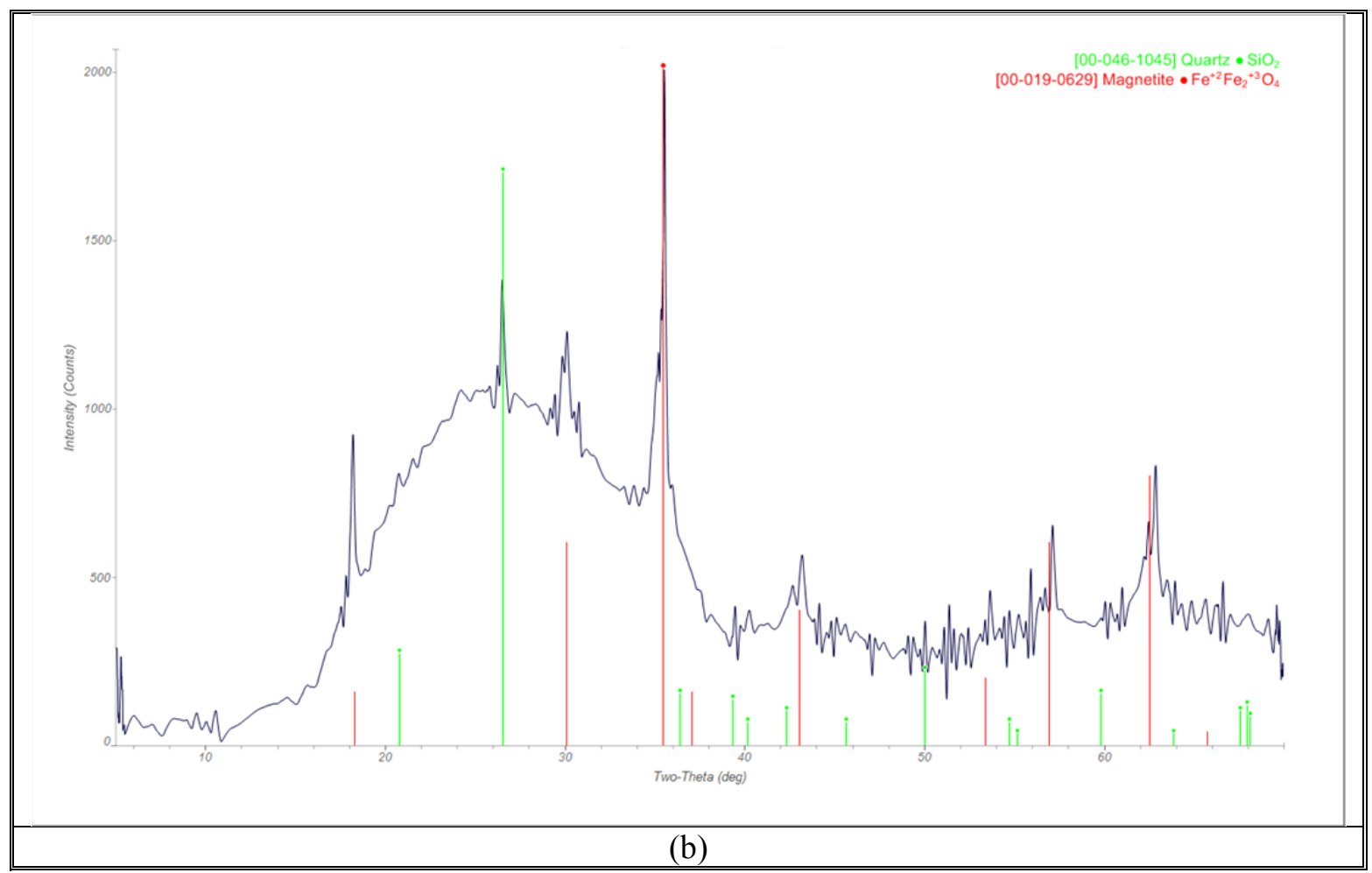

Figure 4-44. XRD spectra of typical filter solids (a) and filter solids containing flakes (b).

\subsubsection{Carbon Tube Analysis}

The gas chromatography-mass spectrometry (GCMS) analysis indicates that organics in the off-gas were present at very low quantities. ${ }^{59,60, \mathrm{hh}}$ Approximately $7.9 \mathrm{mg} / \mathrm{kg}$ of $\mathrm{C}_{8}-\mathrm{C}_{12}$ siloxanes (antifoam fragments) and $\sim 22 \mathrm{mg} / \mathrm{kg}$ of aliphatic hydrocarbons (impurities) were measured. The aliphatic hydrocarbons consisted primarily of butylcyclohexane, 6-dodecene, 1,5-diethyl-2,3-dimethylcyclohexane and hexylcyclohexane. While the siloxanes were present due to the antifoam, none of the hydrocarbon species would be expected to be in the melter feed or off-gas and could potentially be a contaminant from the vendor tanks. The siloxane content translates to $0.09 \mathrm{ppmv}$ in the off-gas per sample, or $0.63 \mathrm{ppmv}$ if all of the siloxanes were assumed to come from just one sample (worst case), which is still quite low. Thus, the amount of uncombusted organics in the off-gas is negligible.

Based on these results, one sample of the $100 \%$ stoichiometry melter feed was also submitted for SVOA and was extracted using dichloromethane (Table 4-19). This method is qualitative for many of the antifoam degradation polyethylene glycol (PEG) fragments. The main components in Antifoam 747 are not observed by this method. Starting with $\sim 2000 \mathrm{mg} / \mathrm{kg}$ of antifoam in the feed, approximately 24 $\mathrm{mg} / \mathrm{kg}$ of antifoam fragments were found by GCMS. The detected PEG species are compounds resulting from the degradation of the antifoam molecule (Table 4-20) and are best matches (not exact) to the NIST standard reference database. The presence of PEG ether cleavage products is expected. Under heated acidic conditions, cleavage of the ether linkages in the PEG molecule can occur resulting in shorter PEG molecules terminated in an alcohol functional group. The other fragments generated during degradation are trimethylsiloxy groups that are mostly evolved during the SRAT cycle to form HMDSO (hexamethyl disiloxane) in the off-gas. Some of the trimethylsiloxy groups are likely to polymerize to ring siloxanes $(5,6)$. Components 2-4 are ring species that would result from the PEG fragments. Species 7-9 are not

\footnotetext{
hh Twenty-four (24) carbon tube samples were taken during the CEF run. Seven of these were sent to AD for SVOA organics analysis. An error was made during analysis and all seven sample tubes were combined into one sample and analyzed.
} 
expected to be in the melter feed; these may have been present as impurities from the equipment used by the vendors that made the simulant and processed it into the SRAT product.

Table 4-19. Results of SVOA Analysis on Melter Feed

\begin{tabular}{|c|c|c|c|}
\hline & Component & $\begin{array}{l}\text { Amount } \\
(\mathrm{mg} / \mathrm{kg})\end{array}$ & Comments \\
\hline 1 & Cumulative PEG concentration (Table 4-20) & 21.6 & antifoam fragments \\
\hline 2 & Hexaethylene glycol dimethyl ether & 0.82 & antifoam fragment \\
\hline 3 & Cyclopentene, 1,2,3,4,5-pentamethyl- & 0.25 & antifoam fragment \\
\hline 4 & $2,5,8,11,14$-Pentaoxahexadecan-16-ol & 1.01 & antifoam fragment \\
\hline 5 & Cyclotetrasiloxane, octamethyl- & 0.13 & antifoam fragment \\
\hline \multirow[t]{2}{*}{6} & 1-Propene 3-[2-(2-methoxyethoxy)ethoxy]- & 0.11 & antifoam fragment \\
\hline & SUM OF ANTIFOAM FRAGMENTS & 24.32 & \\
\hline 7 & 12 -Bis(trimethylsilyl)benzene & 0.33 & potentially from column bleed \\
\hline 8 & Formamide N N-dioctyl- & 0.18 & unexpected \\
\hline \multirow[t]{2}{*}{9} & 12 -Monooctyl phthalic acid ester & 0.14 & $\begin{array}{l}\text { potentially from plasticizer } \\
\text { (sample bottles) }\end{array}$ \\
\hline & SUM OF UNEXPECTED SPECIES & 0.65 & \\
\hline
\end{tabular}

Table 4-20. PEG Species in Melter Feed

\begin{tabular}{cc}
\hline PEG Species & $\begin{array}{c}\text { Amount } \\
\text { (mg/kg) }\end{array}$ \\
\hline $\mathrm{CH}_{3} \mathrm{O}-\left(\mathrm{CH}_{2} \mathrm{CH}_{2} \mathrm{O}\right)_{7}-\mathrm{CH}_{2} \mathrm{CH}_{2} \mathrm{OOCCH}$ & 10.4 \\
\hline $\mathrm{CH}_{3} \mathrm{O}-\left(\mathrm{CH}_{2} \mathrm{CH}_{2} \mathrm{O}\right)_{6}-\mathrm{CH}_{2} \mathrm{CH}_{2} \mathrm{OOCCH} \mathrm{H}_{3}$ & 3.42 \\
\hline $\mathrm{CH}_{3} \mathrm{O}-\left(\mathrm{CH}_{2} \mathrm{CH}_{2} \mathrm{O}\right)_{6}-\mathrm{CH}_{2} \mathrm{CH}_{2} \mathrm{OH}$ & 0.13 \\
\hline $\mathrm{CH}_{3} \mathrm{O}-\left(\mathrm{CH}_{2} \mathrm{CH}_{2} \mathrm{O}\right)_{8}-\mathrm{CH}_{2} \mathrm{CH}_{2} \mathrm{OH}$ & 0.21 \\
\hline $\mathrm{CH}_{3} \mathrm{O}-\left(\mathrm{CH}_{2} \mathrm{CH}_{2} \mathrm{O}\right)_{9}-\mathrm{CH}_{2} \mathrm{CH}_{2} \mathrm{OH}$ & 0.18 \\
\hline $\mathrm{HO}-\left(\mathrm{CH}_{2} \mathrm{CH}_{2} \mathrm{O}\right)_{6}-\mathrm{CH}_{2} \mathrm{CH}_{2} \mathrm{OH}$ & 3.90 \\
\hline $\mathrm{HO}-\left(\mathrm{CH}_{2} \mathrm{CH}_{2} \mathrm{O}\right)_{11}-\mathrm{CH}_{2} \mathrm{CH}_{2} \mathrm{OH}$ & 2.15 \\
\hline $\mathrm{CH}_{3} \mathrm{O}-\left(\mathrm{CH}_{2} \mathrm{CH}_{2} \mathrm{O}\right)_{4}-\mathrm{Si}\left(\mathrm{CH}_{3}\right)_{2} \mathrm{C}\left(\mathrm{CH}_{3}\right)_{3}$ & 0.30 \\
\hline $\mathrm{CH}_{3} \mathrm{O}-\left(\mathrm{CH}_{2} \mathrm{CH}_{2} \mathrm{O}\right)_{5}-\mathrm{Si}\left(\mathrm{CH}_{3}\right)_{2} \mathrm{C}\left(\mathrm{CH}_{3}\right)_{3}$ & 0.30 \\
\hline $\mathrm{CH}_{3} \mathrm{O}-\left(\mathrm{CH}_{2} \mathrm{CH}_{2} \mathrm{O}\right)_{9}-\mathrm{Si}\left(\mathrm{CH}_{3}\right)_{2} \mathrm{C}\left(\mathrm{CH}_{3}\right)_{3}$ & 0.13 \\
\hline $\mathrm{CH}_{3} \mathrm{O}-\left(\mathrm{CH}_{2} \mathrm{CH}_{2} \mathrm{O}\right)_{10}-\mathrm{Si}\left(\mathrm{CH}_{3}\right)_{2} \mathrm{C}\left(\mathrm{CH}_{3}\right)_{3}$ & 0.27 \\
\hline $\mathrm{CH} \mathrm{O}_{3}-\left(\mathrm{CH}_{2} \mathrm{CH} \mathrm{CH}_{2} \mathrm{O}\right)_{11}-\mathrm{Si}\left(\mathrm{CH}_{3}\right)_{3}$ & 0.22 \\
\hline
\end{tabular}

\subsubsection{Glass Analysis}

The average measured glass composition is shown in Table 4-21. ${ }^{\mathrm{ii}}$ The $\% \mathrm{RSD}$ values for the major glass components $(>0.5 \mathrm{wt} \%)$ are less than 5\%, which confirms consistent melter feed batching. A comparison of the calculated glass composition, average measured melter feed composition and average measured glass composition are shown in Table 4-22. The calculated glass composition was determined by combining the average measured SB6I $100 \%$ and $125 \%$ as-received SRAT composition with the target Frit 418 composition at a waste loading of $36 \%$. No significant deviations are present between the

\footnotetext{
${ }^{\text {ii }}$ Seventeen (17) pour stream glasses collected over the duration of testing were selected for analysis.
} 
calculated and measured compositions, which indicate that the melter feed was batched according to the targets specified on the batch sheets from an elemental perspective.

Table 4-21. Average Glass Composition (wt\%)

\begin{tabular}{ccc}
\hline Oxide & Average & \%RSD \\
\hline $\mathrm{Al}_{2} \mathrm{O}_{3}$ & 9.21 & 1.8 \\
\hline $\mathrm{B}_{2} \mathrm{O}_{3}$ & 4.86 & 2.6 \\
\hline $\mathrm{BaO}$ & 0.06 & 1.7 \\
\hline $\mathrm{CaO}$ & 0.59 & 4.5 \\
\hline $\mathrm{Cr}_{2} \mathrm{O}_{3}$ & 0.11 & 8.7 \\
\hline $\mathrm{CuO}$ & 0.11 & 51.3 \\
\hline $\mathrm{Fe}_{2} \mathrm{O}_{3}$ & 10.8 & 1.3 \\
\hline $\mathrm{K}_{2} \mathrm{O}$ & 0.14 & 2.7 \\
\hline $\mathrm{Li}_{2} \mathrm{O}$ & 4.95 & 1.4 \\
\hline $\mathrm{MgO}$ & 0.58 & 1.2 \\
\hline
\end{tabular}

\begin{tabular}{ccc}
\hline Oxide & Average & \%RSD \\
\hline $\mathrm{MnO}$ & 3.19 & 1.3 \\
\hline $\mathrm{Na}_{2} \mathrm{O}$ & 11.6 & 1.3 \\
\hline $\mathrm{NiO}$ & 1.35 & 4.8 \\
\hline $\mathrm{P}_{2} \mathrm{O}_{5}$ & $<0.23$ & --- \\
\hline $\mathrm{SO}_{4}$ & 0.40 & 3.1 \\
\hline $\mathrm{SiO}_{2}$ & 49.7 & 1.2 \\
\hline $\mathrm{SnO}_{2}$ & $<0.13$ & --- \\
\hline $\mathrm{TiO}_{2}$ & 0.04 & 1.0 \\
\hline $\mathrm{ZnO}_{2 n}$ & 0.05 & 1.5 \\
\hline $\mathrm{ZrO}_{2}$ & 0.14 & 2.2 \\
\hline
\end{tabular}

Table 4-22. Comparison of Calculated and Measured Compositions (wt\%)

\begin{tabular}{cccc}
\hline Component & $\begin{array}{c}\text { Calculated Glass } \\
\text { Composition }\end{array}$ & $\begin{array}{c}\text { Average Measured } \\
\text { Melter Feed Composition }\end{array}$ & $\begin{array}{c}\text { Average Measured Glass } \\
\text { Composition }\end{array}$ \\
\hline $\mathrm{Al}_{2} \mathrm{O}_{3}$ & 9.49 & 9.98 & 9.21 \\
\hline $\mathrm{B}_{2} \mathrm{O}_{3}$ & 5.12 & 4.90 & 4.86 \\
\hline $\mathrm{CaO}$ & 0.59 & 0.58 & 0.59 \\
\hline $\mathrm{Fe}_{2} \mathrm{O}_{3}$ & 11.0 & 11.5 & 10.8 \\
\hline $\mathrm{Li}_{2} \mathrm{O}$ & 5.12 & 4.85 & 4.95 \\
\hline $\mathrm{MgO}_{\mathrm{MnO}}$ & 0.50 & 0.54 & 0.58 \\
\hline $\mathrm{Na}_{2} \mathrm{O}$ & 3.17 & 3.22 & 3.19 \\
\hline $\mathrm{NiO}_{\mathrm{SiO}}$ & 11.6 & 12.1 & 11.6 \\
\hline & 1.34 & 1.34 & 1.35 \\
\hline
\end{tabular}

$\mathrm{Fe}^{2+} / \sum \mathrm{Fe}$ ratios for select glass samples are shown in Table 4-23. Initial $\mathrm{Fe}^{2+} / \sum \mathrm{Fe}$ values were approximately 0.05 and generally decreased with time. The first measured sample (CEF2-GL-001) was collected after feeding with $125 \%$ stoichiometry melter feed for approximately 1.5 days under bubbled conditions. By the seventh day of testing (March 2, 2014), the pour stream glass was fully oxidized as shown by sample CEF2-GL-026 and samples remained fully oxidized for the remainder of testing. For comparison, the $\mathrm{Fe}^{2+} / \sum \mathrm{Fe}$ values for the Phase I nitric-formic acid flowsheet CEF testing were in the range of 0.08-0.20. ${ }^{52}$ Laboratory studies and actual DWPF pour stream and melter feed samples have shown that both argon bubbling and excess antifoam increase the $\mathrm{Fe}^{2+} / \sum \mathrm{Fe}$ ratio, thus it would have been expected that a majority, if not all of the CEF pour stream glasses, should not have been so oxidized. ${ }^{61,62}$ 
Table 4-23. Glass REDOX

\begin{tabular}{ccccc}
\hline Sample ID & Date & Time & $\mathbf{F e}^{2+} / \mathbf{F e}^{3+}$ & $\mathbf{F e}^{2+} / \sum \mathbf{F e}$ \\
\hline CEF2-GL-001 & $2 / 26 / 2014$ & $8: 55$ & 0.06 & 0.05 \\
\hline CEF2-GL-003 & $2 / 26 / 2014$ & $19: 05$ & 0.05 & 0.05 \\
\hline CEF2-GL-004 & $2 / 26 / 2014$ & $23: 00$ & 0.04 & 0.04 \\
\hline CEF2-GL-006 & $2 / 27 / 2014$ & $7: 00$ & 0.04 & 0.04 \\
\hline CEF2-GL-008 & $2 / 27 / 2014$ & $15: 00$ & 0.03 & 0.03 \\
\hline CEF2-GL-010 & $2 / 27 / 2014$ & $23: 50$ & 0.04 & 0.04 \\
\hline CEF2-GL-012 & $2 / 28 / 2014$ & $8: 12$ & 0.04 & 0.03 \\
\hline CEF2-GL-013 & $2 / 28 / 2014$ & $15: 32$ & 0.02 & 0.02 \\
\hline CEF2-GL-014 & $2 / 28 / 2014$ & $21: 25$ & 0.02 & 0.02 \\
\hline CEF2-GL-016 & $3 / 1 / 2014$ & $5: 25$ & 0.02 & 0.02 \\
\hline CEF2-GL-018 & $3 / 1 / 2014$ & $13: 47$ & 0.02 & 0.02 \\
\hline CEF2-GL-020 & $3 / 1 / 2014$ & $21: 30$ & 0.03 & 0.02 \\
\hline CEF2-GL-022 & $3 / 2 / 2014$ & $6: 32$ & 0.02 & 0.02 \\
\hline CEF2-GL-024 & $3 / 2 / 2014$ & $14: 20$ & 0.02 & 0.02 \\
\hline CEF2-GL-026 & $3 / 2 / 2014$ & $22: 40$ & $\mathrm{All} \mathrm{Fe}$ & $\mathrm{All} \mathrm{Fe}$ \\
\hline
\end{tabular}

In order to further determine the source of these results, sealed crucible samples were made post-run with each of the three types of remediated melter feeds that were prepared during actual CEF testing (100\% stoichiometry, $125 \%$ stoichiometry and $\sim 2 \mathrm{X}$ antifoam spike). For comparison, two additional glass samples were prepared from the $100 \%$ stoichiometry and $\sim 2 \mathrm{X}$ antifoam spike melter feeds using an open top quartz crucible with flowing argon. ${ }^{51}$ The $\mathrm{Fe}^{2+} / \sum \mathrm{Fe}$ data from these tests are shown in Table 4-24. As expected, the post-test $\mathrm{Fe}^{2+} / \sum \mathrm{Fe}$ values of 0.44 and 0.57 for the melter feed spiked with additional antifoam are considerably higher than the baseline values of 0.25 and 0.27 for the $100 \%$ feed. Even though antifoam spiked feed was added to the melter for $\sim 2.2$ days, the pour stream glass was still oxidized. Of these $\sim 2.2$ days, the first $\sim 16$ hours were dedicated to melter feed that was spiked with three times the nominal amount of antifoam. While not measured, it is expected that the $\mathrm{Fe}^{2+} / \sum \mathrm{Fe}$ value of this glass would exceed the 0.42 value that was measured for the $\sim 2 \mathrm{X}$ antifoam spiked feed.

Table 4-24. Comparison of $\mathrm{Fe}^{2+} / \sum \mathrm{Fe}$ Values

\begin{tabular}{|c|c|c|c|}
\hline $\begin{array}{c}\text { Pre Test Remediated } \\
\text { Melter Feed } \\
\text { (sealed crucible) }\end{array}$ & $\begin{array}{c}\text { Post Test Remediated } \\
\text { Melter Feed } \\
\text { (s ealed crucible) } \\
\end{array}$ & $\begin{array}{c}\text { Post Test Remediated } \\
\text { Melter Feed } \\
\text { (open quartz crucible) }\end{array}$ & $\begin{array}{c}\text { CEF Pour } \\
\text { Stream Glas s }\end{array}$ \\
\hline \multicolumn{4}{|c|}{ 125\% Stiochiometry } \\
\hline $0.10-0.48^{*}$ & 0.27 & --- & $0.02-0.05$ \\
\hline \multicolumn{4}{|c|}{ 100\% Stoichiometry } \\
\hline 0.25 & 0.25 & 0.27 & fully oxidized \\
\hline \multicolumn{4}{|c|}{$100 \%$ Stoichiometry with $\sim 2 X$ Antifoam Spike } \\
\hline--- & 0.44 & 0.57 & fully oxidized \\
\hline
\end{tabular}

*As stated in Section 3.2, a blend of the "low" and "medium" glycolic acid concentrations was selected for the $125 \%$ melter feed and there is not a pre-test measured REDOX measurement for the blend.

The configuration of the melter was not changed between Phase I and Phase II testing. Preliminary unreviewed air in-leakage calculations in support of the flammability model development indicate that air 
in-leakage was comparable to Phase I testing. While higher air purge rates were used during portions of Phase II testing, which would have created conditions for more oxidized glass, the REDOX should have also been oppositely impacted by the argon bubblers and especially the excess antifoam additions. Thus, some of the samples should have exhibited $\mathrm{Fe}^{2+} / \sum \mathrm{Fe}$ values greater than 0 based solely on the testing environment and additions of antifoam. Based on the inconclusive data, the cause for the differences in REDOX is still under investigation.

\subsection{Off-gas Analysis}

Continuous monitoring of the off-gas stream was conducted using the mass spectrometer, gas chromatograph and FTIR. The primary components of interest were $\mathrm{H}_{2}, \mathrm{CO}, \mathrm{CO}_{2}$ and to a lesser extent $\mathrm{NO}$ and $\mathrm{NO}_{2}$. Only an overview of the off-gas analysis is presented in this report. A discussion of the off-gas analysis and relationship of this data to the flammability model development is provided in a separate report. ${ }^{11}$ Hydrogen generation during bubbled and non-bubbled surge testing conditions was an area of particular interest as shown in Figure 4-45 for the 100\% stoichiometry feed at $42 \mathrm{wt} \%$ total solids. Increases in hydrogen concentration were most prevalent during bubbled testing with the highest peaks at $\sim 700 \mathrm{ppm}$. During non-bubbled conditions, the hydrogen concentration remained less than $100 \mathrm{ppm}$. All data for $\mathrm{H}_{2}$ and $\mathrm{CO}$ are shown in Appendix Figure A-51 through Figure A-60. It should be noted that increased air purges were used during certain segments of the steady state vapor space temperature testing, which resulted in more dilution of the off-gas stream.

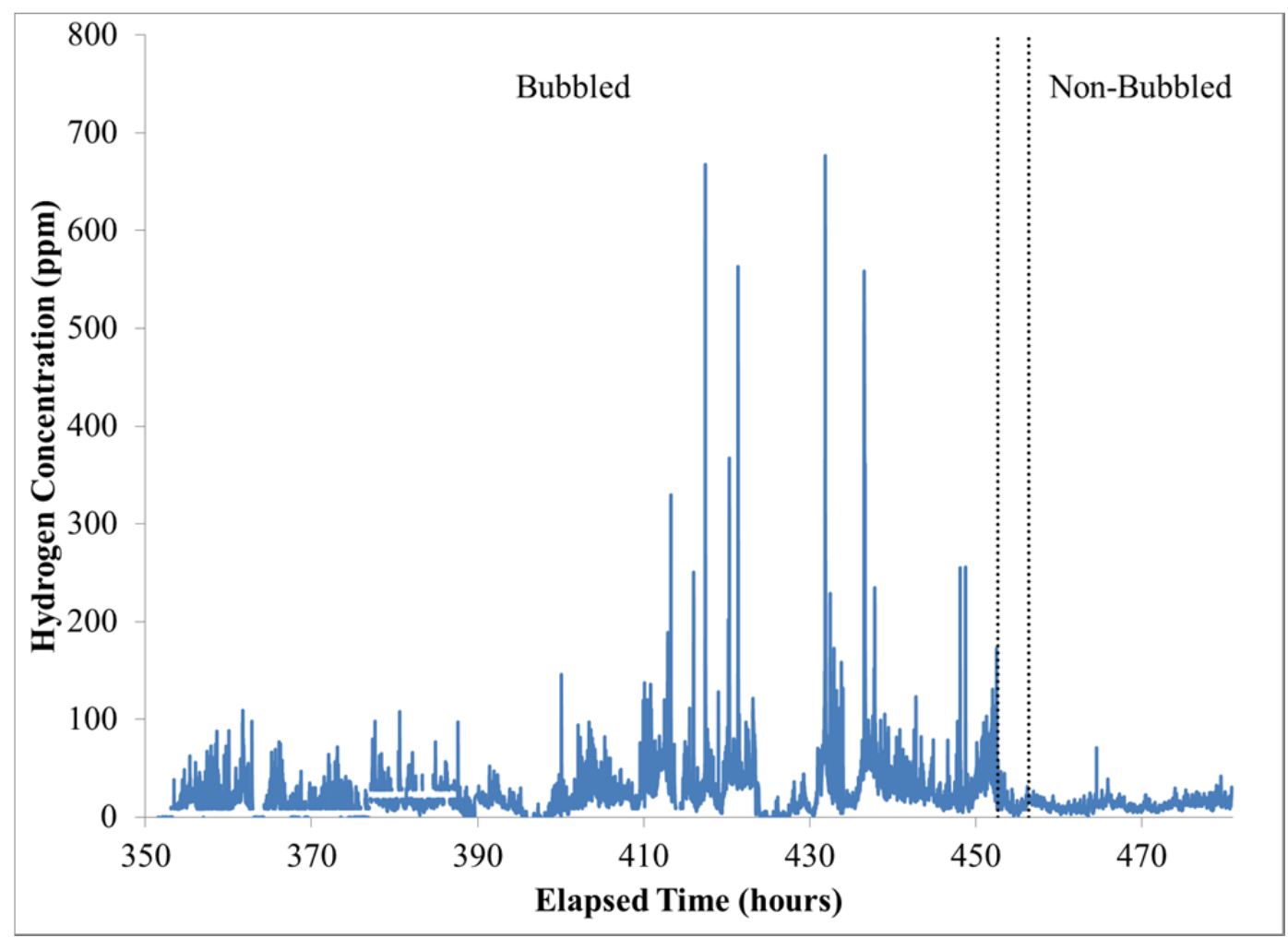

Figure 4-45. Hydrogen generation during bubbled and non-bubbled surge testing.

\subsection{Conclusions}

After charging the CEF with cullet from Phase I CEF testing, the melter was slurry-fed with glycolic flowsheet based SB6-Frit 418 melter feed at 36\% waste loading and was operated continuously for 25 days. Process data was collected throughout testing and included melter operation parameters and off-gas chemistry. In order to support the flammability model development for the nitric-glycolic flowsheet, 
vapor space steady state testing in the range of $\sim 250-750^{\circ} \mathrm{C}$ was conducted under the following conditions, (i) $100 \%$ (nominal and excess antifoam levels) and 125\% stoichiometry feed and (ii) with and without argon bubbling. Adjustments to feed rate, heater outputs and purge air flow were necessary in order to achieve vapor space temperatures in this range. Surge testing was also completed under nominal conditions for 4 days with argon bubbling and 1 day without argon bubbling in order to assess the surge potential for the new flowsheet.

The results of the Phase II testing demonstrated that the current configuration of the CEF is capable of operating under the low vapor space temperatures. A melter pressure of -5 inwc was not sustained throughout the run, but the melter did remain slightly negative even when the maximum air flow required for the lowest temperature conditions were used. By limiting the output on the auxiliary pour tube heater to 175 watts, the heater lasted the duration of testing even though the conditions in the CEF are highly atypical for this type of heater. As in the Phase I campaign, the J.M. Canty, Inc. high temperature camera provided exceptional views of the cold cap throughout testing.

Obvious differences in the consistency of the melter feeds of different acid stoichiometries were observed; $100 \%$ was quite thin, while the $125 \%$ was considerably thicker. Intuitively, the $125 \%$ stoichiometry feed should have been thinner as compared to the $100 \%$ feed due to increased acid. The addition of excess antifoam caused foaming in the mixing pot, but there was no evidence of foaming in the melter. Generally, the appearance of the cold cap during nitric-glycolic testing was no different than that of the nitric-formic flowsheet, which was observed during Phase I testing during non-bubbled steady state testing. At vapor space temperatures above $500^{\circ} \mathrm{C}$, a glass production rate in the range of 27-30 $\mathrm{g} / \mathrm{min}$ was achieved for the nitric-formic flowsheet and 31-44 $\mathrm{g} / \mathrm{min}$ was attained for the nitric-glycolic flowsheet during non-bubbled conditions.

Testing indicates that very little glycolate is evaporated from the feed and that nearly all $(>99.5 \%)$ of the glycolate fed to the melter is destroyed. TOC in the melter off-gas condensate was very low and tracked closely with formate. The condensate anion results indicate that nitrate was the predominant anion with concentrations approximately 10 times higher than any other anion. Entrainment of solids during the CEF testing was typically around $0.05 \%$, but had a few peaks up to $0.3 \%$ of solids fed to the melter. Cation results from the condensate samples were driven by solubility. Sodium was the dominant cation in the supernate, followed by aluminum, sulfur, boron, manganese, and silicon. Solids remaining in the condensate collection tank at the conclusion of the testing were deficient in soluble species as well as frit components. Depletion of frit components was not expected as the frit solids should be larger than the feed solids. One possibility is that the frit carried into the off-gas was predominantly the fines from the frit addition versus being representative of the particle size of the bulk frit Anion concentrations were very low compared to the amount of metals present, therefore it is presumed that the metals are predominately oxides. Metals in the off-gas filter solids were generally present in proportion to their proportion in the melter feed, with the exception of frit components, which were present in much lower concentrations than in the melter feed.

Generally, the REDOX of the glasses collected from the pour stream were fully oxidized (all $\mathrm{Fe}^{3+}$ ), which was not expected based on anticipated values for the melter feeds. Sealed crucible studies of the various melter feeds resulted in $\mathrm{Fe}^{2+} / \sum \mathrm{Fe}$ values in the range of 0.25-0.42. Laboratory studies and actual DWPF pour stream and melter feed samples have shown that both argon bubbling and excess antifoam increase the $\mathrm{Fe}^{2+} / \sum \mathrm{Fe}$ ratio; however, no impact was observed during this testing.

The total operational hours on the melter vessel is approximately 1057 hours after Phase II testing. Dimensional measurements taken prior to Phase I testing and support block temperatures recorded during Phase I/Phase II testing are available if an extension of service life beyond 1250 hours is desired in the future. 


\subsection{Recommendations, Path Forward or Future Work}

Based on the results from this testing, the following items are recommended for future study in support of the implementation of the nitric-glycolic flowsheet.

- Further REDOX testing and data interpretation are necessary in order to more thoroughly understand the effect of the nitric-glycolic flowsheet on glass REDOX during melter runs, as well as the impact of the testing protocol.

- Further testing to determine the impact of acid stoichiometry on the rheological properties of SME product. Increasing yield stress as acid stoichiometry increases has been noted during CPC testing, thus a better understanding of when increased acid stoichiometry begins to result in higher yield stress is needed.

- Further analysis of the flakes that were present in some of the solids collected from the off-gas condensate system filters. Determine if there are any negative impacts to processing.

- Further analysis of the lard-like material found in some of the drums of SRAT product. Determine if there are any negative impacts to processing.

- Conduct melt rate testing using the melt rate furnace (MRF) and potentially the slurry fed melt rate furnace (SMRF) with melter feeds fabricated with leftover CEF SRAT products to compare the nitric-formic and nitric-glycolic flowsheets. These samples should then be submitted for analysis by X-ray computed tomography (CT) so that more quantitative comparisons can be made. Melt rate testing under bubbled conditions would also be of interest. The CEF could also be operated under nominal conditions to generate bubbled melt rate data under nominal conditions if feed is available.

The following items are recommended prior to any future testing with the current CEF melter vessel.

- Perform dimensional measurements of the vessel and tension rod length measurements.

- Conduct a melter life assessment using the thermocouple data from Phase I and II testing and the post-test measurements to determine if the service life could be safely extended beyond 1250 hours.

- Add an argon purge to the pour tube in order to reduce the oxidizing effect of air contacting the molten glass pour stream and minimize REDOX uncertainty.

- Replace all heaters and thermocouples.

- Design and construct a new feeding system to minimize feed line blockages.

- Add a second Canty MINITEMP ${ }^{\mathrm{TM}}$ high temperature camera if possible with current nozzle configuration.

- Add a higher capacity regenerative blower so that -5 inwc can be maintained if testing at lower vapor space temperatures is required. Install an air intake filter and a relief valve to protect against damage from overheating. 
- Install longer thermocouples so that the connections do not overheat and they can be more easily tightened.

- Install a more robust lid for the OGCT if low vacuum testing will be performed.

- Modify the condensate overflow drain line to include a dip leg or other component to stabilize flow.

- If possible, move the pour heater slightly to help re-center the pour tube to reduce the possibility of glass making contact with the refractory and heater elements.

- If possible, replace $\mathrm{SiC}$ vapor space heater elements with a different type of heater that is not prone to breaking (e.g., high temperature cartridge heater).

- Modify the back pulse of the off-gas sample line so that it can be controlled by a solenoid valve if possible.

- Add a second set of viewing monitors to reduce frequency of screen changes.

\subsection{References}

1. T. Wagnon, "Defense Waste Processing Facility Alternate Reductant, Systems Engineering Evaluation," Savannah River Remediation, Aiken, SC, G-AES-S-00003, 2011.

2. A.S. Choi, "Melter Off-Gas Flammability Assessment for DWPF Alternate Reductant Flowsheet Options," Savannah River National Laboratoy, Aiken, SC, SRNL-STI-2011-00321, 2011.

3. D.P. Lambert, B.R. Pickenheim, M.E. Stone, J.D. Newell, and D.R. Best, "Glycolic-Formic Acid Flowsheet Final Report for Downselect Decision," Savannah River National Laboratory, Aiken, SC, SRNL-STI-2010, 00523, Rev. 1, 2011.

4. D.P. Lambert, M.E. Stone, J.D. Newell, D.R. Best, and J.R. Zamecnik, "Glycolic-Nitric Acid Flowsheet Demonstration of the DWPF Chemical Process Cell with Sludge and Supernate Simulants," Savannah River National Laboratory, Aiken, SC, SRNL-STI-2012-00018, Rev. 1, 2012.

5. T.L. Fellinger, D.P. Lambert, and M.E. Stone, "Technology Development Roadmap for NitricGlycolic Acid Flowsheet," Savannah River Remediation, Aiken, SC, SRR-STI-2012-00676, 2012.

6. E.W. Holtzscheiter, "Nitric-Glycolic Acid Flowsheet Melter Flammability Testing," Savannah River Remediation, Aiken, SC, HLW-DWPF-TTR-2013-0002, 2012.

7. T.L. Fellinger, E.W. Holtzscheiter, J.M. Bricker, A. Samadi-Dezfouli, and M.E. Smith, "Selection of Melter Platform for Performing Melter Off Gas Flammability for the Alternate Reductant Project," Savannah River Remediation, Aiken, SC, SRR-WSE-2012-00132, 2012.

8. F.C. Johnson, "Task Technical and Quality Assurance Plan for Alternative Reductant Melter Evaluation," Savannah River National Laboratory, Aiken, SC, SRL-RP-2012-00596, November 2012. 
9. F.C. Johnson, D.H. Miller, J.R. Zamecnik, and D.P. Lambert, "Alternate Reductant Cold Cap Evaluation Furnace Phase I Testing," Savannah River National Laboratory, Aiken, SC, SRNLSTI-2014-00005, 2014.

10. A.S. Choi, "2013 CEF Run - Phase I Data Analysis and Model Validation," Savannah River National Laboratory, Aiken, SC, SRNL-STI-2013-00705, 2014.

11. A.S. Choi, "DWPF Melter Off-Gas Flammability Model for the Nitric-Glycolic Acid Flowsheet," Savannah River National Laboratory, Aiken, SC, SRNL-STI-2014-00355, draft.

12. “786-A CEF Melter 2 Assembly," Savannah River National Laboratory, Aiken, SC, Drawing No. EES-23248-R1-017, current revision.

13. “999-W CEF Melter 2 Assembly,” Savannah River National Laboratory, Aiken, SC, Drawing No. EES-23248-R1-001, current revision.

14. “999-W CEF Melter 2 Crucible Details," Savannah River National Laboratory, Aiken, SC, Drawing No. EES-23248-R4-010, current revision.

15. “999-W CEF Melter 2 Crucible Weldment," Savannah River National Laboratory, Aiken, SC, Drawing No. EES-23248-R3-003, current revision.

16. “999-W CEF Melter 2 Lid Subweldments and Details 3," Savannah River National Laboratory, Aiken, SC, Drawing No. EES-23248-R3-013, current revision.

17. “999-W CEF Melter 2 Stand Weldment," Savannah River National Laboratory, Aiken, SC Drawing No. EES-23248-R3-002, current revision.

18. “999-W CEF Melter 2 Inspection Weldment," Savannah River National Laboratory, Aiken, SC, Drawing No. EES-23248-R3-004, current revision.

19. "999-W CEF Melter 2 Crucible Support Plate Weldment/Details," Savannah River National Laboratory, Aiken, SC, Drawing No. EES-23248-R3-005, current revision.

20. “786-A CEF Melter Lid Subweldments \& Details 2," Savannah River National Laboratory, Aiken, SC, Drawing No. EES-23248-R3-006, current revision.

21. “786-A CEF Melter 2 Lid Weldment,” Savannah River National Laboratory, Aiken, SC, Drawing No. EES-23248-R3-007, current revision.

22. “999-W CEF Melter 2 Miscellaneous Details," Savannah River National Laboratory, Aiken, SC, Drawing No. EES-23248-R4-008, current revision.

23. “999-W CEF Melter 2 Insulation Details," Savannah River National Laboratory, Aiken, SC, Drawing No. EES-23248-R4-009, current revision.

24. “999-W CEF Melter 2 Stand \& Related Details," Savannah River National Laboratory, Aiken, SC, Drawing No. EES-23248-R4-011, current revision.

25. “786-A CEF Melter Clamp \& Bubbler Assembly, Weldment \& Details," Savannah River National Laboratory, Aiken, SC, Drawing No. EES-23248-R1-012, current revision. 
26. “999-W CEF Melter 2 Lid Subweldments \& Details 1," Savannah River National Laboratory, Aiken, SC, Drawing No. EES-23248-R3-014, current revision.

27. "CEF Melter: Lid Heater Stuffing Box Details," Savannah River National Laboratory, Aiken, SC Drawing No. EES-23248-R4-015, current revision.

28. “786-A CEF Melter Detail Sheet Detail," Savannah River National Laboratory, Aiken, SC Drawing No. EES-23248-R3-016, current revision.

29. J. McIntosh, "Equipment Electrical Safety Evaluation," Savannah River National Laboratory, Aiken, SC, E-ESR-W-00005, Rev. 1, 2013.

30. J.I. Mickalonis, K.J. Imrich, C.M. Jantzen, T.R. Murphy, and J.E. Wilderman, "Corrosion Impact on Alternate Reductant on DWPF and Downstream Facilities," Savannah River National Laboratory, Aiken, SC, SRNL-STI-2014-00281, draft.

31. D.P. Lambert, "Batching Recipe: 100\% Koopman Acid Stoichiometry Nitric/Glycolic Acid Flowsheet Melter Feed," Savannah River National Laboratory, Aiken, SC, SRNL-L3100-201300036, Rev. 1, 2013.

32. D.P. Lambert, "Batching Recipe: 125\% Koopman Acid Stoichiometry Nitrc/Glycolic Acid Flowsheet Melter Feed," Savannah River National Laboratory, Aiken, SC, SRNL-L3100-201300064, Rev 1 (?), 2013.

33. D.C. Koopman, A.I. Fernandez, and B.R. Pickenheim, "Preliminary Evaluations of Two Proposed Stoichiometric Acid Equations," Savannah River National Laboratory, Aiken, SC, SRNL-L3100-2009-00146, 2009.

34. M.E. Stone, "Feed Preparation for Alternative Reductant Melter Testing," Savannah River National Laboratory, Aiken, SC, SRNL-L3100-2013-00109, 2013.

35. D.P. Lambert, "Batching Recipe: Nitric/Formic Acid Flowsheet Melter Feed," Savannah River National Laboratory, Aiken, SC, SRNL-L3100-2013-00021, 2013.

36. D.P. Lambert, "Acceptance of Harrell Batch SB6I 100\% Glycolic Nitric Acid Flowsheet SRAT Product,” Savannah River National Laboratory, Aiken, SC, SRNL-L3100-2013-00118, 2013.

37. D.P. Lambert, "Acceptance of Harrell Batch SB6I 125\% Glycolic Nitric Acid Flowsheet SRAT Product,” Savannah River National Laboratory, Aiken, SC, SRNL-L3100-2013-00146, 2013.

38. "Heat Treatment of Waste Slurries for Redox $\left(\mathrm{Fe}^{2+} / \mathrm{Fe}\right.$ Total) and Chemical Composition Measurement," Savannah River National Laboratory, Aiken, SC, ITS-0052, Latest Revision.

39. "Determining $\mathrm{Fe}^{2+} / \mathrm{Fe}^{3+}$ and $\mathrm{Fe}^{2+} / \mathrm{Fe}$ (Total) Using Uv Vis Spectrometer," Savannah River National Laboratory, Aiken, SC, ITS-0042, current revision.

40. "Weight Percent Solids Determination Using a Furnace or Oven," Savannah River National Laboratory, Aiken, SC, ITS-0078, current revision.

41. "Dissolution of Glass, Sludge and Slurry Samples Using $\mathrm{Na}_{2} \mathrm{O}_{2} / \mathrm{NaOH} / \mathrm{HCl}$," Savannah River National Laboratory, Aiken, SC, ITS-0040, current revision. 
42. "Lithium Metaborate Fusion Preparation," Savannah River National Laboratory, Aiken, SC, ITS0071, current revision.

43. "Lithium Tetraborate Fusion Preparation," Savannah River National Laboratory, Aiken, SC, ITS0070, current revision.

44. "Aqua Regia Dissolutions of Passivated Hydride Materals," Savannah River National Laboratory, Aiken, SC, ITS-WI-0036, current revision.

45. "Sample Dissolution Using Potassium Hydroxide Fusion," Savannah River National Laboratory, Aiken, SC, ITS-0035, current revision.

46. "Inductively Coupled Plasma-Atomic Emission Spectrometer Agilent 730 ES," Savannah River National Laboratory, Aiken, SC, ITS-0079, current revision.

47. "Anion Analysis Using the Dionex DX-500 and ICS-5000 Ion Chromatograph," Savannah River National Laboratory, Aiken, SC, ITS-0027, current revision.

48. "Analysis of Ions in Solutions Using a Dionex Ics3000 Ion Chromatography System " Savannah River National Laboratory, Aiken, SC, ADS-2310, current revision.

49. "Model 1030 Sample Analysis," Savannah River Remediation, Aiken, SC, SW4-15.202 Section 6.11 , current revision.

50. "Gas Chromatography/Mass Spectrometry for Semivolatile Organics Including Polychlorinated Biphenyls," Savannah River National Laboratory, Aiken, SC, ADS-2657, current revision.

51. J.W. Amoroso and J.R. Zamecnik, "Measurement of Offgas Species from Thermal Decomposition of Simulated DWPF Melter Feed," Savannah River National Laboratory, Aiken, SC, SRNL-STI-2014-00286, 2014.

52. F.C. Johnson, "Alternate Reductant Cold Cap Evaluation Furnace (CEF) Phase II Data," Savannah River National Laboratory, Aiken, SC, SRNL-L3100-2014-00081, 2014.

53. J.D. Newell, D.P. Lambert, and J.R. Zamecnik, "Impact of Scaling on the Glycolic-Nitric Acid Flowsheet," Savannah River National Laboratory, Aiken, SC, SRNL-STI-2014-00306, draft.

54. D.H. Miller, K. Fox, B.R. Pickenheim, and M.E. Stone, "Melter Rate Furnace Testing for Sludge Batch 5 Frit Optimization," Savannah River National Laboratory, Aiken, SC, SRNS-STI-200800092, 2008.

55. M.E. Smith and D.H. Miller, "Maximizing SB3 Waste Throughput Melt Rate Tests," Savannah River National Laboratory, Aiken, SC, WSRC-TR-2005-00456, 2005.

56. A.S. Choi, D.H. Miller, and D.M. Immel, "Determination of HLW Glass Melt Rate Using X-Ray Computed Tomography (Ct)," Savannah River National Laboratory, Aiken, SC, SRNL-STI2010-00767, 2010.

57. W.L. Daugherty, "Creep Life Assessment of Inconel 690 CEF Melter 2 Vessel," Savannah River National Laboratory, Aiken, SC, SRNL-L4400-2012-00030, 2012. 
58. J. Coughlin, "CEF 2 Tension Rod Structural Calculation, Rev. B," Savannah River National Laboratory, Aiken, SC, Job-23248, 2013.

59. J.R. Zamecnik, to F.C. Johnson, “CEF 2 Offgas Organics,” July 23, 2014, Email.

60. J.R. Zamecnik, to F.C. Johnson, A.S. Choi, and D.H. McGuire, "CEF Phase 2 Offgas Carbon Tube Samples," June 17, 2014, Email.

61. C.M. Jantzen and F.C. Johnson, "Impacts of Antifoam Additions and Argon Bubbling on Defense Waste Processing Facility (DWPF) Reduction/Oxidation (Redox)," Savannah River National Laboratory, Aiken, SC, SRNL-STI-2011-00652, 2012.

62. F.C. Johnson and D.R. Click, "Redox Analysis of a Sb6 Pour Stream Sample and Melter Feed Tank Batch 558 Sample," Savannah River National Laboratory, Aiken, SC, SRNL-L3100-201100092, May 2011. 
SRNL-STI-2014-00157

Revision 0

Appendix A. Supplementary Figures and Tables 
Table A-1. Sealed Crucible REDOX Remediation Results (100\%)

\begin{tabular}{|c|c|c|c|c|c|c|}
\hline Sample ID & Lab ID & $\mathrm{Fe}^{2+}$ & $\mathrm{Fe}^{3+}$ & $\sum \mathbf{F e}$ & $\mathrm{Fe}^{2+} / \mathrm{Fe}^{3+}$ & $\mathrm{Fe}^{2+} / \sum \mathrm{Fe}$ \\
\hline EA & EA & 0.082 & 0.365 & 0.447 & 0.225 & 0.183 \\
\hline Baseline-1 (A) & $\mathrm{S}-750$ & 0.202 & 0.248 & 0.450 & 0.815 & 0.449 \\
\hline Baseline-1 (B) & $\mathrm{S}-750$ & 0.202 & 0.249 & 0.451 & 0.811 & 0.448 \\
\hline Baseline-2 (A) & S-751 & 0.240 & 0.243 & 0.483 & 0.988 & 0.497 \\
\hline Baseline-2 (B) & S-751 & 0.239 & 0.244 & 0.483 & 0.980 & 0.495 \\
\hline Baseline-3 (A) & S-752 & 0.242 & 0.241 & 0.483 & 1.004 & 0.501 \\
\hline Baseline-3 (B) & S-752 & 0.242 & 0.240 & 0.482 & 1.008 & 0.502 \\
\hline Lo Na-1 (A) & S-753 & 0.091 & 0.332 & 0.423 & 0.274 & 0.215 \\
\hline Lo Na-1 (B) & S-753 & 0.092 & 0.334 & 0.426 & 0.275 & 0.216 \\
\hline Lo Na-2 (A) & S-754 & 0.117 & 0.333 & 0.450 & 0.351 & 0.260 \\
\hline Lo Na-2 (B) & S-754 & 0.116 & 0.336 & 0.452 & 0.345 & 0.257 \\
\hline Lo Na-3 (A) & S-755 & 0.128 & 0.321 & 0.449 & 0.399 & 0.285 \\
\hline Lo Na-3 (B) & S-755 & 0.127 & 0.321 & 0.448 & 0.396 & 0.283 \\
\hline Med Na-1 (A) & S-756 & $<0.010$ & 0.531 & 0.531 & All Fe ${ }^{3+}$ & $\mathrm{All} \mathrm{Fe}^{3+}$ \\
\hline Med Na-1 (B) & S-756 & $<0.010$ & 0.533 & 0.533 & All Fe ${ }^{3+}$ & $\mathrm{All} \mathrm{Fe}^{3+}$ \\
\hline $\operatorname{Med~Na-2(A)}$ & S-757 & $<0.010$ & 0.533 & 0.533 & All Fe ${ }^{3+}$ & $\mathrm{All} \mathrm{Fe}^{3+}$ \\
\hline Med Na-2 (B) & S-757 & $<0.010$ & 0.530 & 0.530 & All Fe ${ }^{3+}$ & $\mathrm{All} \mathrm{Fe}^{3+}$ \\
\hline Med NA-3 (A) & S-758 & 0.011 & 0.488 & 0.499 & 0.023 & 0.022 \\
\hline Med NA-3 (B) & S-758 & 0.010 & 0.491 & 0.501 & 0.020 & 0.020 \\
\hline Hi Na-1 (A) & S-759 & $<0.010$ & 0.497 & 0.497 & All Fe ${ }^{3+}$ & $\mathrm{All} \mathrm{Fe}^{3+}$ \\
\hline Hi Na-1 (B) & S-759 & $<0.010$ & 0.498 & 0.498 & All Fe ${ }^{3+}$ & $\mathrm{All} \mathrm{Fe}^{3+}$ \\
\hline $\mathrm{Hi} \mathrm{Na}-2$ (A) & S-760 & $<0.010$ & 0.493 & 0.493 & All Fe ${ }^{3+}$ & $\mathrm{All} \mathrm{Fe}^{3+}$ \\
\hline $\mathrm{Hi} \mathrm{Na-2} \mathrm{(B)}$ & S-760 & $<0.010$ & 0.494 & 0.494 & All Fe ${ }^{3+}$ & $\mathrm{All} \mathrm{Fe} e^{3+}$ \\
\hline Hi Na-3 (A) & S-761 & $<0.010$ & 0.529 & 0.529 & All Fe ${ }^{3+}$ & $\mathrm{All} \mathrm{Fe}^{3+}$ \\
\hline Hi Na-3 (B) & S-761 & $<0.010$ & 0.530 & 0.530 & All Fe ${ }^{3+}$ & $\mathrm{All} \mathrm{Fe}^{3+}$ \\
\hline
\end{tabular}


Table A-2. Sealed Crucible REDOX Remediation Results (125\%)

\begin{tabular}{|c|c|c|c|c|c|c|}
\hline Sample ID & Lab ID & $\mathrm{Fe}^{2+}$ & $\mathrm{Fe}^{3+}$ & $\sum \mathbf{F e}$ & $\mathrm{Fe}^{2+} / \mathrm{Fe}^{3+}$ & $\mathrm{Fe}^{2+} / \sum \mathrm{Fe}$ \\
\hline EA & EA & 0.083 & 0.363 & 0.446 & 0.229 & 0.186 \\
\hline Baseline-1 (A) & S-766 & $<0.010$ & 0.501 & 0.501 & All Fe $\mathrm{Fe}^{3+}$ & All Fe $\mathrm{Fe}^{3+}$ \\
\hline Baseline-1 (B) & S-766 & $<0.010$ & 0.504 & 0.504 & All Fe $\mathrm{Fe}^{3+}$ & All Fe ${ }^{3+}$ \\
\hline Baseline-2 (A) & S-767 & $<0.010$ & 0.516 & 0.516 & All $\mathrm{Fe}^{3+}$ & All Fe $\mathrm{Fe}^{3+}$ \\
\hline Baseline-2 (B) & S-767 & $<0.010$ & 0.518 & 0.518 & All $\mathrm{Fe}^{3+}$ & All $\mathrm{Fe}^{3+}$ \\
\hline Baseline-3 (A) & S-768 & $<0.010$ & 0.513 & 0.513 & All $\mathrm{Fe}^{3+}$ & All Fe $\mathrm{Fe}^{3+}$ \\
\hline Baseline-3 (B) & S-768 & $<0.010$ & 0.512 & 0.512 & All $\mathrm{Fe}^{3+}$ & All $\mathrm{Fe}^{3+}$ \\
\hline Lo Na-1 (A) & S-769 & 0.052 & 0.383 & 0.435 & 0.136 & 0.120 \\
\hline Lo Na-1 (B) & S-769 & 0.053 & 0.382 & 0.435 & 0.139 & 0.122 \\
\hline Lo Na-2 (A) & S-770 & 0.025 & 0.456 & 0.481 & 0.055 & 0.052 \\
\hline Lo Na-2 (B) & S-770 & 0.025 & 0.457 & 0.482 & 0.055 & 0.052 \\
\hline Lo Na-3 (A) & S-771 & 0.055 & 0.382 & 0.437 & 0.144 & 0.126 \\
\hline Lo Na-3 (B) & S-771 & 0.055 & 0.383 & 0.438 & 0.144 & 0.126 \\
\hline Med Na-1 (A) & S-772 & 0.226 & 0.250 & 0.476 & 0.904 & 0.475 \\
\hline Med Na-1 (B) & S-772 & 0.225 & 0.251 & 0.476 & 0.896 & 0.473 \\
\hline Med Na-2 (A) & S-773 & 0.226 & 0.240 & 0.466 & 0.942 & 0.485 \\
\hline Med Na-2 (B) & S-773 & 0.226 & 0.242 & 0.468 & 0.934 & 0.483 \\
\hline Med NA-3 (A) & S-774 & 0.224 & 0.251 & 0.475 & 0.892 & 0.472 \\
\hline Med NA-3 (B) & S-774 & 0.225 & 0.249 & 0.474 & 0.904 & 0.475 \\
\hline $\mathrm{HiNa}-1$ (A) & S-775 & 0.311 & 0.199 & 0.510 & 1.563 & 0.610 \\
\hline $\mathrm{Hi} \mathrm{Na}-1$ (B) & S-775 & 0.313 & 0.200 & 0.513 & 1.565 & 0.610 \\
\hline $\mathrm{HiNa}-2(\mathrm{~A})$ & S-776 & 0.263 & 0.210 & 0.473 & 1.252 & 0.556 \\
\hline $\mathrm{Hi} \mathrm{Na}-2$ (B) & S-776 & 0.263 & 0.211 & 0.474 & 1.246 & 0.555 \\
\hline $\mathrm{HiNa}-3$ (A) & S-777 & 0.310 & 0.223 & 0.533 & 1.390 & 0.582 \\
\hline $\mathrm{Hi} \mathrm{Na}-3(\mathrm{~B})$ & S-777 & 0.312 & 0.219 & 0.531 & 1.425 & 0.588 \\
\hline
\end{tabular}




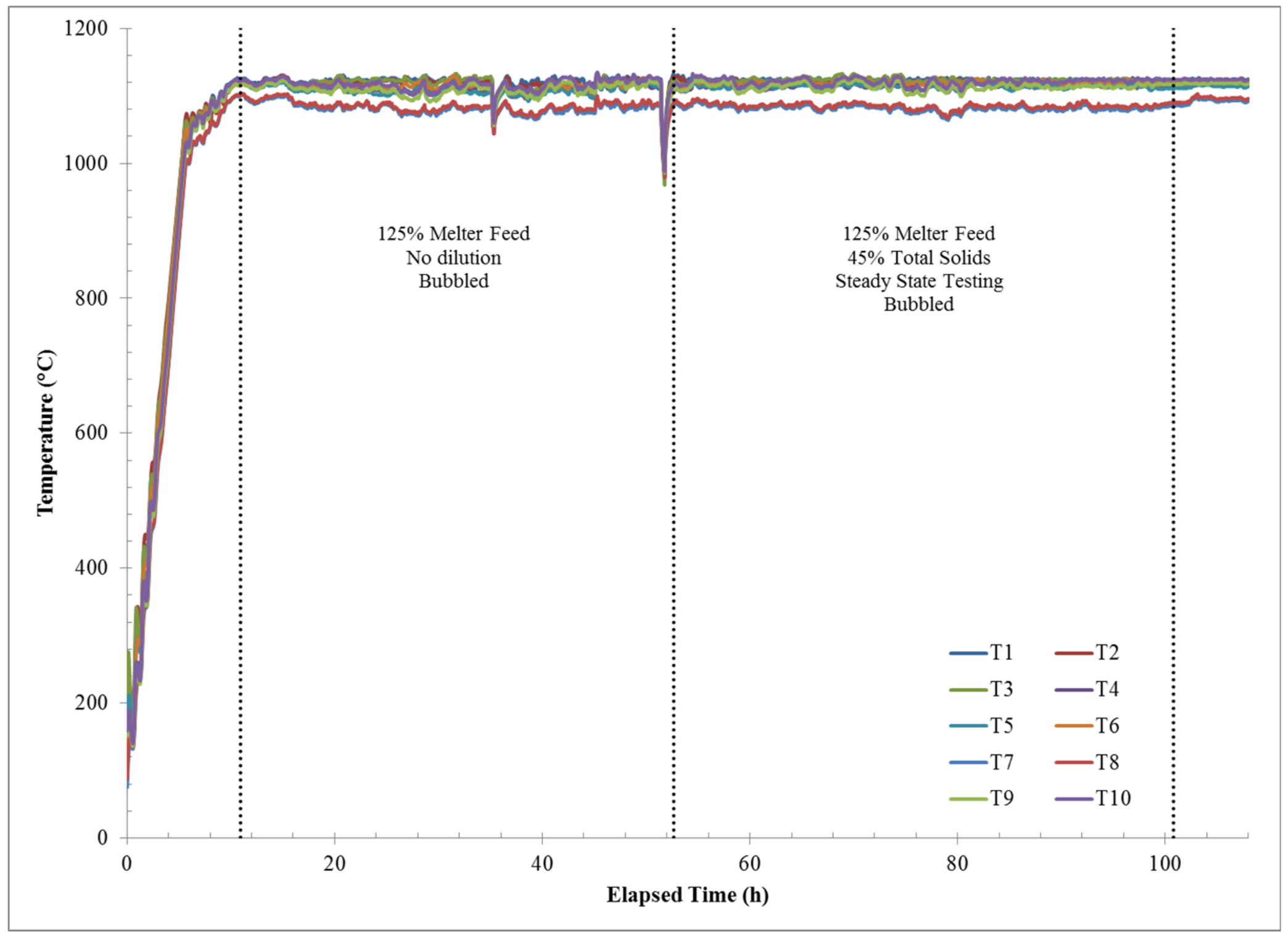

Figure A-1. Melter bottom (T1, T2) and melter side (T3-T10) thermocouple temperatures (elapsed time=0 at 12:00 February 24, 2014). 


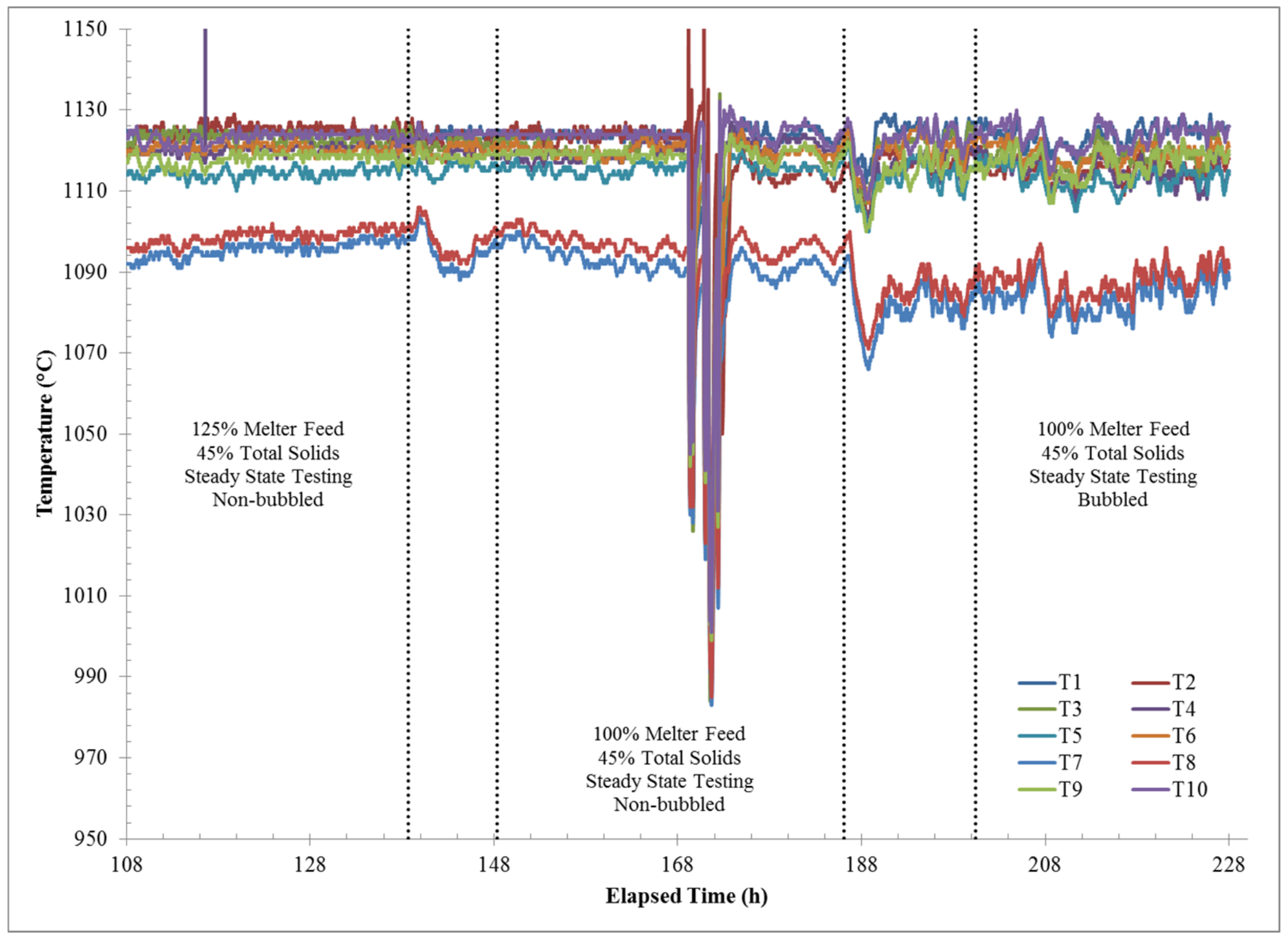

Figure A-2. Melter bottom (T1, T2) and melter side (T3-T10) thermocouple temperatures (elapsed time=108 at 00:00 March 1, 2014). 


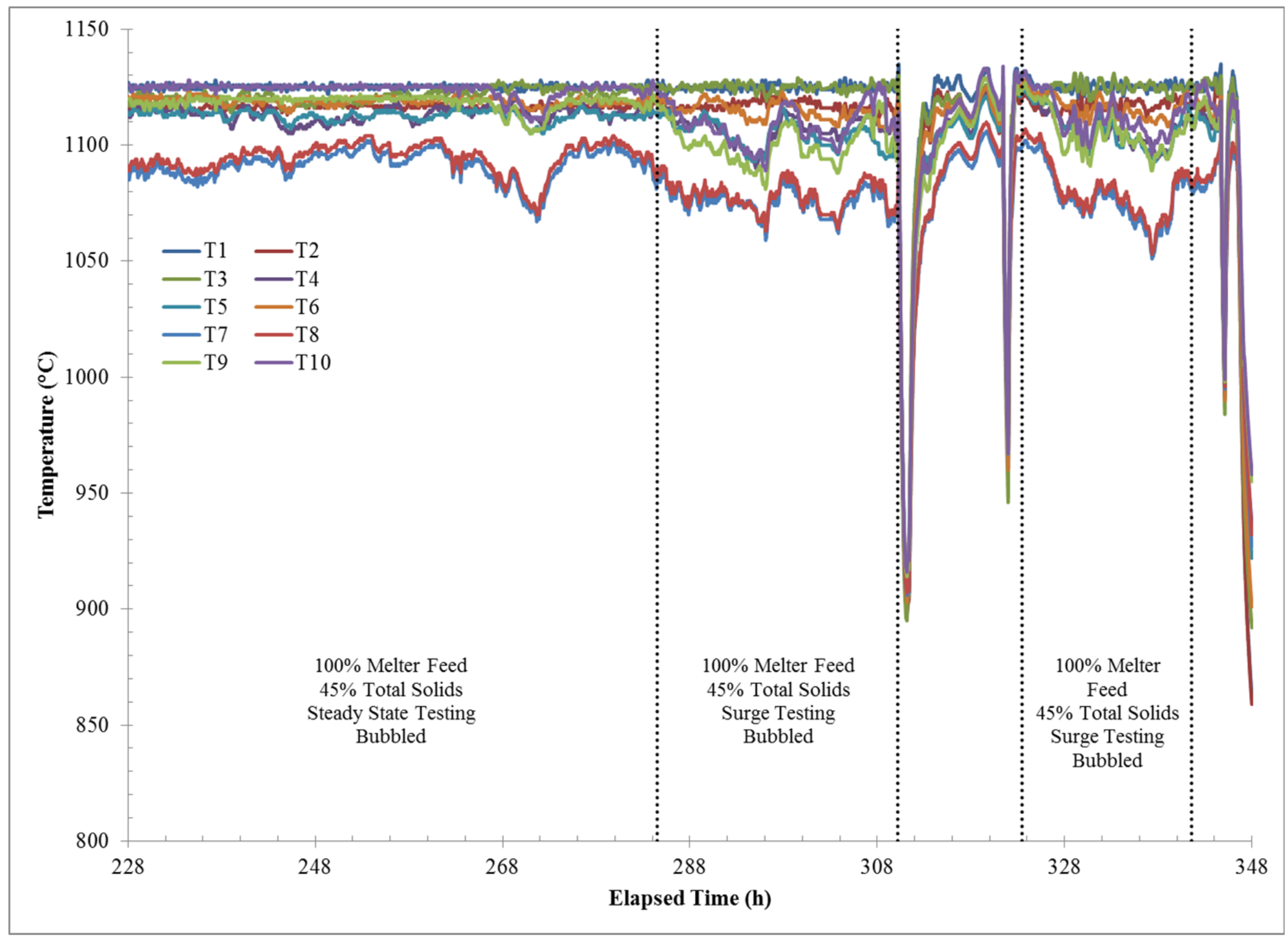

Figure A-3. Melter bottom (T1, T2) and melter side (T3-T10) thermocouple temperatures (elapsed time=228 at 00:00 March 6, 2014). 


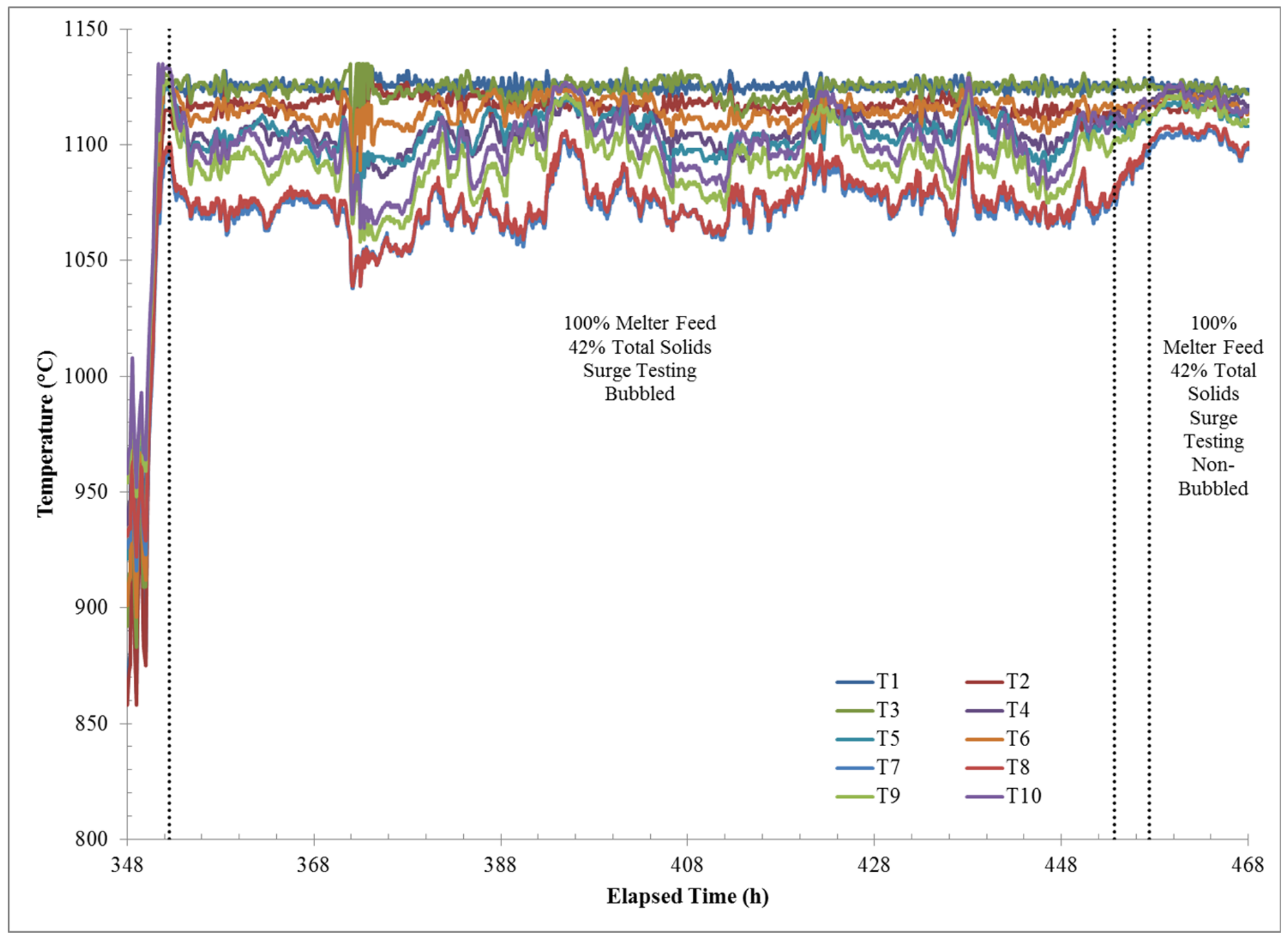

Figure A-4. Melter bottom (T1, T2) and melter side (T3-T10) thermocouple temperatures (elapsed time=348 at 00:00 March 11, 2014). 


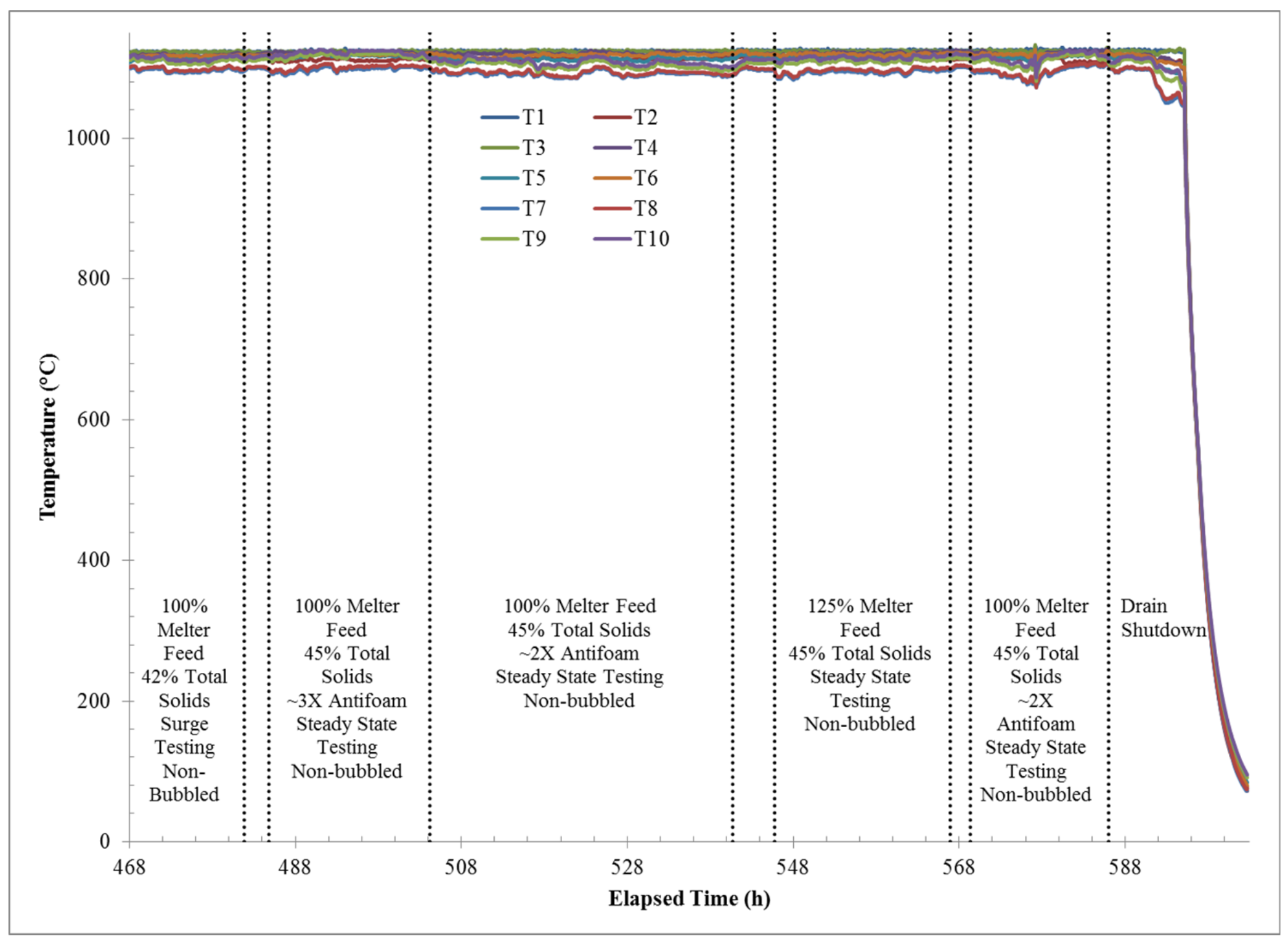

Figure A-5. Melter bottom (T1, T2) and melter side (T3-T10) thermocouple temperatures (elapsed time=468 at 00:00 March 16, 2014). 


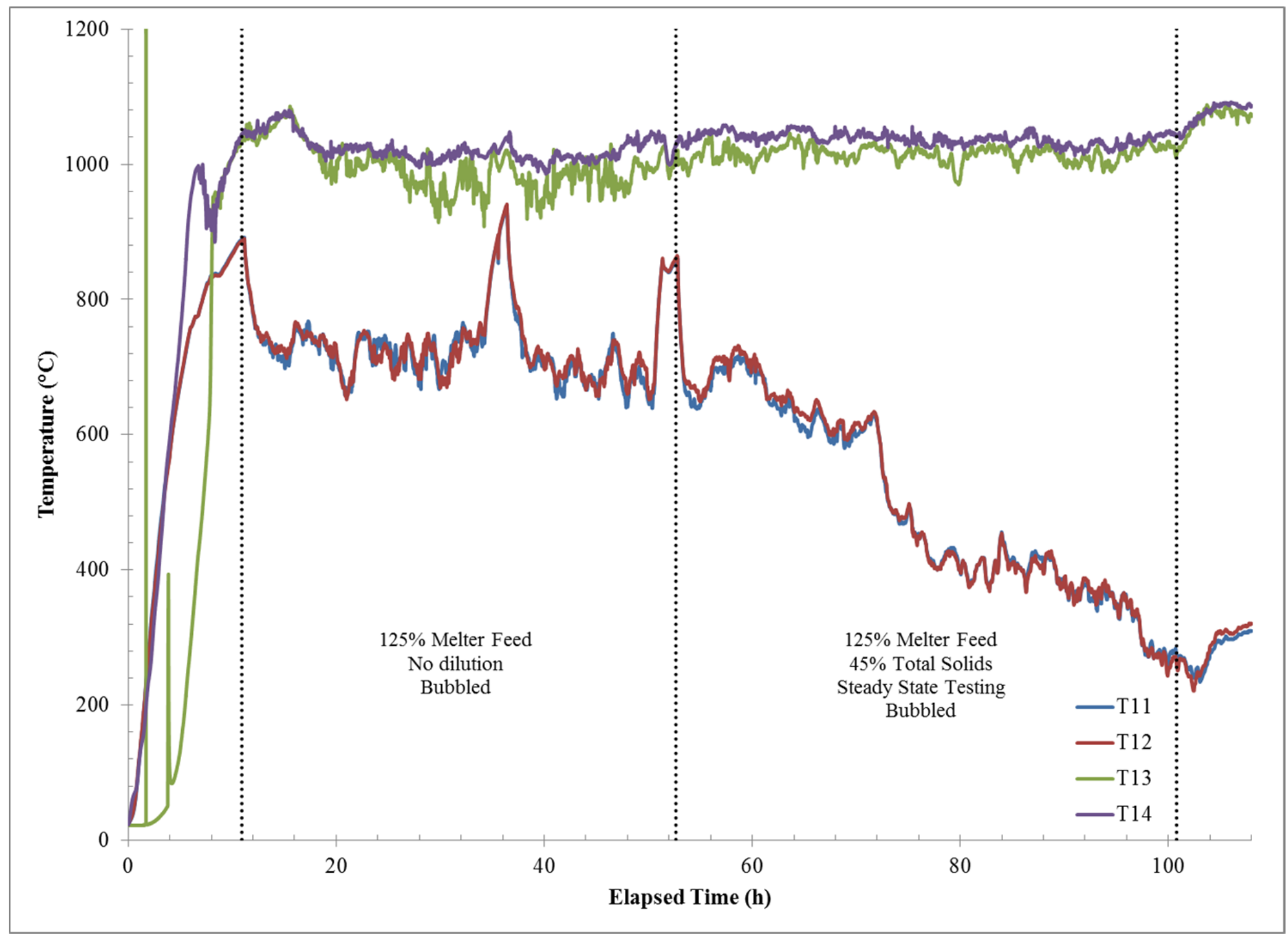

Figure A-6. Vapor space (T11,T12) and melt pool (T13, T14) thermocouple temperatures (elapsed time=0 at 12:00 February 24, 2014). 


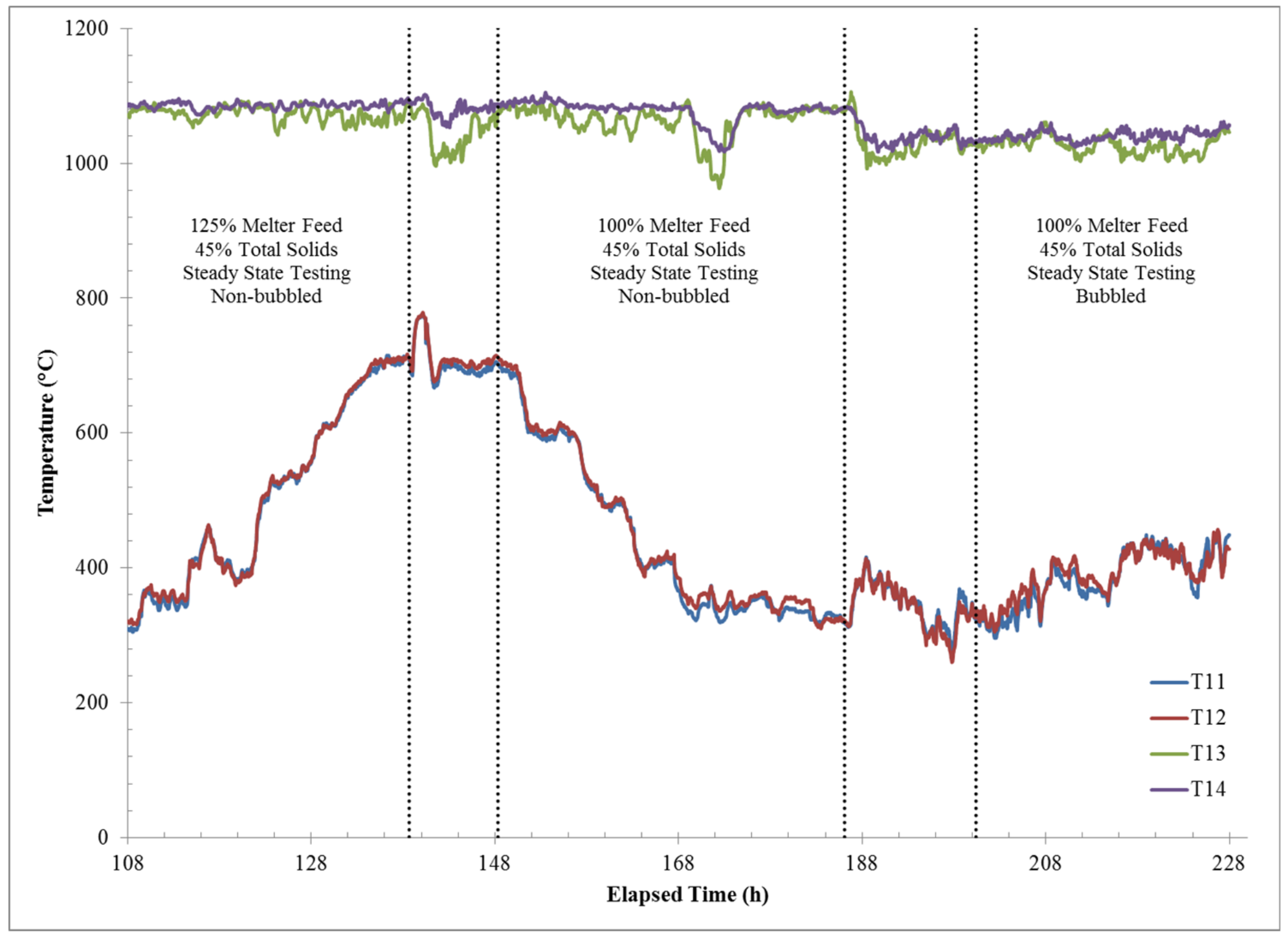

Figure A-7. Vapor space (T11,T12) and melt pool (T13, T14) thermocouple temperatures (elapsed time=108 at 00:00 March 1, 2014). 


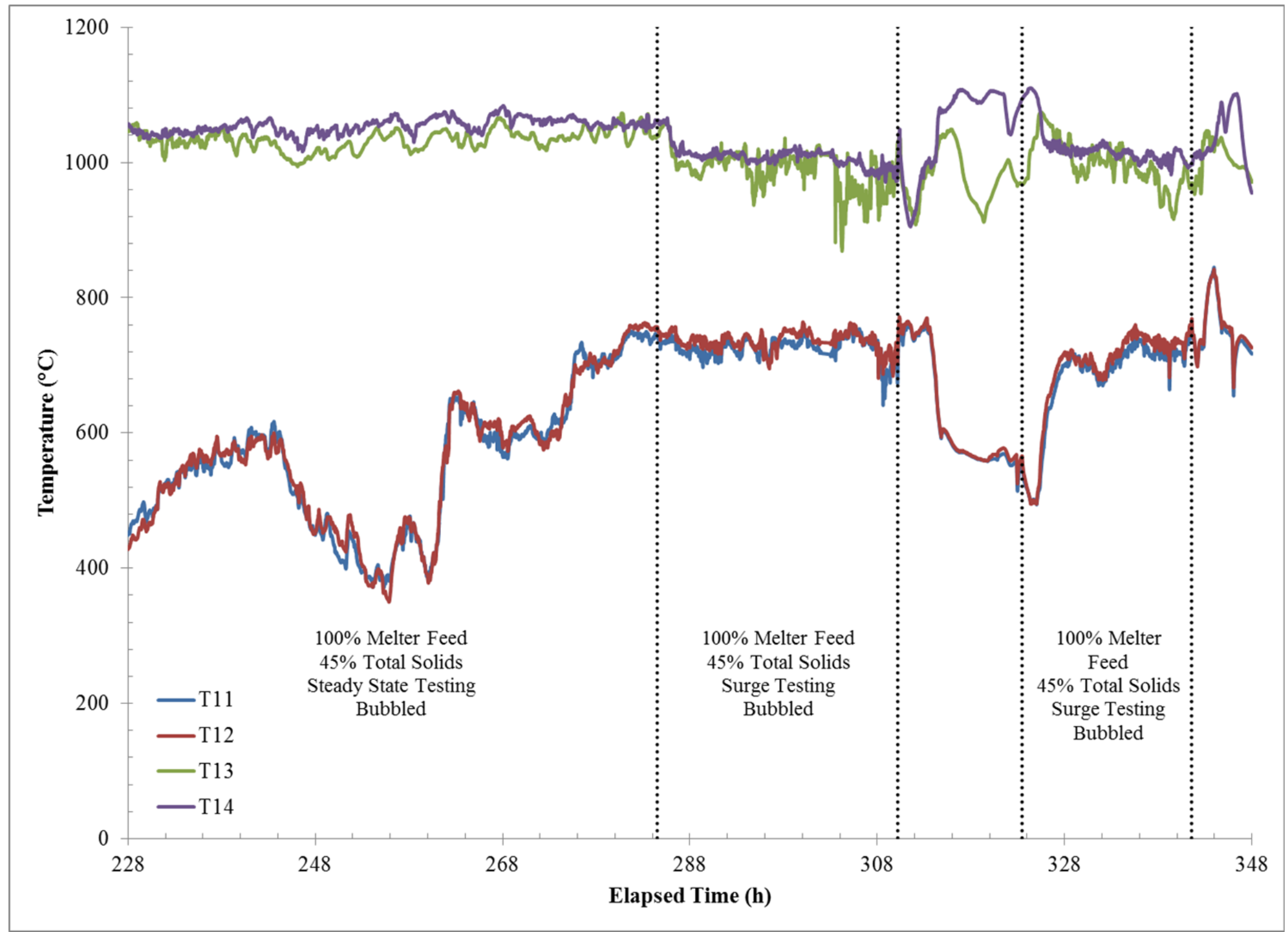

Figure A-8. Vapor space (T11,T12) and melt pool (T13, T14) thermocouple temperatures (elapsed time=228 at 00:00 March 6, 2014). 


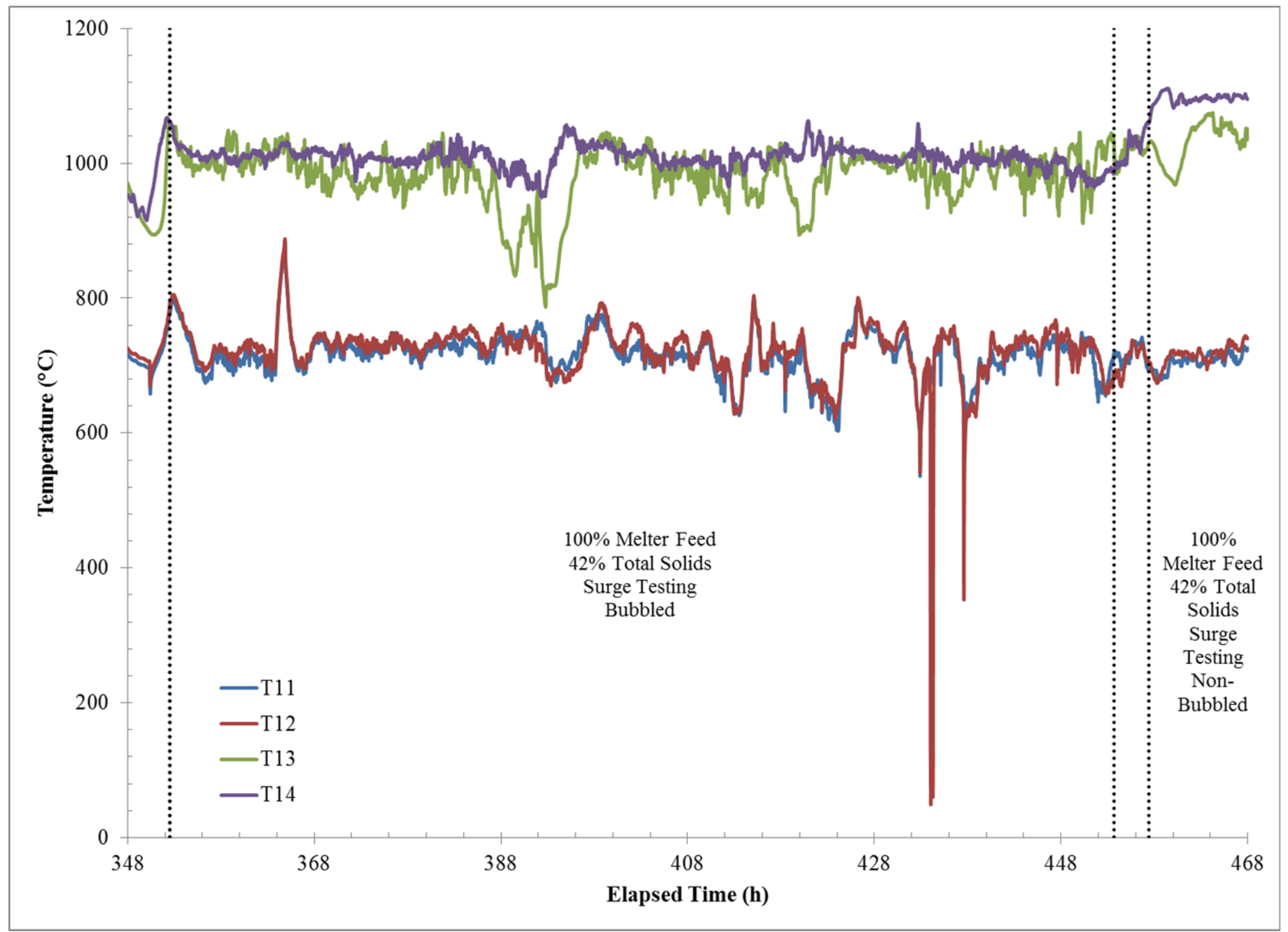

Figure A-9. Vapor space (T11,T12) and melt pool (T13, T14) thermocouple temperatures (elapsed time=348 at 00:00 March 11, 2014). 


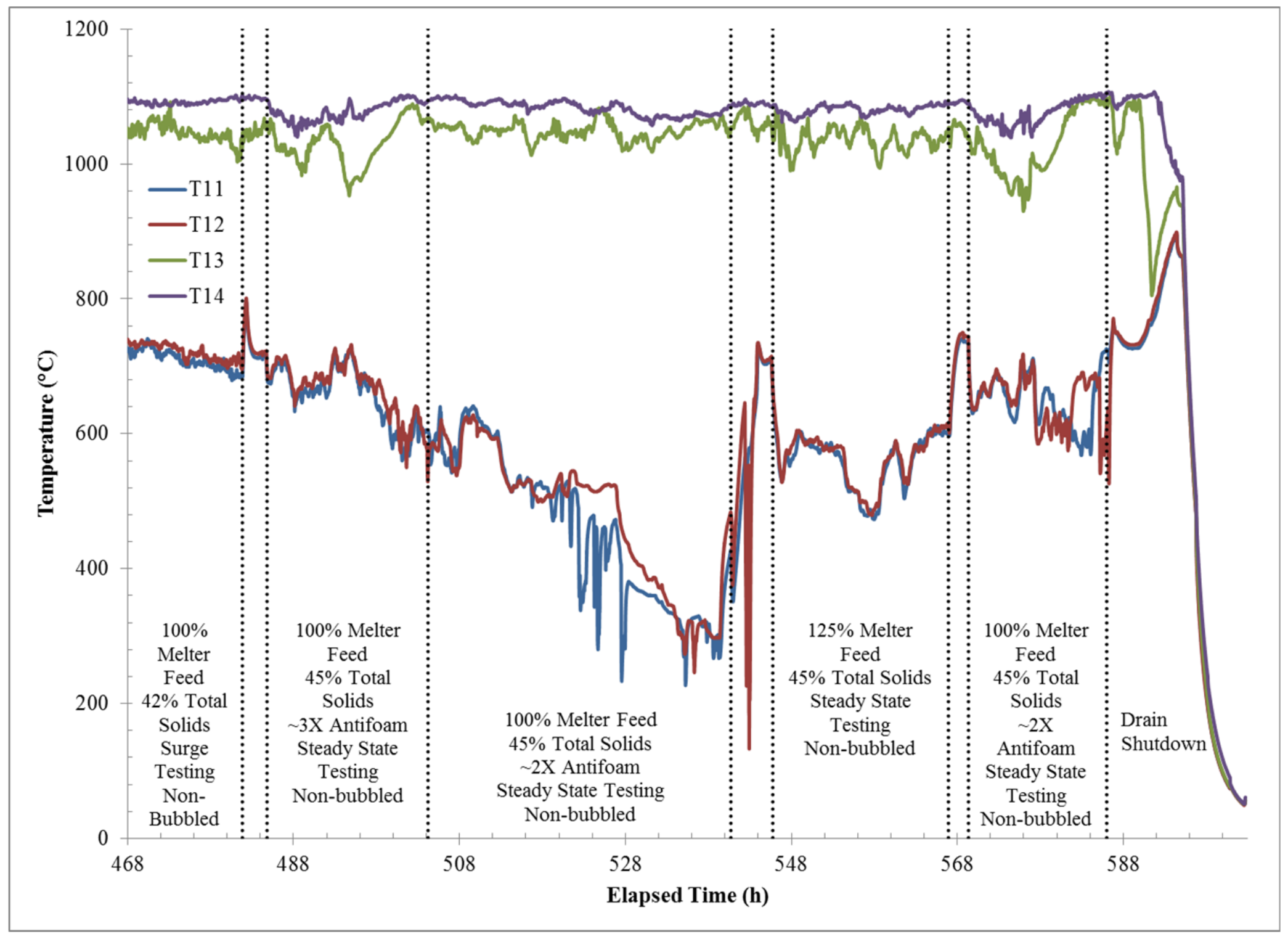

Figure A-10. Vapor space (T11,T12) and melt pool (T13, T14) thermocouple temperatures (elapsed time=468 at 00:00 March 16, 2014). 


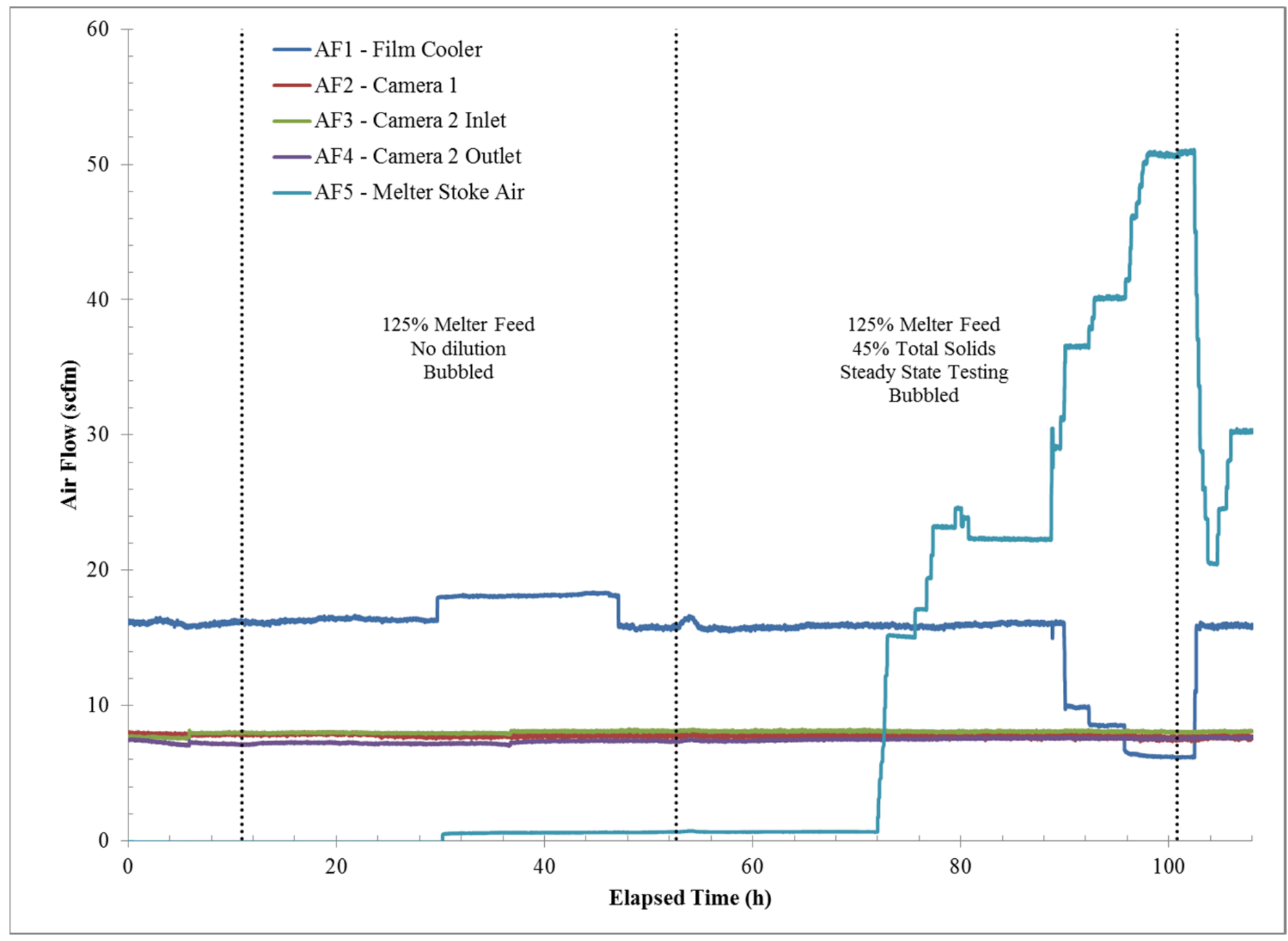

Figure A-11. Air flows (elapsed time=0 at 12:00 February 24, 2014). 


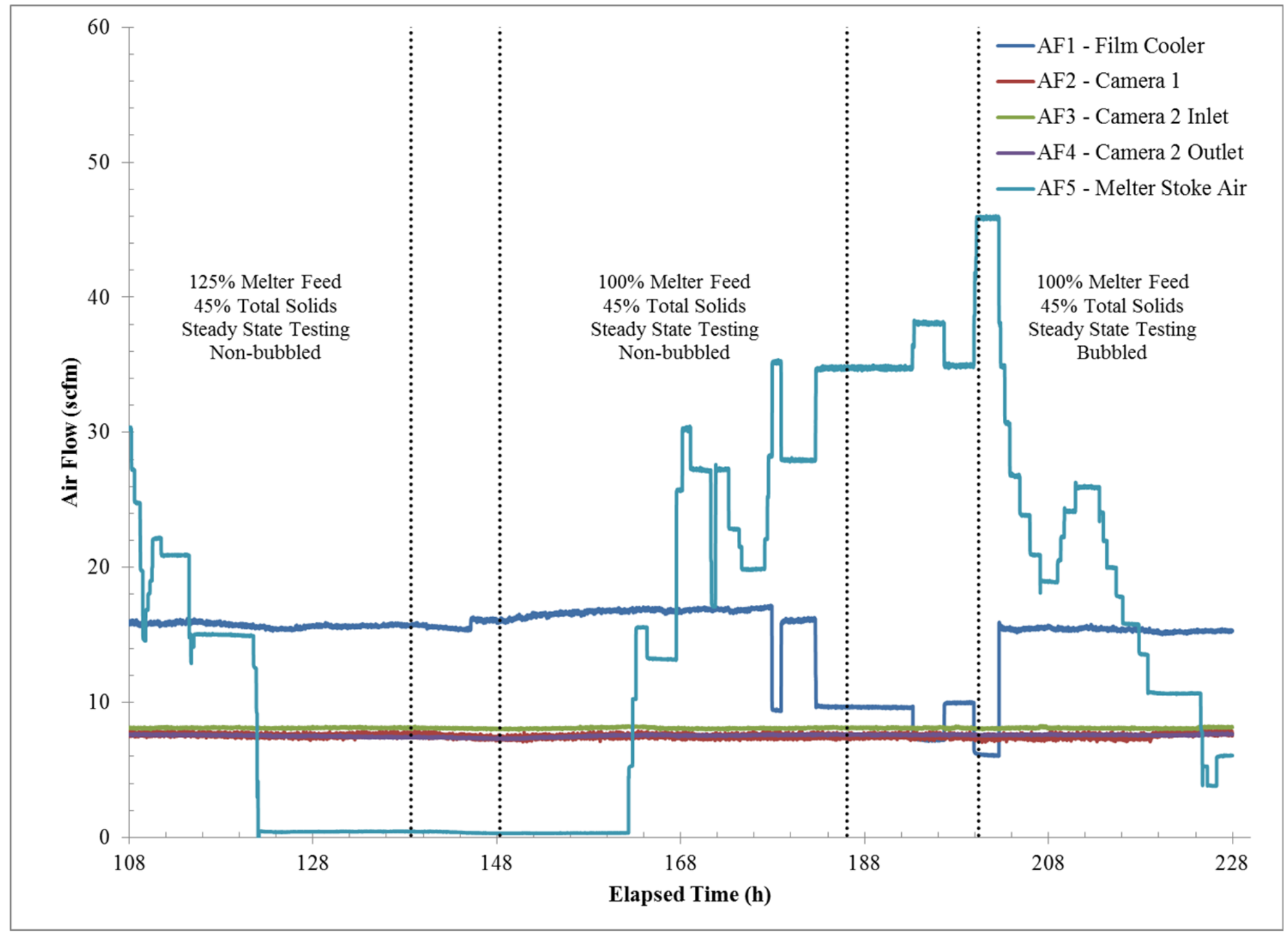

Figure A-12. Air flows (elapsed time=108 at 00:00 March 1, 2014). 


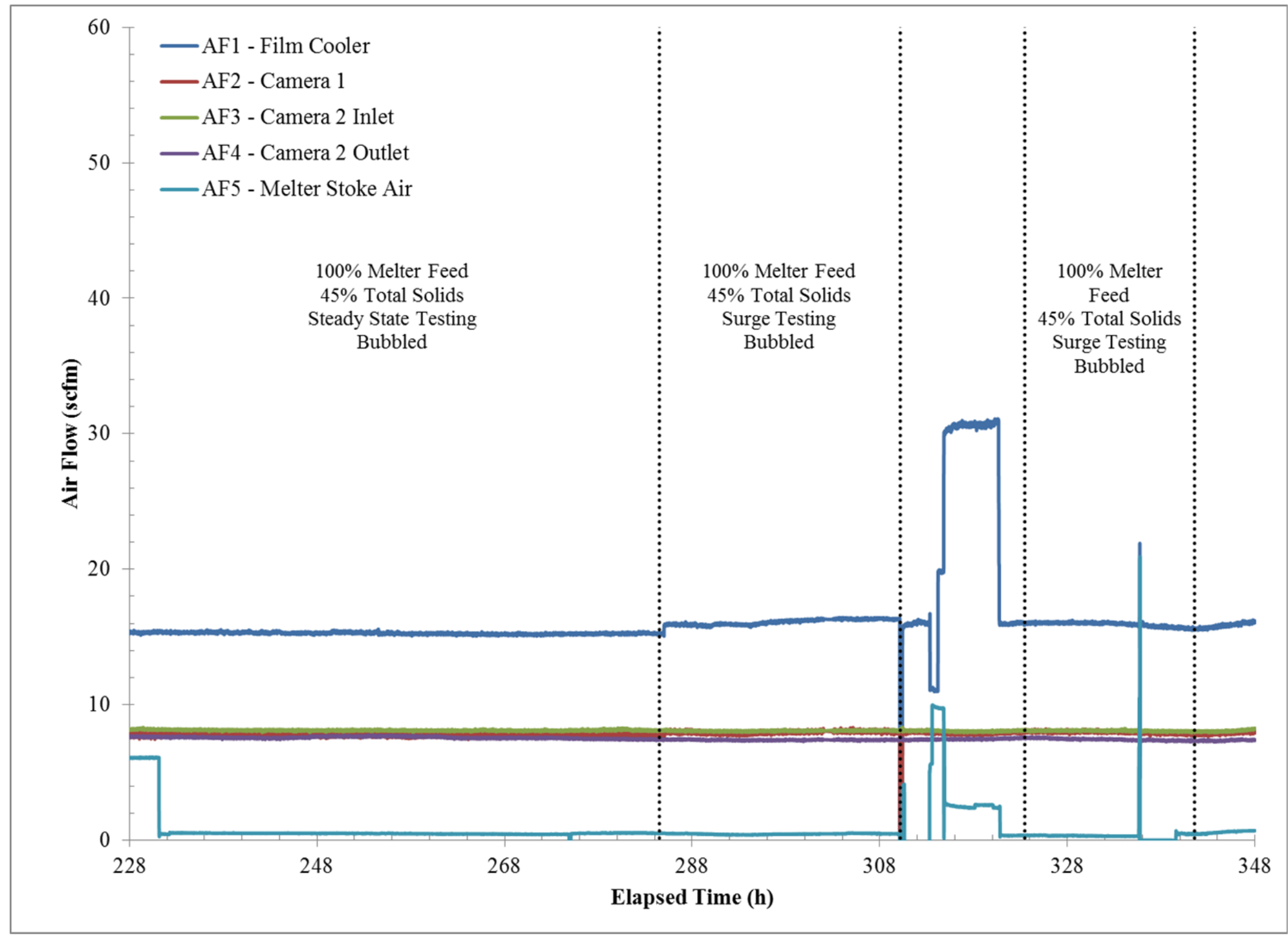

Figure A-13. Air flows (elapsed time=228 at 00:00 March 6, 2014). 


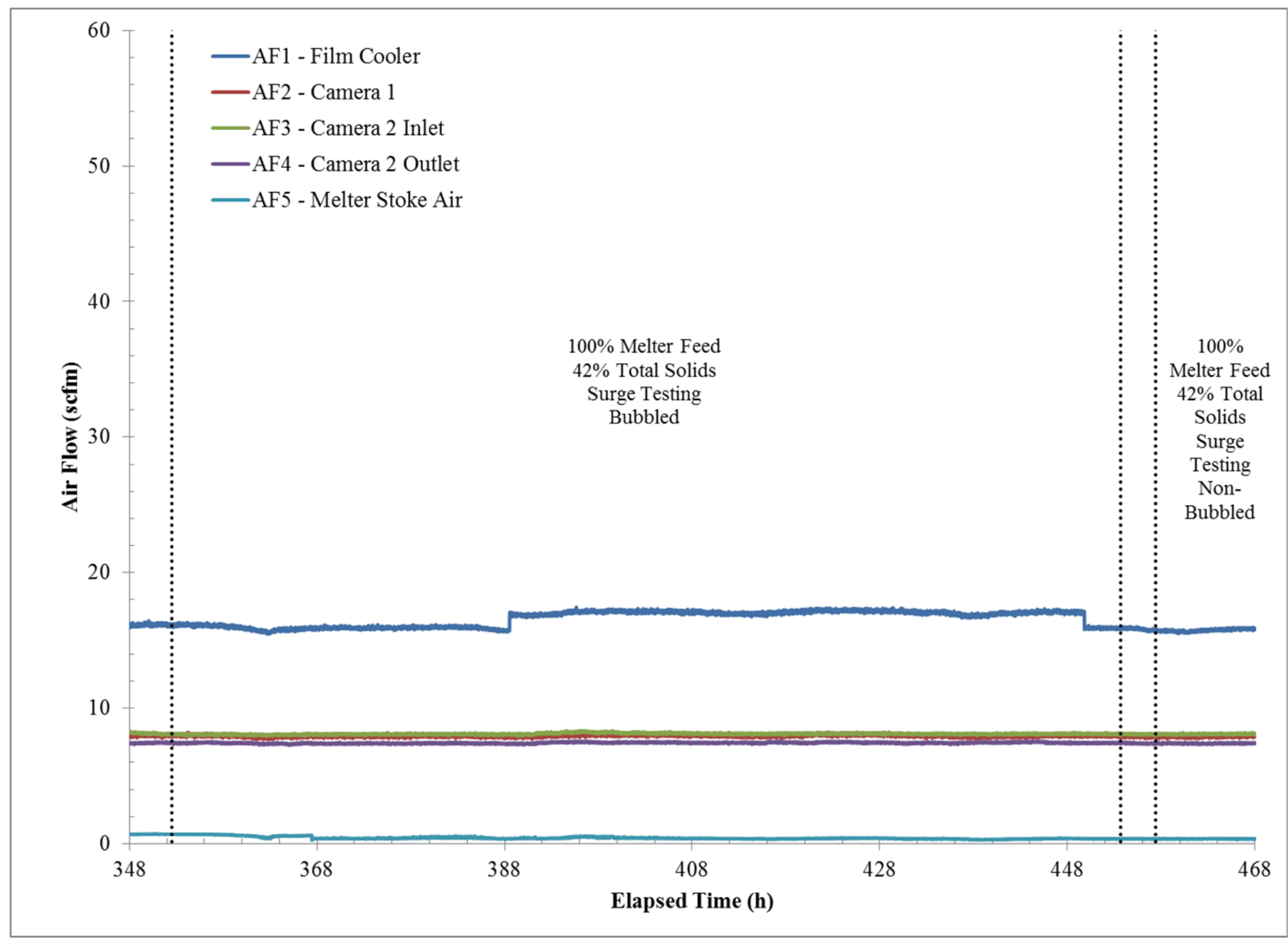

Figure A-14. Air flows (elapsed time=348 at 00:00 March 11, 2014). 


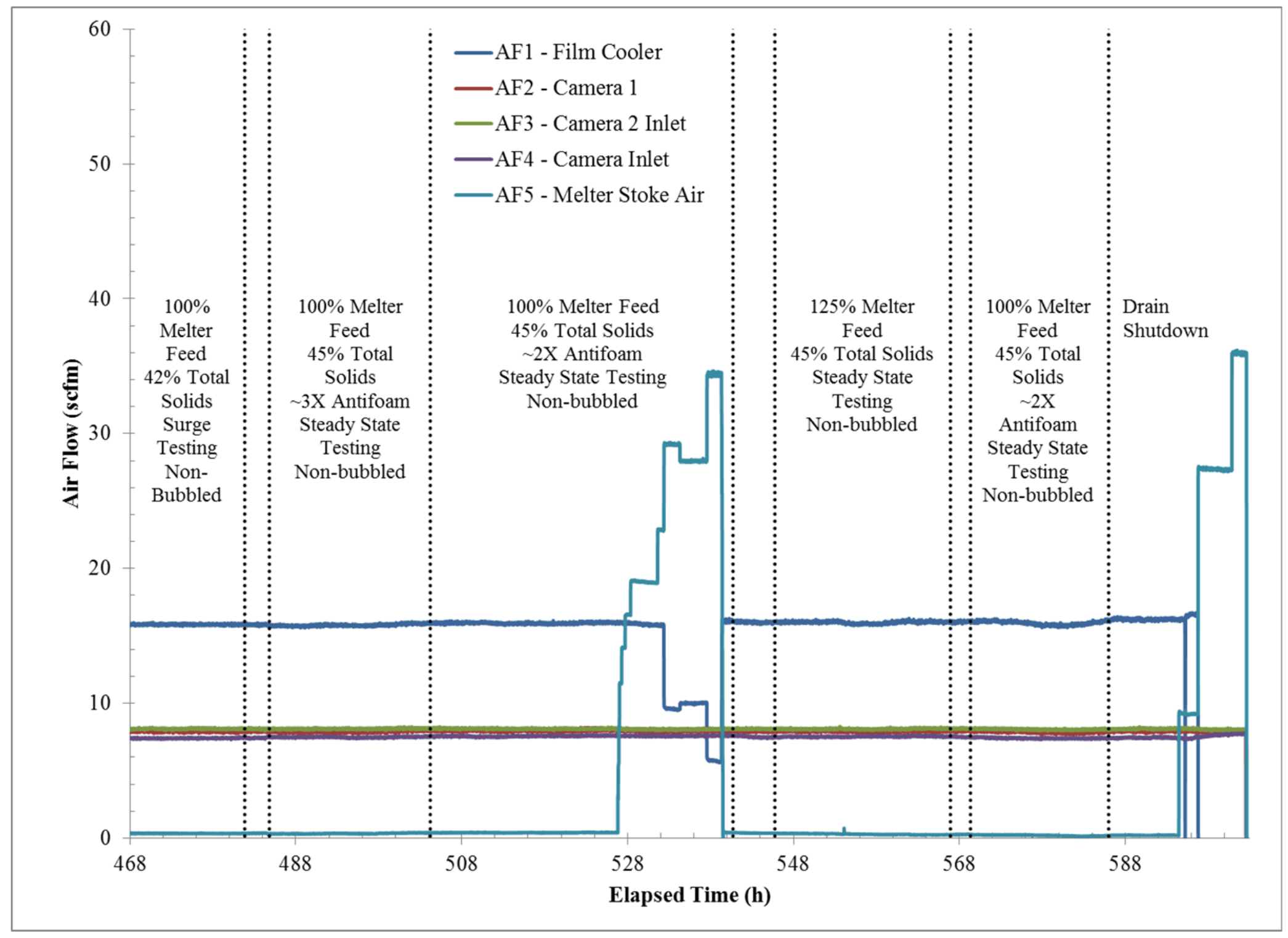

Figure A-15. Air flows (elapsed time=468 at 00:00 March 16, 2014). 


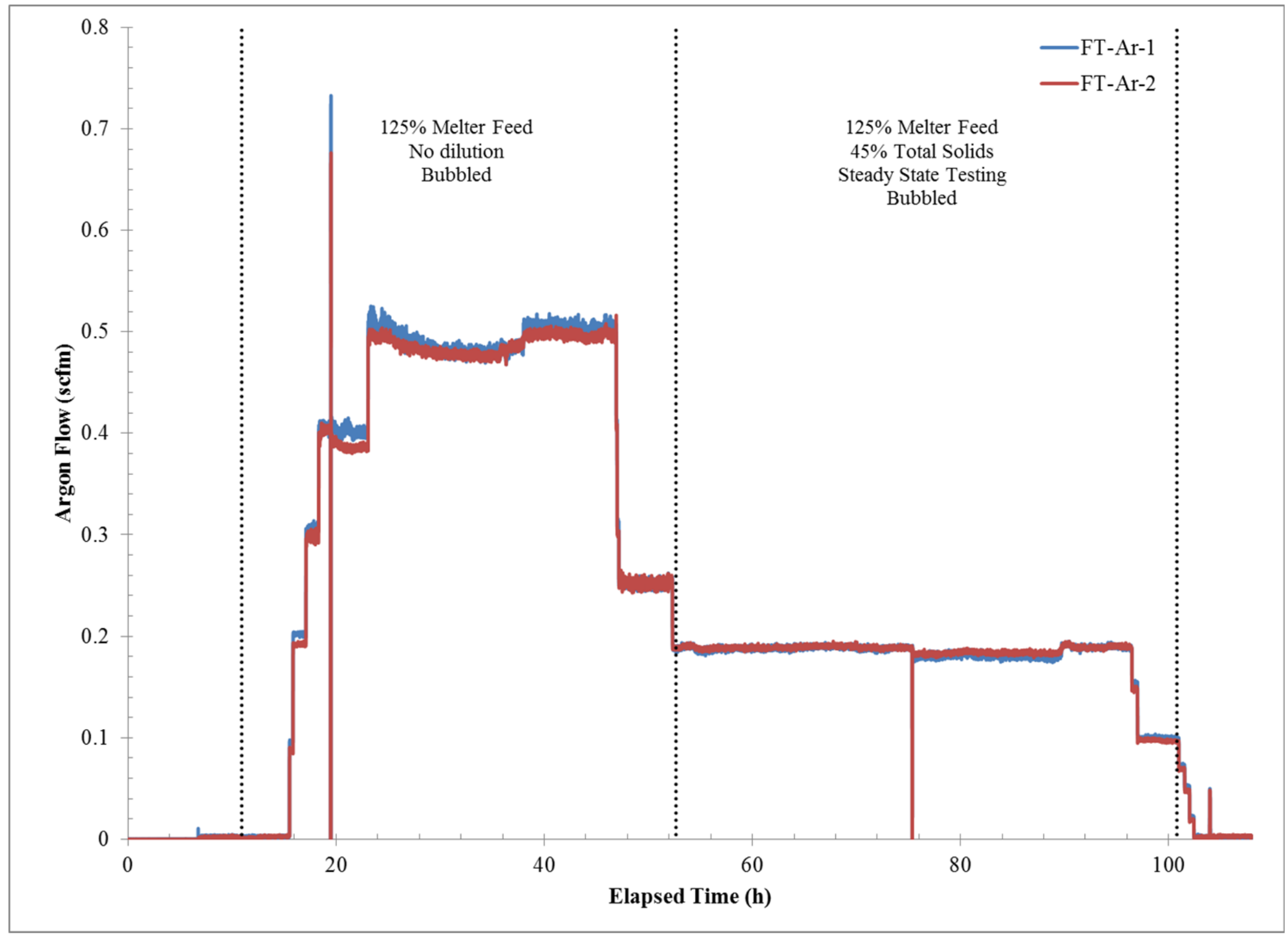

Figure A-16. Argon bubbler flows (elapsed time=0 at 12:00 February 24, 2014). 


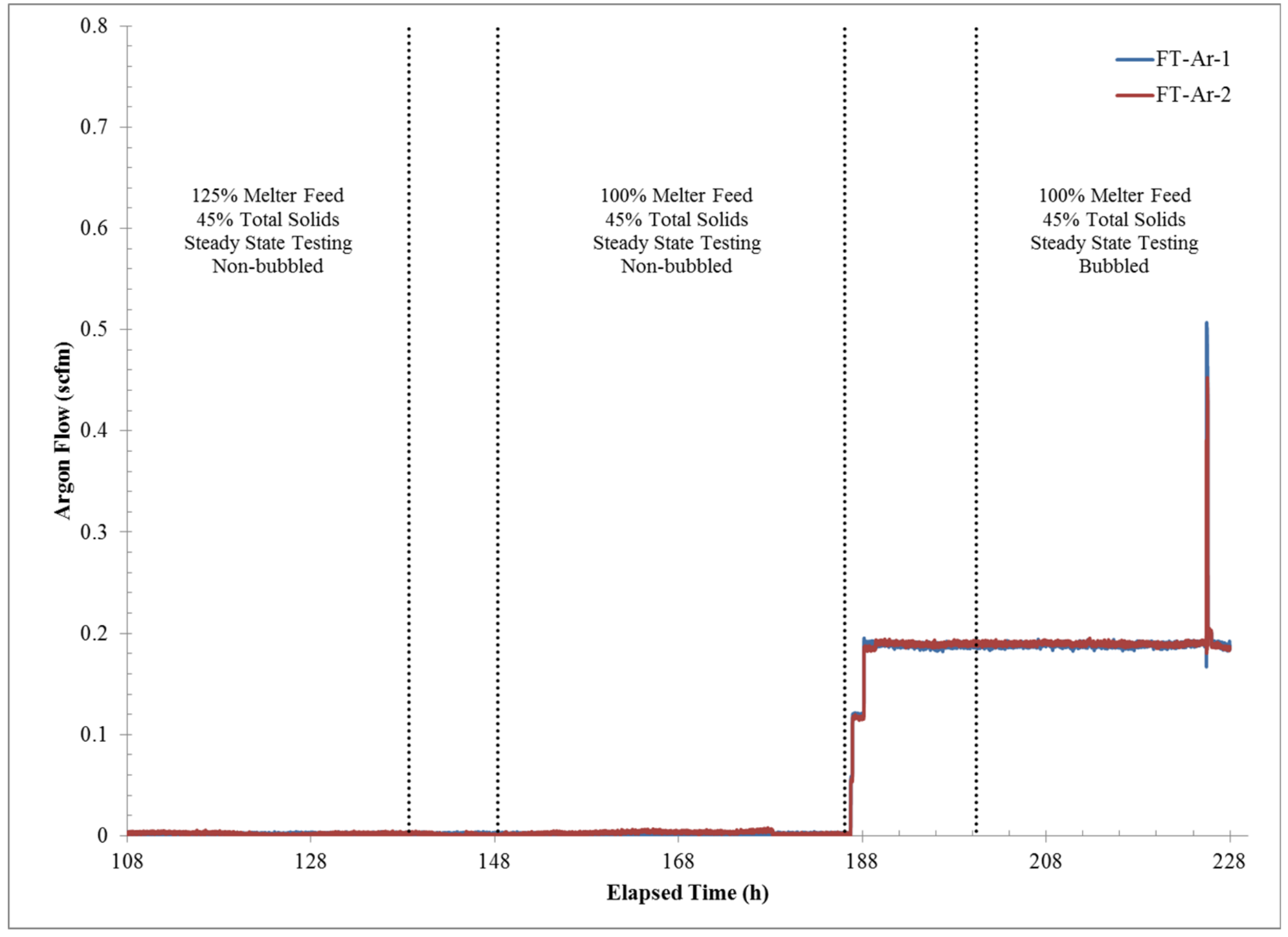

Figure A-17. Argon bubbler flows (elapsed time=108 at 00:00 March 1, 2014). 


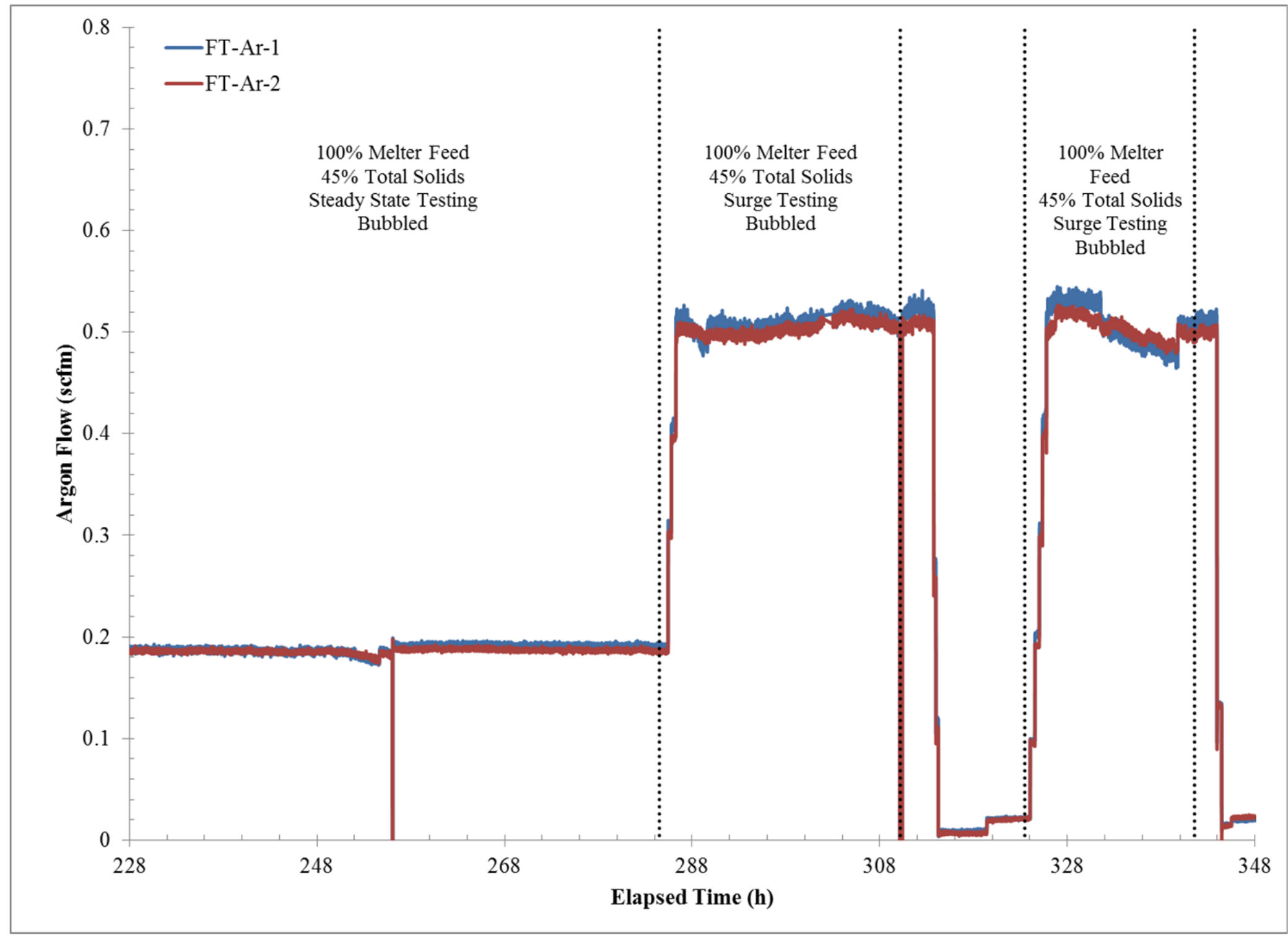

Figure A-18. Argon bubbler flows (elapsed time=228 at 00:00 March 6, 2014). 


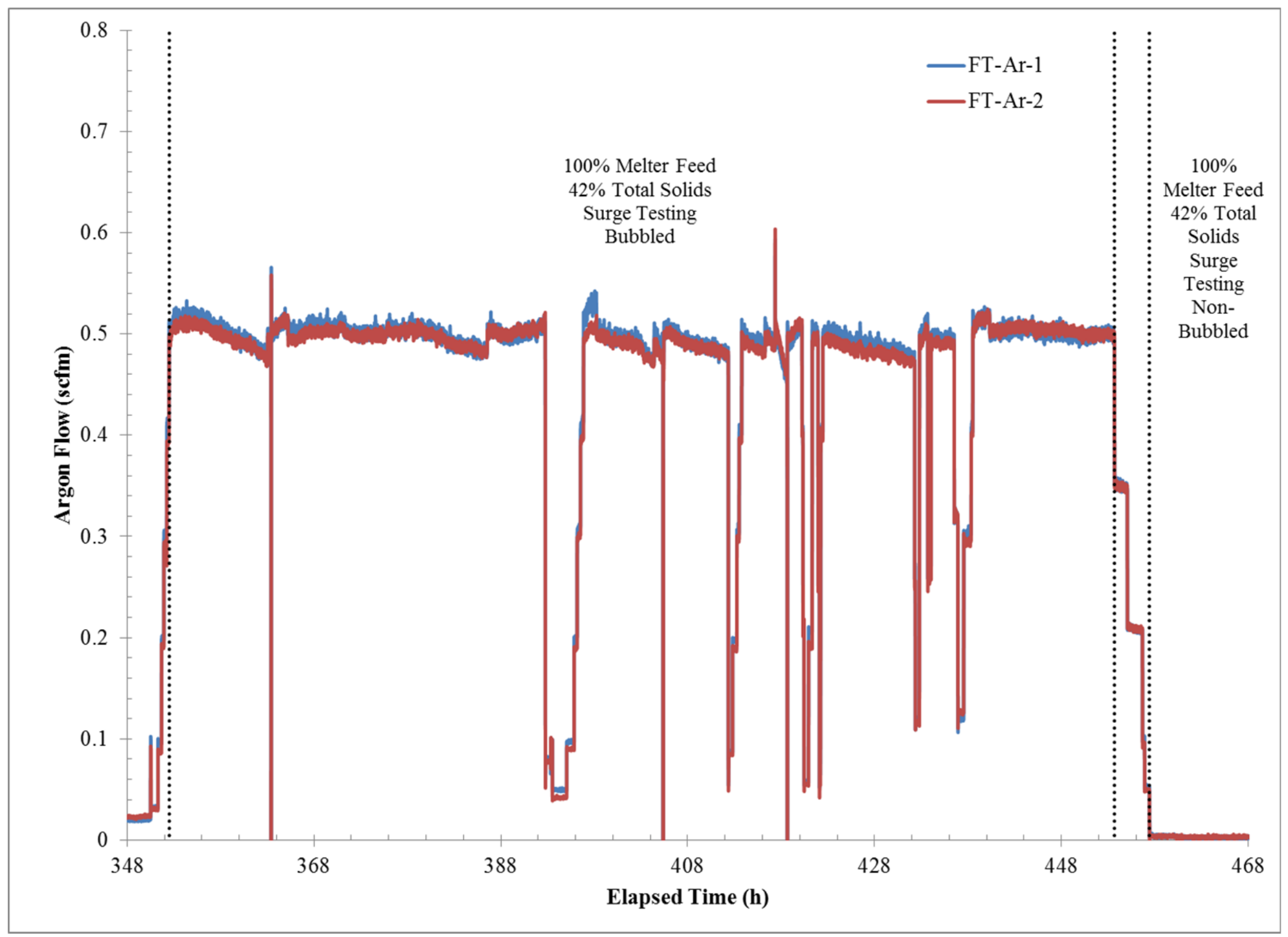

Figure A-19. Argon bubbler flows (elapsed time=348 at 00:00 March 11, 2014). 


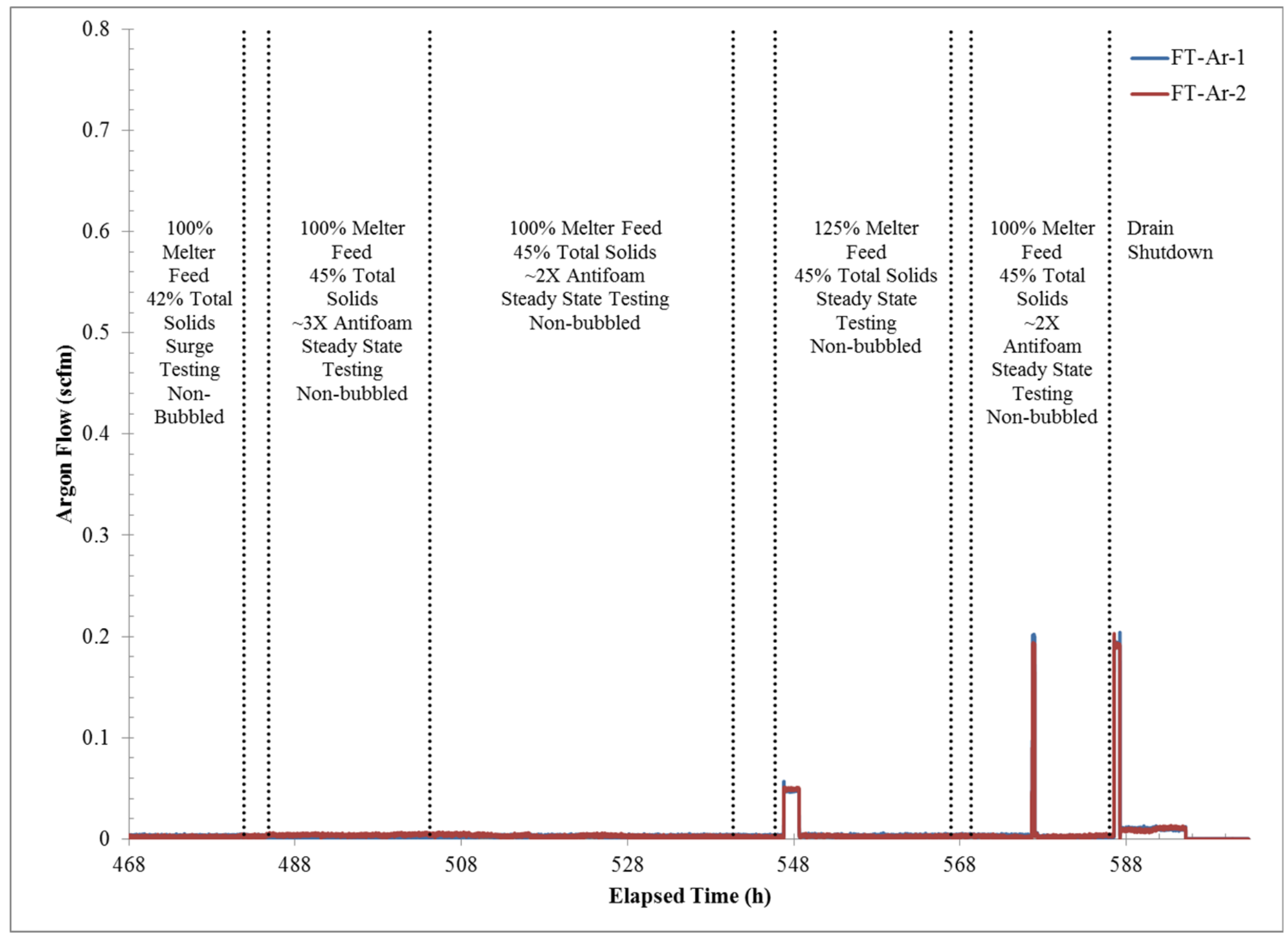

Figure A-20. Argon bubbler flows (elapsed time=468 at 00:00 March 16, 2014). 


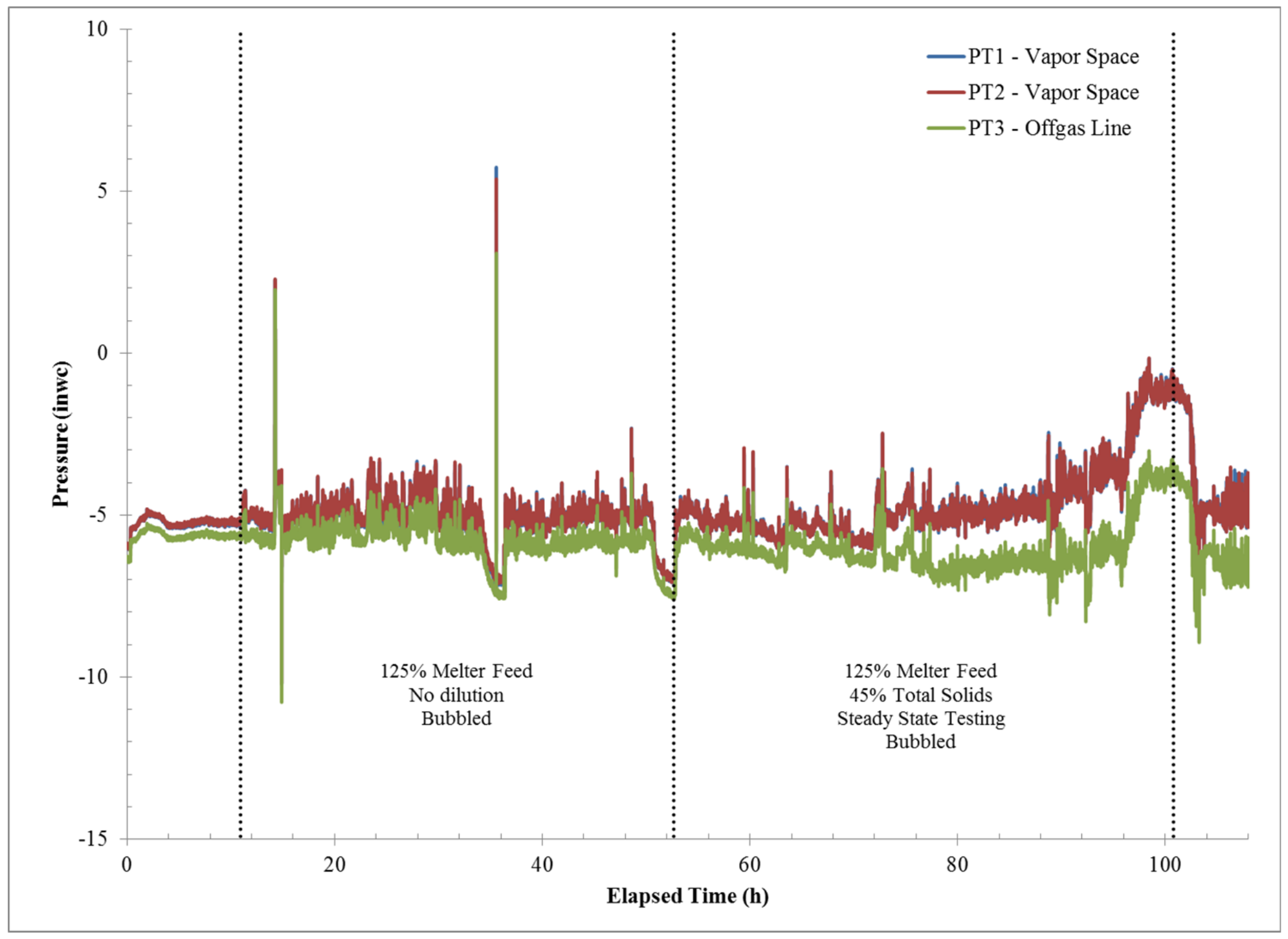

Figure A-21. Vapor space and off-gas line pressures (elapsed time=0 at 12:00 February 24, 2014). 


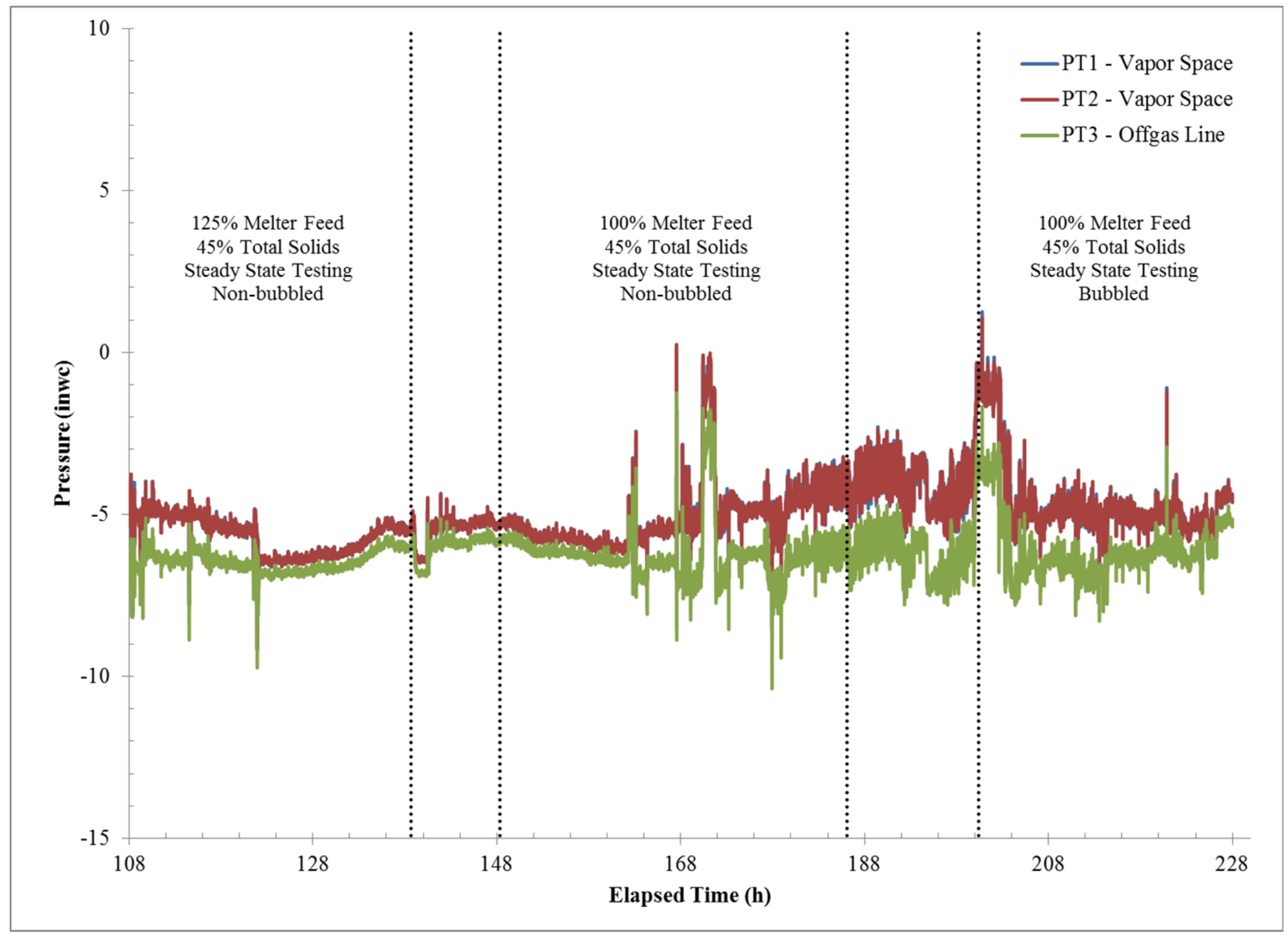

Figure A-22. Vapor space and off-gas line pressures (elapsed time=108 at 00:00 March 1, 2014). 


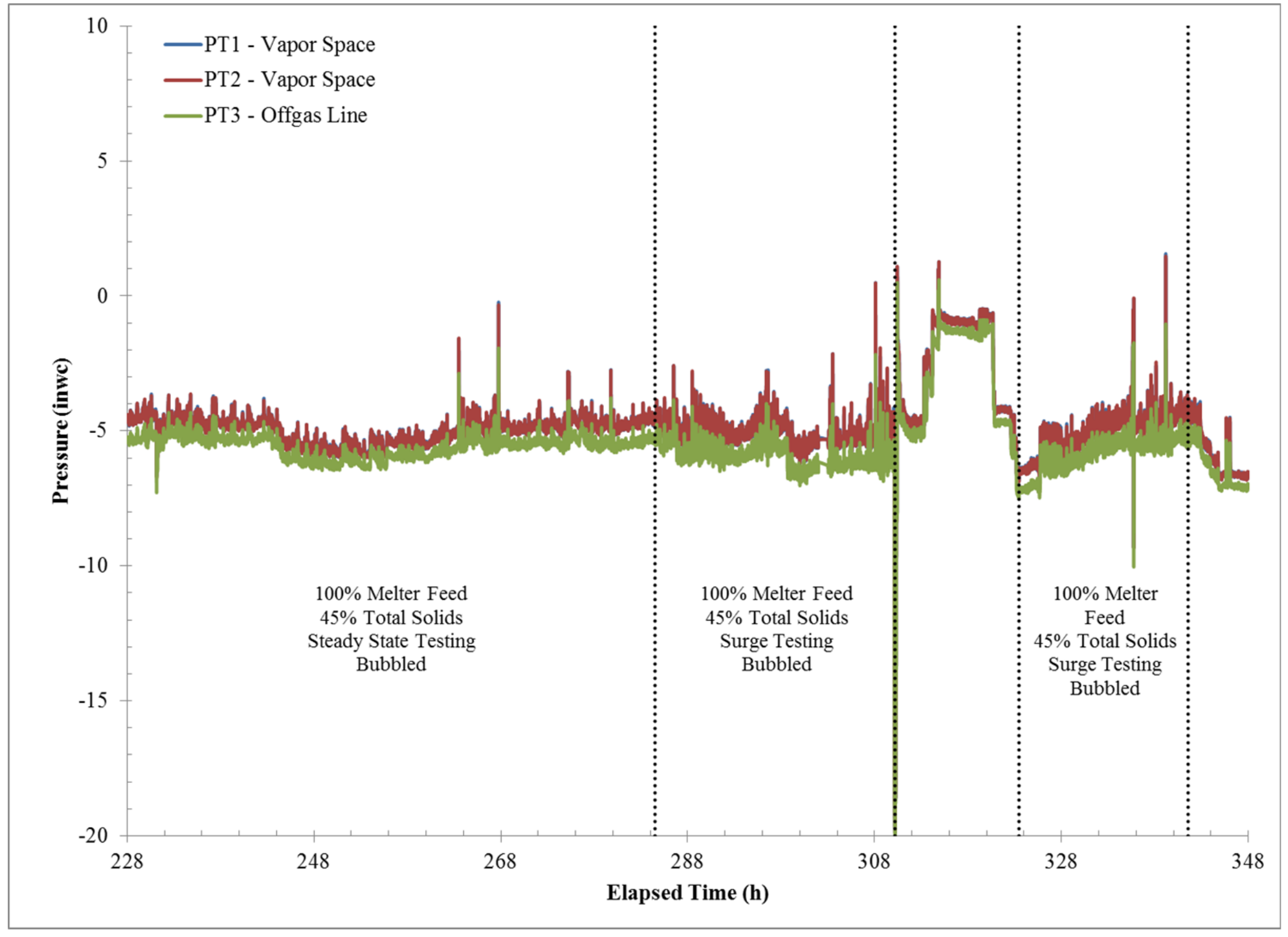

Figure A-23. Vapor space and off-gas line pressures (elapsed time=228 at 00:00 March 6, 2014). 


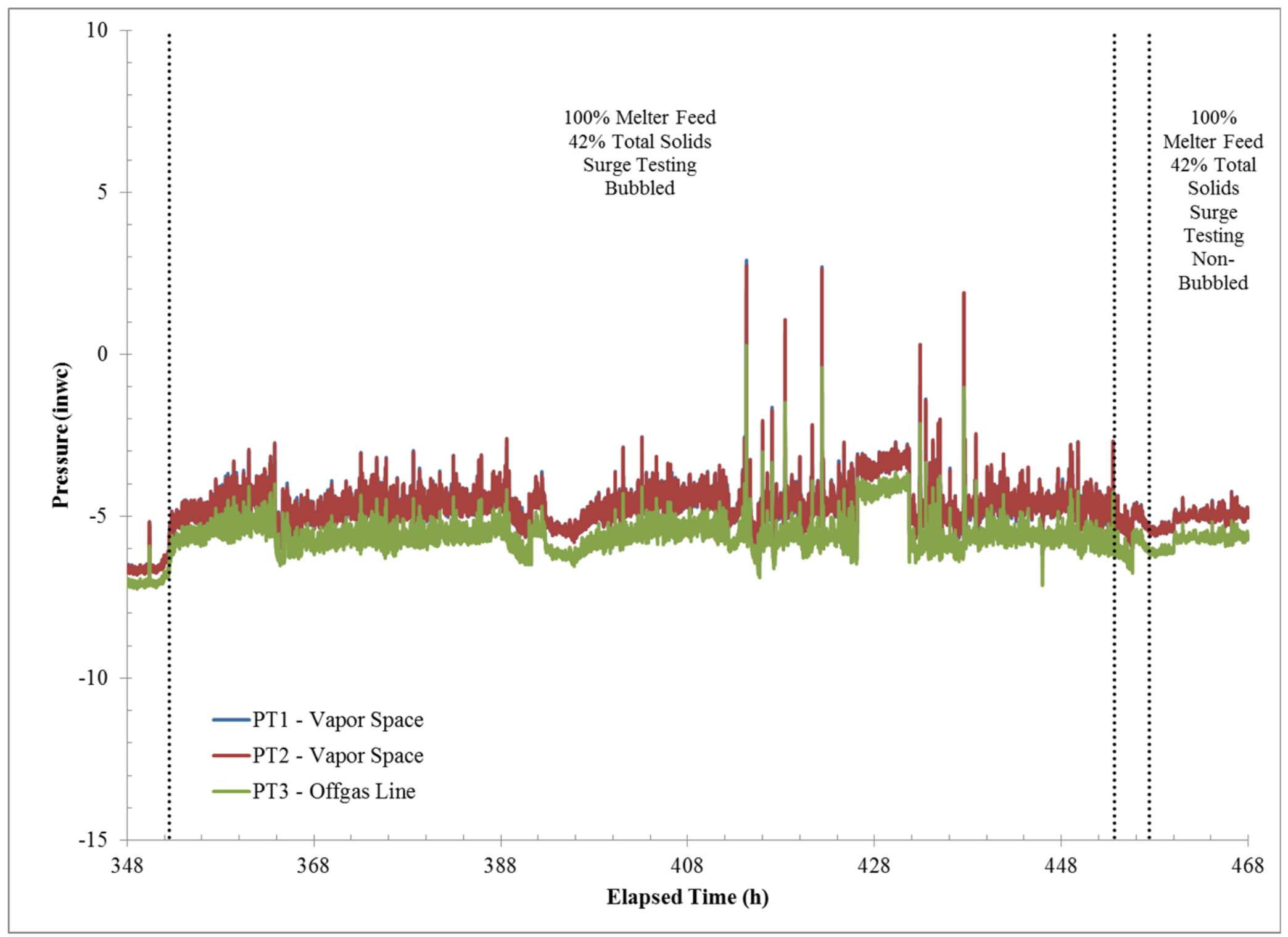

Figure A-24. Vapor space and off-gas line pressures (elapsed time=348 at 00:00 March 11, 2014). 


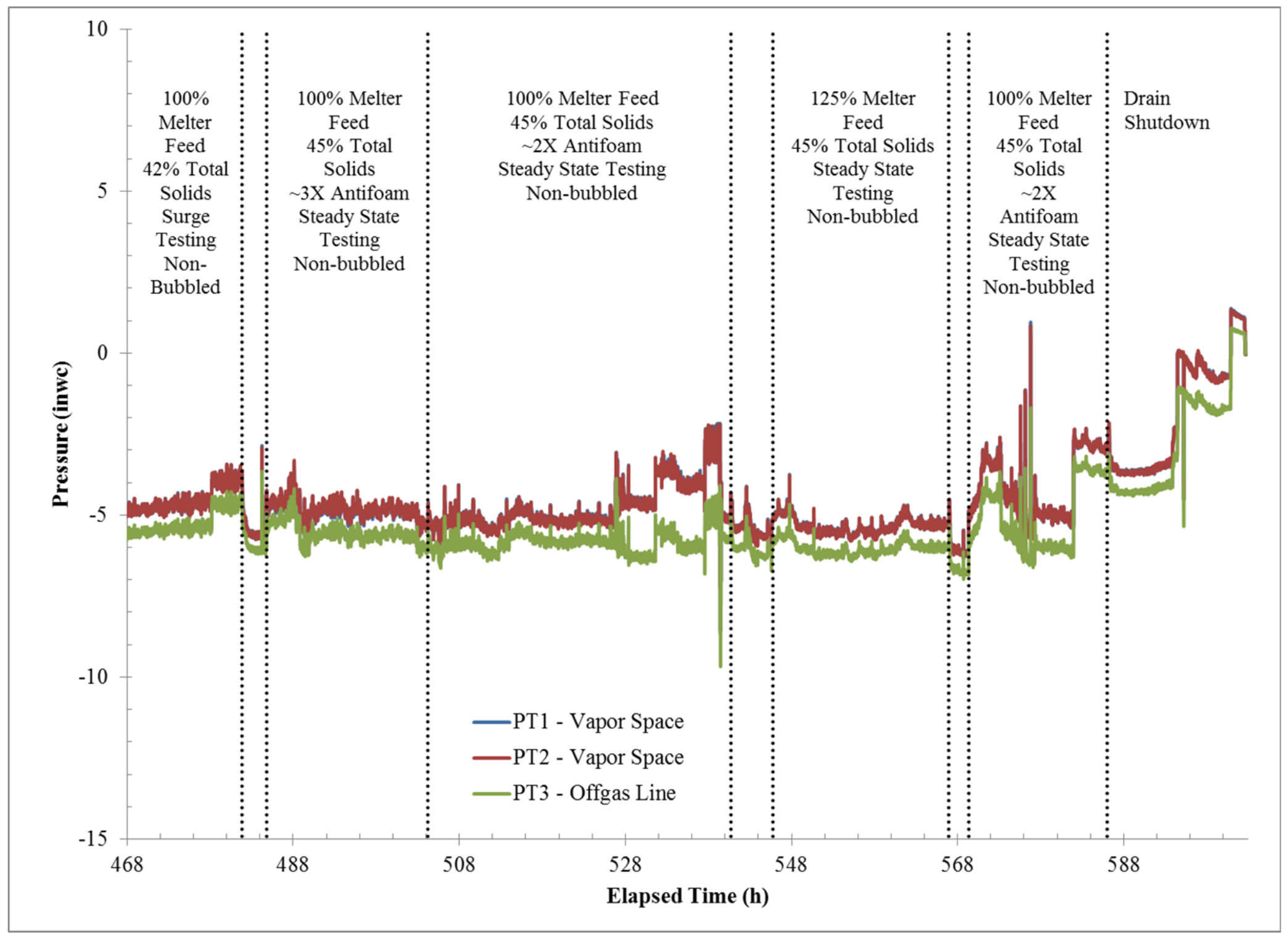

Figure A-25. Vapor space and off-gas line pressures (elapsed time=468 at 00:00 March 16, 2014). 


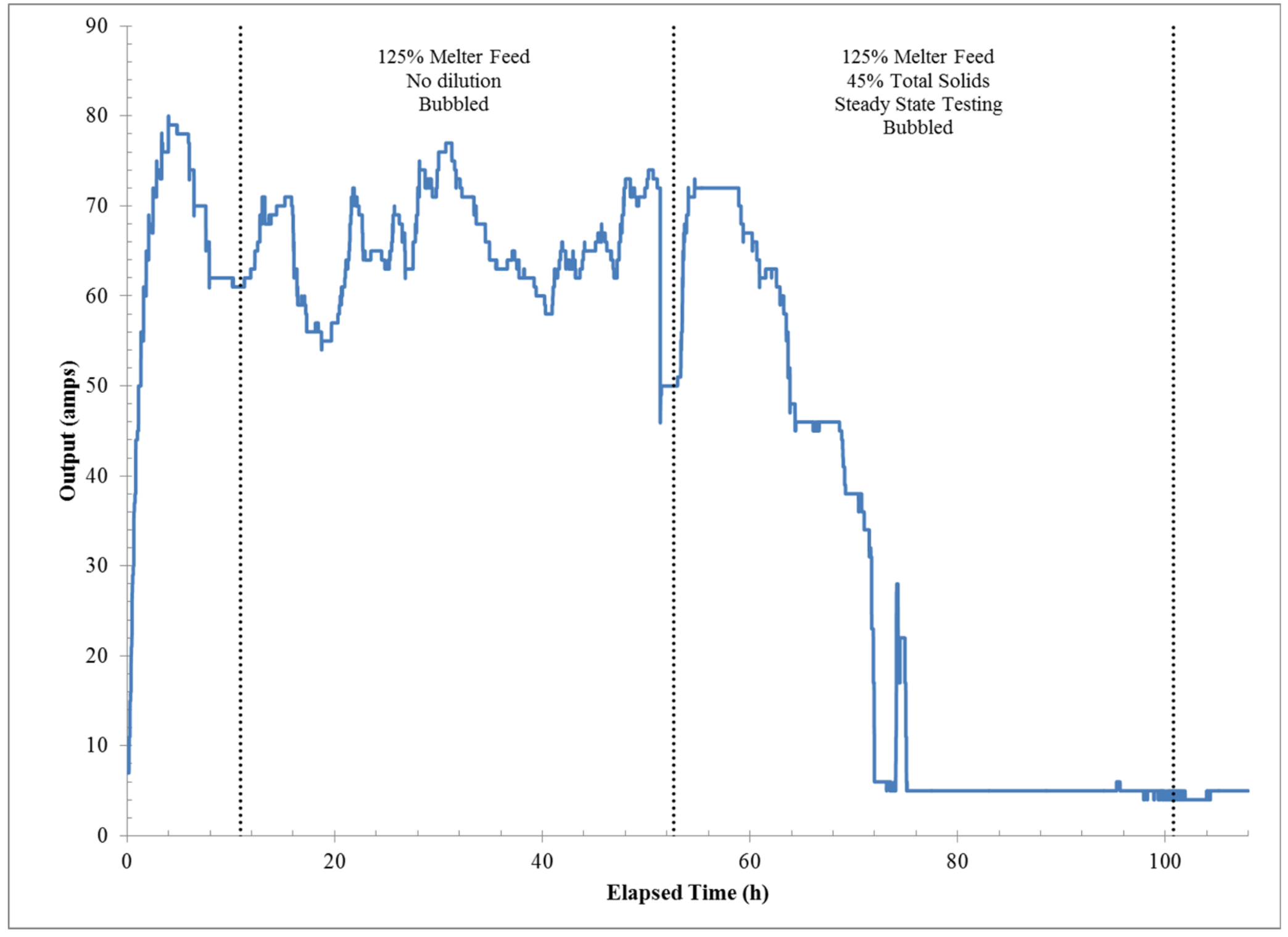

Figure A-26. Vapor space heater output (elapsed time=0 at 12:00 February 24, 2014). 


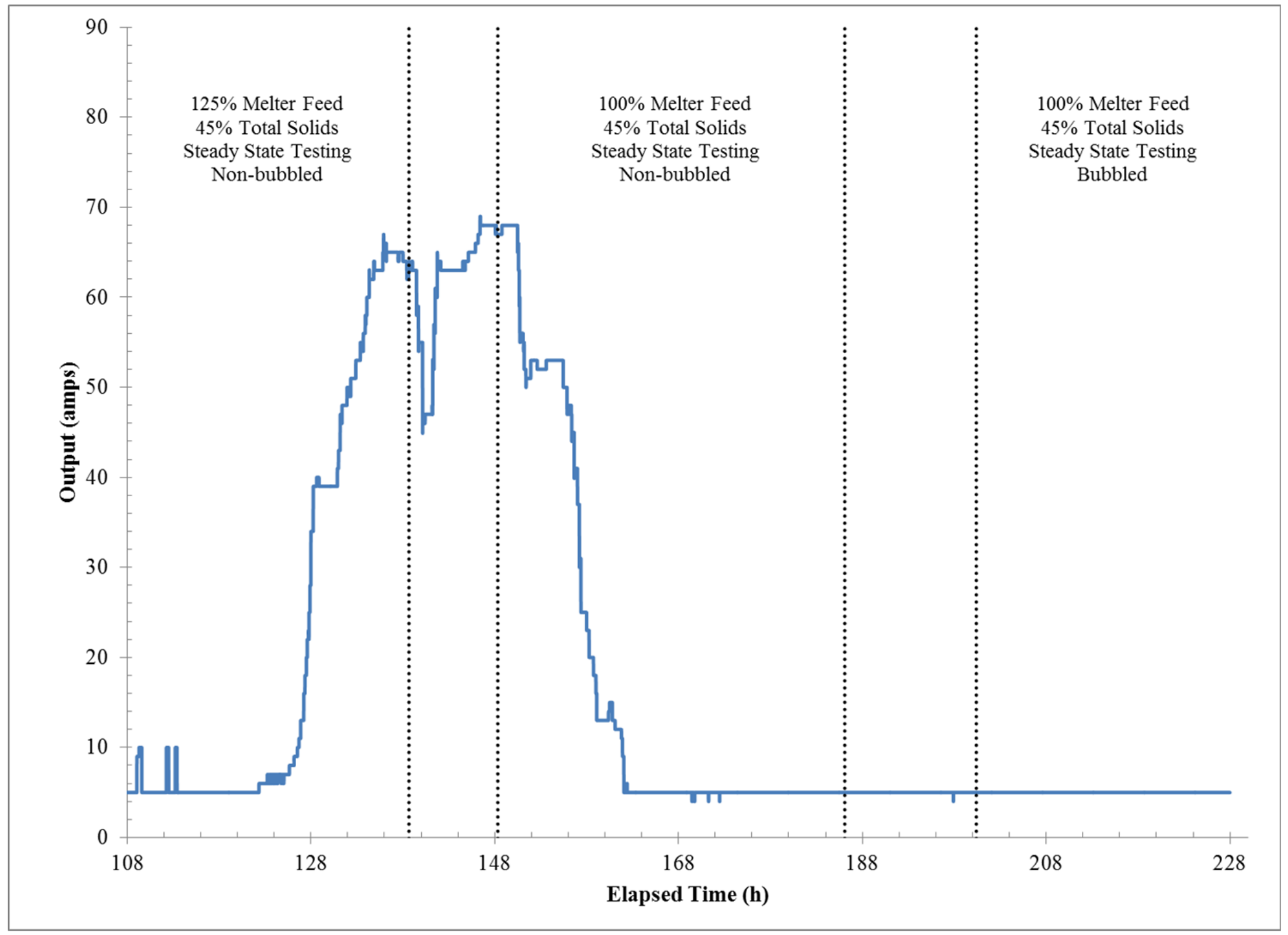

Figure A-27. Vapor space heater output (elapsed time=108 at 00:00 March 1, 2014). 


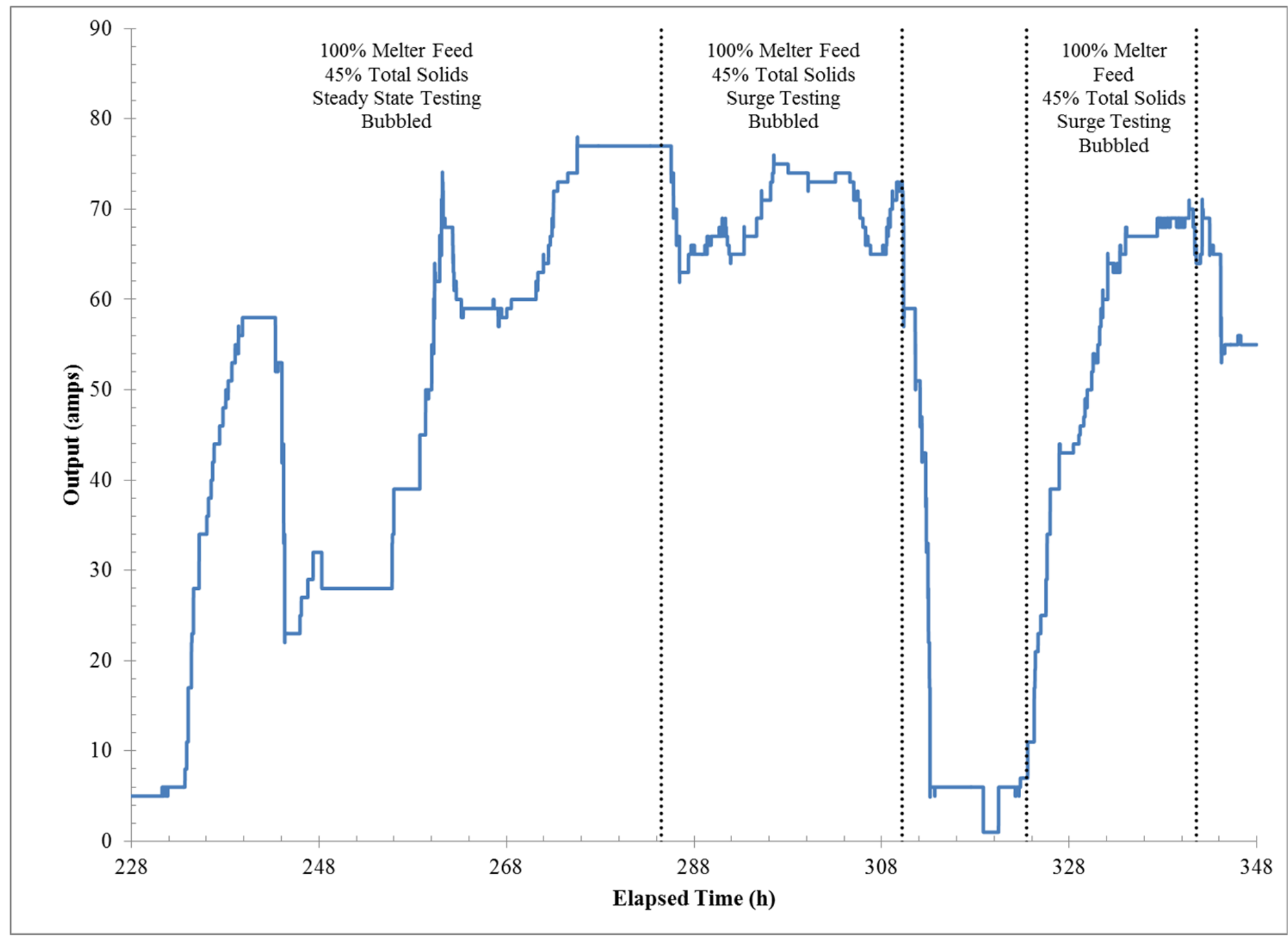

Figure A-28. Vapor space heater output (elapsed time=228 at 00:00 March 6, 2014). 


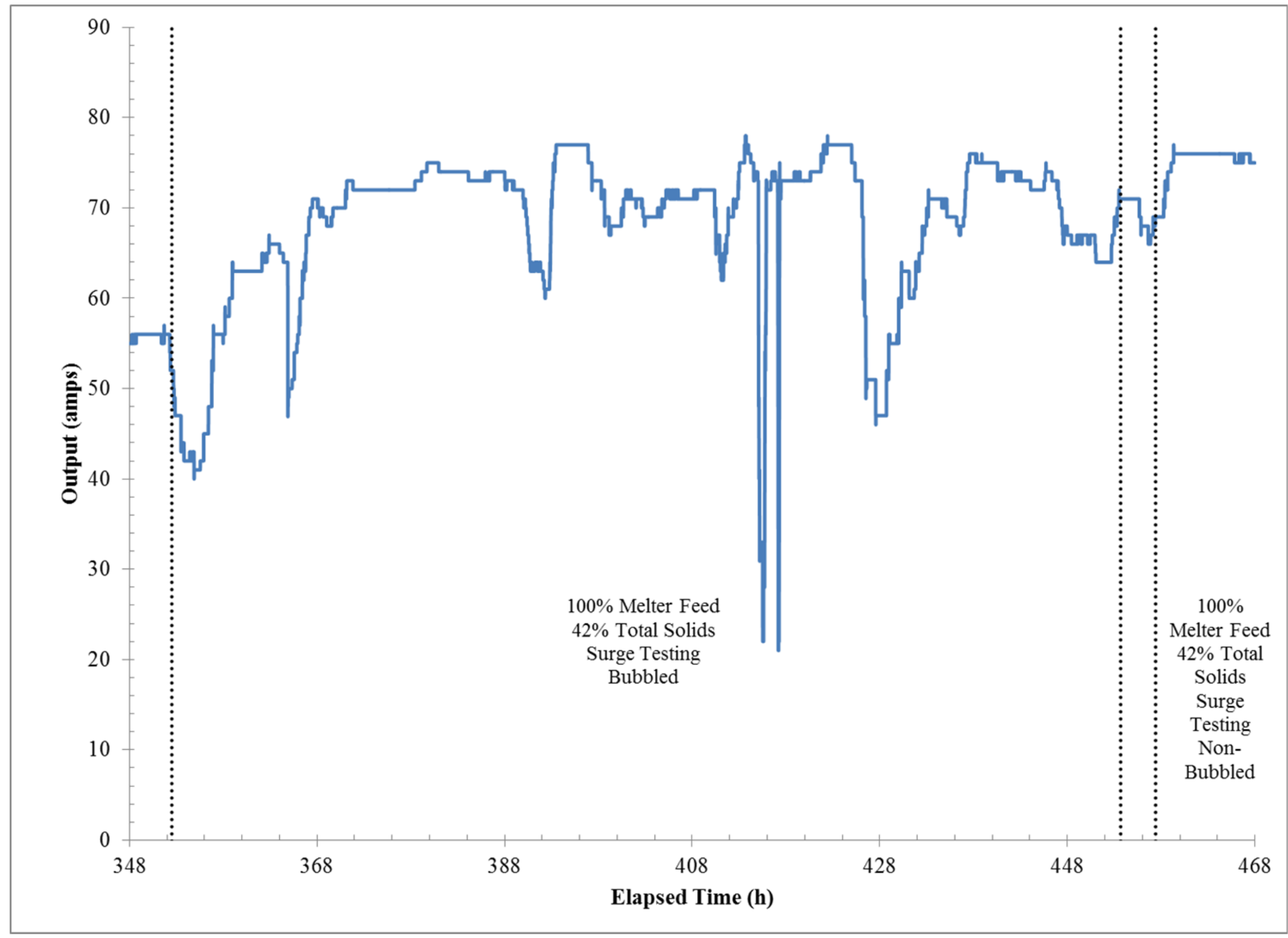

Figure A-29. Vapor space heater output (elapsed time=348 at 00:00 March 11, 2014). 


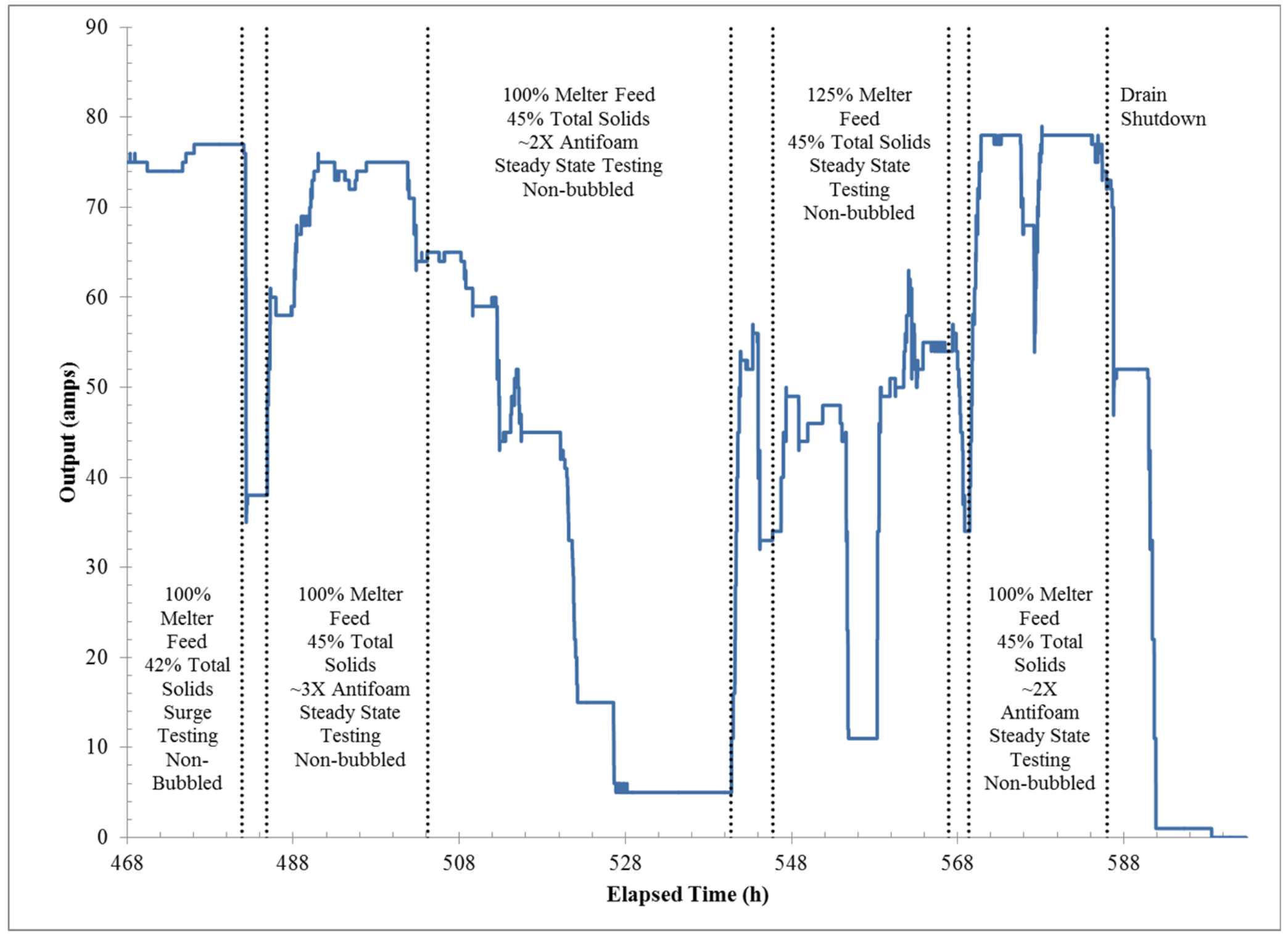

Figure A-30. Vapor space heater output (elapsed time=468 at 00:00 March 16, 2014). 


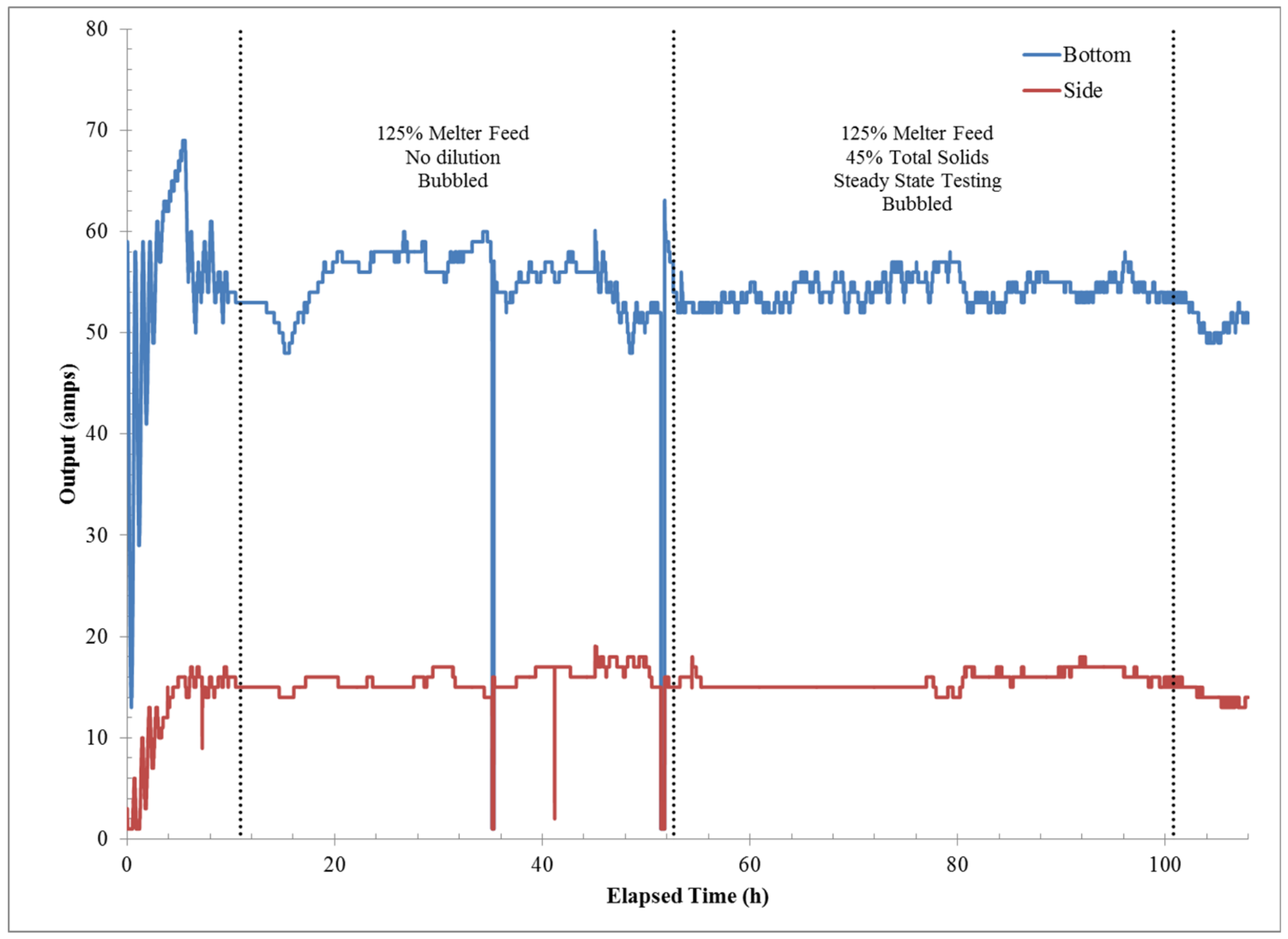

Figure A-31. Bottom and side heater outputs (elapsed time=0 at 12:00 February 24, 2014). 


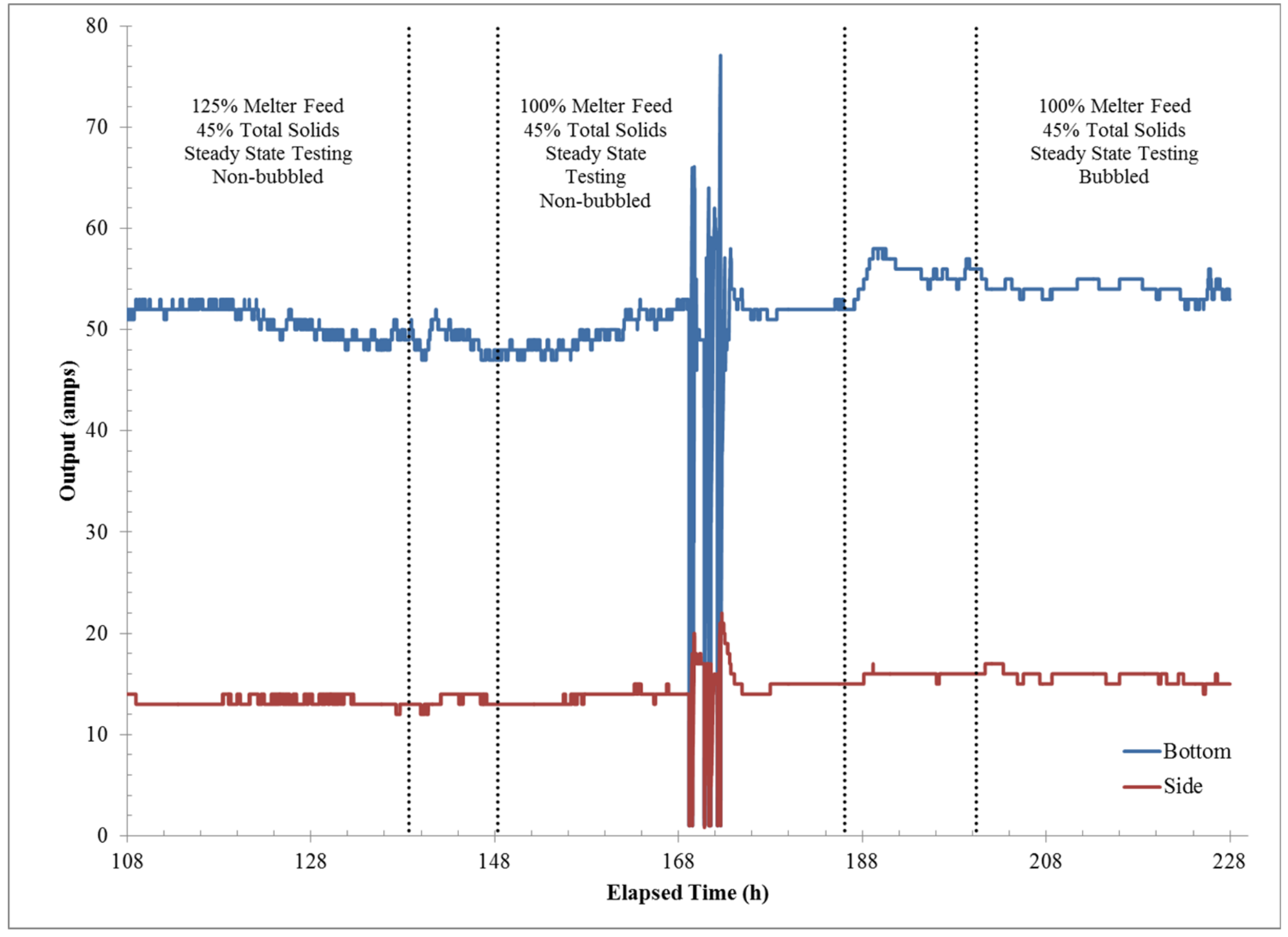

Figure A-32. Bottom and side heater outputs (elapsed time=108 at 00:00 March 1, 2014). 


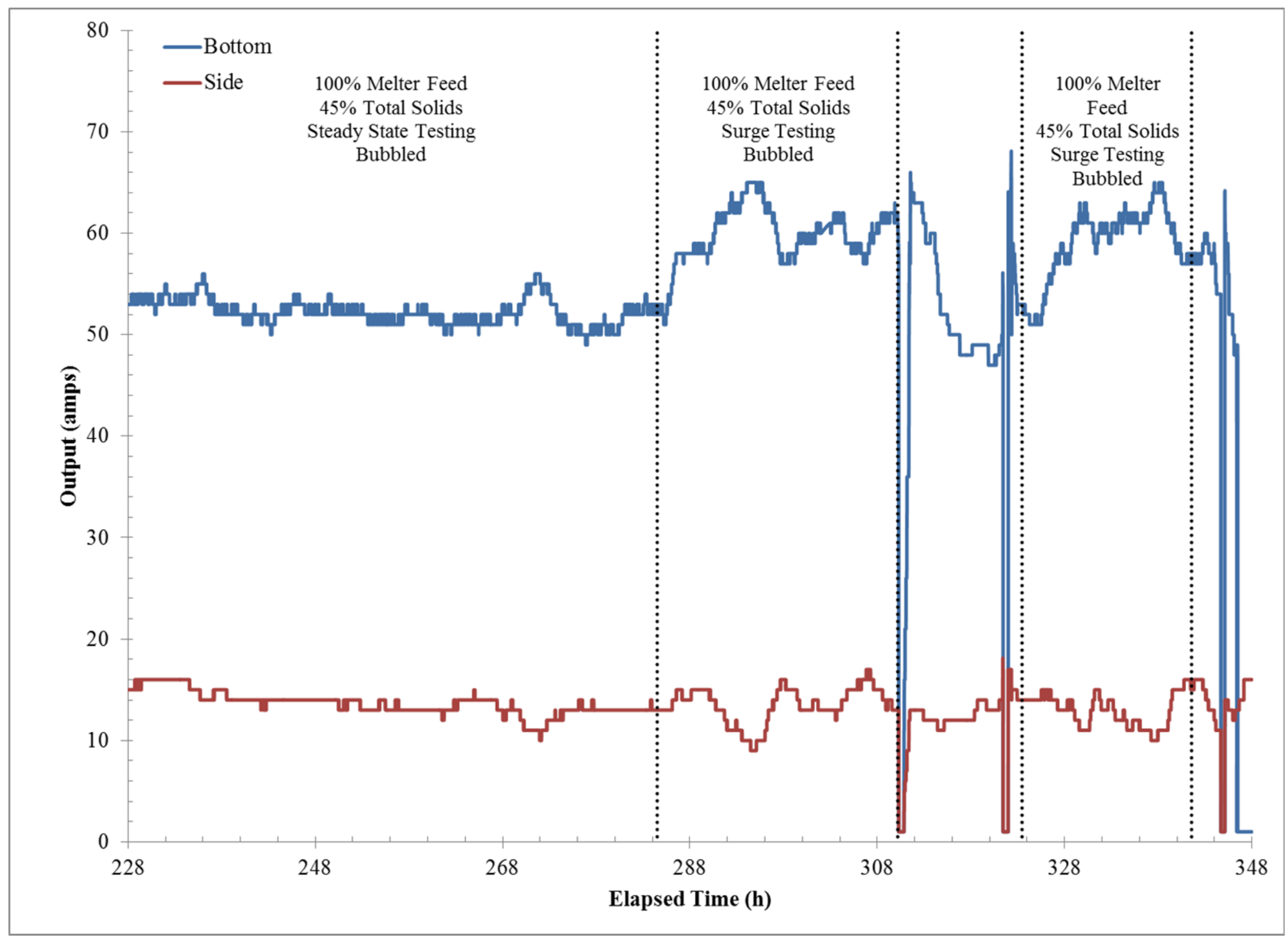

Figure A-33. Bottom and side heater outputs (elapsed time=228 at 00:00 March 6, 2014). 


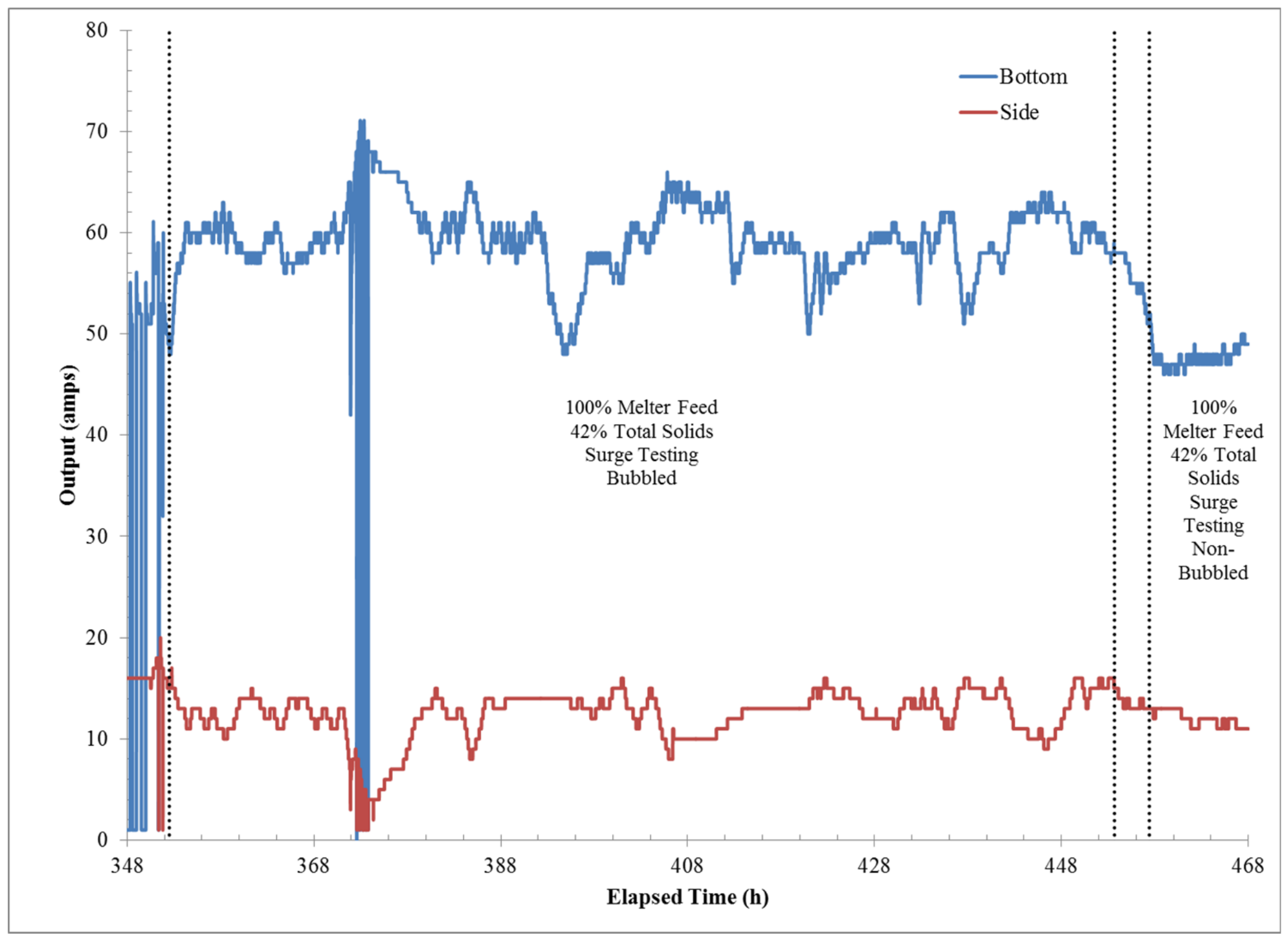

Figure A-34. Bottom and side heater outputs (elapsed time=348 at 00:00 March 11, 2014). 


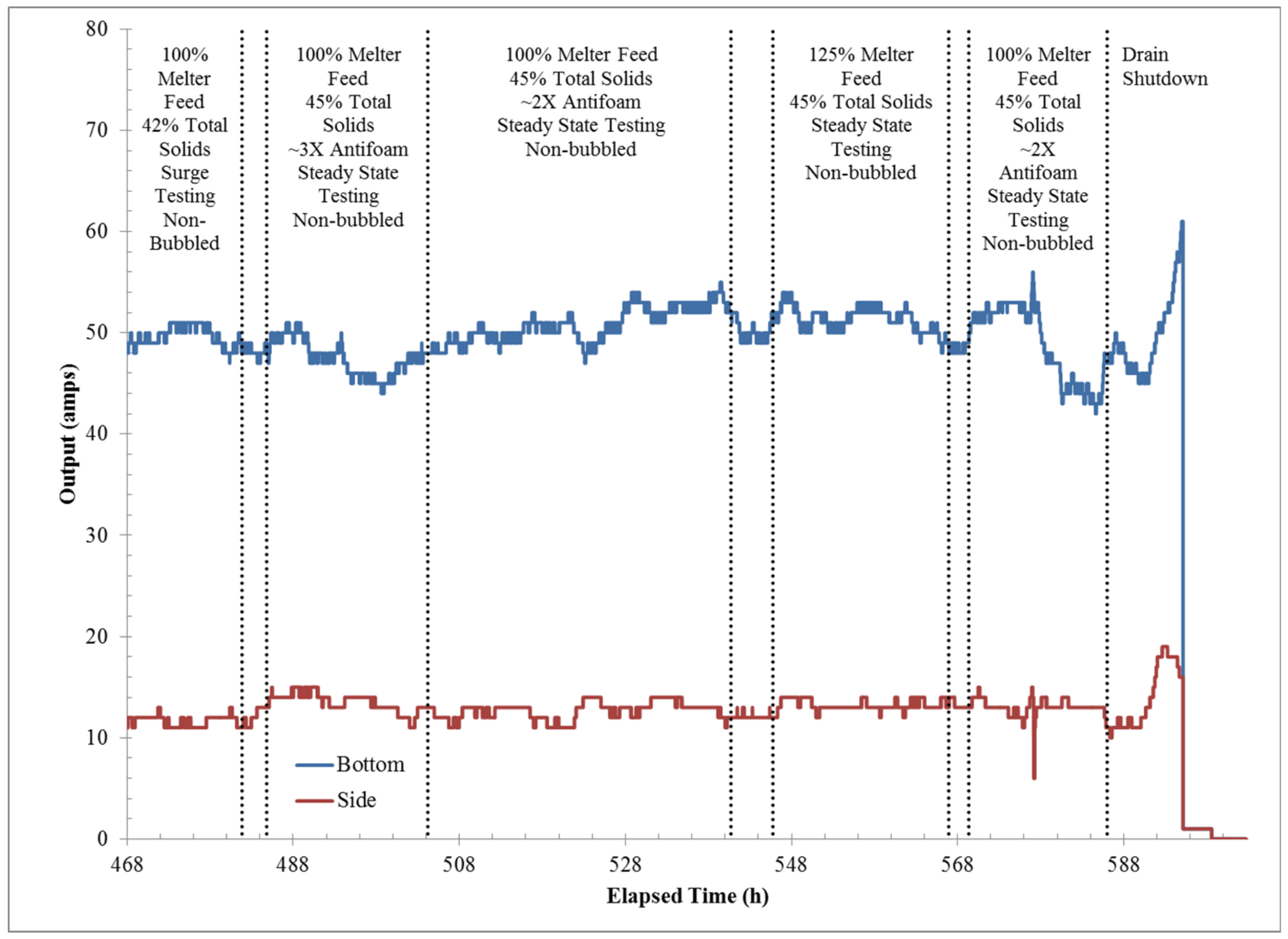

Figure A-35. Bottom and side heater outputs (elapsed time=468 at 00:00 March 16, 2014). 


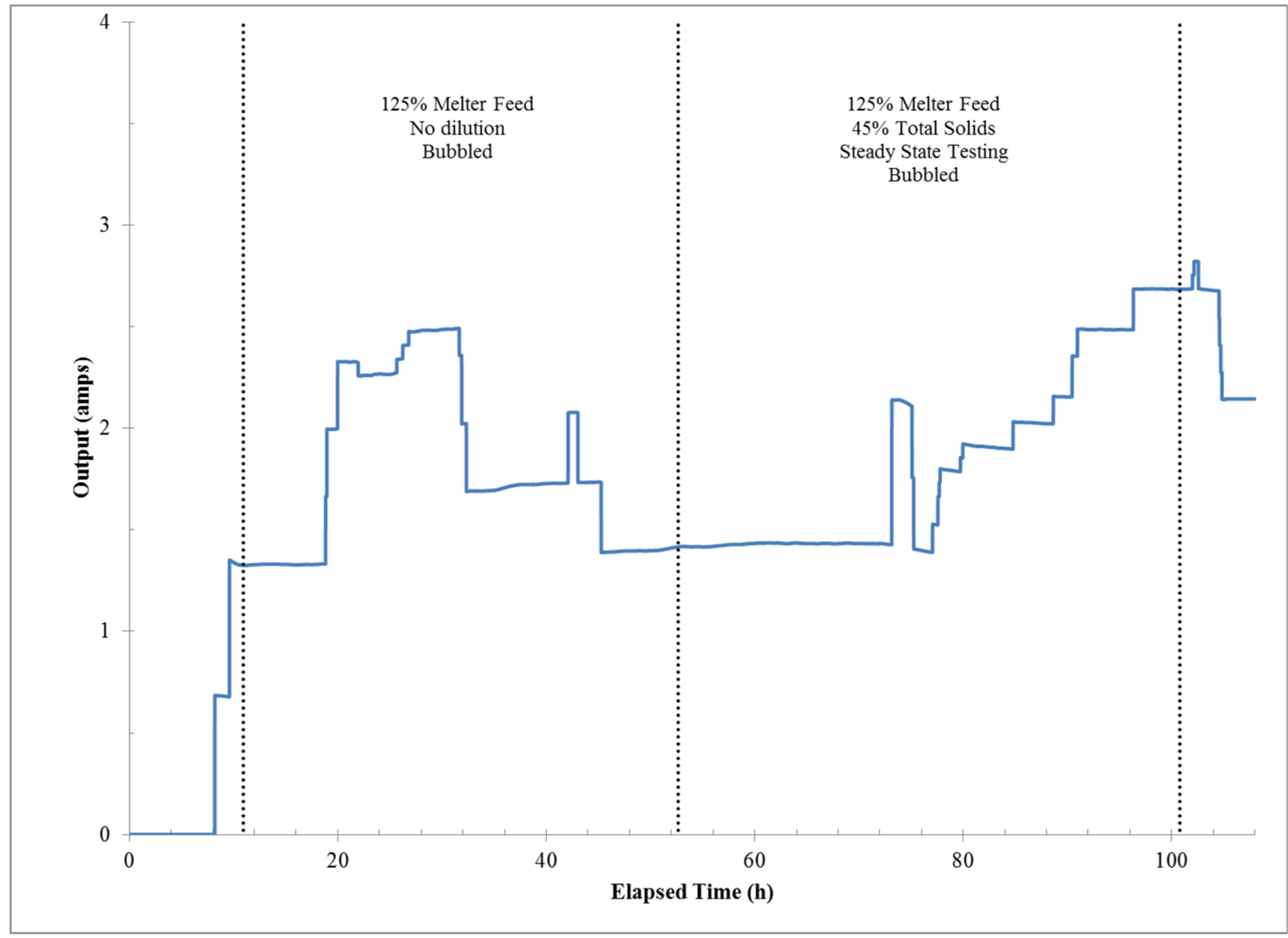

Figure A-36. Auxiliary pour tube rod heater output (elapsed time=0 at 12:00 February 24, 2014). 


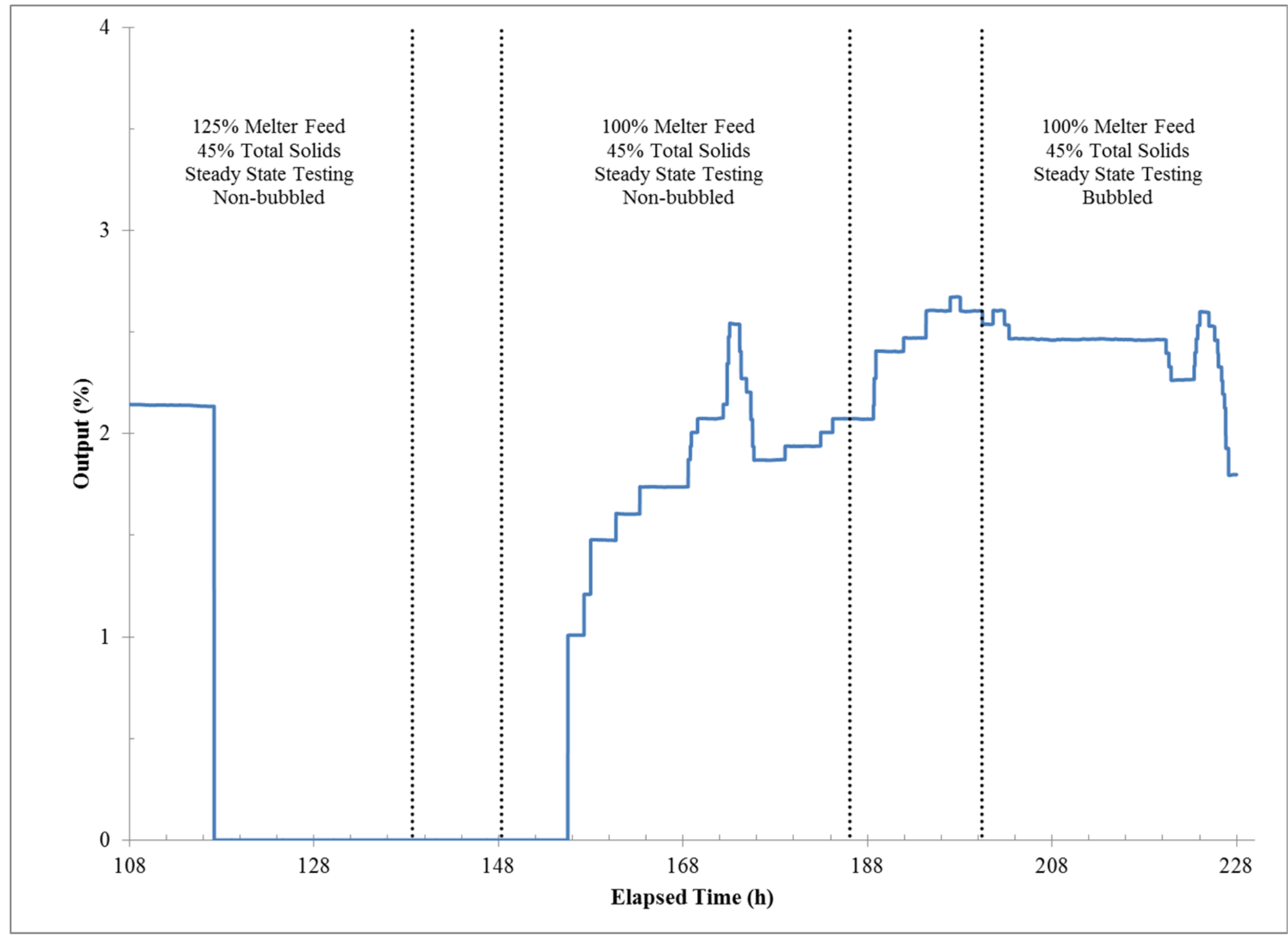

Figure A-37. Auxiliary pour tube rod heater output (elapsed time=108 at 00:00 March 1, 2014). 


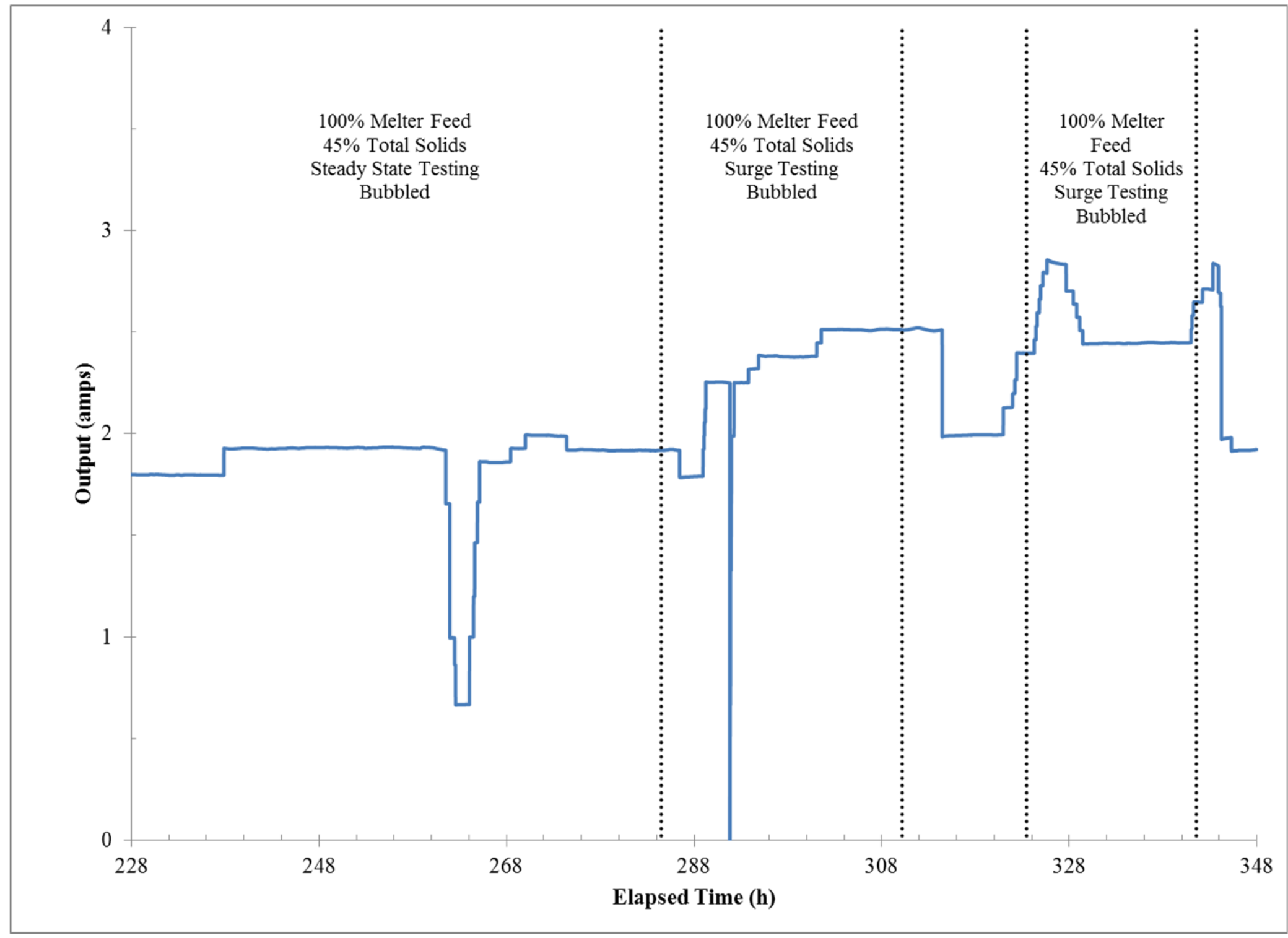

Figure A-38. Auxiliary pour tube rod heater output (elapsed time=228 at 00:00 March 6, 2014). 


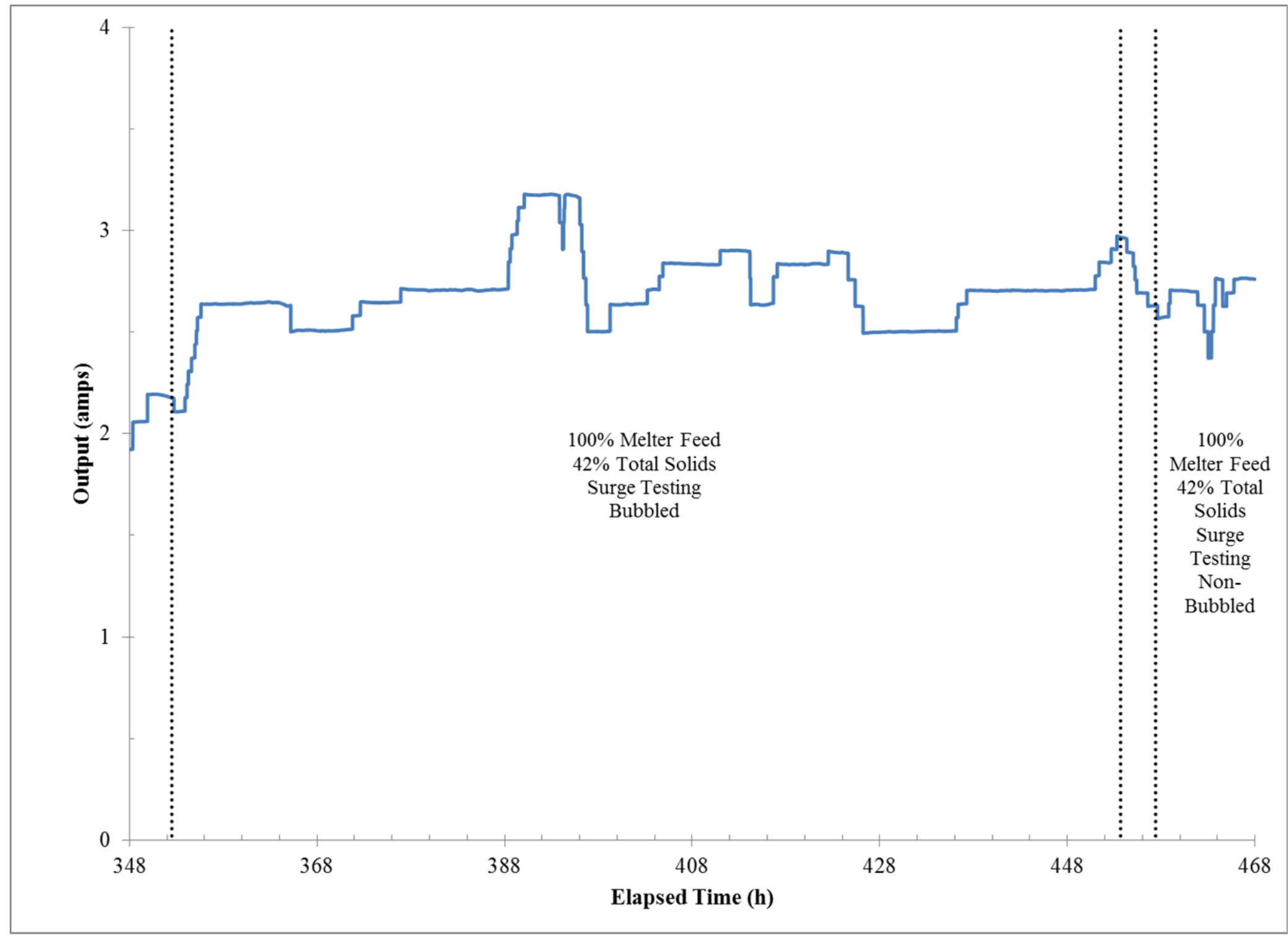

Figure A-39. Auxiliary pour tube rod heater output (elapsed time=348 at 00:00 March 11, 2014). 


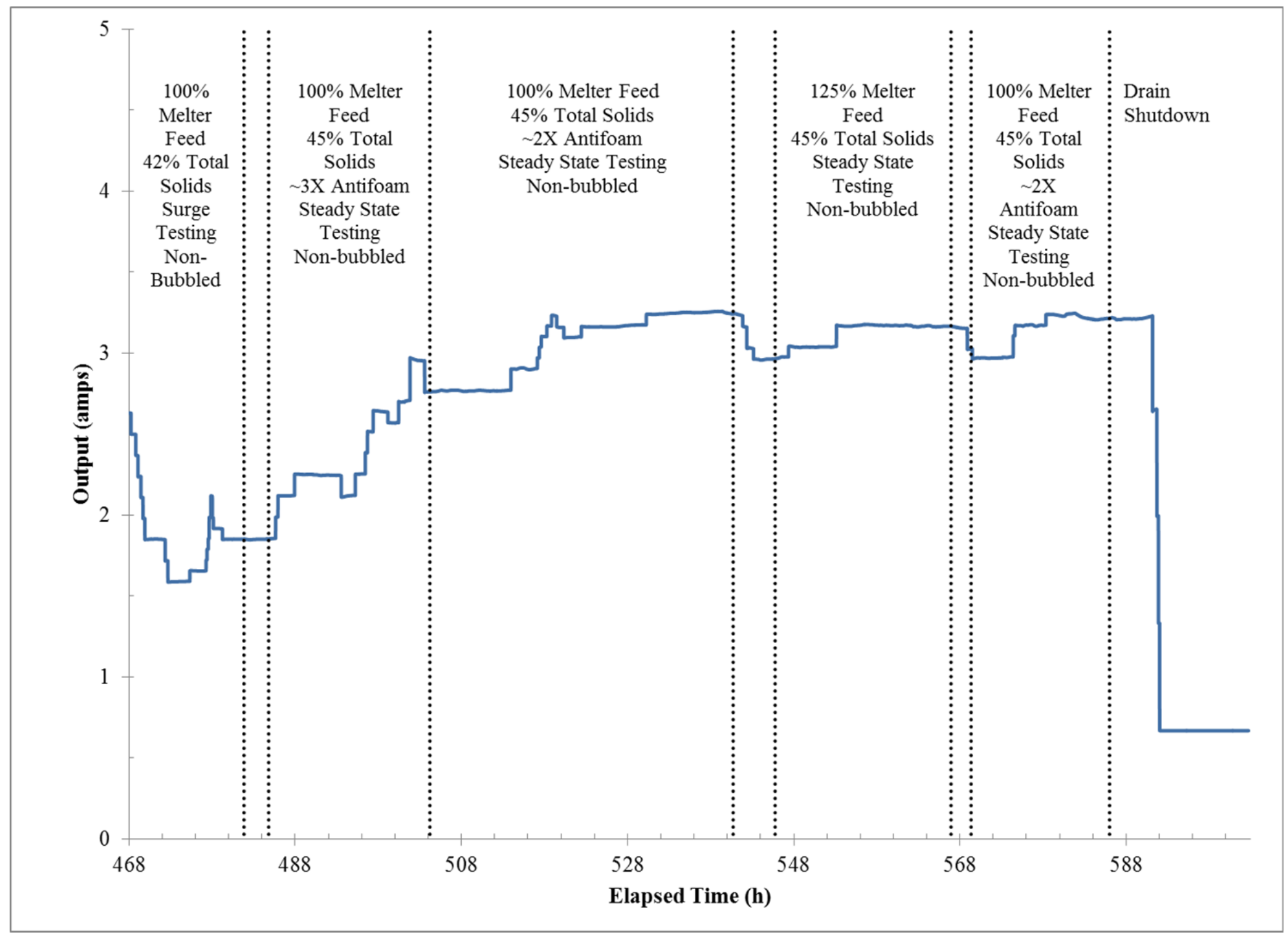

Figure A-40. Auxiliary pour tube rod heater output (elapsed time=468 at 00:00 March 16, 2014). 


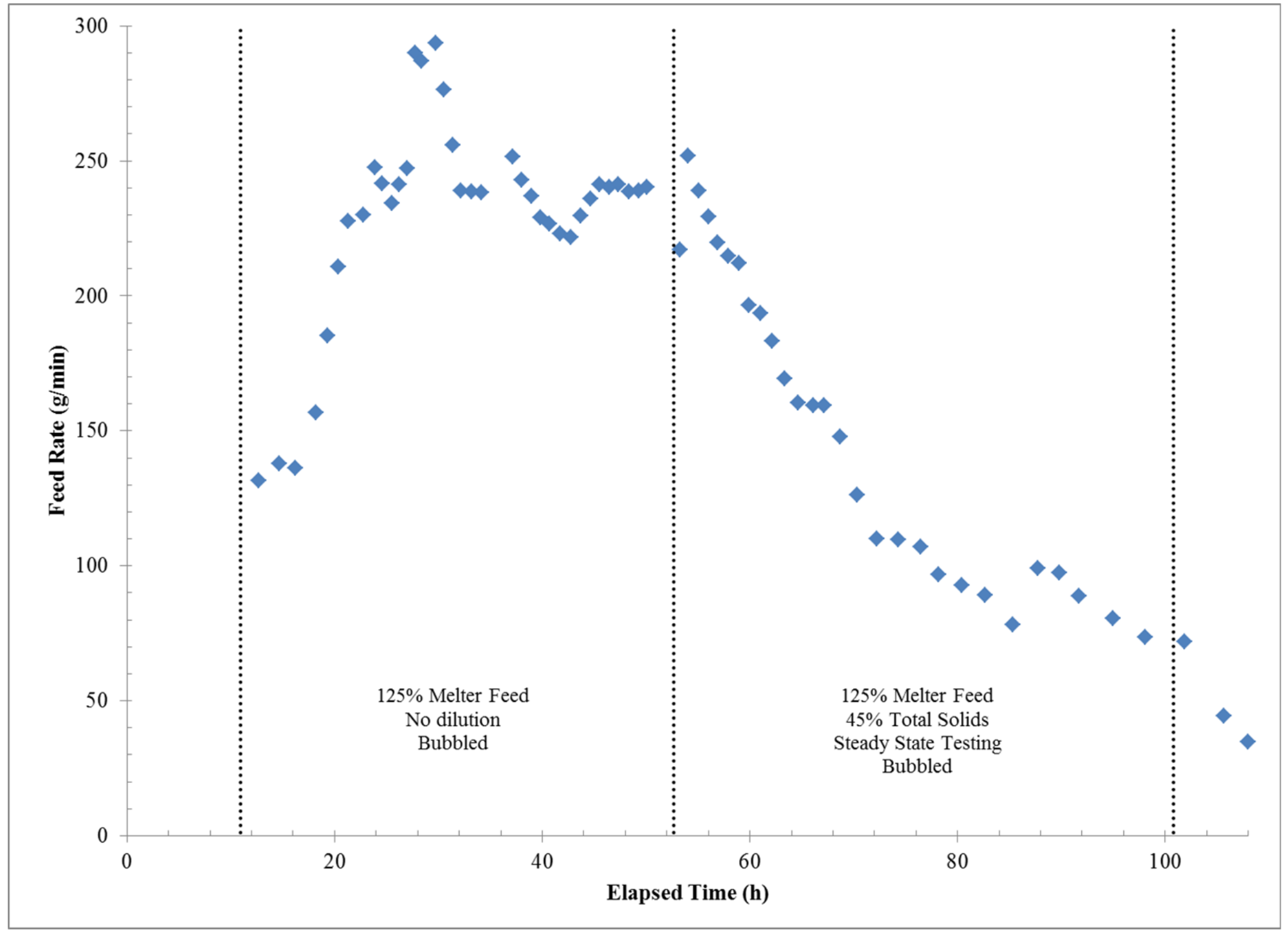

Figure A-41. Feed rate (elapsed time=0 at 12:00 February 24, 2014). 


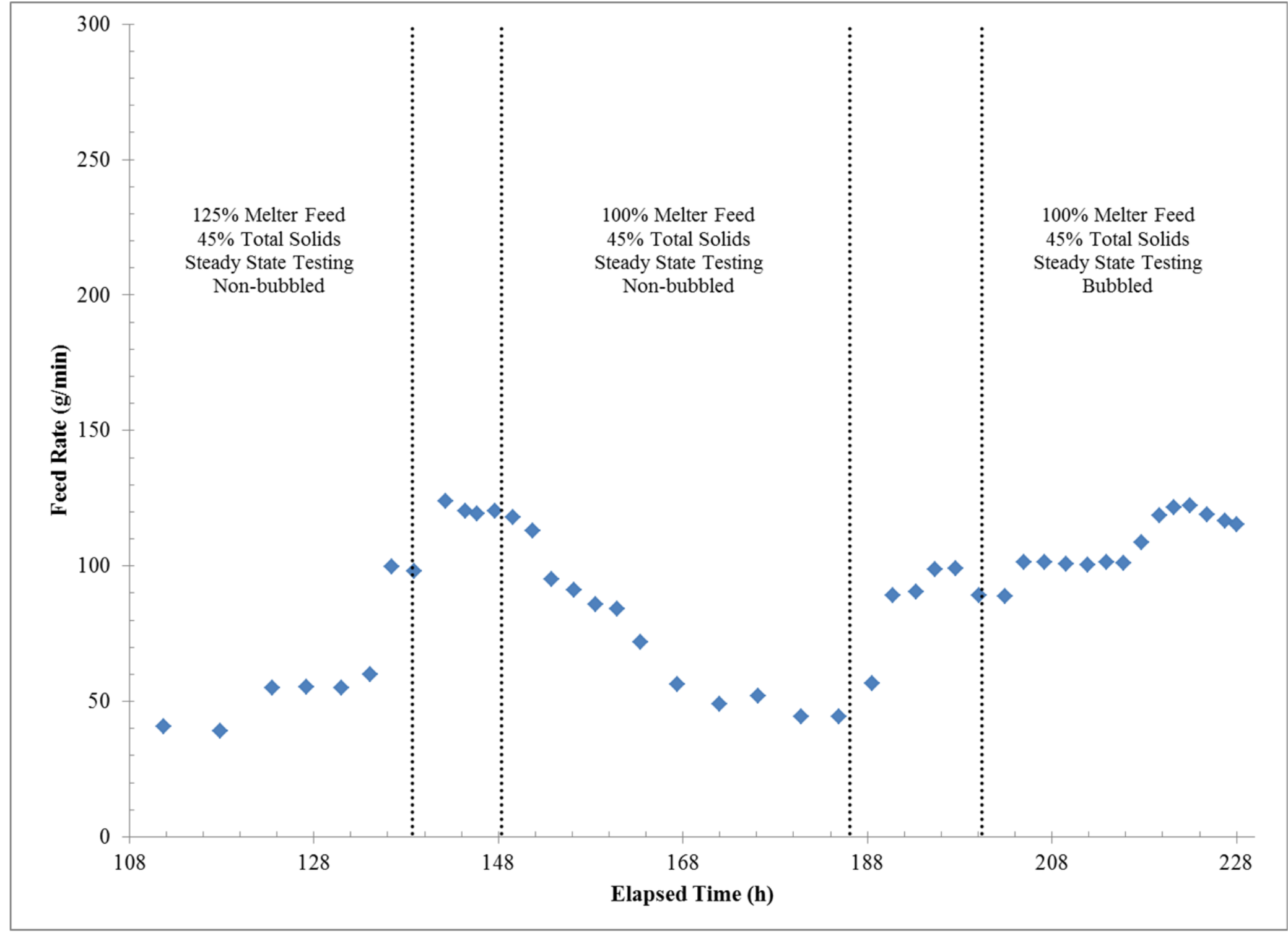

Figure A-42. Feed rate (elapsed time=108 at 00:00 March 1, 2014). 


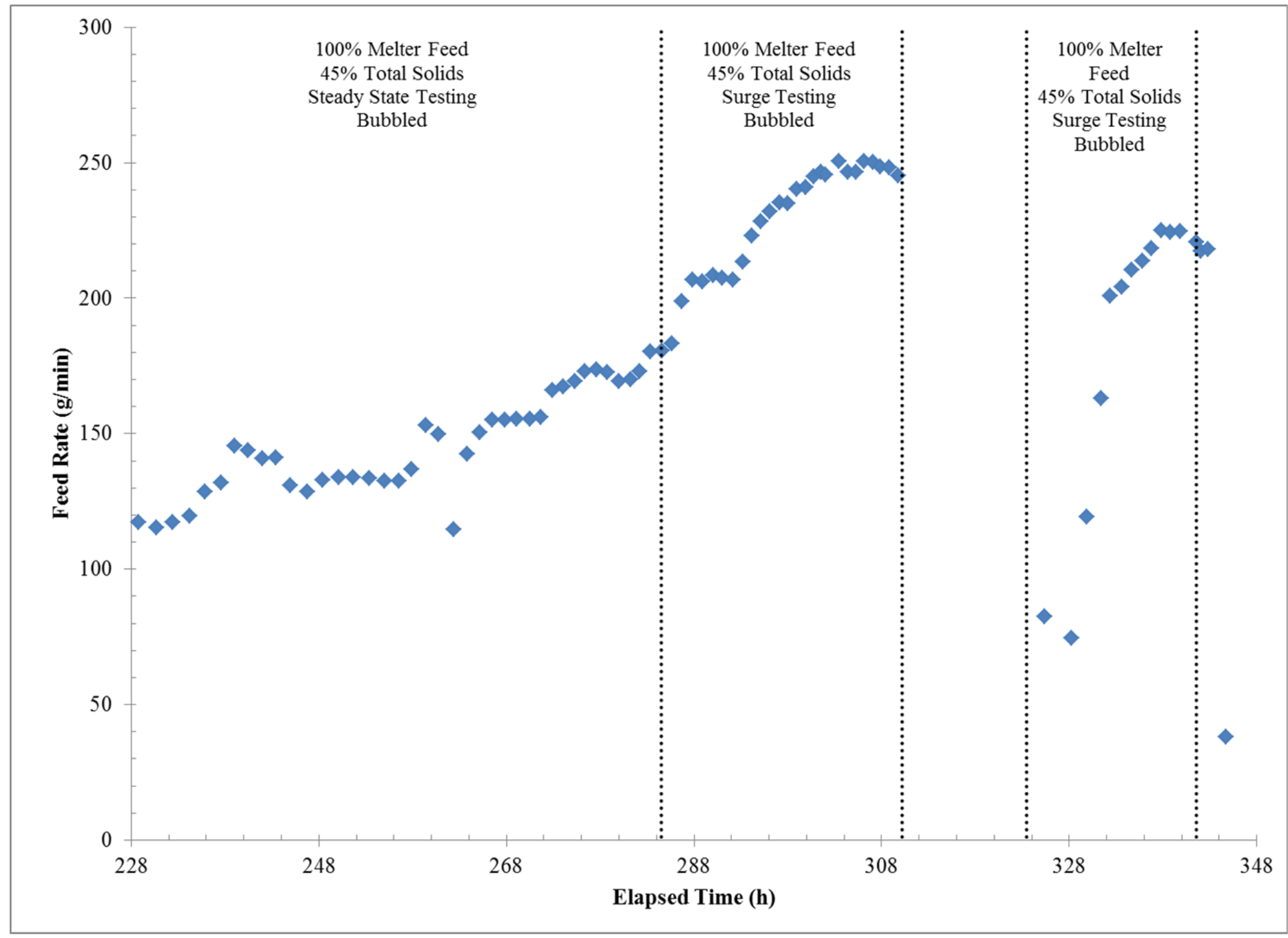

Figure A-43. Feed rate (elapsed time=228 at 00:00 March 6, 2014). 


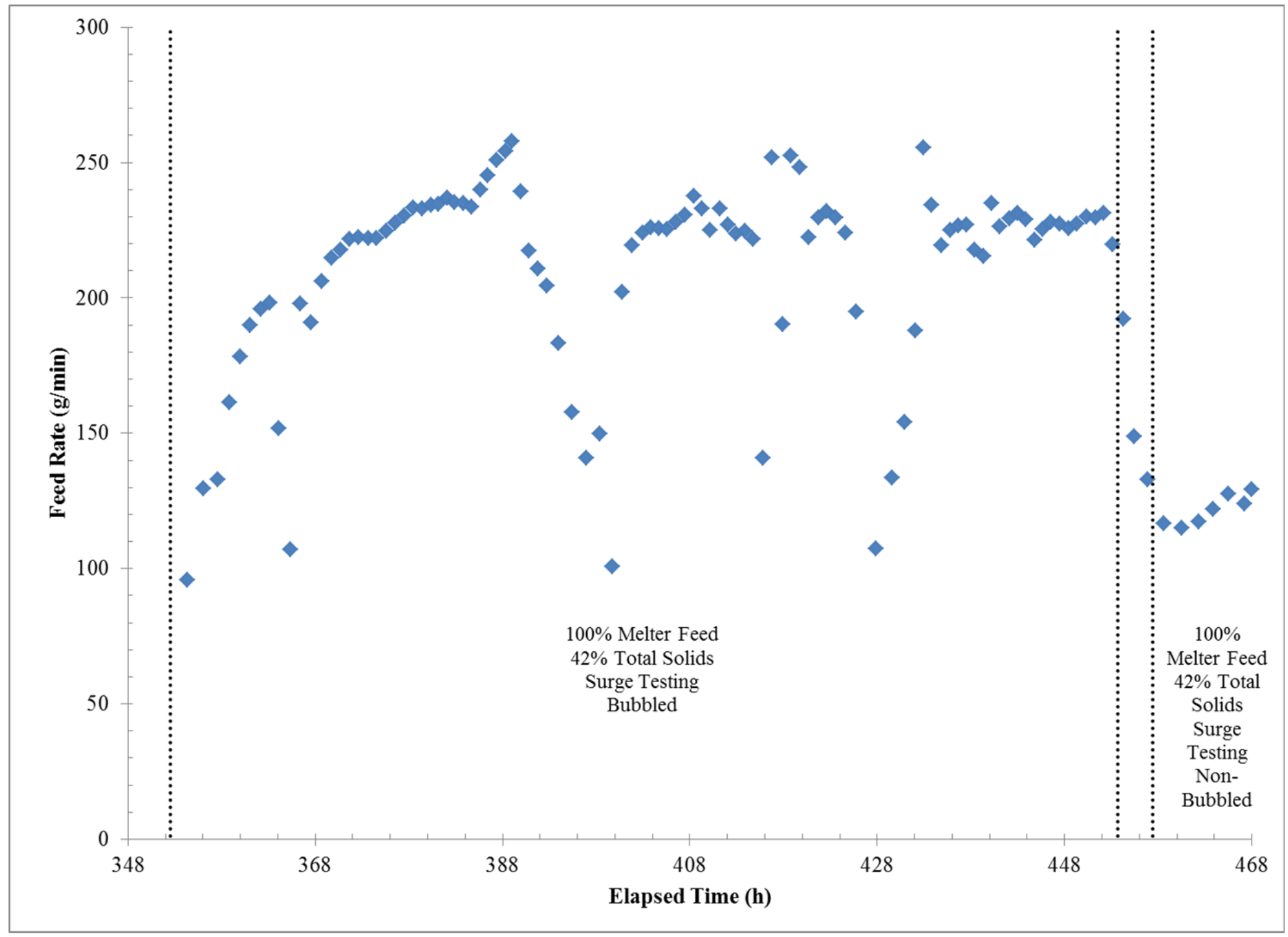

Figure A-44. Feed rate (elapsed time=348 at 00:00 March 11, 2014). 


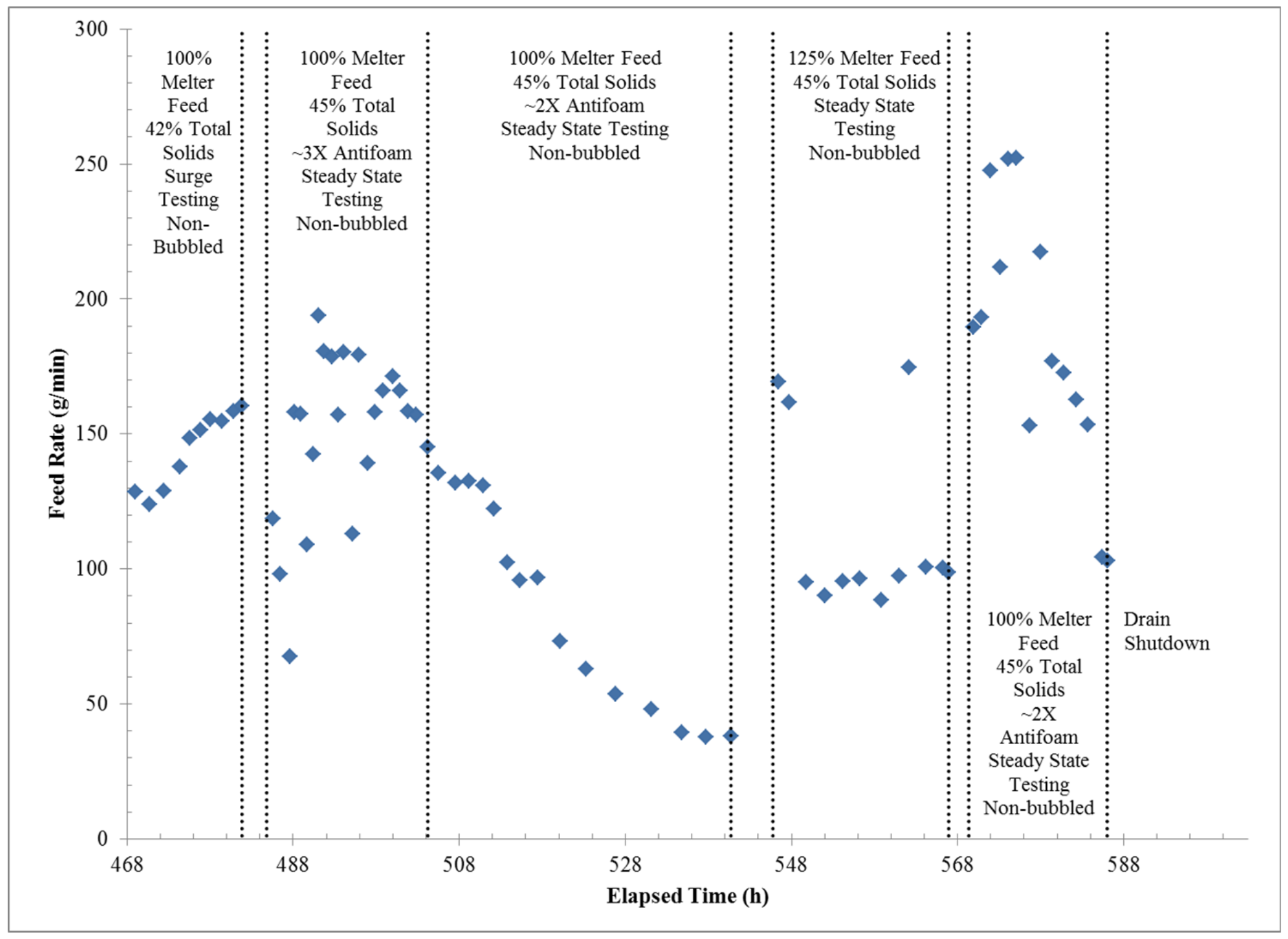

Figure A-45. Feed rate (elapsed time=468 at 00:00 March 16, 2014). 


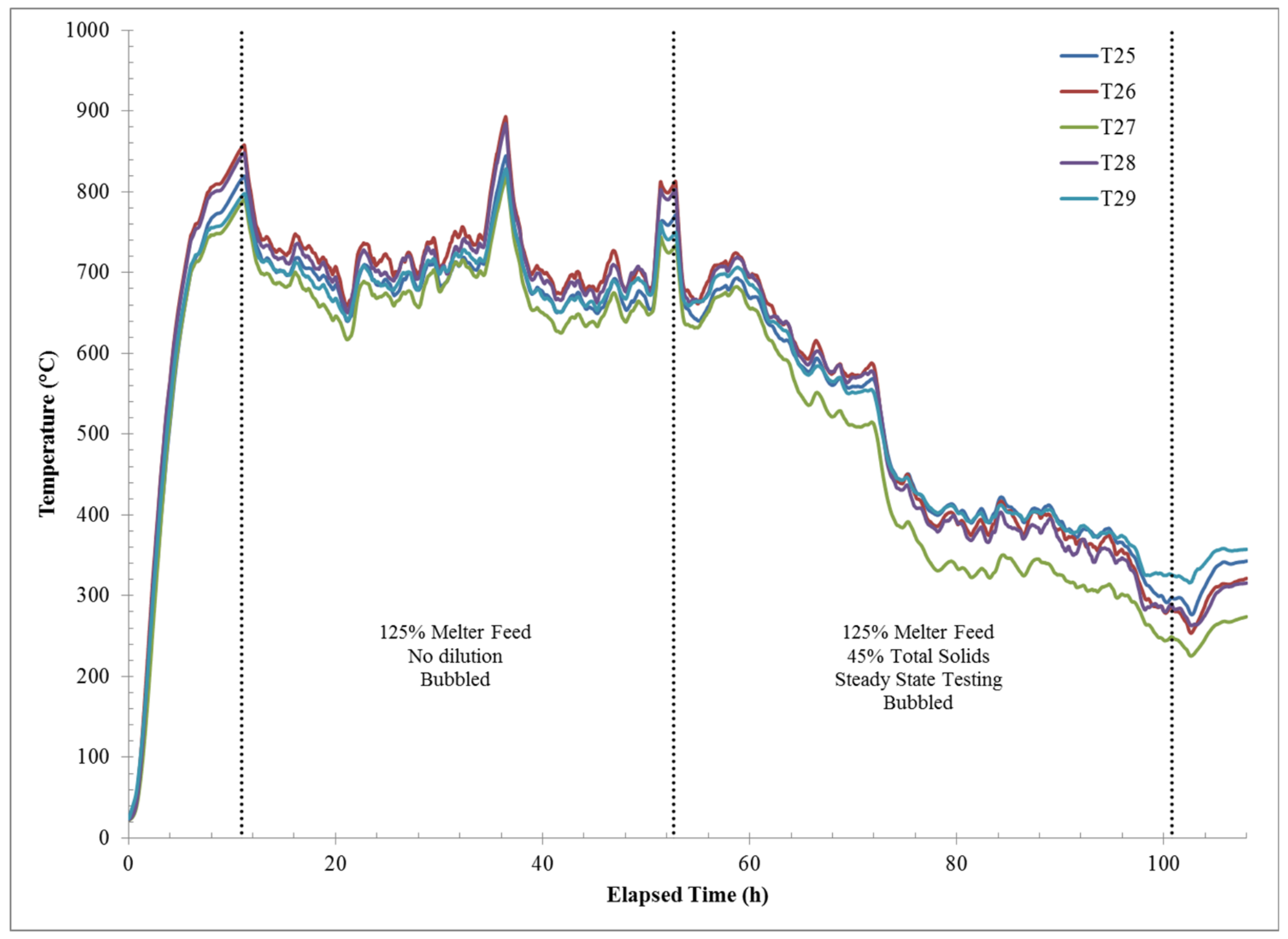

Figure A-46. Support block temperatures (elapsed time=0 at 12:00 February 24, 2014). 


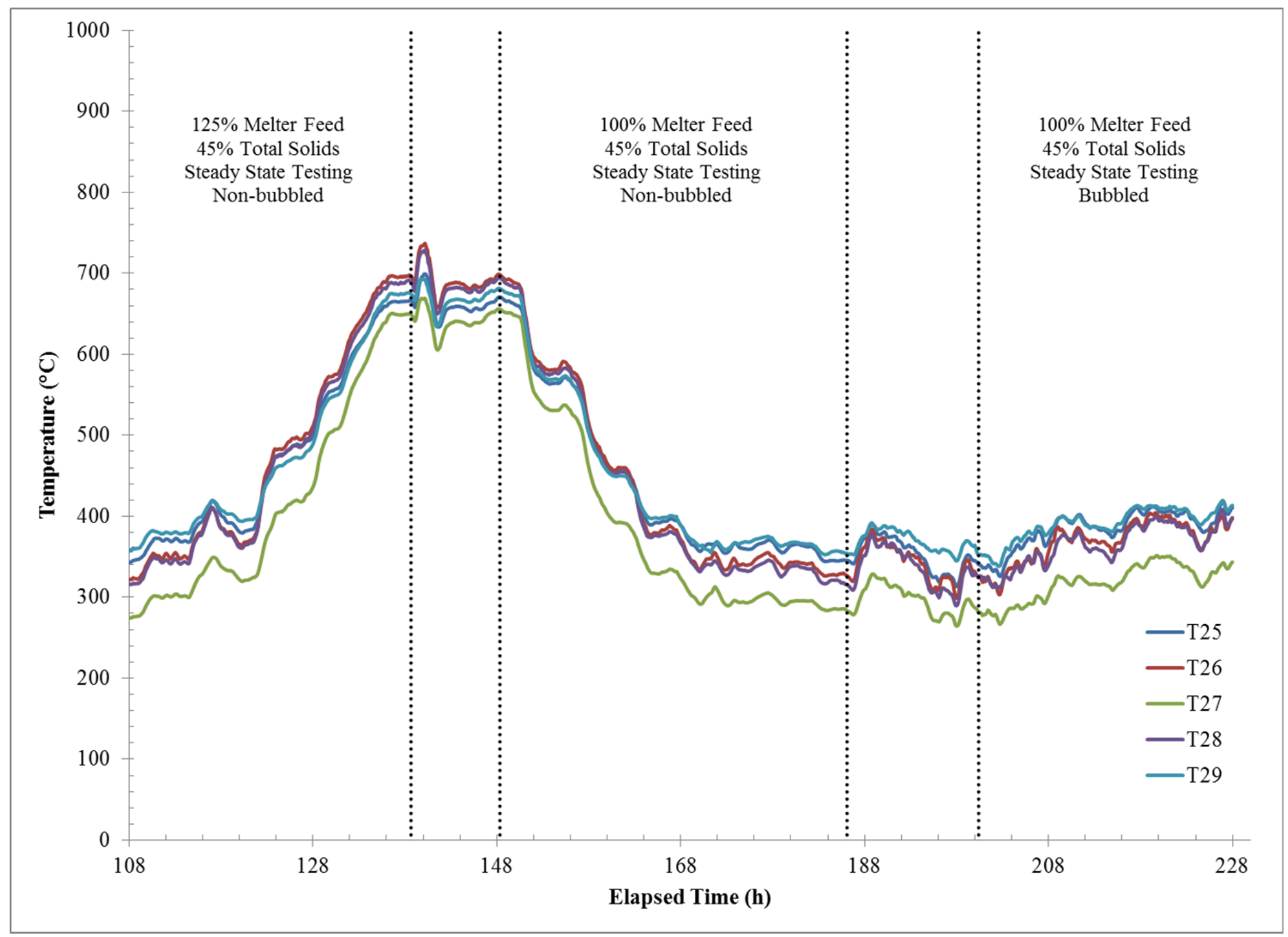

Figure A-47. Support block temperatures (elapsed time=108 at 00:00 March 1, 2014). 


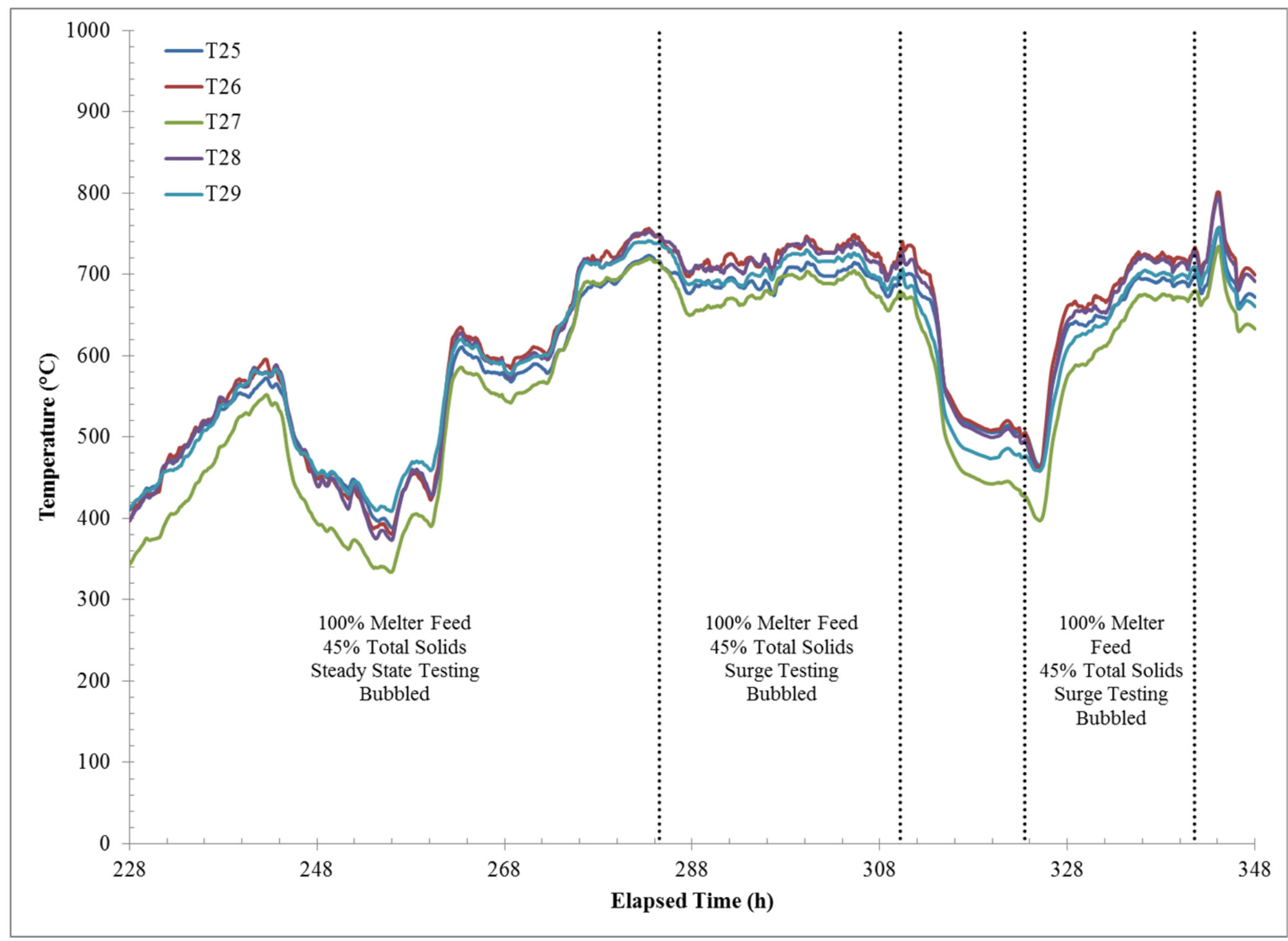

Figure A-48. Support block temperatures (elapsed time=228 at 00:00 March 6, 2014). 


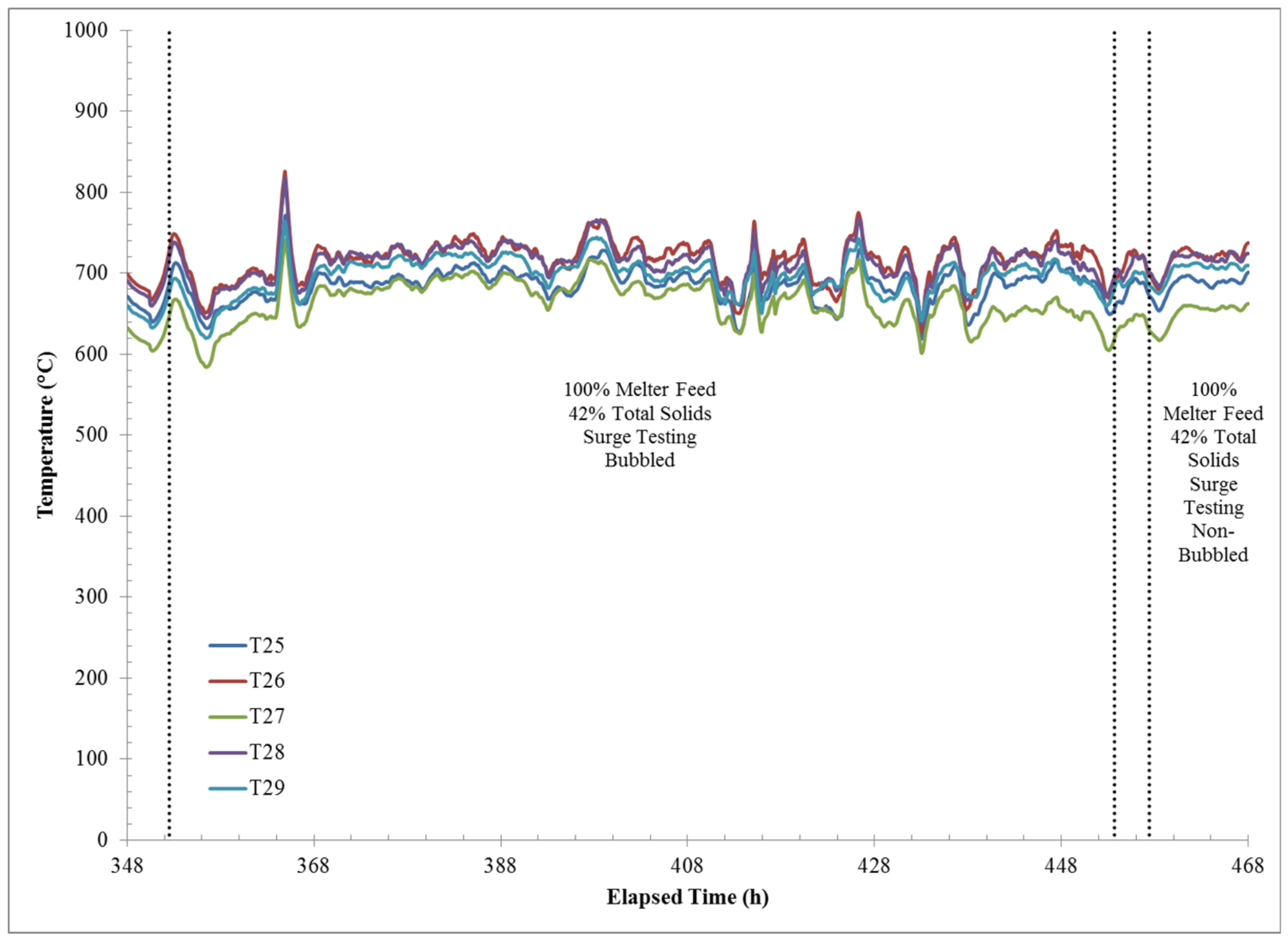

Figure A-49. Support block temperatures (elapsed time=348 at 00:00 March 11, 2014). 


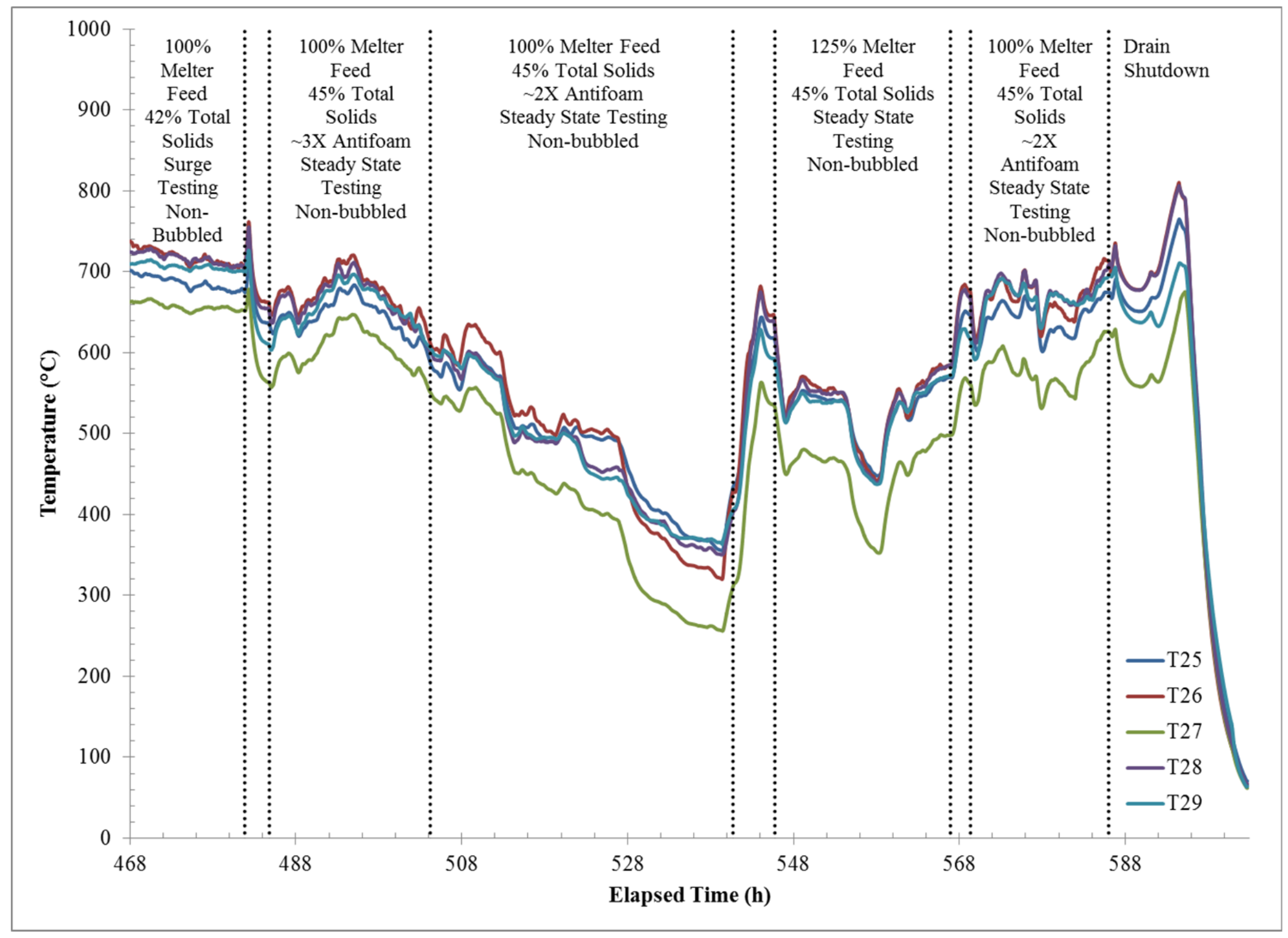

Figure A-50. Support block temperatures (elapsed time=468 at 00:00 March 16, 2014). 
Table A-3. Feed Sample Summary

\begin{tabular}{|c|c|c|c|c|c|c|}
\hline Sample ID & Lab ID & Collection Date & Collection Time & Feed Stoichoimetry & Total Solids Target & Antifoam Target \\
\hline CEF2-F-007 & S801 & $2 / 26 / 2014$ & $17: 20$ & $125 \%$ & $45 \%$ & nominal \\
\hline CEF2-F-008 & --- & $2 / 27 / 2014$ & $5: 45$ & $125 \%$ & $45 \%$ & nominal \\
\hline CEF2-F-009 & --- & $2 / 28 / 2014$ & $1: 30$ & $125 \%$ & $45 \%$ & nominal \\
\hline CEF2-F-010 & S802 & $2 / 28 / 2014$ & $16: 15$ & $125 \%$ & $45 \%$ & nominal \\
\hline CEF2-F-011 & S 820 & $3 / 2 / 2014$ & $8: 15$ & $100 \%$ & $45 \%$ & nominal \\
\hline CEF2-F-013 & S803 & $3 / 3 / 2014$ & $4: 33$ & $100 \%$ & $45 \%$ & nominal \\
\hline CEF2-F-015 & S804 & $3 / 5 / 2014$ & $5: 30$ & $100 \%$ & $45 \%$ & nominal \\
\hline CEF2-F-018 & S821 & $3 / 7 / 2014$ & $3: 00$ & $100 \%$ & $45 \%$ & nominal \\
\hline CEF2-F-023 & S822 & $3 / 9 / 2014$ & $7: 05$ & $100 \%$ & $45 \%$ & nominal \\
\hline CEF2-F-027 & S814 & $3 / 11 / 2014$ & 13:08 & $100 \%$ & $42 \%$ & nominal \\
\hline CEF2-F-030 & S815 & $3 / 12 / 2014$ & 18:00 & $100 \%$ & $42 \%$ & nominal \\
\hline CEF2-F-038 & S888 & $3 / 16 / 2014$ & $15: 45$ & $100 \%$ & $45 \%$ & $\sim 3 \mathrm{X}$ nominal \\
\hline CEF2-F-039 & S889 & $3 / 17 / 2014$ & $0: 35$ & $100 \%$ & $45 \%$ & $\sim 3 \mathrm{X}$ nominal \\
\hline CEF2-F-041 & S823 & $3 / 17 / 2014$ & $12: 10$ & $100 \%$ & $45 \%$ & $\sim 2 \mathrm{X}$ nominal \\
\hline CEF2-F-042 & S824 & $3 / 18 / 2014$ & $3: 50$ & $100 \%$ & $45 \%$ & $\sim 2 \mathrm{X}$ nominal \\
\hline CEF2-F-044 & S825 & $3 / 19 / 2014$ & $7: 40$ & $125 \%$ & $45 \%$ & nominal \\
\hline CEF2-F-047 & S826 & $3 / 20 / 2014$ & $16: 47$ & $100 \%$ & $45 \%$ & $\sim 2 \mathrm{X}$ nominal \\
\hline
\end{tabular}


Table A-4. ICP-AES Analysis of Feed Set $1 \mathrm{~A}$ (elemental wt\% calcined at $1100^{\circ} \mathrm{C}$ )

\begin{tabular}{|c|c|c|c|c|c|c|c|c|c|c|c|}
\hline Sample ID & Lab ID & Al & B & $\mathbf{B a}$ & $\mathrm{Ca}$ & $\mathrm{Cr}$ & $\mathrm{Cu}$ & $\mathbf{F e}$ & $\mathbf{K}$ & $\mathbf{L i}$ & Mg \\
\hline CEF2-F-007 (A) & S-801 & 5.57 & 1.47 & 0.045 & 0.402 & 0.069 & 0.027 & 8.34 & 0.143 & 2.28 & 0.320 \\
\hline CEF2-F-007 (B) & S-801 & 5.57 & 1.47 & 0.046 & 0.402 & 0.071 & 0.035 & 8.03 & 0.169 & 2.27 & 0.327 \\
\hline CEF2-F-010 (A) & S-802 & 5.62 & 1.49 & 0.044 & 0.390 & 0.069 & 0.046 & 8.02 & 0.155 & 2.33 & 0.315 \\
\hline CEF2-F-010 (B) & S-802 & 5.62 & 1.50 & 0.046 & 0.403 & 0.071 & 0.042 & 8.12 & 0.152 & 2.34 & 0.329 \\
\hline CEF2-F-013 (A) & S-803 & 5.61 & 1.43 & 0.048 & 0.434 & 0.073 & 0.039 & 8.59 & 0.149 & 2.25 & 0.356 \\
\hline CEF2-F-013 (B) & S-803 & 5.72 & 1.44 & 0.049 & 0.450 & 0.075 & 0.052 & 8.76 & 0.157 & 2.23 & 0.363 \\
\hline CEF2-F-015 (A) & S-804 & 5.79 & 1.39 & 0.050 & 0.466 & 0.077 & 0.048 & 9.14 & 0.159 & 2.16 & 0.380 \\
\hline CEF2-F-015 (B) & S-804 & 5.83 & 1.38 & 0.051 & 0.471 & 0.078 & 0.053 & 9.21 & 0.156 & 2.15 & 0.386 \\
\hline CEF2-F-027 (A) & S-814 & 4.72 & 1.75 & 0.048 & 0.414 & 0.065 & 0.051 & 7.27 & 0.147 & 2.38 & 0.315 \\
\hline CEF2-F-027 (B) & S-814 & 4.85 & 1.79 & 0.048 & 0.410 & 0.065 & 0.049 & 7.44 & 0.141 & 2.46 & 0.309 \\
\hline CEF2-F-030 (A) & S-815 & 4.93 & 1.75 & 0.048 & 0.410 & 0.066 & 0.053 & 7.61 & 0.144 & 2.41 & 0.318 \\
\hline CEF2-F-030 (B) & S-815 & 4.83 & 1.68 & 0.049 & 0.407 & 0.068 & 0.047 & 7.46 & 0.144 & 2.36 & 0.318 \\
\hline CEF2-F-038 (A) & S-888 & 5.13 & 1.49 & 0.050 & 0.408 & 0.072 & 0.042 & 7.82 & 0.160 & 2.28 & 0.308 \\
\hline CEF2-F-038 (B) & S-888 & 5.12 & 1.50 & 0.050 & 0.410 & 0.072 & 0.042 & 7.85 & 0.153 & 2.29 & 0.311 \\
\hline CEF2-F-039 (A) & S-889 & 4.96 & 1.55 & 0.048 & 0.412 & 0.069 & 0.042 & 7.52 & 0.154 & 2.35 & 0.303 \\
\hline CEF2-F-039 (B) & S-889 & 4.99 & 1.54 & 0.049 & 0.408 & 0.071 & 0.041 & 7.55 & 0.155 & 2.35 & 0.310 \\
\hline CEF2-F-041 (A) & S-823 & 5.66 & 1.43 & 0.053 & 0.402 & 0.077 & 0.051 & 8.70 & 0.153 & 2.10 & 0.328 \\
\hline CEF2-F-041 (B) & S-823 & 5.75 & 1.39 & 0.055 & 0.420 & 0.079 & 0.057 & 8.58 & 0.168 & 2.07 & 0.338 \\
\hline CEF2-F-042 (A) & S-824 & 4.88 & 1.60 & 0.047 & 0.386 & 0.070 & 0.047 & 7.44 & 0.143 & 2.24 & 0.313 \\
\hline CEF2-F-042 (B) & $\mathrm{S}-824$ & 4.86 & 1.57 & 0.047 & 0.381 & 0.070 & 0.045 & 7.44 & 0.142 & 2.19 & 0.313 \\
\hline CEF2-F-044 (A) & $\mathrm{S}-825$ & 5.08 & 1.55 & 0.047 & 0.371 & 0.071 & 0.041 & 7.52 & 0.142 & 2.30 & 0.306 \\
\hline CEF2-F-044 (B) & S-825 & 5.00 & 1.54 & 0.047 & 0.372 & 0.071 & 0.040 & 7.44 & 0.144 & 2.26 & 0.306 \\
\hline CEF2-F-047 (A) & S-826 & 5.27 & 1.45 & 0.053 & 0.433 & 0.076 & 0.046 & 8.20 & 0.154 & 2.07 & 0.351 \\
\hline CEF2-F-047 (B) & S-826 & 5.35 & 1.41 & 0.053 & 0.433 & 0.077 & 0.044 & 8.13 & 0.154 & 2.06 & 0.350 \\
\hline
\end{tabular}


Table A-5. ICP-AES Analysis of Feed Set $1 \mathrm{~B}$ (elemental wt\% calcined at $1100^{\circ} \mathrm{C}$ )

\begin{tabular}{|c|c|c|c|c|c|c|c|c|c|c|c|c|}
\hline Sample ID & Lab ID & Mn & $\mathbf{N a}$ & $\mathbf{N i}$ & $\mathbf{P}$ & $\mathbf{P b}$ & $\mathbf{S}$ & Si & Sn & $\mathbf{T i}$ & $\mathbf{Z n}$ & $\mathbf{Z r}$ \\
\hline CEF2-F-007 (A) & S-801 & 2.36 & 9.20 & 0.993 & $<0.100$ & $<0.100$ & 0.109 & 22.5 & $<0.100$ & $<0.100$ & $<0.100$ & 0.100 \\
\hline CEF2-F-007 (B) & S-801 & 2.32 & 9.15 & 0.969 & $<0.100$ & $<0.100$ & 0.114 & 22.3 & $<0.100$ & $<0.100$ & $<0.100$ & 0.103 \\
\hline CEF2-F-010 (A) & $\mathrm{S}-802$ & 2.37 & 9.24 & 1.01 & $<0.100$ & $<0.100$ & 0.103 & 22.8 & $<0.100$ & $<0.100$ & $<0.100$ & 0.097 \\
\hline CEF2-F-010 (B) & S-802 & 2.38 & 9.08 & 1.01 & $<0.100$ & $<0.100$ & 0.106 & 22.9 & $<0.100$ & $<0.100$ & $<0.100$ & 0.102 \\
\hline CEF2-F-013 (A) & $\mathrm{S}-803$ & 2.74 & 9.28 & 1.12 & $<0.100$ & $<0.100$ & 0.121 & 22.1 & $<0.100$ & $<0.100$ & $<0.100$ & 0.104 \\
\hline CEF2-F-013 (B) & S-803 & 2.73 & 9.17 & 1.12 & $<0.100$ & $<0.100$ & 0.118 & 21.9 & $<0.100$ & $<0.100$ & $<0.100$ & 0.106 \\
\hline CEF2-F-015 (A) & S-804 & 2.92 & 9.47 & 1.20 & $<0.100$ & $<0.100$ & 0.133 & 21.4 & $<0.100$ & $<0.100$ & $<0.100$ & 0.106 \\
\hline CEF2-F-015 (B) & S-804 & 2.91 & 9.42 & 1.20 & $<0.100$ & $<0.100$ & 0.136 & 21.3 & $<0.100$ & $<0.100$ & $<0.100$ & 0.107 \\
\hline CEF2-F-027 (A) & S-814 & 2.40 & 8.77 & 1.04 & $<0.100$ & $<0.100$ & 0.112 & 24.7 & $<0.100$ & $<0.100$ & $<0.100$ & 0.106 \\
\hline CEF2-F-027 (B) & S-814 & 2.35 & 8.57 & 1.06 & $<0.100$ & $<0.100$ & 0.109 & 24.2 & $<0.100$ & $<0.100$ & $<0.100$ & 0.104 \\
\hline CEF2-F-030 (A) & S-815 & 2.36 & 8.63 & 1.10 & $<0.100$ & $<0.100$ & 0.111 & 23.5 & $<0.100$ & $<0.100$ & $<0.100$ & 0.106 \\
\hline CEF2-F-030 (B) & $\mathrm{S}-815$ & 2.36 & 8.80 & 1.05 & $<0.100$ & $<0.100$ & 0.108 & 23.2 & $<0.100$ & $<0.100$ & $<0.100$ & 0.106 \\
\hline CEF2-F-038 (A) & $\mathrm{S}-888$ & 2.42 & 8.45 & 1.03 & $<0.100$ & $<0.100$ & 0.116 & 23.8 & $<0.100$ & $<0.100$ & $<0.100$ & 0.116 \\
\hline CEF2-F-038 (B) & S-888 & 2.44 & 8.52 & 1.04 & $<0.100$ & $<0.100$ & 0.122 & 23.9 & $<0.100$ & $<0.100$ & $<0.100$ & 0.116 \\
\hline CEF2-F-039 (A) & S-889 & 2.38 & 8.51 & 1.01 & $<0.100$ & $<0.100$ & 0.117 & 24.2 & $<0.100$ & $<0.100$ & $<0.100$ & 0.115 \\
\hline CEF2-F-039 (B) & S-889 & 2.39 & 8.74 & 1.00 & $<0.100$ & $<0.100$ & 0.121 & 24.1 & $<0.100$ & $<0.100$ & $<0.100$ & 0.116 \\
\hline CEF2-F-041 (A) & $\mathrm{S}-823$ & 2.64 & 9.01 & 1.13 & $<0.100$ & $<0.100$ & 0.107 & 21.0 & $<0.100$ & $<0.100$ & $<0.100$ & 0.118 \\
\hline CEF2-F-041 (B) & $\mathrm{S}-823$ & 2.60 & 9.16 & 1.11 & $<0.100$ & $<0.100$ & 0.110 & 21.2 & $<0.100$ & $<0.100$ & $<0.100$ & 0.121 \\
\hline CEF2-F-042 (A) & S-824 & 2.43 & 8.70 & 1.01 & $<0.100$ & $<0.100$ & 0.111 & 24.0 & $<0.100$ & $<0.100$ & $<0.100$ & 0.107 \\
\hline CEF2-F-042 (B) & S-824 & 2.36 & 8.85 & 0.973 & $<0.100$ & $<0.100$ & 0.108 & 23.9 & $<0.100$ & $<0.100$ & $<0.100$ & 0.107 \\
\hline CEF2-F-044 (A) & $\mathrm{S}-825$ & 2.34 & 8.84 & 1.00 & $<0.100$ & $<0.100$ & 0.091 & 23.8 & $<0.100$ & $<0.100$ & $<0.100$ & 0.107 \\
\hline CEF2-F-044 (B) & S-825 & 2.31 & 8.79 & 0.992 & $<0.100$ & $<0.100$ & 0.092 & 23.8 & $<0.100$ & $<0.100$ & $<0.100$ & 0.107 \\
\hline CEF2-F-047 (A) & S-826 & 2.69 & 9.10 & 1.11 & $<0.100$ & $<0.100$ & 0.124 & 22.6 & $<0.100$ & $<0.100$ & $<0.100$ & 0.118 \\
\hline CEF2-F-047 (B) & S-826 & 2.66 & 9.11 & 1.11 & $<0.100$ & $<0.100$ & 0.123 & 22.1 & $<0.100$ & $<0.100$ & $<0.100$ & 0.117 \\
\hline
\end{tabular}


Table A-6. IC Analysis by PSAL of Feed Anions (mg/Kg)

\begin{tabular}{|c|c|c|c|c|c|c|c|c|c|c|}
\hline Sample ID & Lab ID & $\mathbf{F}$ & $\mathrm{Cl}$ & $\mathrm{NO}_{2}$ & $\mathrm{NO}_{3}$ & $\mathrm{C}_{2} \mathrm{H}_{3} \mathrm{O}_{3}$ & $\mathrm{SO}_{4}$ & $\mathrm{C}_{2} \mathrm{O}_{4}$ & $\mathrm{HCO}_{2}$ & $\mathrm{PO}_{4}$ \\
\hline CEF2-F-007 (A) & S-801 & $<100$ & 302 & $<100$ & 68000 & 36400 & 1440 & 1300 & 1980 & $<100$ \\
\hline CEF2-F-007 (B) & S-801 & $<100$ & 300 & $<100$ & 68000 & 36300 & 1440 & 1170 & 1950 & $<100$ \\
\hline CEF2-F-010 (A) & S-802 & $<100$ & 305 & $<100$ & 65600 & 34800 & 1460 & 1430 & 2130 & $<100$ \\
\hline CEF2-F-010 (B) & S-802 & $<100$ & 276 & $<100$ & 64600 & 35100 & 1490 & 1250 & 1800 & $<100$ \\
\hline CEF2-F-013 (A) & S-803 & $<100$ & 306 & $<100$ & 63000 & 27400 & 1400 & 962 & 2440 & $<100$ \\
\hline CEF2-F-013 (B) & S-803 & $<100$ & 308 & $<100$ & 62100 & 26500 & 1410 & 943 & 2430 & $<100$ \\
\hline CEF2-F-015 (A) & S-804 & $<100$ & 300 & $<100$ & 60400 & 26300 & 1400 & 905 & 2390 & $<100$ \\
\hline CEF2-F-015 (B) & S-804 & $<100$ & 328 & $<100$ & 60300 & 26200 & 1410 & 901 & 2390 & $<100$ \\
\hline CEF2-F-027 (A) & $\mathrm{S}-814$ & $<100$ & 271 & $<100$ & 49000 & 27900 & 1140 & 977 & 1500 & $<100$ \\
\hline CEF2-F-027 (B) & S-814 & $<100$ & 273 & $<100$ & 48600 & 28000 & 1190 & 1020 & 1520 & $<100$ \\
\hline CEF2-F-030 (A) & S-815 & $<100$ & 275 & $<100$ & 47900 & 30200 & 1100 & 960 & 1570 & $<100$ \\
\hline CEF2-F-030 (B) & S-815 & $<100$ & 273 & $<100$ & 47800 & 30300 & 1120 & 964 & 1570 & $<100$ \\
\hline CEF2-F-038 (A) & S-888 & $<100$ & 282 & $<100$ & 52400 & 27100 & 932 & 1040 & 2030 & $<100$ \\
\hline CEF2-F-038 (B) & S-888 & $<100$ & 278 & $<100$ & 52400 & 27200 & 932 & 1020 & 2000 & $<100$ \\
\hline CEF2-F-039 (A) & S-889 & $<100$ & 278 & $<100$ & 52900 & 26400 & 960 & 1010 & 2020 & $<100$ \\
\hline CEF2-F-039 (B) & S-889 & $<100$ & 280 & $<100$ & 53100 & 26400 & 952 & 1030 & 2050 & $<100$ \\
\hline CEF2-F-041 (A) & S-823 & $<100$ & 291 & $<100$ & 57500 & 31400 & 869 & 980 & 1960 & $<100$ \\
\hline CEF2-F-041 (B) & S-823 & $<100$ & 301 & $<100$ & 56700 & 31800 & 896 & 976 & 1970 & $<100$ \\
\hline CEF2-F-042 (A) & S-824 & $<100$ & 282 & $<100$ & 53200 & 30000 & 847 & 927 & 1850 & $<100$ \\
\hline CEF2-F-042 (B) & S-824 & $<100$ & 285 & $<100$ & 53800 & 30100 & 824 & 889 & 1840 & $<100$ \\
\hline CEF2-F-044 (A) & S-825 & $<100$ & 274 & $<100$ & 59200 & 38900 & 827 & 1130 & 840 & $<100$ \\
\hline CEF2-F-044 (B) & S-825 & $<100$ & 274 & $<100$ & 58100 & 39200 & 881 & 1210 & 880 & $<100$ \\
\hline CEF2-F-047 (A) & S-826 & $<100$ & 296 & $<100$ & 55200 & 32000 & 822 & 937 & 1670 & $<100$ \\
\hline CEF2-F-047 (B) & S-826 & $<100$ & 288 & $<100$ & 55000 & 30900 & 864 & 957 & 1740 & $<100$ \\
\hline
\end{tabular}


Table A-7. IC Analysis by AD of Feed Anions (mg/Kg)

\begin{tabular}{lcccccccccc}
\hline Sample ID & $\mathbf{L a b}$ ID & $\mathbf{F}$ & $\mathbf{C l}$ & $\mathbf{N O}_{\mathbf{2}}$ & $\mathbf{N O}_{\mathbf{3}}$ & $\mathbf{C}_{\mathbf{2}} \mathbf{H}_{\mathbf{3}} \mathbf{O}_{\mathbf{3}}$ & $\mathbf{S O}_{\mathbf{4}}$ & $\mathbf{C}_{\mathbf{2}} \mathbf{O}_{\mathbf{4}}$ & $\mathbf{H C O}_{\mathbf{2}}$ & $\mathbf{P O}_{\mathbf{4}}$ \\
\hline CEF2-F-007 & 300311426 & $<500$ & $<500$ & $<500$ & 67730 & 41755 & 1275 & 1394 & 769 & $<500$ \\
\hline CEF2-F-010 & 300311427 & $<500$ & $<500$ & $<500$ & 66952 & 44744 & 1290 & 1042 & 760 & $<500$ \\
\hline CEF2-F-013 & 300311428 & $<500$ & $<500$ & $<500$ & 58632 & 34691 & 1343 & 1121 & 1701 & $<500$ \\
\hline CEF2-F-015 & 300311429 & $<500$ & $<500$ & $<500$ & 58977 & 34639 & 1241 & 1138 & 1741 & $<500$ \\
\hline CEF2-F-041 & 300311430 & $<500$ & $<500$ & $<500$ & 63061 & 36778 & 1332 & 1178 & 1849 & $<500$ \\
\hline CEF2-F-042 & 300311431 & $<500$ & $<500$ & $<500$ & 60459 & 35699 & 1295 & 1127 & 1724 & $<500$ \\
\hline
\end{tabular}


Table A-8. ICP-AES Analysis of Feed Supernate Cations Set 1A (mg/L)

\begin{tabular}{|c|c|c|c|c|c|c|c|c|c|c|c|c|}
\hline Sample ID & Lab ID & Al & B & $\mathbf{B a}$ & $\mathbf{C a}$ & Cd & $\mathrm{Cr}$ & $\mathbf{C u}$ & $\mathbf{F e}$ & $\mathbf{K}$ & $\mathbf{L i}$ & Mg \\
\hline CEF2-F-007 (A) & S-801 & 1260 & 41.9 & 4.06 & 2730 & $<0.100$ & 7.65 & 196 & 3530 & 717 & 106 & 1400 \\
\hline CEF2-F-007 (B) & S-801 & 1270 & 41.5 & 4.05 & 2750 & $<0.100$ & 7.70 & 197 & 3540 & 702 & 107 & 1400 \\
\hline CEF2-F-010 (A) & S-802 & 1200 & 33.1 & 3.85 & 2580 & $<0.100$ & 7.15 & 185 & 3400 & 691 & 95.7 & 1320 \\
\hline CEF2-F-010 (B) & S-802 & 1200 & 33.0 & 3.84 & 2580 & $<0.100$ & 7.18 & 185 & 3450 & 683 & 94.8 & 1330 \\
\hline CEF2-F-013 (A) & S-803 & 507 & 27.5 & 2.01 & 2430 & $<0.100$ & 2.97 & 126 & 863 & 635 & 87.0 & 1570 \\
\hline CEF2-F-013 (B) & S-803 & 508 & 27.5 & 1.99 & 2900 & $<0.100$ & 2.99 & 125 & 866 & 633 & 86.6 & 1570 \\
\hline CEF2-F-015 (A) & S-804 & 496 & 27.8 & 1.97 & 2460 & $<0.100$ & 2.87 & 127 & 872 & 659 & 86.7 & 1600 \\
\hline CEF2-F-015 (B) & S-804 & 496 & 27.2 & 1.96 & 2450 & $<0.100$ & 2.85 & 125 & 877 & 687 & 86.2 & 1600 \\
\hline CEF2-F-027 (A) & S-814 & 510 & 22.9 & 1.53 & 2230 & $<0.100$ & 2.59 & 112 & 940 & 530 & 71.5 & 1750 \\
\hline CEF2-F-027 (B) & S-814 & 514 & 22.1 & 1.52 & 2220 & $<0.100$ & 2.60 & 112 & 919 & 540 & 71.5 & 1750 \\
\hline CEF2-F-030 (A) & S-815 & 479 & 19.0 & 1.45 & 2140 & $<0.100$ & 2.42 & 106 & 941 & 523 & 60.3 & 1660 \\
\hline CEF2-F-030 (B) & S-815 & 478 & 19.2 & 1.45 & 2140 & $<0.100$ & 2.44 & 107 & 941 & 522 & 60.2 & 1670 \\
\hline CEF2-F-038 (A) & S-888 & 452 & 30.6 & 1.64 & 2630 & $<0.100$ & 3.73 & 114 & 461 & 536 & 103 & 1958 \\
\hline CEF2-F-038 (B) & S-888 & 453 & 30.5 & 1.64 & 2630 & $<0.100$ & 3.74 & 113 & 472 & 553 & 103 & 1955 \\
\hline CEF2-F-039 (A) & S-889 & 430 & 31.2 & 1.70 & 2640 & $<0.100$ & 3.81 & 114 & 418 & 569 & 103 & 1996 \\
\hline CEF2-F-039 (B) & S-889 & 431 & 31.4 & 1.67 & 2650 & $<0.100$ & 3.79 & 114 & 426 & 575 & 103 & 2105 \\
\hline CEF2-F-041 (A) & S-823 & 534 & 30.9 & 2.03 & 2610 & $<0.100$ & 3.40 & 121 & 691 & 736 & 100 & 2050 \\
\hline CEF2-F-041 (B) & S-823 & 537 & 30.2 & 2.02 & 2600 & $<0.100$ & 3.37 & 121 & 691 & 741 & 100 & 2060 \\
\hline CEF2-F-042 (A) & S-824 & 520 & 30.2 & 1.95 & 2540 & $<0.100$ & 3.25 & 120 & 672 & 735 & 103 & 2030 \\
\hline CEF2-F-042 (B) & S-824 & 516 & 30.1 & 1.97 & 2570 & $<0.100$ & 3.32 & 119 & 653 & 724 & 103 & 2050 \\
\hline CEF2-F-044 (A) & S-825 & 1280 & 35.6 & 3.68 & 2640 & $<0.100$ & 7.46 & 167 & 3230 & 730 & 111 & 1410 \\
\hline CEF2-F-044 (B) & S-825 & 1280 & 35.4 & 3.69 & 2640 & $<0.100$ & 7.46 & 169 & 3180 & 722 & 111 & 1420 \\
\hline CEF2-F-047 (A) & S-826 & 510 & 31.7 & 1.97 & 2530 & $<0.100$ & 3.21 & 114 & 702 & 728 & 103 & 2010 \\
\hline CEF2-F-047 (B) & S-826 & 513 & 31.9 & 1.96 & 2580 & $<0.100$ & 3.12 & 117 & 700 & 739 & 105 & 2040 \\
\hline
\end{tabular}


Table A-9. ICP-AES Analysis of Feed Supernate Cations Set 1B (mg/L)

\begin{tabular}{|c|c|c|c|c|c|c|c|c|c|c|c|c|}
\hline Sample ID & Lab ID & Mn & $\mathbf{N a}$ & $\mathbf{N i}$ & $\mathbf{P}$ & $\mathbf{P b}$ & $\mathbf{S}$ & $\mathbf{S i}$ & Sn & $\mathbf{T i}$ & $\mathbf{Z n}$ & $\mathbf{Z r}$ \\
\hline CEF2-F-007 (A) & S-801 & 12300 & 31400 & 2210 & 34.9 & 4.15 & 761 & 279 & 11.5 & 5.69 & 78.0 & $<1.00$ \\
\hline CEF2-F-007 (B) & S-801 & 12400 & 31700 & 2200 & 35.6 & 4.13 & 750 & 275 & 11.5 & 5.72 & 76.7 & $<1.00$ \\
\hline CEF2-F-010 (A) & S-802 & 11800 & 30800 & 2100 & 32.1 & 3.74 & 685 & 276 & 10.9 & 5.28 & 74.2 & $<1.00$ \\
\hline CEF2-F-010 (B) & S-802 & 11700 & 30100 & 2110 & 33.4 & 3.90 & 683 & 270 & 10.9 & 5.29 & 74.3 & $<1.00$ \\
\hline CEF2-F-013 (A) & S-803 & 14100 & 28700 & 2910 & $<10.0$ & 1.81 & 699 & 578 & 10.8 & 1.78 & 84.2 & $<1.00$ \\
\hline CEF2-F-013 (B) & S-803 & 14200 & 29400 & 2940 & $<10.0$ & 1.94 & 712 & 577 & 10.9 & 1.77 & 83.6 & $<1.00$ \\
\hline CEF2-F-015 (A) & S-804 & 14300 & 28900 & 2980 & $<10.0$ & 1.94 & 732 & 381 & 11.2 & 1.70 & 83.9 & $<1.00$ \\
\hline CEF2-F-015 (B) & S-804 & 14300 & 29500 & 2980 & $<10.0$ & 1.95 & 734 & 386 & 10.8 & 1.74 & 82.5 & $<1.00$ \\
\hline CEF2-F-027 (A) & S-814 & 12800 & 27000 & 2690 & 3.98 & 1.42 & 660 & 371 & 8.5 & 1.60 & 73.2 & $<1.00$ \\
\hline CEF2-F-027 (B) & S-814 & 12800 & 27400 & 2690 & 3.46 & 1.25 & 647 & 379 & 8.52 & 1.61 & 73.3 & $<1.00$ \\
\hline CEF2-F-030 (A) & S-815 & 12200 & 26000 & 2530 & 2.66 & 1.21 & 653 & 340 & 8.23 & 1.46 & 69.6 & $<1.00$ \\
\hline CEF2-F-030 (B) & S-815 & 12200 & 26100 & 2520 & 3.60 & 1.31 & 643 & 342 & 8.15 & 1.46 & 71.4 & $<1.00$ \\
\hline CEF2-F-038 (A) & S-888 & 14078 & 26600 & 3410 & 2.29 & 1.55 & 684 & 1451 & 8.91 & 2.62 & 87.3 & $<1.00$ \\
\hline CEF2-F-038 (B) & S-888 & 13980 & 26800 & 3410 & 2.80 & 1.54 & 687 & 1383 & 9.07 & 2.61 & 87.3 & $<1.00$ \\
\hline CEF2-F-039 (A) & S-889 & 13300 & 27200 & 3330 & 2.26 & 1.61 & 697 & 1028 & 9.03 & 2.72 & 90.7 & $<1.00$ \\
\hline CEF2-F-039 (B) & S-889 & 13300 & 27200 & 3340 & 2.70 & 1.54 & 692 & 1009 & 9.16 & 2.73 & 92.0 & $<1.00$ \\
\hline CEF2-F-041 (A) & S-823 & 14500 & 30300 & 3300 & 3.28 & 1.59 & 769 & 722 & 11.1 & 2.34 & 94.7 & $<1.00$ \\
\hline CEF2-F-041 (B) & S-823 & 14400 & 29400 & 3350 & 3.31 & 1.61 & 775 & 717 & 11.0 & 2.33 & 94.7 & $<1.00$ \\
\hline CEF2-F-042 (A) & S-824 & 14300 & 28400 & 3280 & 3.38 & 1.53 & 773 & 716 & 10.8 & 2.27 & 92.5 & $<1.00$ \\
\hline CEF2-F-042 (B) & S-824 & 14300 & 30200 & 3340 & 3.81 & 1.61 & 756 & 705 & 10.8 & 2.30 & 93.5 & $<1.00$ \\
\hline CEF2-F-044 (A) & S-825 & 11500 & 31400 & 1920 & 30.6 & 3.33 & 738 & 288 & 10.0 & 5.32 & 64.4 & $<1.00$ \\
\hline CEF2-F-044 (B) & S-825 & 11500 & 31400 & 1920 & 31.3 & 3.32 & 734 & 282 & 10.2 & 5.36 & 64.6 & $<1.00$ \\
\hline CEF2-F-047 (A) & S-826 & 14100 & 29700 & 3220 & 3.68 & 1.65 & 739 & 733 & 10.6 & 2.20 & 88.9 & $<1.00$ \\
\hline CEF2-F-047 (B) & S-826 & 14200 & 29800 & 3260 & 2.93 & 1.63 & 747 & 752 & 10.6 & 2.21 & 89.6 & $<1.00$ \\
\hline
\end{tabular}


Table A-10. IC Analysis by PSAL of Feed Supernate Anions (mg/L)

\begin{tabular}{|c|c|c|c|c|c|c|c|c|c|c|}
\hline Sample ID & Lab ID & $\mathbf{F}$ & $\mathrm{Cl}$ & $\mathrm{NO}_{2}$ & $\mathbf{N O}_{3}$ & $\mathrm{C}_{2} \mathrm{H}_{3} \mathrm{O}_{3}$ & $\mathrm{SO}_{4}$ & $\mathrm{C}_{2} \mathrm{O}_{4}$ & $\mathrm{HCO}_{2}$ & $\mathrm{PO}_{4}$ \\
\hline CEF2-F-007 (A) & S-801 & $<100$ & 566 & $<100$ & 114000 & 38000 & 2230 & 2260 & 1520 & $<100$ \\
\hline CEF2-F-007 (B) & S-801 & $<100$ & 573 & $<100$ & 116000 & 37100 & 2260 & 2190 & 1540 & $<100$ \\
\hline CEF2-F-010 (A) & S-802 & $<100$ & 584 & $<100$ & 108000 & 38600 & 2260 & 2230 & 1480 & $<100$ \\
\hline CEF2-F-010 (B) & S-802 & $<100$ & 584 & $<100$ & 108000 & 38600 & 2280 & 2260 & 1480 & $<100$ \\
\hline CEF2-F-013 (A) & S-803 & $<100$ & 516 & $<100$ & 99200 & 35200 & 1930 & 1160 & 2500 & $<100$ \\
\hline CEF2-F-013 (B) & S-803 & $<100$ & 510 & $<100$ & 100000 & 35500 & 1900 & 1120 & 2460 & $<100$ \\
\hline CEF2-F-015 (A) & S-804 & $<100$ & 528 & $<100$ & 100000 & 37800 & 2010 & 1100 & 2590 & $<100$ \\
\hline CEF2-F-015 (B) & S-804 & $<100$ & 508 & $<100$ & 100000 & 38400 & 2000 & 1090 & 2600 & $<100$ \\
\hline CEF2-F-027 (A) & S-814 & $<100$ & 476 & $<100$ & 86300 & 43100 & 1720 & 1260 & 3340 & $<100$ \\
\hline CEF2-F-027 (B) & S-814 & $<100$ & 470 & $<100$ & 85000 & 42700 & 1740 & 1240 & 3420 & $<100$ \\
\hline CEF2-F-030 (A) & $\mathrm{S}-815$ & $<100$ & 455 & $<100$ & 83900 & 43500 & 1690 & 1220 & 3140 & $<100$ \\
\hline CEF2-F-030 (B) & $\mathrm{S}-815$ & $<100$ & 460 & $<100$ & 84100 & 44200 & 1690 & 1220 & 3280 & $<100$ \\
\hline CEF2-F-038 (A) & S-888 & $<100$ & 461 & $<100$ & 89300 & 35700 & 1640 & 1480 & 3040 & $<100$ \\
\hline CEF2-F-038 (B) & S-888 & $<100$ & 462 & $<100$ & 90300 & 35900 & 1650 & 1470 & 3050 & $<100$ \\
\hline CEF2-F-039 (A) & S-889 & $<100$ & 479 & $<100$ & 93100 & 36200 & 1710 & 1540 & 3120 & $<100$ \\
\hline CEF2-F-039 (B) & S-889 & $<100$ & 486 & $<100$ & 93100 & 37600 & 1710 & 1520 & 3050 & $<100$ \\
\hline CEF2-F-041 (A) & S-823 & $<100$ & 525 & $<100$ & 99700 & 43400 & 1720 & 1420 & 3080 & $<100$ \\
\hline CEF2-F-041 (B) & $\mathrm{S}-823$ & $<100$ & 491 & $<100$ & 101000 & 43700 & 1950 & 1430 & 3040 & $<100$ \\
\hline CEF2-F-042 (A) & S-824 & $<100$ & 520 & $<100$ & 99900 & 43300 & 1780 & 1380 & 3180 & $<100$ \\
\hline CEF2-F-042 (B) & S-824 & $<100$ & 523 & $<100$ & 100000 & 43200 & 1770 & 1390 & 3050 & $<100$ \\
\hline CEF2-F-044 (A) & S-825 & $<100$ & 564 & $<100$ & 106000 & 38000 & 1530 & 2010 & 1280 & $<100$ \\
\hline CEF2-F-044 (B) & $\mathrm{S}-825$ & $<100$ & 500 & $<100$ & 103000 & 36000 & 1520 & 2000 & 1380 & $<100$ \\
\hline CEF2-F-047 (A) & S-826 & $<100$ & 497 & $<100$ & 97000 & 43000 & 1710 & 1380 & 3050 & $<100$ \\
\hline CEF2-F-047 (B) & S-826 & $<100$ & 520 & $<100$ & 97100 & 43000 & 1650 & 1360 & 3110 & $<100$ \\
\hline
\end{tabular}


Table A-11. Feed Solids Data, Density and pH

\begin{tabular}{|c|c|c|c|c|c|c|c|c|}
\hline Sample & Lab ID & Total Solids & $\begin{array}{l}\text { Ins oluble } \\
\text { Solids }\end{array}$ & $\begin{array}{c}\text { Wt \% } \\
\text { Calcined }\end{array}$ & $\begin{array}{c}\text { Soluble } \\
\text { Solids }\end{array}$ & pH & $\begin{array}{l}\text { Density } \\
\left(\mathrm{g} / \mathrm{cm}^{3}\right)\end{array}$ & $\begin{array}{c}\text { Supe rnate Density } \\
\left(\mathrm{g} / \mathrm{cm}^{3}\right)\end{array}$ \\
\hline CEF2-F-007 (A) & S-801 & $46.4 \%$ & $34.4 \%$ & $34.9 \%$ & $12.0 \%$ & \multirow{2}{*}{3.07} & 1.3810 & 1.1372 \\
\hline CEF2-F-007 (B) & S-801 & $46.3 \%$ & $34.3 \%$ & $34.8 \%$ & $12.0 \%$ & & 1.3809 & 1.1373 \\
\hline CEF2-F-010 (A) & S-802 & $45.3 \%$ & $33.6 \%$ & $34.1 \%$ & $11.8 \%$ & \multirow{2}{*}{3.60} & 1.3574 & 1.1319 \\
\hline CEF2-F-010 (B) & S-802 & $45.2 \%$ & $33.3 \%$ & $34.0 \%$ & $11.9 \%$ & & 1.3573 & 1.1319 \\
\hline CEF2-F-011 (A) & $\mathrm{S}-820$ & $44.1 \%$ & $32.7 \%$ & $34.4 \%$ & $11.4 \%$ & --- & --- & --- \\
\hline CEF2-F-011 (B) & S-820 & $43.9 \%$ & $32.5 \%$ & $34.2 \%$ & $11.4 \%$ & --- & --- & --- \\
\hline CEF2-F-013 (A) & S-803 & $42.8 \%$ & $30.6 \%$ & $32.6 \%$ & $12.2 \%$ & \multirow{2}{*}{3.86} & 1.3343 & 1.1257 \\
\hline CEF2-F-013 (B) & $\mathrm{S}-803$ & $42.6 \%$ & $30.3 \%$ & $32.3 \%$ & $12.3 \%$ & & 1.3346 & 1.1250 \\
\hline CEF2-F-015 (A) & S-804 & $41.5 \%$ & $28.7 \%$ & $30.9 \%$ & $12.8 \%$ & \multirow{2}{*}{3.78} & 1.3398 & 1.1282 \\
\hline CEF2-F-015 (B) & S-804 & $41.9 \%$ & $29.2 \%$ & $31.3 \%$ & $12.7 \%$ & & 1.3400 & 1.1282 \\
\hline CEF2-F-018 (A) & S-821 & $44.2 \%$ & $32.4 \%$ & $34.0 \%$ & $11.8 \%$ & --- & --- & --- \\
\hline CEF2-F-018 (B) & S-821 & $45.0 \%$ & $33.3 \%$ & $34.3 \%$ & $11.6 \%$ & --- & --- & --- \\
\hline CEF2-F-023 (A) & S-822 & $43.0 \%$ & $30.9 \%$ & $32.7 \%$ & $12.1 \%$ & --- & --- & --- \\
\hline CEF2-F-023 (B) & S-822 & $42.4 \%$ & $30.2 \%$ & $31.9 \%$ & $12.2 \%$ & --- & --- & --- \\
\hline CEF2-F-027 (A) & S-814 & $42.8 \%$ & $31.5 \%$ & $33.5 \%$ & $11.3 \%$ & \multirow{2}{*}{3.64} & 1.3154 & 1.1153 \\
\hline CEF2-F-027 (B) & S-814 & $42.3 \%$ & $31.0 \%$ & $33.0 \%$ & $11.4 \%$ & & 1.3154 & 1.1153 \\
\hline CEF2-F-030 (A) & S-815 & $41.2 \%$ & $29.9 \%$ & $32.0 \%$ & $11.4 \%$ & \multirow{2}{*}{3.67} & 1.3005 & 1.1149 \\
\hline CEF2-F-030 (B) & S-815 & $41.5 \%$ & $30.2 \%$ & $32.3 \%$ & $11.3 \%$ & & 1.3009 & 1.1149 \\
\hline CEF2-F-038 (A) & S-888 & $43.6 \%$ & $31.7 \%$ & $33.1 \%$ & $11.9 \%$ & \multirow{2}{*}{3.62} & 1.3234 & 1.1207 \\
\hline CEF2-F-038 (B) & S-888 & $43.6 \%$ & $31.7 \%$ & $33.1 \%$ & $11.9 \%$ & & 1.3200 & 1.1208 \\
\hline CEF2-F-039 (A) & S-889 & $44.3 \%$ & $30.9 \%$ & $33.9 \%$ & $13.5 \%$ & \multirow{2}{*}{3.73} & 1.3526 & 1.1247 \\
\hline CEF2-F-039 (B) & S-889 & $44.4 \%$ & $32.4 \%$ & $34.0 \%$ & $12.1 \%$ & & 1.3590 & 1.1247 \\
\hline CEF2-F-041 (A) & S-823 & $41.7 \%$ & $27.9 \%$ & $30.8 \%$ & $13.7 \%$ & \multirow{2}{*}{3.59} & 1.3283 & 1.1342 \\
\hline CEF2-F-041 (B) & S-823 & $41.7 \%$ & $27.9 \%$ & $30.8 \%$ & $13.7 \%$ & & 1.3283 & 1.1341 \\
\hline CEF2-F-042 (A) & $\mathrm{S}-824$ & $44.6 \%$ & $31.9 \%$ & $34.4 \%$ & $12.7 \%$ & \multirow{2}{*}{3.64} & 1.3614 & 1.1328 \\
\hline CEF2-F-042 (B) & S-824 & $44.6 \%$ & $31.7 \%$ & $34.3 \%$ & $12.9 \%$ & & 1.3615 & 1.1328 \\
\hline CEF2-F-044 (A) & S-825 & $45.3 \%$ & $33.4 \%$ & $34.1 \%$ & $11.9 \%$ & \multirow{2}{*}{2.97} & 1.3659 & 1.1320 \\
\hline CEF2-F-044 (B) & S-825 & $45.3 \%$ & $33.5 \%$ & $34.0 \%$ & $11.8 \%$ & & 1.3659 & 1.1320 \\
\hline CEF2-F-047 (A) & S-826 & $42.7 \%$ & $30.3 \%$ & $32.0 \%$ & $12.5 \%$ & \multirow{2}{*}{3.63} & 1.3265 & 1.1310 \\
\hline CEF2-F-047 (B) & S-826 & $42.8 \%$ & $29.8 \%$ & $32.1 \%$ & $13.0 \%$ & & 1.3264 & 1.1310 \\
\hline
\end{tabular}


Table A-12. Feed TOC

\begin{tabular}{cc}
\hline Sample ID & $\begin{array}{c}\text { Average TOC } \\
\text { (ppm) }\end{array}$ \\
\hline CEF2-F-007 & 17,211 \\
\hline CEF2-F-008 & 17,317 \\
\hline CEF2-F-009 & 18,298 \\
\hline CEF2-F-010 & 18,593 \\
\hline CEF2-F-013 & 16,169 \\
\hline CEF2-F-015 & 17,160 \\
\hline CEF2-F-018 & 16,274 \\
\hline CEF2-F-023 & 15,193 \\
\hline CEF2-F-027 & 14,744 \\
\hline CEF2-F-030 & 13,452 \\
\hline CEF2-F-038 & 16,730 \\
\hline CEF2-F-039 & 17,139 \\
\hline CEF2-F-041 & 18,141 \\
\hline CEF2-F-042-1 & 16,676 \\
\hline CEF2-F-042-2 & 18,783 \\
\hline CEF2-F-044 & 16,320 \\
\hline CEF2-F-047-1 & 16,449 \\
\hline CEF2-F-047-2 & 16,627 \\
\hline
\end{tabular}


Table A-13. Sealed Crucible REDOX Results

\begin{tabular}{|c|c|c|c|c|c|c|}
\hline Sample ID & Lab ID & $\mathrm{Fe}^{2+}$ & $\mathrm{Fe}^{3+}$ & $\sum \mathbf{F e}$ & $\mathrm{Fe}^{2+} / \mathrm{Fe}^{3+}$ & $\mathrm{Fe}^{2+} / \sum \mathrm{Fe}$ \\
\hline EA & EA & 0.082 & 0.372 & 0.454 & 0.220 & 0.181 \\
\hline CEF2-F-008-1 (A) & S-990 & 0.085 & 0.218 & 0.303 & 0.390 & 0.281 \\
\hline CEF2-F-008-1 (B) & S-990 & 0.084 & 0.220 & 0.304 & 0.382 & 0.276 \\
\hline CEF2-F-008-2 (A) & S-991 & 0.121 & 0.281 & 0.402 & 0.431 & 0.301 \\
\hline CEF2-F-008-2 (B) & S-991 & 0.123 & 0.280 & 0.403 & 0.439 & 0.305 \\
\hline CEF2-F-008-3 (A) & S-992 & 0.107 & 0.258 & 0.365 & 0.415 & 0.293 \\
\hline CEF2-F-008-3 (B) & S-992 & 0.107 & 0.259 & 0.366 & 0.413 & 0.292 \\
\hline CEF2-F-009-1 (A) & S-993 & 0.080 & 0.296 & 0.376 & 0.270 & 0.213 \\
\hline CEF2-F-009-1 (B) & S-993 & 0.080 & 0.296 & 0.376 & 0.270 & 0.213 \\
\hline CEF2-F-014-1 (A) & S-994 & 0.089 & 0.303 & 0.392 & 0.294 & 0.227 \\
\hline CEF2-F-014-1 (B) & S-994 & 0.090 & 0.302 & 0.392 & 0.298 & 0.230 \\
\hline CEF2-F-014-2 (A) & S-995 & 0.087 & 0.274 & 0.361 & 0.318 & 0.241 \\
\hline CEF2-F-014-2 (B) & S-995 & 0.088 & 0.270 & 0.358 & 0.326 & 0.246 \\
\hline CEF2-F-014-3 (A) & S-996 & 0.084 & 0.253 & 0.337 & 0.332 & 0.249 \\
\hline CEF2-F-014-3 (B) & S-996 & 0.085 & 0.251 & 0.336 & 0.339 & 0.253 \\
\hline CEF2-F-019-1 (A) & S-997 & 0.097 & 0.263 & 0.360 & 0.369 & 0.269 \\
\hline CEF2-F-019-1 (B) & S-997 & 0.097 & 0.265 & 0.362 & 0.366 & 0.268 \\
\hline EA & EA & 0.079 & 0.361 & 0.440 & 0.219 & 0.180 \\
\hline CEF2-F-041-1 (A) & S-1029 & 0.199 & 0.268 & 0.467 & 0.743 & 0.426 \\
\hline CEF2-F-041-1 (B) & S-1029 & 0.201 & 0.267 & 0.468 & 0.753 & 0.429 \\
\hline CEF2-F-041-2 (A) & S-1030 & 0.142 & 0.202 & 0.344 & 0.703 & 0.413 \\
\hline CEF2-F-041-2 (B) & S-1030 & 0.142 & 0.202 & 0.344 & 0.703 & 0.413 \\
\hline CEF2-F-042-1 (A) & S-1031 & 0.151 & 0.201 & 0.352 & 0.751 & 0.429 \\
\hline CEF2-F-042-1 (B) & S-1031 & 0.151 & 0.202 & 0.353 & 0.748 & 0.428 \\
\hline CEF2-F-042-2 (A) & S-1032 & 0.207 & 0.218 & 0.425 & 0.950 & 0.487 \\
\hline CEF2-F-042-2 (B) & S-1032 & 0.208 & 0.216 & 0.424 & 0.963 & 0.491 \\
\hline
\end{tabular}


Table A-14. Quartz Crucible REDOX Results (open-top vessel under flowing argon)

\begin{tabular}{ccccccc}
\hline Sample ID & Lab ID & $\mathbf{F e}^{2+}$ & $\mathbf{F e}^{\mathbf{3 +}}$ & $\sum \mathbf{F e}$ & $\mathbf{F e}^{2+} / \mathbf{F e}^{3+}$ & $\mathbf{F e}^{2+} / \sum \mathbf{F e}$ \\
\hline EA & EA & 0.079 & 0.361 & 0.440 & 0.219 & 0.180 \\
\hline CEF2-F-014-1 (A) & S-1289 & 0.110 & 0.314 & 0.424 & 0.350 & 0.259 \\
\hline CEF2-F-014-1 (B) & S-1289 & 0.110 & 0.314 & 0.424 & 0.350 & 0.259 \\
\hline CEF2-F-014-2 (A) & S-1290 & 0.101 & 0.260 & 0.361 & 0.388 & 0.280 \\
\hline CEF2-F-014-2 (B) & S-1290 & 0.101 & 0.259 & 0.360 & 0.390 & 0.281 \\
\hline CEF2-F-041-1 (A) & S-1291 & 0.198 & 0.149 & 0.347 & 1.329 & 0.571 \\
\hline CEF2-F-041-1 (B) & S-1291 & 0.196 & 0.151 & 0.347 & 1.298 & 0.565 \\
\hline CEF2-F-041-2 (A) & S-1292 & 0.200 & 0.154 & 0.354 & 1.299 & 0.565 \\
\hline CEF2-F-041-2 (B) & S-1292 & 0.200 & 0.155 & 0.355 & 1.290 & 0.563 \\
\hline
\end{tabular}


Table A-15. Condensate Sample Summary Set 1

\begin{tabular}{|c|c|c|c|c|c|c|c|c|}
\hline Sample ID & Lab ID & $\begin{array}{c}\text { Collection } \\
\text { Date }\end{array}$ & $\begin{array}{l}\text { Collection } \\
\text { Time }\end{array}$ & Condition & Test & $\begin{array}{c}\text { Feed } \\
\text { Stoichoimetry }\end{array}$ & $\begin{array}{c}\text { Total Solids } \\
\text { Target }\end{array}$ & $\begin{array}{r}\text { Antifoam } \\
\text { Target }\end{array}$ \\
\hline CEF2-C-035 & S829 & $2 / 26 / 2014$ & $16: 25$ & bubbled & steady state & $125 \%$ & $49.2 \%$ as received & nominal \\
\hline CEF2-C-036 & S830 & $2 / 26 / 2014$ & $17: 25$ & bubbled & steady state & $125 \%$ & $45 \%$ & nominal \\
\hline CEF2-C-040 & S831 & $2 / 26 / 2014$ & $21: 25$ & bubbled & steady state & $125 \%$ & $45 \%$ & nominal \\
\hline CEF2-C-049 & S832 & $2 / 27 / 2014$ & $6: 25$ & bubbled & steady state & $125 \%$ & $45 \%$ & nominal \\
\hline CEF2-C-058 & S833 & $2 / 27 / 2014$ & $15: 35$ & bubbled & steady state & $125 \%$ & $45 \%$ & nominal \\
\hline CEF2-C-073 & S966 & $3 / 1 / 2014$ & $14: 30$ & non-bubbled & steady state & $125 \%$ & $45 \%$ & nominal \\
\hline CEF2-C-079 & S805 & $3 / 1 / 2014$ & $20: 30$ & non-bubbled & steady state & $125 \%$ & $45 \%$ & nominal \\
\hline CEF2-C-080 & S806 & $3 / 1 / 2014$ & $21: 30$ & non-bubbled & steady state & $125 \%$ & $45 \%$ & nominal \\
\hline CEF2-C-081 & S807 & $3 / 1 / 2014$ & $22: 30$ & non-bubbled & steady state & $125 \%$ & $45 \%$ & nominal \\
\hline CEF2-C-082 & S808 & $3 / 1 / 2014$ & $23: 30$ & non-bubbled & steady state & $125 \%$ & $45 \%$ & nominal \\
\hline CEF2-C-083 & S809 & $3 / 2 / 2014$ & $0: 30$ & non-bubbled & steady state & $125 \%$ & $45 \%$ & nominal \\
\hline CEF2-C-084 & S810 & $3 / 2 / 2014$ & $1: 30$ & non-bubbled & steady state & $125 \%$ & $45 \%$ & nominal \\
\hline CEF2-C-085 & S811 & $3 / 2 / 2014$ & $2: 30$ & non-bubbled & steady state & $125 \%$ & $45 \%$ & nominal \\
\hline CEF2-C-087 & S812 & $3 / 2 / 2014$ & $4: 30$ & non-bubbled & steady state & $125 \%$ & $45 \%$ & nominal \\
\hline CEF2-C-089 & S834 & $3 / 2 / 2014$ & $6: 30$ & non-bubbled & steady state & $125 \%$ & $45 \%$ & nominal \\
\hline CEF2-C-092 & S835 & $3 / 2 / 2014$ & $9: 30$ & non-bubbled & steady state & $100 \%$ & $45 \%$ & nominal \\
\hline CEF2-C-106 & S836 & $3 / 2 / 2014$ & $23: 30$ & non-bubbled & steady state & $100 \%$ & $45 \%$ & nominal \\
\hline CEF2-C-114 & S837 & $3 / 3 / 2014$ & $7: 30$ & non-bubbled & steady state & $100 \%$ & $45 \%$ & nominal \\
\hline CEF2-C-122 & S838 & $3 / 3 / 2014$ & $15: 30$ & non-bubbled & steady state & $100 \%$ & $45 \%$ & nominal \\
\hline CEF2-C-265 & S813 & $3 / 4 / 2014$ & $9: 40$ & bubbled & steady state & $100 \%$ & $45 \%$ & nominal \\
\hline CEF2-C-140 & S839 & $3 / 4 / 2014$ & $22: 42$ & bubbled & steady state & $100 \%$ & $45 \%$ & nominal \\
\hline CEF2-C-176 & S840 & $3 / 6 / 2014$ & $20: 30$ & bubbled & steady state & $100 \%$ & $45 \%$ & nominal \\
\hline CEF2-C-211 & S841 & $3 / 8 / 2014$ & $8: 00$ & bubbled & steady state & $100 \%$ & $45 \%$ & nominal \\
\hline CEF2-C-213 & S842 & $3 / 8 / 2014$ & $10: 00$ & bubbled & surge & $100 \%$ & $45 \%$ & nominal \\
\hline CEF2-C-236 & S843 & $3 / 9 / 2014$ & $10: 00$ & bubbled & surge & $100 \%$ & $45 \%$ & nominal \\
\hline CEF2-C-242 & S844 & $3 / 10 / 2014$ & $2: 05$ & bubbled & surge & $100 \%$ & $45 \%$ & nominal \\
\hline CEF2-C-257 & S845 & $3 / 10 / 2014$ & 17:05 & bubbled & surge & $100 \%$ & $45 \%$ & nominal \\
\hline
\end{tabular}


Table A-16. Condensate Sample Summary Set 2

\begin{tabular}{|c|c|c|c|c|c|c|c|c|}
\hline Sample ID & Lab ID & $\begin{array}{c}\text { Collection } \\
\text { Date }\end{array}$ & $\begin{array}{c}\text { Collection } \\
\text { Time }\end{array}$ & Condition & Test & $\begin{array}{c}\text { Feed } \\
\text { Stoichoime try }\end{array}$ & $\begin{array}{c}\text { Total Solids } \\
\text { Target }\end{array}$ & $\begin{array}{c}\text { Antifoam } \\
\text { Target }\end{array}$ \\
\hline CEF2-C-260 & S846 & $3 / 10 / 2014$ & $20: 15$ & bubbled & surge & $100 \%$ & $42 \%$ & nominal \\
\hline CEF2-C-261 & S847 & $3 / 11 / 2014$ & $6: 03$ & bubbled & surge & $100 \%$ & $42 \%$ & nominal \\
\hline CEF2-C-266 & S848 & $3 / 11 / 2014$ & $10: 05$ & bubbled & surge & $100 \%$ & $42 \%$ & nominal \\
\hline CEF2-C-270 & S849 & $3 / 11 / 2014$ & $14: 03$ & bubbled & surge & $100 \%$ & $42 \%$ & nominal \\
\hline CEF2-C-274 & $\mathrm{S} 850$ & $3 / 11 / 2014$ & 18:05 & bubbled & surge & $100 \%$ & $42 \%$ & nominal \\
\hline CEF2-C-278 & S851 & $3 / 11 / 2014$ & $22: 05$ & bubbled & surge & $100 \%$ & $42 \%$ & nominal \\
\hline CEF2-C-282 & S852 & $3 / 12 / 2014$ & $2: 05$ & bubbled & surge & $100 \%$ & $42 \%$ & nominal \\
\hline CEF2-C-286 & S853 & $3 / 12 / 2014$ & $6: 05$ & bubbled & surge & $100 \%$ & $42 \%$ & nominal \\
\hline CEF2-C-290 & S854 & $3 / 12 / 2014$ & $10: 05$ & bubbled & surge & $100 \%$ & $42 \%$ & nominal \\
\hline CEF2-C-294 & $\mathrm{S} 855$ & $3 / 12 / 2014$ & $14: 05$ & bubbled & surge & $100 \%$ & $42 \%$ & nominal \\
\hline CEF2-C-298 & S856 & $3 / 12 / 2014$ & 18:05 & bubbled & surge & $100 \%$ & $42 \%$ & nominal \\
\hline CEF2-C-302 & S857 & $3 / 12 / 2014$ & $22: 05$ & bubbled & surge & $100 \%$ & $42 \%$ & nominal \\
\hline CEF2-C-306 & S858 & $3 / 13 / 2014$ & $2: 05$ & bubbled & surge & $100 \%$ & $42 \%$ & nominal \\
\hline CEF2-C-310 & S859 & $3 / 13 / 2014$ & $6: 05$ & bubbled & surge & $100 \%$ & $42 \%$ & nominal \\
\hline CEF2-C-314 & S860 & $3 / 13 / 2014$ & $10: 05$ & bubbled & surge & $100 \%$ & $42 \%$ & nominal \\
\hline CEF2-C-318 & S861 & $3 / 13 / 2014$ & $14: 05$ & bubbled & surge & $100 \%$ & $42 \%$ & nominal \\
\hline CEF2-C-322 & S862 & $3 / 13 / 2014$ & $18: 05$ & bubbled & surge & $100 \%$ & $42 \%$ & nominal \\
\hline CEF2-C-327 & S863 & $3 / 13 / 2014$ & $22: 05$ & bubbled & surge & $100 \%$ & $42 \%$ & nominal \\
\hline CEF2-C-331 & S864 & $3 / 14 / 2014$ & $2: 05$ & bubbled & surge & $100 \%$ & $42 \%$ & nominal \\
\hline CEF2-C-335 & S865 & $3 / 14 / 2014$ & $6: 05$ & bubbled & surge & $100 \%$ & $42 \%$ & nominal \\
\hline CEF2-C-339 & S866 & $3 / 14 / 2014$ & $10: 05$ & bubbled & surge & $100 \%$ & $42 \%$ & nominal \\
\hline CEF2-C-343 & S867 & $3 / 14 / 2014$ & $14: 10$ & bubbled & surge & $100 \%$ & $42 \%$ & nominal \\
\hline CEF2-C-347 & S868 & $3 / 14 / 2014$ & 18:05 & bubbled & surge & $100 \%$ & $42 \%$ & nominal \\
\hline CEF2-C-351 & S869 & $3 / 14 / 2014$ & $22: 05$ & bubbled & surge & $100 \%$ & $42 \%$ & nominal \\
\hline CEF2-C-355 & $\mathrm{S} 870$ & $3 / 15 / 2014$ & $2: 05$ & bubbled & surge & $100 \%$ & $42 \%$ & nominal \\
\hline CEF2-C-359 & S871 & $3 / 15 / 2014$ & $6: 05$ & bubbled & surge & $100 \%$ & $42 \%$ & nominal \\
\hline
\end{tabular}


Table A-17. Condensate Sample Summary Set 3

\begin{tabular}{|c|c|c|c|c|c|c|c|c|}
\hline Sample ID & Lab ID & $\begin{array}{c}\text { Collection } \\
\text { Date }\end{array}$ & $\begin{array}{c}\text { Collection } \\
\text { Time }\end{array}$ & Condition & Test & $\begin{array}{c}\text { Feed } \\
\text { Stoichoime try }\end{array}$ & $\begin{array}{c}\text { Total Solids } \\
\text { Target }\end{array}$ & $\begin{array}{c}\text { Antifoam } \\
\text { Target }\end{array}$ \\
\hline CEF2-C-363 & S872 & $3 / 15 / 2014$ & $10: 05$ & non-bubbled & surge & $100 \%$ & $42 \%$ & nominal \\
\hline CEF2-C-367 & S873 & $3 / 15 / 2014$ & $14: 06$ & non-bubbled & surge & $100 \%$ & $42 \%$ & nominal \\
\hline CEF2-C-371 & S874 & $3 / 15 / 2014$ & 18:00 & non-bubbled & surge & $100 \%$ & $42 \%$ & nominal \\
\hline CEF2-C-376 & S875 & $3 / 15 / 2014$ & $22: 45$ & non-bubbled & surge & $100 \%$ & $42 \%$ & nominal \\
\hline CEF2-C-380 & S876 & $3 / 16 / 2014$ & $2: 45$ & non-bubbled & surge & $100 \%$ & $42 \%$ & nominal \\
\hline CEF2-C-384 & S877 & $3 / 16 / 2014$ & $6: 50$ & non-bubbled & surge & $100 \%$ & $42 \%$ & nominal \\
\hline CEF2-C-388 & S878 & $3 / 16 / 2014$ & $10: 50$ & non-bubbled & surge & $100 \%$ & $42 \%$ & nominal \\
\hline CEF2-C-391 & S879 & $3 / 16 / 2014$ & $13: 50$ & non-bubbled & surge & $100 \%$ & $42 \%$ & nominal \\
\hline CEF2-C-392 & S880 & $3 / 16 / 2014$ & $17: 40$ & non-bubbled & steady state & $100 \%$ & $45 \%$ & $\sim 3 \mathrm{X}$ nominal \\
\hline CEF2-C-401 & S881 & $3 / 17 / 2014$ & $2: 40$ & non-bubbled & steady state & $100 \%$ & $45 \%$ & $\sim 3 \mathrm{X}$ nominal \\
\hline CEF2-C-410 & S882 & $3 / 17 / 2014$ & $11: 40$ & non-bubbled & steady state & $100 \%$ & $45 \%$ & $\sim 3 \mathrm{X}$ nominal \\
\hline CEF2-C-411 & S883 & $3 / 17 / 2014$ & $12: 40$ & non-bubbled & steady state & $100 \%$ & $45 \%$ & $\sim 2 \mathrm{X}$ nominal \\
\hline CEF2-C-416 & S884 & $3 / 17 / 2014$ & $17: 40$ & non-bubbled & steady state & $100 \%$ & $45 \%$ & $\sim 2 \mathrm{X}$ nominal \\
\hline CEF2-C-420 & S885 & $3 / 17 / 2014$ & $21: 40$ & non-bubbled & steady state & $100 \%$ & $45 \%$ & $\sim 2 \mathrm{X}$ nominal \\
\hline CEF2-C-424 & S886 & $3 / 18 / 2014$ & $1: 40$ & non-bubbled & steady state & $100 \%$ & $45 \%$ & $\sim 2 \mathrm{X}$ nominal \\
\hline CEF2-C-428 & S887 & $3 / 18 / 2014$ & $5: 40$ & non-bubbled & steady state & $100 \%$ & $45 \%$ & $\sim 2 \mathrm{X}$ nominal \\
\hline CEF2-C-432 & S890 & $3 / 18 / 2014$ & $9: 40$ & non-bubbled & steady state & $100 \%$ & $45 \%$ & $\sim 2 \mathrm{X}$ nominal \\
\hline CEF2-C-436 & S891 & $3 / 18 / 2014$ & $13: 40$ & non-bubbled & steady state & $100 \%$ & $45 \%$ & $\sim 2 \mathrm{X}$ nominal \\
\hline CEF2-C-440 & S892 & $3 / 18 / 2014$ & $17: 40$ & non-bubbled & steady state & $100 \%$ & $45 \%$ & $\sim 2 \mathrm{X}$ nominal \\
\hline CEF2-C-445 & S893 & $3 / 18 / 2014$ & $22: 40$ & non-bubbled & steady state & $100 \%$ & $45 \%$ & $\sim 2 \mathrm{X}$ nominal \\
\hline CEF2-C-486 & S894 & $3 / 20 / 2014$ & $22: 25$ & & & end of test & & \\
\hline
\end{tabular}


Table A-18. Condensate Cations Set 1A (mg/L)

\begin{tabular}{|c|c|c|c|c|c|c|c|c|c|c|c|}
\hline Sample ID & Lab ID & Al & $\mathbf{B a}$ & $\mathrm{Ca}$ & $\mathrm{Cr}$ & $\mathrm{Cu}$ & $\mathbf{F e}$ & $\mathbf{K}$ & $\mathbf{L i}$ & Mg & Mn \\
\hline CEF2-C-035 & S-829a & 21.8 & $<0.100$ & 8.53 & 0.131 & 0.271 & 8.74 & 2.73 & 2.29 & 0.468 & 11.0 \\
\hline CEF2-C-035 & S-829b & 22.0 & $<0.100$ & 8.54 & 0.135 & 0.421 & 8.87 & 2.73 & 2.29 & 0.483 & 12.2 \\
\hline CEF2-C-036 & S-830a & 23.2 & $<0.100$ & 8.59 & 0.137 & 0.190 & 9.37 & 2.77 & 2.35 & 0.517 & 11.5 \\
\hline CEF2-C-036 & S-830b & 23.1 & $<0.100$ & 8.68 & 0.134 & 0.196 & 9.39 & 2.76 & 2.34 & 0.508 & 11.4 \\
\hline CEF2-C-040 & S-831a & 24.7 & $<0.100$ & 8.80 & 0.138 & 0.252 & 10.4 & 2.80 & 2.41 & 0.632 & 12.7 \\
\hline CEF2-C-040 & S-831b & 24.7 & $<0.100$ & 8.82 & 0.142 & 0.259 & 10.6 & 2.84 & 2.42 & 0.643 & 12.7 \\
\hline CEF2-C-049 & $\mathrm{S}-832 \mathrm{a}$ & 26.3 & $<0.100$ & 8.80 & 0.142 & 0.316 & 12.3 & 2.87 & 2.52 & 0.779 & 14.3 \\
\hline CEF2-C-049 & S-832b & 26.3 & $<0.100$ & 8.88 & 0.144 & 0.313 & 12.3 & 2.90 & 2.51 & 0.786 & 14.3 \\
\hline CEF2-C-058 & S-833a & 26.6 & $<0.100$ & 8.83 & 0.145 & 0.373 & 13.0 & 2.97 & 2.63 & 0.904 & 15.3 \\
\hline CEF2-C-058 & S-833b & 26.6 & $<0.100$ & 8.86 & 0.145 & 0.375 & 13.0 & 2.97 & 2.62 & 0.908 & 15.3 \\
\hline CEF2-C-073 & S-966a & 34.8 & $<0.100$ & 11.3 & 0.155 & 0.767 & $<0.100$ & 3.66 & 3.71 & 1.93 & 21.9 \\
\hline CEF2-C-073 & S-966b & 34.8 & $<0.100$ & 11.4 & 0.158 & 0.768 & $<0.100$ & 3.70 & 3.72 & 1.93 & 21.8 \\
\hline CEF2-C-079 (A) & S-805 & 31.2 & 0.205 & 10.5 & 0.177 & 0.587 & 2.09 & 3.54 & 3.25 & 1.64 & 20.9 \\
\hline CEF2-C-079 (B) & $\mathrm{S}-805$ & 31.2 & 0.205 & 10.5 & 0.178 & 0.595 & 2.10 & 3.55 & 3.24 & 1.63 & 20.8 \\
\hline CEF2-C-080 (A) & S-806 & 31.2 & 0.204 & 10.7 & 0.175 & 0.619 & 2.10 & 3.55 & 3.24 & 1.65 & 20.8 \\
\hline CEF2-C-080 (B) & S-806 & 31.9 & 0.203 & 10.6 & 0.178 & 0.694 & 2.07 & 3.55 & 3.24 & 1.64 & 20.9 \\
\hline CEF2-C-081 (A) & S-807 & 31.2 & 0.202 & 10.5 & 0.181 & 0.579 & 2.01 & 3.53 & 3.24 & 1.63 & 20.9 \\
\hline CEF2-C-081 (B) & S-807 & 31.2 & 0.205 & 10.5 & 0.172 & 0.591 & 2.00 & 3.53 & 3.24 & 1.64 & 20.9 \\
\hline CEF2-C-082 (A) & S-808 & 33.6 & 0.202 & 10.5 & 0.177 & 0.602 & 1.97 & 3.56 & 3.25 & 1.66 & 20.9 \\
\hline CEF2-C-082 (B) & S-808 & 32.9 & 0.201 & 10.6 & 0.178 & 0.637 & 1.95 & 3.58 & 3.26 & 1.66 & 21.1 \\
\hline CEF2-C-083 (A) & S-809 & 29.1 & 0.200 & 9.79 & 0.153 & 0.529 & 1.73 & 3.43 & 3.03 & 1.44 & 19.5 \\
\hline CEF2-C-083 (B) & S-809 & 29.2 & 0.206 & 9.94 & 0.154 & 0.566 & 1.90 & 3.44 & 3.02 & 1.45 & 19.5 \\
\hline CEF2-C-084 (A) & $\mathrm{S}-810$ & 29.7 & 0.855 & 10.2 & 0.152 & 0.707 & 1.76 & 3.44 & 3.09 & 1.51 & 19.9 \\
\hline CEF2-C-084 (B) & S-810 & 29.7 & 0.850 & 10.3 & 0.160 & 0.713 & 1.76 & 3.49 & 3.10 & 1.52 & 20.0 \\
\hline CEF2-C-085 (A) & $\mathrm{S}-811$ & 31.4 & 0.201 & 10.6 & 0.171 & 0.631 & 1.88 & 3.56 & 3.29 & 1.66 & 21.1 \\
\hline CEF2-C-085 (B) & $\mathrm{S}-811$ & 31.4 & 0.204 & 10.5 & 0.176 & 0.637 & 1.93 & 3.53 & 3.26 & 1.65 & 21.0 \\
\hline CEF2-C-087 (A) & $\mathrm{S}-812$ & 31.2 & 0.206 & 10.5 & 0.168 & 0.612 & 1.86 & 3.50 & 3.24 & 1.64 & 20.7 \\
\hline CEF2-C-087 (B) & $\mathrm{S}-812$ & 31.1 & 0.206 & 10.6 & 0.174 & 0.738 & 1.83 & 3.49 & 3.23 & 1.63 & 20.8 \\
\hline
\end{tabular}


Table A-19. Condensate Cations Set 1B (mg/L)

\begin{tabular}{|c|c|c|c|c|c|c|c|c|c|c|c|}
\hline Sample ID & Lab ID & $\mathbf{N a}$ & $\mathbf{N i}$ & $\mathbf{P}$ & $\mathbf{P b}$ & $\mathbf{S}$ & $\mathbf{S i}$ & Sn & $\mathbf{T i}$ & $\mathbf{Z n}$ & $\mathbf{Z r}$ \\
\hline CEF2-C-035 & S-829a & 67.6 & 1.71 & $<1.00$ & $<0.100$ & 20.7 & 8.16 & $<0.100$ & $<0.100$ & $<0.100$ & 0.719 \\
\hline CEF2-C-035 & S-829b & 68.5 & 2.44 & $<1.00$ & $<0.100$ & 21.0 & 8.17 & $<0.100$ & $<0.100$ & $<0.100$ & 0.719 \\
\hline CEF2-C-036 & S-830a & 68.4 & 1.80 & $<1.00$ & $<0.100$ & 20.8 & 8.35 & $<0.100$ & $<0.100$ & $<0.100$ & 0.716 \\
\hline CEF2-C-036 & $\mathrm{S}-830 \mathrm{~b}$ & 68.2 & 1.80 & $<1.00$ & $<0.100$ & 21.3 & 8.38 & $<0.100$ & $<0.100$ & $<0.100$ & 0.716 \\
\hline CEF2-C-040 & S-831a & 71.7 & 2.06 & $<1.00$ & $<0.100$ & 21.4 & 8.41 & $<0.100$ & $<0.100$ & $<0.100$ & 0.717 \\
\hline CEF2-C-040 & $\mathrm{S}-831 \mathrm{~b}$ & 72.4 & 2.05 & $<1.00$ & $<0.100$ & 21.7 & 8.43 & $<0.100$ & $<0.100$ & $<0.100$ & 0.717 \\
\hline CEF2-C-049 & S-832a & 75.2 & 2.47 & $<1.00$ & $<0.100$ & 22.1 & 8.29 & $<0.100$ & $<0.100$ & $<0.100$ & 0.717 \\
\hline CEF2-C-049 & $\mathrm{S}-832 \mathrm{~b}$ & 75.0 & 2.44 & $<1.00$ & $<0.100$ & 22.1 & 8.25 & $<0.100$ & $<0.100$ & $<0.100$ & 0.718 \\
\hline CEF2-C-058 & S-833a & 79.5 & 2.63 & $<1.00$ & $<0.100$ & 23.7 & 8.19 & $<0.100$ & $<0.100$ & $<0.100$ & 0.717 \\
\hline CEF2-C-058 & $\mathrm{S}-833 \mathrm{~b}$ & 78.9 & 2.65 & $<1.00$ & $<0.100$ & 23.8 & 8.26 & $<0.100$ & $<0.100$ & $<0.100$ & 0.718 \\
\hline CEF2-C-073 & S-966a & 104 & 4.04 & $<1.00$ & $<0.100$ & 36.8 & 11.6 & $<0.100$ & $<0.100$ & $<0.100$ & 0.715 \\
\hline CEF2-C-073 & S-966b & 103 & 4.01 & $<1.00$ & $<0.100$ & 36.7 & 11.4 & $<0.100$ & $<0.100$ & $<0.100$ & 0.718 \\
\hline CEF2-C-079 (A) & S-805 & 113 & 3.56 & 0.442 & $<0.100$ & 33.3 & 9.86 & 0.805 & $<0.100$ & $<0.100$ & $<1.00$ \\
\hline CEF2-C-079 (B) & S-805 & 109 & 3.58 & 0.406 & $<0.100$ & 33.4 & 9.40 & 0.811 & $<0.100$ & $<0.100$ & $<1.00$ \\
\hline CEF2-C-080 (A) & S-806 & 110 & 3.58 & 0.456 & $<0.100$ & 33.6 & 9.48 & 0.789 & $<0.100$ & $<0.100$ & $<1.00$ \\
\hline CEF2-C-080 (B) & S-806 & 112 & 3.60 & 0.444 & $<0.100$ & 33.2 & 9.62 & 0.824 & $<0.100$ & $<0.100$ & $<1.00$ \\
\hline CEF2-C-081 (A) & S-807 & 112 & 3.57 & 0.421 & $<0.100$ & 33.2 & 9.77 & 0.787 & $<0.100$ & $<0.100$ & $<1.00$ \\
\hline CEF2-C-081 (B) & S-807 & 109 & 3.60 & 0.429 & $<0.100$ & 33.4 & 9.55 & 0.811 & $<0.100$ & $<0.100$ & $<1.00$ \\
\hline CEF2-C-082 (A) & S-808 & 110 & 3.61 & 0.421 & $<0.100$ & 33.5 & 9.29 & 0.823 & $<0.100$ & $<0.100$ & $<1.00$ \\
\hline CEF2-C-082 (B) & S-808 & 111 & 3.59 & 0.460 & $<0.100$ & 33.1 & 9.63 & 0.819 & $<0.100$ & $<0.100$ & $<1.00$ \\
\hline CEF2-C-083 (A) & S-809 & 111 & 3.29 & 0.425 & $<0.100$ & 30.7 & 9.62 & 0.782 & $<0.100$ & $<0.100$ & $<1.00$ \\
\hline CEF2-C-083 (B) & S-809 & 110 & 3.32 & 0.484 & $<0.100$ & 31.1 & 9.39 & 0.814 & $<0.100$ & $<0.100$ & $<1.00$ \\
\hline CEF2-C-084 (A) & S-810 & 110 & 3.37 & 0.443 & $<0.100$ & 31.2 & 9.34 & 0.800 & $<0.100$ & $<0.100$ & $<1.00$ \\
\hline CEF2-C-084 (B) & S-810 & 111 & 3.38 & 0.437 & $<0.100$ & 31.7 & 9.59 & 0.816 & $<0.100$ & $<0.100$ & $<1.00$ \\
\hline CEF2-C-085 (A) & S-811 & 111 & 3.60 & 0.441 & $<0.100$ & 33.3 & 9.22 & 0.798 & $<0.100$ & $<0.100$ & $<1.00$ \\
\hline CEF2-C-085 (B) & S-811 & 113 & 3.58 & 0.380 & $<0.100$ & 32.9 & 9.50 & 0.786 & $<0.100$ & $<0.100$ & $<1.00$ \\
\hline CEF2-C-087 (A) & S-812 & 111 & 3.56 & 0.418 & $<0.100$ & 32.7 & 9.24 & 0.810 & $<0.100$ & $<0.100$ & $<1.00$ \\
\hline CEF2-C-087 (B) & S-812 & 110 & 3.52 & 0.428 & $<0.100$ & 32.3 & 9.09 & 0.806 & $<0.100$ & $<0.100$ & $<1.00$ \\
\hline
\end{tabular}


Table A-20. Condensate Cations Set 2A (mg/L)

\begin{tabular}{|c|c|c|c|c|c|c|c|c|c|c|c|}
\hline Sample ID & Lab ID & Al & $\mathbf{B a}$ & $\mathbf{C a}$ & $\mathrm{Cr}$ & $\mathbf{C u}$ & $\mathbf{F e}$ & $\mathbf{K}$ & $\mathbf{L i}$ & Mg & Mn \\
\hline CEF2-C-089 & S-834a & 33.0 & $<0.100$ & 10.8 & 0.145 & 0.735 & 1.79 & 3.51 & 3.43 & 1.63 & 19.6 \\
\hline CEF2-C-089 & S-834b & 33.1 & $<0.100$ & 10.9 & 0.143 & 0.737 & 1.77 & 3.55 & 3.46 & 1.64 & 19.7 \\
\hline CEF2-C-092 & S-835a & 33.3 & $<0.100$ & 10.9 & 0.151 & 0.722 & 1.77 & 3.70 & 3.46 & 1.64 & 19.7 \\
\hline CEF2-C-092 & S-835b & 33.2 & $<0.100$ & 10.9 & 0.149 & 0.727 & 1.78 & 3.68 & 3.46 & 1.65 & 19.7 \\
\hline CEF2-C-106 & S-836a & 32.2 & $<0.100$ & 10.4 & 0.157 & 0.713 & 3.73 & 3.43 & 3.29 & 1.54 & 19.2 \\
\hline CEF2-C-106 & S-836b & 32.1 & $<0.100$ & 10.4 & 0.154 & 0.768 & 3.76 & 3.44 & 3.26 & 1.54 & 19.2 \\
\hline CEF2-C-114 & S-837a & 30.0 & $<0.100$ & 9.80 & 0.184 & 0.396 & 12.4 & 3.04 & 2.75 & 1.10 & 16.8 \\
\hline CEF2-C-114 & S-837b & 29.9 & $<0.100$ & 9.89 & 0.184 & 0.410 & 12.5 & 3.03 & 2.75 & 1.10 & 16.8 \\
\hline CEF2-C-122 & S-838a & 32.9 & $<0.100$ & 10.4 & 0.172 & 0.784 & 5.04 & 3.46 & 3.34 & 1.62 & 19.8 \\
\hline CEF2-C-122 & S- $838 b$ & 32.9 & $<0.100$ & 10.6 & 0.171 & 0.793 & 5.07 & 3.46 & 3.33 & 1.62 & 19.9 \\
\hline CEF2-C-265 (A) & $\mathrm{S}-813$ & 34.0 & 0.672 & 11.3 & 0.244 & 1.099 & 6.22 & 3.67 & 3.44 & 1.96 & 22.4 \\
\hline CEF2-C-265 (B) & S-813 & 33.8 & 0.675 & 11.3 & 0.264 & 1.115 & 5.95 & 3.66 & 3.42 & 1.95 & 22.4 \\
\hline CEF2-C-140 & S-839a & 37.1 & $<0.100$ & 12.0 & 0.173 & 1.03 & $<0.100$ & 3.92 & 3.99 & 2.21 & 22.9 \\
\hline CEF2-C-140 & S-839b & 37.3 & $<0.100$ & 12.0 & 0.178 & 0.991 & $<0.100$ & 3.92 & 3.99 & 2.21 & 23.0 \\
\hline CEF2-C-176 & S-840a & 37.5 & $<0.100$ & 12.1 & 0.147 & 1.18 & 3.06 & 4.09 & 4.13 & 2.42 & 23.4 \\
\hline CEF2-C-176 & $\mathrm{S}-840 \mathrm{~b}$ & 37.5 & $<0.100$ & 12.2 & 0.148 & 1.18 & 2.86 & 4.11 & 4.16 & 2.43 & 23.5 \\
\hline CEF2-C-211 & S-841a & 37.4 & $<0.100$ & 10.9 & 0.151 & 1.09 & 10.8 & 3.86 & 3.95 & 2.30 & 23.2 \\
\hline CEF2-C-211 & S-841b & 37.3 & $<0.100$ & 11.0 & 0.151 & 1.11 & 10.6 & 3.85 & 3.94 & 2.28 & 23.1 \\
\hline CEF2-C-213 & S-842a & 37.7 & $<0.100$ & 10.9 & 0.158 & 1.07 & 11.6 & 3.83 & 3.93 & 2.27 & 23.1 \\
\hline CEF2-C-213 & S-842b & 37.8 & $<0.100$ & 10.9 & 0.163 & 1.12 & 11.8 & 3.86 & 3.94 & 2.29 & 23.3 \\
\hline CEF2-C-236 & S-843a & 49.1 & $<0.100$ & 12.0 & 0.217 & 1.11 & 19.8 & 4.06 & 4.33 & 2.49 & 27.0 \\
\hline CEF2-C-236 & $\mathrm{S}-843 \mathrm{~b}$ & 49.2 & 0.101 & 12.0 & 0.220 & 1.12 & 19.5 & 4.07 & 4.34 & 2.50 & 27.0 \\
\hline CEF2-C-242 & S-844a & 53.0 & 0.105 & 12.5 & 0.249 & 1.21 & 21.4 & 4.20 & 4.58 & 2.66 & 28.5 \\
\hline CEF2-C-242 & S-844b & 53.0 & 0.109 & 12.6 & 0.246 & 1.21 & 21.2 & 4.21 & 4.58 & 2.65 & 28.5 \\
\hline CEF2-C-257 & S-845a & 53.7 & 0.140 & 12.9 & 0.254 & 1.24 & 22.1 & 4.26 & 4.76 & 2.64 & 29.1 \\
\hline CEF2-C-257 & S- $845 b$ & 53.7 & 0.141 & 12.8 & 0.254 & 1.20 & 22.0 & 4.26 & 4.79 & 2.64 & 29.1 \\
\hline CEF2-C-260 & S-846a & 54.3 & 0.142 & 12.8 & 0.263 & 1.28 & 22.1 & 4.27 & 4.78 & 2.65 & 29.2 \\
\hline CEF2-C-260 & S-846b & 54.3 & 0.140 & 12.8 & 0.262 & 1.28 & 22.1 & 4.26 & 4.79 & 2.65 & 29.3 \\
\hline
\end{tabular}


Table A-21. Condensate Cations Set 2B (mg/L)

\begin{tabular}{|c|c|c|c|c|c|c|c|c|c|c|c|}
\hline Sample ID & Lab ID & $\mathbf{N a}$ & $\mathbf{N i}$ & $\mathbf{P}$ & $\mathbf{P b}$ & $\mathbf{S}$ & $\mathbf{S i}$ & Sn & $\mathbf{T i}$ & $\mathbf{Z n}$ & $\mathbf{Z r}$ \\
\hline CEF2-C-089 & S-834a & 103 & 3.44 & $<1.00$ & $<0.100$ & 32.2 & 10.1 & $<0.100$ & $<0.100$ & $<0.100$ & 0.717 \\
\hline CEF2-C-089 & $\mathrm{S}-834 \mathrm{~b}$ & 107 & 3.45 & $<1.00$ & $<0.100$ & 32.4 & 10.2 & $<0.100$ & $<0.100$ & $<0.100$ & 0.718 \\
\hline CEF2-C-092 & $\mathrm{S}-835 \mathrm{a}$ & 106 & 3.47 & $<1.00$ & $<0.100$ & 32.5 & 10.4 & $<0.100$ & $<0.100$ & $<0.100$ & 0.716 \\
\hline CEF2-C-092 & $\mathrm{S}-835 \mathrm{~b}$ & 107 & 3.47 & $<1.00$ & $<0.100$ & 32.4 & 10.4 & $<0.100$ & $<0.100$ & $<0.100$ & 0.716 \\
\hline CEF2-C-106 & S-836a & 107 & 3.33 & $<1.00$ & $<0.100$ & 29.8 & 13.1 & $<0.100$ & $<0.100$ & $<0.100$ & 0.717 \\
\hline CEF2-C-106 & $\mathrm{S}-836 \mathrm{~b}$ & 103 & 3.33 & $<1.00$ & $<0.100$ & 29.2 & 13.0 & $<0.100$ & $<0.100$ & $<0.100$ & 0.718 \\
\hline CEF2-C-114 & S-837a & 83.3 & 2.97 & $<1.00$ & $<0.100$ & 24.4 & 10.6 & $<0.100$ & $<0.100$ & $<0.100$ & 0.718 \\
\hline CEF2-C-114 & $\mathrm{S}-837 \mathrm{~b}$ & 83.1 & 2.96 & $<1.00$ & $<0.100$ & 24.2 & 10.5 & $<0.100$ & $<0.100$ & $<0.100$ & 0.717 \\
\hline CEF2-C-122 & S-838a & 106 & 3.49 & $<1.00$ & $<0.100$ & 30.3 & 13.7 & $<0.100$ & $<0.100$ & $<0.100$ & 0.719 \\
\hline CEF2-C-122 & $\mathrm{S}-838 \mathrm{~b}$ & 105 & 3.49 & $<1.00$ & $<0.100$ & 30.1 & 13.6 & $<0.100$ & $<0.100$ & $<0.100$ & 0.718 \\
\hline CEF2-C-265 (A) & S-813 & 117 & 3.93 & 0.411 & $<0.100$ & 31.9 & 12.6 & 0.839 & $<0.100$ & $<0.100$ & $<1.00$ \\
\hline CEF2-C-265 (B) & S-813 & 120 & 3.91 & 0.440 & $<0.100$ & 32.1 & 12.9 & 0.818 & $<0.100$ & $<0.100$ & $<1.00$ \\
\hline CEF2-C-140 & S-839a & 129 & 4.16 & $<1.00$ & $<0.100$ & 34.9 & 14.5 & $<0.100$ & $<0.100$ & $<0.100$ & 0.716 \\
\hline CEF2-C-140 & $\mathrm{S}-839 \mathrm{~b}$ & 124 & 4.15 & $<1.00$ & $<0.100$ & 34.9 & 14.6 & $<0.100$ & $<0.100$ & $<0.100$ & 0.716 \\
\hline CEF2-C-176 & S-840a & 133 & 4.08 & $<1.00$ & $<0.100$ & 34.4 & 18.2 & $<0.100$ & $<0.100$ & 2.21 & 0.718 \\
\hline CEF2-C-176 & $\mathrm{S}-840 \mathrm{~b}$ & 136 & 4.10 & $<1.00$ & $<0.100$ & 35.0 & 18.3 & $<0.100$ & $<0.100$ & 2.22 & 0.715 \\
\hline CEF2-C-211 & S-841a & 122 & 4.30 & $<1.00$ & $<0.100$ & 29.9 & 12.7 & $<0.100$ & $<0.100$ & 2.93 & 0.718 \\
\hline CEF2-C-211 & S-841b & 122 & 4.30 & $<1.00$ & $<0.100$ & 29.8 & 12.5 & $<0.100$ & $<0.100$ & 2.90 & 0.717 \\
\hline CEF2-C-213 & S-842a & 122 & 4.35 & $<1.00$ & $<0.100$ & 29.3 & 12.5 & $<0.100$ & $<0.100$ & 2.92 & 0.717 \\
\hline CEF2-C-213 & $\mathrm{S}-842 \mathrm{~b}$ & 121 & 4.34 & $<1.00$ & $<0.100$ & 29.7 & 12.4 & $<0.100$ & $<0.100$ & 2.95 & 0.718 \\
\hline CEF2-C-236 & S-843a & 139 & 4.75 & $<1.00$ & $<0.100$ & 26.3 & 16.3 & $<0.100$ & $<0.100$ & 3.05 & 0.715 \\
\hline CEF2-C-236 & $\mathrm{S}-843 \mathrm{~b}$ & 137 & 4.74 & $<1.00$ & $<0.100$ & 26.5 & 16.4 & $<0.100$ & $<0.100$ & 3.05 & 0.717 \\
\hline CEF2-C-242 & S-844a & 144 & 5.03 & $<1.00$ & $<0.100$ & 28.4 & 17.2 & 0.145 & $<0.100$ & 3.32 & 0.716 \\
\hline CEF2-C-242 & S-844b & 144 & 5.05 & $<1.00$ & $<0.100$ & 28.5 & 17.3 & 0.117 & $<0.100$ & 3.35 & 0.715 \\
\hline CEF2-C-257 & $\mathrm{S}-845 \mathrm{a}$ & 147 & 5.00 & $<1.00$ & $<0.100$ & 28.2 & 17.2 & 0.103 & $<0.100$ & 2.98 & 0.716 \\
\hline CEF2-C-257 & $\mathrm{S}-845 \mathrm{~b}$ & 147 & 4.95 & $<1.00$ & $<0.100$ & 28.1 & 17.3 & 0.105 & $<0.100$ & 2.98 & 0.715 \\
\hline CEF2-C-260 & S-846a & 150 & 5.00 & $<1.00$ & $<0.100$ & 27.3 & 17.2 & 0.128 & $<0.100$ & 2.92 & 0.716 \\
\hline CEF2-C-260 & $\mathrm{S}-846 \mathrm{~b}$ & 149 & 4.98 & $<1.00$ & $<0.100$ & 27.6 & 17.2 & 0.114 & $<0.100$ & 2.92 & 0.716 \\
\hline
\end{tabular}


Table A-22. Condensate Cations Set 3A (mg/L)

\begin{tabular}{|c|c|c|c|c|c|c|c|c|c|c|c|}
\hline Sample ID & Lab ID & Al & $\mathbf{B a}$ & $\mathrm{Ca}$ & $\mathrm{Cr}$ & $\mathrm{Cu}$ & $\mathbf{F e}$ & $\mathbf{K}$ & $\mathbf{L i}$ & Mg & Mn \\
\hline CEF2-C-261 & S-847a & 58.3 & 0.136 & 13.5 & 0.296 & 1.38 & 23.0 & 4.48 & 5.03 & 2.80 & 30.7 \\
\hline CEF2-C-261 & $\mathrm{S}-847 \mathrm{~b}$ & 58.3 & 0.141 & 13.6 & 0.289 & 1.69 & 23.1 & 4.47 & 5.03 & 2.77 & 30.5 \\
\hline CEF2-C-266 & $\mathrm{S}-848 \mathrm{a}$ & 58.1 & 0.168 & 13.6 & 0.306 & 1.37 & 23.4 & 4.45 & 5.13 & 2.82 & 30.9 \\
\hline CEF2-C-266 & $\mathrm{S}-848 \mathrm{~b}$ & 58.0 & 0.162 & 13.6 & 0.300 & 1.37 & 23.3 & 4.44 & 5.11 & 2.80 & 30.8 \\
\hline CEF2-C-270 & S-849a & 59.4 & 0.157 & 13.7 & 0.307 & 1.28 & 23.3 & 4.49 & 5.18 & 2.82 & 31.3 \\
\hline CEF2-C-270 & $\mathrm{S}-849 \mathrm{~b}$ & 59.5 & 0.157 & 13.7 & 0.302 & 1.80 & 22.8 & 4.52 & 5.18 & 2.79 & 32.8 \\
\hline CEF2-C-274 & $\mathrm{S}-850 \mathrm{a}$ & 61.0 & 0.161 & 13.9 & 0.320 & 1.30 & 22.8 & 4.52 & 5.28 & 2.84 & 31.7 \\
\hline CEF2-C-274 & $\mathrm{S}-850 \mathrm{~b}$ & 60.9 & 0.152 & 13.9 & 0.321 & 1.30 & 23.1 & 4.50 & 5.28 & 2.84 & 31.5 \\
\hline CEF2-C-278 & S-851a & 61.3 & 0.181 & 14.1 & 0.323 & 1.46 & 22.1 & 4.54 & 5.27 & 2.84 & 31.6 \\
\hline CEF2-C-278 & $\mathrm{S}-851 \mathrm{~b}$ & 61.5 & 0.177 & 14.2 & 0.319 & 1.46 & 21.9 & 4.55 & 5.31 & 2.83 & 31.5 \\
\hline CEF2-C-282 & $\mathrm{S}-852 \mathrm{a}$ & 59.6 & 0.173 & 13.7 & 0.312 & 1.29 & 21.2 & 4.45 & 5.21 & 2.73 & 30.6 \\
\hline CEF2-C-282 & S-852b & 59.3 & 0.173 & 13.7 & 0.310 & 1.28 & 21.2 & 4.67 & 5.18 & 2.71 & 30.4 \\
\hline CEF2-C-286 & $\mathrm{S}-853 \mathrm{a}$ & 61.0 & 0.156 & 13.7 & 0.306 & 1.25 & 20.4 & 4.46 & 5.12 & 2.71 & 30.6 \\
\hline CEF2-C-286 & $\mathrm{S}-853 \mathrm{~b}$ & 61.0 & 0.159 & 13.7 & 0.309 & 1.29 & 20.4 & 4.47 & 5.13 & 2.73 & 30.7 \\
\hline CEF2-C-290 & $\mathrm{S}-854 \mathrm{a}$ & 60.4 & 0.163 & 13.6 & 0.308 & 1.25 & 19.3 & 4.43 & 5.09 & 2.67 & 30.2 \\
\hline CEF2-C-290 & $\mathrm{S}-854 \mathrm{~b}$ & 60.3 & 0.166 & 13.6 & 0.304 & 1.27 & 19.4 & 4.41 & 5.07 & 2.68 & 30.2 \\
\hline CEF2-C-294 & $\mathrm{S}-855 \mathrm{a}$ & 61.2 & 0.170 & 13.6 & 0.303 & 1.23 & 18.4 & 4.45 & 5.08 & 2.64 & 30.0 \\
\hline CEF2-C-294 & $\mathrm{S}-855 \mathrm{~b}$ & 61.0 & 0.173 & 13.7 & 0.303 & 1.32 & 18.4 & 4.43 & 5.06 & 2.63 & 30.0 \\
\hline CEF2-C-298 & S-856a & 61.8 & 0.172 & 13.6 & 0.298 & 1.20 & 17.1 & 4.42 & 5.04 & 2.60 & 29.8 \\
\hline CEF2-C-298 & $\mathrm{S}-856 \mathrm{~b}$ & 61.6 & 0.171 & 13.6 & 0.303 & 1.21 & 17.2 & 4.42 & 5.02 & 2.60 & 29.8 \\
\hline CEF2-C-302 & $\mathrm{S}-857 \mathrm{a}$ & 60.8 & 0.193 & 13.5 & 0.304 & 1.22 & 16.2 & 4.37 & 4.95 & 2.55 & 29.2 \\
\hline CEF2-C-302 & $\mathrm{S}-857 \mathrm{~b}$ & 61.4 & 0.181 & 13.8 & 0.294 & 1.44 & 16.4 & 4.38 & 4.94 & 2.57 & 29.2 \\
\hline CEF2-C-306 & $\mathrm{S}-858 \mathrm{a}$ & 61.6 & 0.179 & 13.8 & 0.300 & 1.23 & 15.7 & 4.44 & 4.96 & 2.56 & 29.3 \\
\hline CEF2-C-306 & $\mathrm{S}-858 \mathrm{~b}$ & 61.8 & 0.181 & 14.0 & 0.303 & 1.25 & 15.6 & 4.44 & 4.98 & 2.58 & 29.4 \\
\hline CEF2-C-310 & S-859a & 62.6 & 0.174 & 13.7 & 0.302 & 1.18 & 14.6 & 4.42 & 4.99 & 2.57 & 29.3 \\
\hline CEF2-C-310 & $\mathrm{S}-859 \mathrm{~b}$ & 62.6 & 0.174 & 13.9 & 0.302 & 1.21 & 14.7 & 4.44 & 5.00 & 2.57 & 29.4 \\
\hline CEF2-C-314 & $\mathrm{S}-860 \mathrm{a}$ & 61.9 & 0.176 & 13.6 & 0.295 & 1.14 & 13.3 & 4.37 & 4.92 & 2.49 & 28.6 \\
\hline CEF2-C-314 & $\mathrm{S}-860 \mathrm{~b}$ & 61.9 & 0.171 & 13.6 & 0.293 & 1.15 & 12.9 & 4.39 & 4.92 & 2.48 & 28.5 \\
\hline
\end{tabular}


Table A-23. Condensate Cations Set 3B (mg/L)

\begin{tabular}{|c|c|c|c|c|c|c|c|c|c|c|c|}
\hline Sample ID & Lab ID & $\mathbf{N a}$ & $\mathbf{N i}$ & $\mathbf{P}$ & $\mathbf{P b}$ & $\mathbf{S}$ & Si & Sn & $\mathbf{T i}$ & $\mathbf{Z n}$ & $\mathbf{Z r}$ \\
\hline CEF2-C-261 & S-847a & 154 & 5.23 & $<1.00$ & $<0.100$ & 28.6 & 18.0 & 0.120 & $<0.100$ & 2.94 & 0.722 \\
\hline CEF2-C-261 & $\mathrm{S}-847 \mathrm{~b}$ & 154 & 5.24 & $<1.00$ & $<0.100$ & 28.4 & 17.9 & 0.115 & $<0.100$ & 2.97 & 0.717 \\
\hline CEF2-C-266 & $\mathrm{S}-848 \mathrm{a}$ & 158 & 5.25 & $<1.00$ & $<0.100$ & 29.3 & 18.7 & 0.143 & $<0.100$ & 2.91 & 0.720 \\
\hline CEF2-C-266 & $\mathrm{S}-848 \mathrm{~b}$ & 158 & 5.22 & $<1.00$ & $<0.100$ & 29.0 & 18.6 & 0.091 & $<0.100$ & 2.88 & 0.718 \\
\hline CEF2-C-270 & $\mathrm{S}-849 \mathrm{a}$ & 157 & 5.29 & $<1.00$ & $<0.100$ & 29.4 & 18.9 & 0.141 & $<0.100$ & 2.78 & 0.715 \\
\hline CEF2-C-270 & $\mathrm{S}-849 \mathrm{~b}$ & 156 & 6.42 & $<1.00$ & $<0.100$ & 28.7 & 18.7 & 0.155 & $<0.100$ & 2.87 & 0.718 \\
\hline CEF2-C-274 & $\mathrm{S}-850 \mathrm{a}$ & 162 & 5.26 & $<1.00$ & $<0.100$ & 28.8 & 19.1 & 0.142 & $<0.100$ & 2.71 & 0.716 \\
\hline CEF2-C-274 & $\mathrm{S}-850 \mathrm{~b}$ & 160 & 5.26 & $<1.00$ & $<0.100$ & 28.8 & 19.1 & 0.142 & $<0.100$ & 2.71 & 0.716 \\
\hline CEF2-C-278 & S-851a & 161 & 5.21 & $<1.00$ & $<0.100$ & 28.8 & 19.1 & 0.143 & $<0.100$ & 2.63 & 0.717 \\
\hline CEF2-C-278 & $\mathrm{S}-851 \mathrm{~b}$ & 162 & 5.24 & $<1.00$ & $<0.100$ & 29.0 & 19.2 & 0.133 & $<0.100$ & 2.61 & 0.716 \\
\hline CEF2-C-282 & S-852a & 156 & 5.03 & $<1.00$ & $<0.100$ & 28.0 & 18.8 & 0.128 & $<0.100$ & 2.52 & 0.717 \\
\hline CEF2-C-282 & $\mathrm{S}-852 \mathrm{~b}$ & 159 & 5.00 & $<1.00$ & $<0.100$ & 27.9 & 18.7 & 0.142 & $<0.100$ & 2.53 & 0.716 \\
\hline CEF2-C-286 & S-853a & 160 & 5.09 & $<1.00$ & $<0.100$ & 27.0 & 19.1 & 0.134 & $<0.100$ & 2.44 & 0.719 \\
\hline CEF2-C-286 & $\mathrm{S}-853 \mathrm{~b}$ & 163 & 5.02 & $<1.00$ & $<0.100$ & 27.1 & 19.3 & 0.135 & $<0.100$ & 2.46 & 0.716 \\
\hline CEF2-C-290 & S-854a & 161 & 4.89 & $<1.00$ & $<0.100$ & 26.6 & 19.0 & 0.110 & $<0.100$ & 2.46 & 0.716 \\
\hline CEF2-C-290 & $\mathrm{S}-854 \mathrm{~b}$ & 159 & 4.86 & $<1.00$ & $<0.100$ & 26.8 & 18.9 & 0.148 & $<0.100$ & 2.47 & 0.717 \\
\hline CEF2-C-294 & $\mathrm{S}-855 \mathrm{a}$ & 159 & 4.84 & $<1.00$ & $<0.100$ & 26.4 & 19.4 & 0.132 & $<0.100$ & 2.47 & 0.716 \\
\hline CEF2-C-294 & $\mathrm{S}-855 \mathrm{~b}$ & 157 & 4.84 & $<1.00$ & $<0.100$ & 25.9 & 19.4 & 0.127 & $<0.100$ & 2.48 & 0.714 \\
\hline CEF2-C-298 & S-856a & 159 & 4.76 & $<1.00$ & $<0.100$ & 25.9 & 19.5 & 0.147 & $<0.100$ & 2.48 & 0.715 \\
\hline CEF2-C-298 & $\mathrm{S}-856 \mathrm{~b}$ & 159 & 4.77 & $<1.00$ & $<0.100$ & 25.8 & 19.5 & 0.133 & $<0.100$ & 2.48 & 0.717 \\
\hline CEF2-C-302 & $\mathrm{S}-857 \mathrm{a}$ & 156 & 4.61 & $<1.00$ & $<0.100$ & 24.8 & 19.4 & 0.149 & $<0.100$ & 2.41 & 0.720 \\
\hline CEF2-C-302 & S-857b & 155 & 4.62 & $<1.00$ & $<0.100$ & 24.9 & 19.4 & 0.154 & $<0.100$ & 2.45 & 0.717 \\
\hline CEF2-C-306 & S-858a & 156 & 4.62 & $<1.00$ & $<0.100$ & 24.7 & 19.6 & 0.131 & $<0.100$ & 2.37 & 0.717 \\
\hline CEF2-C-306 & $\mathrm{S}-858 \mathrm{~b}$ & 157 & 4.65 & $<1.00$ & $<0.100$ & 24.8 & 19.7 & 0.133 & $<0.100$ & 2.40 & 0.716 \\
\hline CEF2-C-310 & S-859a & 156 & 4.63 & $<1.00$ & $<0.100$ & 24.8 & 20.1 & 0.130 & $<0.100$ & 2.28 & 0.715 \\
\hline CEF2-C-310 & S-859b & 157 & 4.68 & $<1.00$ & $<0.100$ & 24.8 & 20.1 & 0.130 & $<0.100$ & 2.28 & 0.716 \\
\hline CEF2-C-314 & S-860a & 160 & 4.48 & $<1.00$ & $<0.100$ & 24.3 & 19.8 & 0.115 & $<0.100$ & 2.16 & 0.716 \\
\hline CEF2-C-314 & S-860b & 160 & 4.46 & $<1.00$ & $<0.100$ & 23.9 & 20.0 & 0.144 & $<0.100$ & 2.15 & 0.716 \\
\hline
\end{tabular}


Table A-24. Condensate Cations Set 4A (mg/L)

\begin{tabular}{|c|c|c|c|c|c|c|c|c|c|c|c|}
\hline Sample ID & Lab ID & Al & $\mathbf{B a}$ & $\mathbf{C a}$ & $\mathrm{Cr}$ & $\mathrm{Cu}$ & $\mathbf{F e}$ & $\mathbf{K}$ & $\mathbf{L i}$ & $\mathbf{M g}$ & Mn \\
\hline CEF2-C-318 & S-861a & 62.7 & 0.177 & 13.7 & 0.297 & 1.19 & 11.8 & 4.46 & 4.96 & 2.49 & 28.6 \\
\hline CEF2-C-318 & $\mathrm{S}-861 \mathrm{~b}$ & 62.6 & 0.178 & 13.8 & 0.295 & 1.25 & 11.7 & 4.46 & 4.95 & 2.49 & 28.5 \\
\hline CEF2-C-322 & $\mathrm{S}-862 \mathrm{~b}$ & 61.0 & 0.185 & 13.3 & 0.277 & 1.11 & 10.5 & 4.36 & 4.82 & 2.41 & 27.7 \\
\hline CEF2-C-327 & S-863a & 61.7 & 0.206 & 13.5 & 0.277 & 1.18 & 9.37 & 4.39 & 4.84 & 2.41 & 27.4 \\
\hline CEF2-C-327 & $\mathrm{S}-863 \mathrm{~b}$ & 61.9 & 0.206 & 13.7 & 0.278 & 1.18 & 9.36 & 4.43 & 4.85 & 2.41 & 27.3 \\
\hline CEF2-C-331 & $\mathrm{S}-864 \mathrm{a}$ & 61.1 & 0.195 & 13.3 & 0.260 & 1.10 & 7.91 & 4.41 & 4.76 & 2.33 & 26.6 \\
\hline CEF2-C-331 & S-864b & 61.0 & 0.196 & 13.3 & 0.261 & 1.11 & 7.92 & 4.36 & 4.76 & 2.33 & 26.6 \\
\hline CEF2-C-335 & $\mathrm{S}-865 \mathrm{a}$ & 61.5 & 0.191 & 13.5 & 0.256 & 1.07 & 6.20 & 4.35 & 4.73 & 2.36 & 26.6 \\
\hline CEF2-C-335 & S-865b & 61.7 & 0.195 & 13.7 & 0.254 & 1.14 & 6.14 & 4.36 & 4.70 & 2.35 & 26.6 \\
\hline CEF2-C-339 & S-866a & 61.6 & 0.210 & 13.8 & 0.266 & 1.08 & 6.40 & 4.47 & 4.80 & 2.37 & 26.3 \\
\hline CEF2-C-339 & S-866b & 61.5 & 0.205 & 13.8 & 0.265 & 1.10 & 6.42 & 4.46 & 4.80 & 2.38 & 26.3 \\
\hline CEF2-C-343 & $\mathrm{S}-867 \mathrm{a}$ & 61.4 & 0.193 & 13.6 & 0.253 & 1.13 & 5.47 & 4.41 & 4.76 & 2.35 & 26.0 \\
\hline CEF2-C-343 & S-867b & 61.4 & 0.197 & 13.7 & 0.257 & 1.42 & 5.62 & 4.45 & 4.77 & 2.35 & 25.9 \\
\hline CEF2-C-347 & S-868a & 62.2 & 0.187 & 13.9 & 0.246 & 1.09 & 4.14 & 4.42 & 4.74 & 2.32 & 25.6 \\
\hline CEF2-C-347 & $\mathrm{S}-868 \mathrm{~b}$ & 62.1 & 0.186 & 14.0 & 0.239 & 1.08 & 4.10 & 4.40 & 4.71 & 2.31 & 25.5 \\
\hline CEF2-C-351 & S-869a & 62.4 & 0.188 & 13.8 & 0.234 & 1.03 & 3.11 & 4.41 & 4.73 & 2.33 & 25.5 \\
\hline CEF2-C-351 & S-869b & 62.3 & 0.185 & 13.9 & 0.237 & 1.03 & 3.09 & 4.44 & 4.73 & 2.34 & 25.6 \\
\hline CEF2-C-355 & S-870a & 61.4 & 0.208 & 13.6 & 0.218 & 1.18 & 2.75 & 4.42 & 4.66 & 2.27 & 24.7 \\
\hline CEF2-C-355 & S-870b & 60.9 & 0.207 & 13.7 & 0.219 & 1.18 & 2.72 & 4.43 & 4.65 & 2.26 & 24.7 \\
\hline CEF2-C-359 & S-871a & 60.9 & 0.204 & 13.5 & 0.207 & 1.00 & 2.10 & 4.39 & 4.59 & 2.22 & 24.3 \\
\hline CEF2-C-359 & S-871b & 60.9 & 0.201 & 13.5 & 0.209 & 1.00 & 2.08 & 4.38 & 4.58 & 2.21 & 24.2 \\
\hline CEF2-C-363 & S-872a & 59.9 & 0.212 & 13.4 & 0.201 & 0.967 & 1.65 & 4.39 & 4.57 & 2.18 & 23.6 \\
\hline CEF2-C-363 & S-872b & 60.1 & 0.209 & 13.5 & 0.199 & 0.975 & 1.66 & 4.42 & 4.55 & 2.18 & 23.6 \\
\hline CEF2-C-367 & S-873a & 59.5 & 0.208 & 13.4 & 0.191 & 0.965 & 1.58 & 4.37 & 4.51 & 2.16 & 23.3 \\
\hline CEF2-C-367 & S-873b & 59.5 & 0.207 & 13.5 & 0.192 & 0.983 & 1.57 & 4.36 & 4.50 & 2.15 & 23.2 \\
\hline
\end{tabular}


Table A-25. Condensate Cations Set 4B (mg/L)

\begin{tabular}{|c|c|c|c|c|c|c|c|c|c|c|c|}
\hline Sample ID & Lab ID & $\mathbf{N a}$ & $\mathbf{N i}$ & $\mathbf{P}$ & $\mathbf{P b}$ & $\mathbf{S}$ & Si & Sn & $\mathbf{T i}$ & Zn & $\mathbf{Z r}$ \\
\hline CEF2-C-318 & S-861a & 161 & 4.42 & $<1.00$ & $<0.100$ & 24.1 & 20.1 & 0.127 & $<0.100$ & 2.12 & 0.716 \\
\hline CEF2-C-318 & $\mathrm{S}-861 \mathrm{~b}$ & 158 & 4.42 & $<1.00$ & $<0.100$ & 23.8 & 19.9 & 0.115 & $<0.100$ & 2.13 & 0.716 \\
\hline CEF2-C-322 & $\mathrm{S}-862 \mathrm{a}$ & 157 & 4.29 & $<1.00$ & $<0.100$ & 23.6 & 20.5 & 0.141 & $<0.100$ & 2.06 & 0.716 \\
\hline CEF2-C-322 & $\mathrm{S}-862 \mathrm{~b}$ & 154 & 4.25 & $<1.00$ & $<0.100$ & 23.6 & 20.5 & 0.132 & $<0.100$ & 2.03 & 0.715 \\
\hline CEF2-C-327 & S-863a & 157 & 4.19 & $<1.00$ & $<0.100$ & 23.1 & 19.8 & 0.112 & $<0.100$ & 1.96 & 0.715 \\
\hline CEF2-C-327 & $\mathrm{S}-863 \mathrm{~b}$ & 157 & 4.17 & $<1.00$ & $<0.100$ & 23.5 & 19.8 & 0.129 & $<0.100$ & 1.95 & 0.715 \\
\hline CEF2-C-331 & S-864a & 156 & 4.06 & $<1.00$ & $<0.100$ & 22.7 & 19.9 & $<0.100$ & $<0.100$ & 1.86 & 0.716 \\
\hline CEF2-C-331 & $\mathrm{S}-864 \mathrm{~b}$ & 158 & 4.07 & $<1.00$ & $<0.100$ & 22.8 & 19.9 & $<0.100$ & $<0.100$ & 1.86 & 0.715 \\
\hline CEF2-C-335 & S-865a & 159 & 4.04 & $<1.00$ & $<0.100$ & 22.5 & 20.1 & 0.110 & $<0.100$ & 1.81 & 0.717 \\
\hline CEF2-C-335 & $\mathrm{S}-865 \mathrm{~b}$ & 157 & 4.01 & $<1.00$ & $<0.100$ & 22.7 & 20.0 & 0.102 & $<0.100$ & 1.81 & 0.717 \\
\hline CEF2-C-339 & S-866a & 161 & 3.97 & $<1.00$ & $<0.100$ & 22.8 & 19.9 & 0.142 & $<0.100$ & 1.86 & 0.719 \\
\hline CEF2-C-339 & S-866b & 162 & 3.99 & $<1.00$ & $<0.100$ & 23.0 & 19.8 & 0.118 & $<0.100$ & 1.87 & 0.716 \\
\hline CEF2-C-343 & $\mathrm{S}-867 \mathrm{a}$ & 158 & 3.92 & $<1.00$ & $<0.100$ & 22.4 & 20.2 & 0.099 & $<0.100$ & 1.99 & 0.716 \\
\hline CEF2-C-343 & S-867b & 159 & 3.92 & $<1.00$ & $<0.100$ & 22.1 & 20.2 & 0.114 & $<0.100$ & 2.02 & 0.715 \\
\hline CEF2-C-347 & S-868a & 162 & 3.82 & $<1.00$ & $<0.100$ & 22.2 & 21.0 & $<0.100$ & $<0.100$ & 1.99 & 0.723 \\
\hline CEF2-C-347 & S-868b & 164 & 3.79 & $<1.00$ & $<0.100$ & 22.5 & 20.9 & $<0.100$ & $<0.100$ & 1.99 & 0.718 \\
\hline CEF2-C-351 & S-869a & 163 & 3.80 & $<1.00$ & $<0.100$ & 22.3 & 20.9 & $<0.100$ & $<0.100$ & 2.04 & 0.715 \\
\hline CEF2-C-351 & S-869b & 159 & 3.82 & $<1.00$ & $<0.100$ & 22.1 & 20.8 & $<0.100$ & $<0.100$ & 2.05 & 0.717 \\
\hline CEF2-C-355 & $\mathrm{S}-870 \mathrm{a}$ & 158 & 3.64 & $<1.00$ & $<0.100$ & 21.7 & 19.9 & $<0.100$ & $<0.100$ & 2.11 & 0.715 \\
\hline CEF2-C-355 & S-870b & 160 & 3.68 & $<1.00$ & $<0.100$ & 21.9 & 19.9 & $<0.100$ & $<0.100$ & 2.11 & 0.716 \\
\hline CEF2-C-359 & S-871a & 160 & 3.60 & $<1.00$ & $<0.100$ & 21.5 & 19.6 & 0.100 & $<0.100$ & 2.15 & 0.714 \\
\hline CEF2-C-359 & S-871b & 158 & 3.53 & $<1.00$ & $<0.100$ & 21.4 & 19.6 & 0.100 & $<0.100$ & 2.14 & 0.716 \\
\hline CEF2-C-363 & S-872a & 160 & 3.43 & $<1.00$ & $<0.100$ & 21.0 & 19.6 & $<0.100$ & $<0.100$ & 2.18 & 0.716 \\
\hline CEF2-C-363 & $\mathrm{S}-872 \mathrm{~b}$ & 161 & 3.46 & $<1.00$ & $<0.100$ & 21.2 & 19.7 & $<0.100$ & $<0.100$ & 2.18 & 0.717 \\
\hline CEF2-C-367 & S-873a & 157 & 3.38 & $<1.00$ & $<0.100$ & 20.7 & 19.1 & $<0.100$ & $<0.100$ & 2.18 & 0.716 \\
\hline CEF2-C-367 & S-873b & 159 & 3.40 & $<1.00$ & $<0.100$ & 20.5 & 19.1 & 0.126 & $<0.100$ & 2.20 & 0.716 \\
\hline CEF2-C-371 & S-874a & 156 & 3.33 & $<1.00$ & $<0.100$ & 20.1 & 18.9 & 0.116 & $<0.100$ & 2.15 & 0.716 \\
\hline CEF2-C-371 & $\mathrm{S}-874 \mathrm{~b}$ & 154 & 3.34 & $<1.00$ & $<0.100$ & 20.6 & 19.0 & 0.112 & $<0.100$ & 2.12 & 0.716 \\
\hline
\end{tabular}


Table A-26. Condensate Cations Set 5A (mg/L)

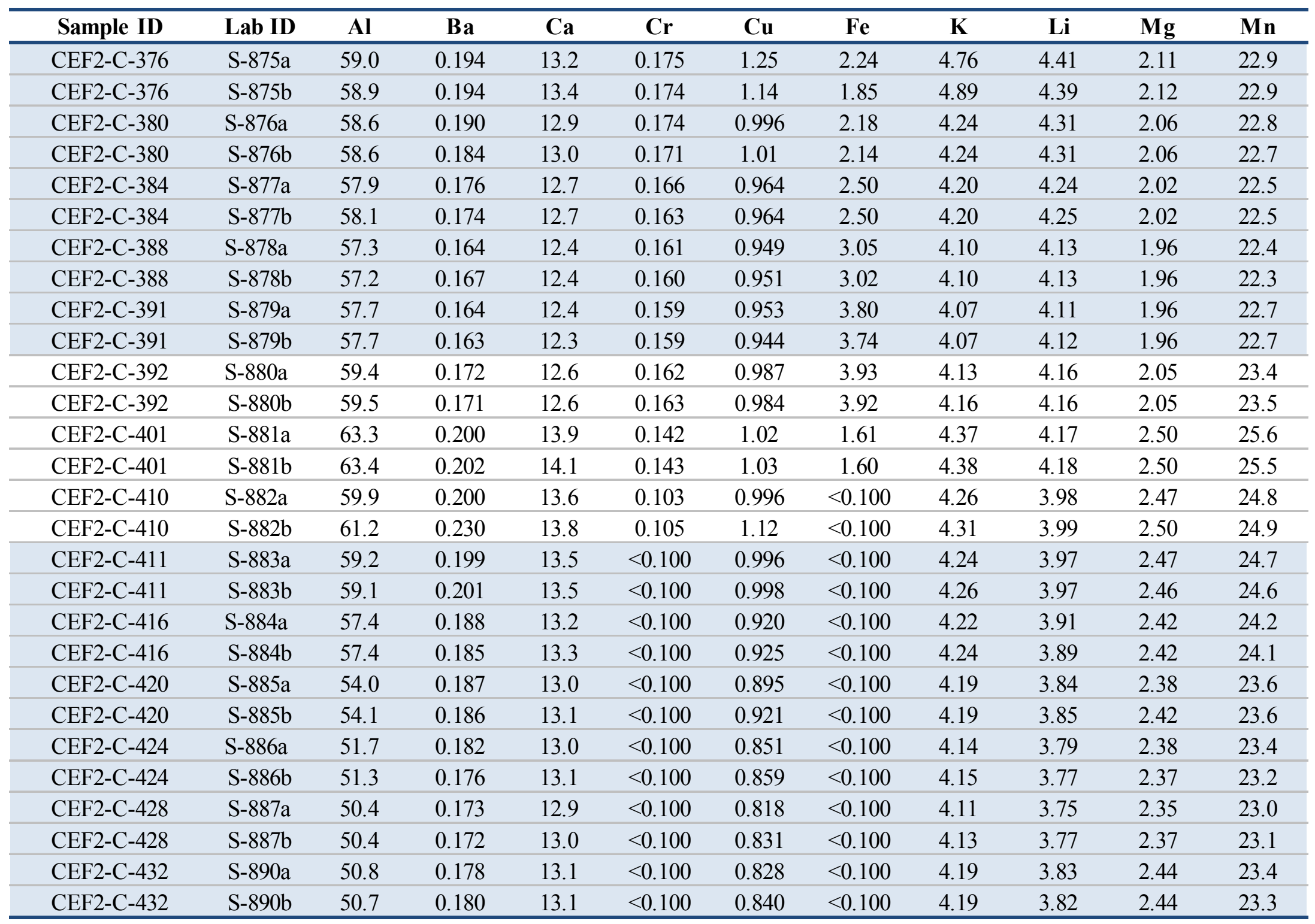


Table A-27. Condensate Cations Set 5B (mg/mL)

\begin{tabular}{|c|c|c|c|c|c|c|c|c|c|c|c|}
\hline Sample ID & Lab ID & $\mathbf{N a}$ & $\mathbf{N i}$ & $\mathbf{P}$ & $\mathbf{P b}$ & $\mathbf{S}$ & $\mathbf{S i}$ & Sn & $\mathbf{T i}$ & $\mathbf{Z n}$ & $\mathbf{Z r}$ \\
\hline CEF2-C-376 & S-875a & 153 & 3.35 & $<1.00$ & $<0.100$ & 19.6 & 18.8 & 0.053 & $<0.100$ & 2.18 & 0.715 \\
\hline CEF2-C-376 & S-875b & 156 & 3.35 & $<1.00$ & $<0.100$ & 19.7 & 18.7 & $<0.100$ & $<0.100$ & 2.19 & 0.714 \\
\hline CEF2-C-380 & S-876a & 150 & 3.31 & $<1.00$ & $<0.100$ & 19.2 & 18.3 & $<0.100$ & $<0.100$ & 1.98 & 0.718 \\
\hline CEF2-C-380 & S-876b & 151 & 3.32 & $<1.00$ & $<0.100$ & 19.2 & 18.3 & $<0.100$ & $<0.100$ & 1.97 & 0.714 \\
\hline CEF2-C-384 & S-877a & 148 & 3.29 & $<1.00$ & $<0.100$ & 18.7 & 18.1 & $<0.100$ & $<0.100$ & 1.93 & 0.715 \\
\hline CEF2-C-384 & $\mathrm{S}-877 \mathrm{~b}$ & 148 & 3.28 & $<1.00$ & $<0.100$ & 18.7 & 18.1 & $<0.100$ & $<0.100$ & 1.92 & 0.716 \\
\hline CEF2-C-388 & S-878a & 143 & 3.26 & $<1.00$ & $<0.100$ & 18.2 & 17.8 & $<0.100$ & $<0.100$ & 1.88 & 0.714 \\
\hline CEF2-C-388 & $\mathrm{S}-878 \mathrm{~b}$ & 143 & 3.25 & $<1.00$ & $<0.100$ & 18.1 & 17.8 & $<0.100$ & $<0.100$ & 1.88 & 0.715 \\
\hline CEF2-C-391 & S-879a & 141 & 3.34 & $<1.00$ & $<0.100$ & 17.9 & 17.8 & $<0.100$ & $<0.100$ & 1.87 & 0.716 \\
\hline CEF2-C-391 & S-879b & 141 & 3.35 & $<1.00$ & $<0.100$ & 18.0 & 17.7 & $<0.100$ & $<0.100$ & 1.86 & 0.716 \\
\hline CEF2-C-392 & S-880a & 144 & 3.50 & $<1.00$ & $<0.100$ & 17.7 & 18.4 & $<0.100$ & $<0.100$ & 1.86 & 0.716 \\
\hline CEF2-C-392 & $\mathrm{S}-880 \mathrm{~b}$ & 144 & 3.50 & $<1.00$ & $<0.100$ & 17.5 & 18.3 & $<0.100$ & $<0.100$ & 1.86 & 0.716 \\
\hline CEF2-C-401 & S-881a & 160 & 3.62 & $<1.00$ & $<0.100$ & 16.8 & 28.5 & $<0.100$ & $<0.100$ & 1.78 & 0.715 \\
\hline CEF2-C-401 & $\mathrm{S}-881 \mathrm{~b}$ & 161 & 3.65 & $<1.00$ & $<0.100$ & 17.1 & 28.6 & $<0.100$ & $<0.100$ & 1.79 & 0.716 \\
\hline CEF2-C-410 & S-882a & 156 & 3.52 & $<1.00$ & $<0.100$ & 15.9 & 45.4 & $<0.100$ & $<0.100$ & 1.71 & 0.716 \\
\hline CEF2-C-410 & $\mathrm{S}-882 \mathrm{~b}$ & 157 & 3.51 & $<1.00$ & $<0.100$ & 15.9 & 46.3 & $<0.100$ & $<0.100$ & 1.75 & 0.721 \\
\hline CEF2-C-411 & S-883a & 157 & 3.46 & $<1.00$ & $<0.100$ & 16.0 & 48.6 & $<0.100$ & $<0.100$ & 1.72 & 0.715 \\
\hline CEF2-C-411 & $\mathrm{S}-883 \mathrm{~b}$ & 158 & 3.46 & $<1.00$ & $<0.100$ & 15.8 & 48.4 & $<0.100$ & $<0.100$ & 1.70 & 0.716 \\
\hline CEF2-C-416 & S-884a & 155 & 3.38 & $<1.00$ & $<0.100$ & 15.4 & 44.9 & $<0.100$ & $<0.100$ & 1.63 & 0.714 \\
\hline CEF2-C-416 & S-884b & 156 & 3.35 & $<1.00$ & $<0.100$ & 15.6 & 44.5 & $<0.100$ & $<0.100$ & 1.62 & 0.716 \\
\hline CEF2-C-420 & S-885a & 155 & 3.29 & $<1.00$ & $<0.100$ & 15.5 & 50.2 & $<0.100$ & $<0.100$ & 1.58 & 0.718 \\
\hline CEF2-C-420 & $\mathrm{S}-885 \mathrm{~b}$ & 154 & 3.30 & $<1.00$ & $<0.100$ & 15.8 & 50.0 & $<0.100$ & $<0.100$ & 1.59 & 0.719 \\
\hline CEF2-C-424 & S-886a & 151 & 3.24 & $<1.00$ & $<0.100$ & 15.8 & 57.1 & $<0.100$ & $<0.100$ & 1.53 & 0.718 \\
\hline CEF2-C-424 & S-886b & 154 & 3.25 & $<1.00$ & $<0.100$ & 15.2 & 55.6 & $<0.100$ & $<0.100$ & 1.52 & 0.717 \\
\hline CEF2-C-428 & S-887a & 154 & 3.18 & $<1.00$ & $<0.100$ & 15.1 & 54.9 & $<0.100$ & $<0.100$ & 1.47 & 0.716 \\
\hline CEF2-C-428 & $\mathrm{S}-887 \mathrm{~b}$ & 154 & 3.21 & $<1.00$ & $<0.100$ & 14.8 & 55.7 & $<0.100$ & $<0.100$ & 1.49 & 0.716 \\
\hline CEF2-C-432 & S-890a & 153 & 3.25 & $<1.00$ & $<0.100$ & 15.6 & 50.0 & $<0.100$ & $<0.100$ & 1.49 & 0.716 \\
\hline CEF2-C-432 & S-890b & 158 & 3.25 & $<1.00$ & $<0.100$ & 15.6 & 49.6 & $<0.100$ & $<0.100$ & 1.50 & 0.717 \\
\hline
\end{tabular}


Table A-28. Condensate Cations Set $6(\mathrm{mg} / \mathrm{L})$

\begin{tabular}{cccccccccccc}
\hline Sample ID & Lab ID & Al & $\mathbf{B a}$ & $\mathbf{C a}$ & $\mathbf{C r}$ & $\mathbf{C u}$ & $\mathbf{F e}$ & $\mathbf{K}$ & $\mathbf{L i}$ & $\mathbf{M g}$ & $\mathbf{M n}$ \\
\hline CEF2-C-436 & S-891a & 49.1 & 0.696 & 49.1 & 1.07 & 0.908 & $<0.100$ & 4.16 & 3.87 & 2.60 & 22.6 \\
\hline CEF2-C-436 & S-891b & 49.1 & 0.208 & 49.1 & $<0.100$ & 0.908 & $<0.100$ & 4.16 & 3.87 & 2.60 & 24.5 \\
\hline CEF2-C-440 & S-892a & 48.9 & 0.209 & 13.3 & $<0.100$ & 0.803 & $<0.100$ & 4.25 & 3.96 & 2.69 & 24.9 \\
\hline CEF2-C-440 & S-892b & 48.7 & 0.214 & 13.3 & $<0.100$ & 0.886 & $<0.100$ & 4.25 & 3.94 & 2.67 & 24.8 \\
\hline CEF2-C-445 & S-893a & 48.8 & 0.216 & 13.6 & $<0.100$ & 0.827 & $<0.100$ & 4.27 & 4.03 & 2.78 & 25.3 \\
\hline CEF2-C-445 & S-893b & 48.7 & 0.217 & 13.7 & $<0.100$ & 0.944 & $<0.100$ & 4.27 & 4.02 & 2.77 & 25.3 \\
\hline CEF2-C-486 & S-894a & 40.6 & 0.177 & 13.2 & $<0.100$ & 0.711 & $<0.100$ & 4.15 & 3.70 & 2.72 & 23.3 \\
\hline CEF2-C-486 & S-894b & 40.5 & 0.178 & 13.2 & $<0.100$ & 0.807 & $<0.100$ & 4.15 & 3.70 & 2.73 & 23.3 \\
\hline & & & & & & & & & & & \\
\hline Sample ID & Lab ID & Na & Ni & P & Pb & S & Si & Sn & Ti & $\mathbf{Z n}$ & $\mathbf{Z r}$ \\
\hline CEF2-C-436 & S-891a & 160 & 3.43 & $<1.00$ & $<0.100$ & 16.6 & 41.1 & $<0.100$ & $<0.100$ & 1.59 & 0.717 \\
\hline CEF2-C-436 & S-891b & 161 & 3.43 & $<1.00$ & $<0.100$ & 16.6 & 41.1 & $<0.100$ & $<0.100$ & 1.59 & 0.717 \\
\hline CEF2-C-440 & S-892a & 163 & 3.50 & $<1.00$ & $<0.100$ & 16.9 & 40.5 & $<0.100$ & $<0.100$ & 1.60 & 0.717 \\
\hline CEF2-C-440 & S-892b & 164 & 3.43 & $<1.00$ & $<0.100$ & 16.8 & 40.2 & $<0.100$ & $<0.100$ & 1.61 & 0.718 \\
\hline CEF2-C-445 & S-893a & 170 & 3.54 & $<1.00$ & $<0.100$ & 17.3 & 42.2 & $<0.100$ & $<0.100$ & 1.61 & 0.716 \\
\hline CEF2-C-445 & S-893b & 169 & 3.56 & $<1.00$ & $<0.100$ & 17.0 & 42.6 & $<0.100$ & $<0.100$ & 1.62 & 0.716 \\
\hline CEF2-C-486 & S-894a & 165 & 3.24 & $<1.00$ & $<0.100$ & 15.5 & 38.5 & $<0.100$ & $<0.100$ & 1.22 & 0.715 \\
\hline CEF2-C-486 & S-894b & 167 & 3.22 & $<1.00$ & $<0.100$ & 15.4 & 38.0 & $<0.100$ & $<0.100$ & 1.22 & 0.717 \\
\hline
\end{tabular}


Table A-29. Condensate Anions Set 1 (mg/L)

\begin{tabular}{|c|c|c|c|c|c|c|c|c|c|c|}
\hline Sample ID & Lab ID & $\mathbf{F}$ & $\mathbf{C l}$ & $\mathrm{NO}_{2}$ & $\mathrm{NO}_{3}$ & $\mathrm{C}_{2} \mathrm{H}_{3} \mathrm{O}_{3}$ & $\mathrm{SO}_{4}$ & $\mathrm{C}_{2} \mathrm{O}_{4}$ & $\mathrm{HCO}_{2}$ & $\mathrm{PO}_{4}$ \\
\hline CEF2-C-035 & S829 & $<100$ & 80.1 & $<10.0$ & 915 & 56.0 & $<100$ & $<100$ & $<10.0$ & $<10.0$ \\
\hline CEF2-C-036 & $\mathrm{S} 830$ & $<100$ & 89.8 & $<10.0$ & 1050 & 56.9 & $<100$ & $<100$ & $<10.0$ & $<10.0$ \\
\hline CEF2-C-040 & S831 & $<100$ & 85.9 & $<10.0$ & 1060 & 57.3 & $<100$ & $<100$ & $<10.0$ & $<10.0$ \\
\hline CEF2-C-049 & S832 & $<100$ & 97.3 & $<10.0$ & 1240 & 62.6 & $<100$ & $<100$ & $<10.0$ & $<10.0$ \\
\hline CEF2-C-058 & S833 & $<100$ & 102 & $<10.0$ & 1310 & 65.0 & $<100$ & $<100$ & 21.5 & $<10.0$ \\
\hline CEF2-C-073 & S966 & $<100$ & 130 & $<10.0$ & 1540 & 96.0 & $<100$ & $<100$ & 109 & $<10.0$ \\
\hline CEF2-C-079 (A) & S-805 & $<100$ & 151 & $<100$ & 1570 & $<100$ & $<100$ & $<100$ & $<100$ & $<100$ \\
\hline CEF2-C-079 (B) & S-805 & $<100$ & 153 & $<100$ & 1580 & $<100$ & $<100$ & $<100$ & $<100$ & $<100$ \\
\hline CEF2-C-080 (A) & S-806 & $<100$ & 149 & $<100$ & 1570 & $<100$ & $<100$ & $<100$ & $<100$ & $<100$ \\
\hline CEF2-C-080 (B) & S-806 & $<100$ & 152 & $<100$ & 1570 & $<100$ & $<100$ & $<100$ & $<100$ & $<100$ \\
\hline CEF2-C-081 (A) & S-807 & $<100$ & 156 & $<100$ & 1590 & $<100$ & $<100$ & $<100$ & $<100$ & $<100$ \\
\hline CEF2-C-081 (B) & S-807 & $<100$ & 155 & $<100$ & 1600 & $<100$ & $<100$ & $<100$ & $<100$ & $<100$ \\
\hline CEF2-C-082 (A) & S-808 & $<100$ & 156 & $<100$ & 1590 & $<100$ & $<100$ & $<100$ & $<100$ & $<100$ \\
\hline CEF2-C-082 (B) & S-808 & $<100$ & 155 & $<100$ & 1590 & $<100$ & $<100$ & $<100$ & $<100$ & $<100$ \\
\hline CEF2-C-083 (A) & S-809 & $<100$ & 151 & $<100$ & 1590 & $<100$ & $<100$ & $<100$ & $<100$ & $<100$ \\
\hline CEF2-C-083 (B) & S-809 & $<100$ & 151 & $<100$ & 1590 & $<100$ & $<100$ & $<100$ & $<100$ & $<100$ \\
\hline CEF2-C-084 (A) & S-810 & $<100$ & 153 & $<100$ & 1600 & $<100$ & $<100$ & $<100$ & $<100$ & $<100$ \\
\hline CEF2-C-084 (B) & S-810 & $<100$ & 153 & $<100$ & 1600 & $<100$ & $<100$ & $<100$ & $<100$ & $<100$ \\
\hline CEF2-C-085 (A) & S-811 & $<100$ & 151 & $<100$ & 1590 & $<100$ & $<100$ & $<100$ & $<100$ & $<100$ \\
\hline CEF2-C-085 (B) & S-811 & $<100$ & 152 & $<100$ & 1590 & $<100$ & $<100$ & $<100$ & $<100$ & $<100$ \\
\hline CEF2-C-087 (A) & S-812 & $<100$ & 152 & $<100$ & 1610 & $<100$ & $<100$ & $<100$ & $<100$ & $<100$ \\
\hline CEF2-C-087 (B) & S-812 & $<100$ & 151 & $<100$ & 1620 & $<100$ & $<100$ & $<100$ & $<100$ & $<100$ \\
\hline CEF2-C-089 & S834 & $<100$ & 133 & $<10.0$ & 1670 & 94.6 & $<100$ & $<100$ & 119 & $<10.0$ \\
\hline CEF2-C-092 & S835 & $<100$ & 135 & $<10.0$ & 1640 & 91.8 & $<100$ & $<100$ & 115 & $<10.0$ \\
\hline CEF2-C-106 & S836 & $<100$ & 126 & $<10.0$ & 1810 & 87.5 & $<100$ & $<100$ & 117 & $<10.0$ \\
\hline CEF2-C-114 & S837 & $<100$ & 103 & $<10.0$ & 1380 & 71.5 & $<100$ & $<100$ & 34.1 & $<10.0$ \\
\hline CEF2-C-122 & S838 & $<100$ & 126 & $<10.0$ & 1890 & 88.0 & $<100$ & $<100$ & 145 & $<10.0$ \\
\hline CEF2-C-265 (A) & S-813 & $<100$ & 154 & $<100$ & 1800 & 115 & $<100$ & $<100$ & $<100$ & $<100$ \\
\hline
\end{tabular}


Table A-30. Condensate Anions Set $2(\mathrm{mg} / \mathrm{L})$

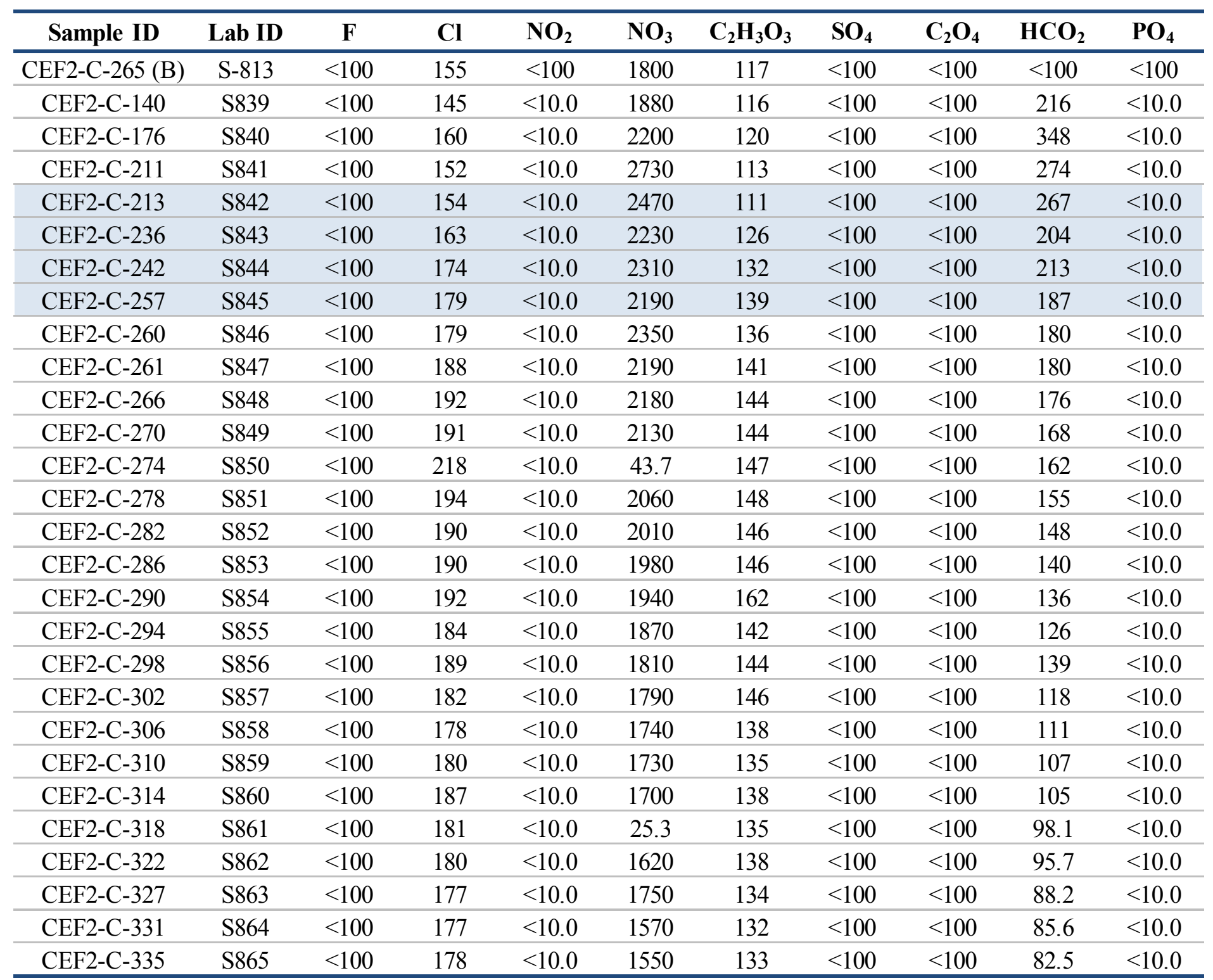


Table A-31. Condensate Anions Set 3 (mg/L)

\begin{tabular}{|c|c|c|c|c|c|c|c|c|c|c|}
\hline Sample ID & Lab ID & $\mathbf{F}$ & Cl & $\mathrm{NO}_{2}$ & $\mathrm{NO}_{3}$ & $\mathrm{C}_{2} \mathrm{H}_{3} \mathrm{O}_{3}$ & $\mathrm{SO}_{4}$ & $\mathrm{C}_{2} \mathrm{O}_{4}$ & $\mathrm{HCO}_{2}$ & $\mathrm{PO}_{4}$ \\
\hline CEF2-C-339 & S866 & $<100$ & 182 & $<10.0$ & 1540 & 141 & $<100$ & $<100$ & 83.8 & $<10.0$ \\
\hline CEF2-C-343 & S867 & $<100$ & 181 & $<10.0$ & 1540 & 135 & $<100$ & $<100$ & 79.4 & $<10.0$ \\
\hline CEF2-C-347 & S868 & $<100$ & 177 & $<10.0$ & 1490 & 132 & $<100$ & $<100$ & 75.4 & $<10.0$ \\
\hline CEF2-C-351 & S869 & $<100$ & 197 & $<10.0$ & 1460 & 137 & $<100$ & $<100$ & 72.4 & $<10.0$ \\
\hline CEF2-C-355 & S870 & $<100$ & 177 & $<10.0$ & 1450 & 132 & $<100$ & $<100$ & 67.7 & $<10.0$ \\
\hline CEF2-C-359 & S871 & $<100$ & 186 & $<10.0$ & 1390 & 131 & $<100$ & $<100$ & 80.5 & $<10.0$ \\
\hline CEF2-C-363 & S872 & $<100$ & 171 & $<10.0$ & 1400 & 131 & $<100$ & $<100$ & 62.4 & $<10.0$ \\
\hline CEF2-C-367 & S873 & $<100$ & 174 & $<10.0$ & 1400 & 132 & $<100$ & $<100$ & 61.2 & $<10.0$ \\
\hline CEF2-C-371 & S874 & $<100$ & 170 & $<10.0$ & 1400 & 129 & $<100$ & $<100$ & 61.7 & $<10.0$ \\
\hline CEF2-C-376 & S875 & $<100$ & 166 & $<10.0$ & 1380 & 128 & $<100$ & $<100$ & 60.0 & $<10.0$ \\
\hline CEF2-C-380 & S876 & $<100$ & 165 & $<10.0$ & 1410 & 126 & $<100$ & $<100$ & 58.5 & $<10.0$ \\
\hline CEF2-C-384 & S877 & $<100$ & 160 & $<10.0$ & 1400 & 123 & $<100$ & $<100$ & 57.1 & $<10.0$ \\
\hline CEF2-C-388 & S878 & $<100$ & 155 & $<10.0$ & 1400 & 120 & $<100$ & $<100$ & 55.4 & $<10.0$ \\
\hline CEF2-C-391 & S879 & $<100$ & 152 & $<10.0$ & 1390 & 118 & $<100$ & $<100$ & 53.7 & $<10.0$ \\
\hline CEF2-C-392 & S880 & $<100$ & 153 & $<10.0$ & 1400 & 121 & $<100$ & $<100$ & 53.7 & $<10.0$ \\
\hline CEF2-C-401 & S881 & $<100$ & 149 & $<10.0$ & 1390 & 114 & $<100$ & $<100$ & 48.3 & $<10.0$ \\
\hline CEF2-C-410 & S882 & $<100$ & 142 & $<10.0$ & 1420 & 113 & $<100$ & $<100$ & 55.4 & $<10.0$ \\
\hline CEF2-C-411 & S883 & $<100$ & 140 & $<10.0$ & 1400 & 109 & $<100$ & $<100$ & 53.9 & $<10.0$ \\
\hline CEF2-C-416 & S884 & $<100$ & 145 & $<10.0$ & 1400 & 115 & $<100$ & $<100$ & 55.9 & $<10.0$ \\
\hline CEF2-C-420 & S885 & $<100$ & 138 & $<10.0$ & 1390 & 111 & $<100$ & $<100$ & 56.4 & $<10.0$ \\
\hline CEF2-C-424 & S886 & $<100$ & 135 & $<10.0$ & 1370 & 109 & $<100$ & $<100$ & 57.8 & $<10.0$ \\
\hline CEF2-C-428 & S887 & $<100$ & 136 & $<10.0$ & 1380 & 112 & $<100$ & $<100$ & $<10.0$ & $<10.0$ \\
\hline CEF2-C-432 & S890 & $<100$ & 134 & $<10.0$ & 1400 & 108 & $<100$ & $<100$ & 64.3 & $<10.0$ \\
\hline CEF2-C-436 & S891 & $<100$ & 135 & $<10.0$ & 1410 & 109 & $<100$ & $<100$ & 66.7 & $<10.0$ \\
\hline CEF2-C-440 & S892 & $<100$ & 139 & $<10.0$ & 1410 & 111 & $<100$ & $<100$ & 69.8 & $<10.0$ \\
\hline CEF2-C-445 & S893 & $<100$ & 146 & $<10.0$ & 1450 & 115 & $<100$ & $<100$ & 79.5 & $<10.0$ \\
\hline CEF2-C-486 & S894 & $<100$ & 139 & $<10.0$ & 1620 & 98.2 & $<100$ & $<100$ & 96.9 & $<10.0$ \\
\hline
\end{tabular}


Table A-32. Condensate pH, Density and Total Solids Set 1

\begin{tabular}{|c|c|c|c|c|}
\hline Sample ID & Lab ID & $\mathbf{p H}$ & $\begin{array}{c}\text { Density } \\
\left(\mathrm{g} / \mathrm{cm}^{3}\right)\end{array}$ & $\begin{array}{r}\text { Total } \\
\text { Solids }\end{array}$ \\
\hline CEF2-C-035 & S829 & 2.29 & 0.999 & $<0.10 \%$ \\
\hline CEF2-C-036 & S830 & 2.34 & 0.999 & $<0.10 \%$ \\
\hline CEF2-C-040 & S831 & 2.29 & 0.999 & $<0.10 \%$ \\
\hline CEF2-C-049 & S832 & 2.26 & 0.999 & $<0.10 \%$ \\
\hline CEF2-C-058 & S833 & 2.33 & 0.999 & $<0.10 \%$ \\
\hline CEF2-C-073 & S966 & 3.45 & 0.999 & $<0.10 \%$ \\
\hline CEF2-C-079 (A) & S-805 & \multirow{2}{*}{4.64} & 1.00 & $0.21 \%$ \\
\hline CEF2-C-079 (B) & S-805 & & 1.00 & $0.13 \%$ \\
\hline CEF2-C-080 (A) & S-806 & \multirow{2}{*}{3.63} & 1.00 & $0.19 \%$ \\
\hline CEF2-C-080 (B) & S-806 & & 1.00 & $0.13 \%$ \\
\hline CEF2-C-081 (A) & S-807 & \multirow{2}{*}{3.53} & 1.00 & $0.26 \%$ \\
\hline CEF2-C-081 (B) & S-807 & & 1.00 & $0.17 \%$ \\
\hline CEF2-C-082 (A) & S-808 & \multirow{2}{*}{3.48} & 1.00 & $<0.10 \%$ \\
\hline CEF2-C-082 (B) & S-808 & & 1.00 & $<0.10 \%$ \\
\hline CEF2-C-083 (A) & S-809 & \multirow{2}{*}{3.40} & 1.00 & $0.18 \%$ \\
\hline CEF2-C-083 (B) & S-809 & & 1.00 & $0.17 \%$ \\
\hline CEF2-C-084 (A) & S-810 & \multirow{2}{*}{3.39} & 1.00 & $0.17 \%$ \\
\hline CEF2-C-084 (B) & S-810 & & 1.00 & $<0.10 \%$ \\
\hline CEF2-C-085 (A) & S-811 & \multirow{2}{*}{3.08} & 1.00 & $0.12 \%$ \\
\hline CEF2-C-085 (B) & S-811 & & 1.00 & $0.17 \%$ \\
\hline CEF2-C-087 (A) & S-812 & \multirow{2}{*}{2.96} & 1.00 & $0.13 \%$ \\
\hline CEF2-C-087 (B) & S-812 & & 1.00 & $<0.10 \%$ \\
\hline CEF2-C-089 & S834 & 2.99 & 0.999 & $0.21 \%$ \\
\hline CEF2-C-092 & S835 & 2.99 & 0.999 & $0.23 \%$ \\
\hline CEF2-C-106 & S836 & 2.59 & 1.00 & $0.22 \%$ \\
\hline CEF2-C-114 & S837 & 2.29 & 0.999 & $<0.10 \%$ \\
\hline CEF2-C-122 & S838 & 2.77 & 1.00 & $<0.10 \%$ \\
\hline CEF2-C-265 (A) & S-813 & \multirow{2}{*}{3.03} & 1.00 & $<0.10 \%$ \\
\hline CEF2-C-265 (B) & S-813 & & 1.00 & $0.13 \%$ \\
\hline CEF2-C-140 & S839 & 3.48 & 1.00 & $0.21 \%$ \\
\hline CEF2-C-176 & S840 & 2.69 & 1.00 & $0.35 \%$ \\
\hline CEF2-C-211 & S841 & 2.31 & 1.00 & $0.31 \%$ \\
\hline CEF2-C-213 & S842 & 2.31 & 1.00 & $0.37 \%$ \\
\hline CEF2-C-236 & S843 & 2.38 & 1.00 & $0.21 \%$ \\
\hline CEF2-C-242 & S844 & 2.67 & 1.00 & $0.35 \%$ \\
\hline CEF2-C-257 & S845 & 2.41 & 1.00 & $0.37 \%$ \\
\hline CEF2-C-260 & S846 & 2.40 & 1.00 & $0.36 \%$ \\
\hline CEF2-C-261 & S847 & 2.47 & 1.00 & $0.33 \%$ \\
\hline CEF2-C-266 & S848 & 2.48 & 1.00 & $0.32 \%$ \\
\hline CEF2-C-270 & S849 & 2.49 & 1.00 & $0.37 \%$ \\
\hline CEF2-C-274 & $\mathrm{S} 850$ & 2.50 & 1.00 & $0.47 \%$ \\
\hline
\end{tabular}


Table A-33. Condensate pH, Density and Total Solids Set 2

\begin{tabular}{|c|c|c|c|c|}
\hline Sample ID & Lab ID & pH & $\begin{array}{l}\text { Density } \\
\left(\mathrm{g} / \mathrm{cm}^{3}\right)\end{array}$ & $\begin{array}{r}\text { Total } \\
\text { Solids }\end{array}$ \\
\hline CEF2-C-278 & S851 & 2.53 & 1.00 & $0.27 \%$ \\
\hline CEF2-C-282 & S852 & 2.54 & 1.00 & $0.30 \%$ \\
\hline CEF2-C-286 & S853 & 2.59 & 1.00 & $<0.10 \%$ \\
\hline CEF2-C-290 & S854 & 2.59 & 1.00 & $<0.10 \%$ \\
\hline CEF2-C-294 & S855 & 2.60 & 0.999 & $0.31 \%$ \\
\hline CEF2-C-298 & S856 & 2.65 & 0.999 & $0.37 \%$ \\
\hline CEF2-C-302 & S857 & 2.66 & 0.999 & $0.32 \%$ \\
\hline CEF2-C-306 & S858 & 2.50 & 0.999 & $0.36 \%$ \\
\hline CEF2-C-310 & S859 & 2.55 & 0.999 & $0.34 \%$ \\
\hline CEF2-C-314 & S860 & 2.71 & 0.999 & $0.32 \%$ \\
\hline CEF2-C-318 & S861 & 2.60 & 0.999 & $0.21 \%$ \\
\hline CEF2-C-322 & S862 & 2.74 & 0.999 & $0.32 \%$ \\
\hline CEF2-C-327 & S863 & 2.78 & 0.999 & $0.26 \%$ \\
\hline CEF2-C-331 & S864 & 2.83 & 0.999 & $0.37 \%$ \\
\hline CEF2-C-335 & S865 & 2.87 & 0.999 & $0.10 \%$ \\
\hline CEF2-C-339 & S866 & 2.83 & 0.999 & $0.26 \%$ \\
\hline CEF2-C-343 & S867 & 2.84 & 0.999 & $0.15 \%$ \\
\hline CEF2-C-347 & S868 & 2.93 & 0.999 & $0.31 \%$ \\
\hline CEF2-C-351 & S869 & 2.96 & 0.999 & $0.36 \%$ \\
\hline CEF2-C-355 & S870 & 2.97 & 0.999 & $0.32 \%$ \\
\hline CEF2-C-359 & S871 & 3.00 & 0.999 & $0.15 \%$ \\
\hline CEF2-C-363 & S872 & 3.01 & 0.999 & $0.32 \%$ \\
\hline CEF2-C-367 & S873 & 2.97 & 0.999 & $<0.10 \%$ \\
\hline CEF2-C-371 & S874 & 2.97 & 0.999 & $<0.10 \%$ \\
\hline CEF2-C-376 & S875 & 2.90 & 0.999 & $0.25 \%$ \\
\hline CEF2-C-380 & S876 & 2.84 & 0.999 & $0.21 \%$ \\
\hline CEF2-C-384 & S877 & 2.79 & 0.999 & $0.31 \%$ \\
\hline CEF2-C-388 & S878 & 2.74 & 0.999 & $0.26 \%$ \\
\hline CEF2-C-391 & S879 & 2.71 & 0.999 & $0.16 \%$ \\
\hline CEF2-C-392 & S880 & 2.68 & 0.999 & $0.24 \%$ \\
\hline CEF2-C-401 & S881 & 3.92 & 0.999 & $<0.10 \%$ \\
\hline CEF2-C-410 & S882 & 3.08 & 0.999 & $0.10 \%$ \\
\hline CEF2-C-411 & S883 & 3.28 & 0.999 & $<0.10 \%$ \\
\hline CEF2-C-416 & S884 & 3.59 & 0.999 & $<0.10 \%$ \\
\hline CEF2-C-420 & S885 & 3.99 & 0.999 & $0.10 \%$ \\
\hline CEF2-C-424 & S886 & 4.09 & 0.999 & $0.10 \%$ \\
\hline CEF2-C-428 & S887 & 4.10 & 0.999 & $<0.10 \%$ \\
\hline CEF2-C-432 & S890 & 4.13 & 0.999 & $<0.10 \%$ \\
\hline CEF2-C-436 & S891 & 4.19 & 0.999 & $0.15 \%$ \\
\hline CEF2-C-440 & S892 & 4.21 & 0.999 & $0.20 \%$ \\
\hline CEF2-C-445 & S893 & 4.27 & 0.999 & $0.20 \%$ \\
\hline CEF2-C-486 & S894 & 4.03 & 0.999 & $0.21 \%$ \\
\hline
\end{tabular}


Table A-34. Condensate TOC

\begin{tabular}{lc}
\hline Sample ID & $\begin{array}{c}\text { TOC } \\
\text { (ppm) }\end{array}$ \\
\hline CEF2-C-035 & 13.19 \\
\hline CEF2-C-036 & 11.99 \\
\hline CEF2-C-040 & 14.46 \\
\hline CEF2-C-049 & 19.89 \\
\hline CEF2-C-058 & 38.06 \\
\hline CEF2-C-073 & 159.88 \\
\hline CEF2-C-079 & 167.89 \\
\hline CEF2-C-083 & 164.33 \\
\hline CEF2-C-087 & 158.96 \\
\hline CEF2-C-089 & 156.93 \\
\hline CEF2-C-092 & 161.66 \\
\hline CEF2-C-106 & 150.58 \\
\hline CEF2-C-114 & 43.68 \\
\hline CEF2-C-122 & 172.84 \\
\hline CEF2-C-265 & 209.11 \\
\hline CEF2-C-140 & 245.8 \\
\hline CEF2-C-176 & 284.16 \\
\hline CEF2-C-211 & 255 \\
\hline CEF2-C-213 & 250.61 \\
\hline CEF2-C-236 & 193.19 \\
\hline CEF2-C-242 & 198.93 \\
\hline CEF2-C-257 & 174.55 \\
\hline CEF2-C-260 & 168.18 \\
\hline CEF2-C-261 & 171.67 \\
\hline
\end{tabular}

\begin{tabular}{lc}
\hline Sample ID & $\begin{array}{c}\text { TOC } \\
\text { (ppm) }\end{array}$ \\
\hline CEF2-C-266 & 164.28 \\
\hline CEF2-C-270 & 160.57 \\
\hline CEF2-C-274 & 152.37 \\
\hline CEF2-C-278 & 147.19 \\
\hline CEF2-C-282 & 140.45 \\
\hline CEF2-C-286 & 135.44 \\
\hline CEF2-C-290 & 127.11 \\
\hline CEF2-C-294 & 123.33 \\
\hline CEF2-C-298 & 115.85 \\
\hline CEF2-C-302 & 111.57 \\
\hline CEF2-C-306 & 108.31 \\
\hline CEF2-C-310 & 106.12 \\
\hline CEF2-C-314 & 100.81 \\
\hline CEF2-C-318 & 98.12 \\
\hline CEF2-C-322 & 95.79 \\
\hline CEF2-C-327 & 91.46 \\
\hline CEF2-C-331 & 89.18 \\
\hline CEF2-C-335 & 87.63 \\
\hline CEF2-C-335 & 87.04 \\
\hline CEF2-C-335 & 76.24 \\
\hline CEF2-C-339 & 85.29 \\
\hline CEF2-C-343 & 83.76 \\
\hline CEF2-C-347 & 82.89 \\
\hline CEF2-C-351 & 80.8 \\
\hline
\end{tabular}

\begin{tabular}{lc}
\hline Sample ID & $\begin{array}{c}\text { TOC } \\
\text { (ppm) }\end{array}$ \\
\hline CEF2-C-351 & 79.93 \\
\hline CEF2-C-359 & 74.32 \\
\hline CEF2-C-363 & 72.35 \\
\hline CEF2-C-367 & 69.78 \\
\hline CEF2-C-371 & 66.9 \\
\hline CEF2-C-376 & 64.5 \\
\hline CEF2-C-380 & 63.69 \\
\hline CEF2-C-384 & 60.89 \\
\hline CEF2-C-388 & 59.27 \\
\hline CEF2-C-391 & 57.79 \\
\hline CEF2-C-392 & 57.42 \\
\hline CEF2-C-401 & 61 \\
\hline CEF2-C-410 & 71.45 \\
\hline CEF2-C-411 & 74.55 \\
\hline CEF2-C-416 & 79.41 \\
\hline CEF2-C-420 & 84.56 \\
\hline CEF2-C-424 & 90.76 \\
\hline CEF2-C-426 & 94.35 \\
\hline CEF2-C-432 & 96.89 \\
\hline CEF2-C-436 & 98.89 \\
\hline CEF2-C-440 & 102.47 \\
\hline CEF2-C-445 & 112.04 \\
\hline CEF2-C-486 & 131.23 \\
\hline
\end{tabular}


Table A-35. Condensate Tank Solids Cations (mg/Kg)

\begin{tabular}{|c|c|c|c|c|c|c|c|c|c|c|c|}
\hline Sample ID & Lab ID & Al & $\mathbf{B a}$ & $\mathbf{C a}$ & $\mathrm{Cr}$ & $\mathbf{C u}$ & Fe & $\mathbf{K}$ & $\mathbf{L i}$ & Mg & Mn \\
\hline Condensate Tank Solids (A) & S989 & 19600 & 185 & 698 & 124 & 413 & 101000 & 90.0 & 560 & 3190 & 21300 \\
\hline Condensate Tank Solids (B) & S989 & 19800 & 186 & 699 & 124 & 415 & 101000 & 91.0 & 560 & 3180 & 21300 \\
\hline Sample ID & Lab ID & $\mathbf{N a}$ & $\mathbf{N i}$ & $\mathbf{P}$ & $\mathbf{P b}$ & $\mathbf{S}$ & $\mathbf{S i}$ & Sn & $\mathbf{T i}$ & Zn & $\mathbf{Z r}$ \\
\hline Condensate Tank Solids (A) & S989 & 2240 & 12100 & 498 & 102 & 2040 & 856 & 55.0 & 160 & 512 & 15.0 \\
\hline Condensate Tank Solids (B) & S989 & 2260 & 12000 & 495 & 102 & 2050 & 844 & 55.0 & 160 & 515 & 15.2 \\
\hline
\end{tabular}

Table A-36. Condensate Tank Solids Anions (mg/Kg)

\begin{tabular}{ccccccccccc}
\hline Sample ID & Lab ID & $\mathbf{F}$ & $\mathbf{C l}$ & $\mathbf{N O}_{\mathbf{2}}$ & $\mathbf{N O}_{\mathbf{3}}$ & $\mathbf{C}_{\mathbf{2}} \mathbf{H}_{\mathbf{3}} \mathbf{O}_{\mathbf{3}}$ & $\mathbf{S O}_{\mathbf{4}}$ & $\mathbf{C}_{\mathbf{2}} \mathbf{O}_{\mathbf{4}}$ & $\mathbf{H C O}_{\mathbf{2}}$ & $\mathbf{P O}_{\mathbf{4}}$ \\
\hline Condensate Tank Solids (A) & $\mathrm{S} 989$ & $<100$ & 618 & 112 & 5270 & $<100$ & 495 & $<100$ & 520 & $<100$ \\
\hline Condensate Tank Solids (B) & $\mathrm{S} 989$ & $<100$ & 625 & 113 & 5220 & $<100$ & 495 & $<100$ & 534 & $<100$ \\
\hline
\end{tabular}


Table A-37. Off-gas Filter Solids Summary

\begin{tabular}{|c|c|c|c|c|c|c|c|}
\hline Sample ID & Lab ID & Date/Time In & $\begin{array}{c}\text { Date/Time } \\
\text { Out }\end{array}$ & $\begin{array}{c}\text { Initial We ight } \\
(\mathrm{g})\end{array}$ & $\begin{array}{c}\text { Final Weight } \\
\text { (g) }\end{array}$ & $\begin{array}{c}\text { Solids Weight } \\
(\mathrm{g})\end{array}$ & Test Conditions \\
\hline CEF2-FL-B ${ }^{\$}$ & S967 & $2 / 24 / 1411: 36$ & 2/26/14 4:09 & 59.5 & 116.5 & 57.0 & $125 \%$ feed, bubbled \\
\hline CEF2-FL-C & S968 & 2/26/14 4:09 & 2/27/14 5:14 & 59.5 & 112.0 & 52.5 & $125 \%$ feed, bubbled \\
\hline CEF2-FL-M & S969 & 2/27/14 5:14 & $2 / 27 / 0418: 15$ & 61.6 & 72.5 & 10.9 & $125 \%$ feed, bubbled \\
\hline CEF2-FL-A ${ }^{*}$ & S970 & $2 / 27 / 1418: 15$ & $2 / 28 / 141: 05$ & 59.2 & 65.5 & 6.3 & $125 \%$ feed, bubbled \\
\hline CEF2-FL-Q & S971 & $2 / 28 / 141: 05$ & $2 / 28 / 1416: 47$ & 60.3 & 90.0 & 29.7 & $125 \%$ feed, bubbled \\
\hline CEF2-FL-A $^{*}$ & S970 & $2 / 28 / 1416: 47$ & $2 / 28 / 1420: 05$ & 59.2 & 65.5 & 6.3 & $125 \%$ feed, bubbled \\
\hline CEF2-FL-G & S972 & $2 / 28 / 1420: 05$ & $3 / 1 / 144: 11$ & 58.8 & 62.5 & 3.7 & $125 \%$ feed, non-bubbled \\
\hline CEF2-FL-D & S973 & $3 / 1 / 144: 11$ & $3 / 2 / 144: 40$ & 62.5 & 91.5 & 29.0 & $125 \%$ feed, non-bubbled \\
\hline CEF2-FL-E & S974 & $3 / 2 / 144: 40$ & $3 / 2 / 147: 47$ & 61.9 & 64.5 & 2.6 & $125 \%$ feed, non-bubbled \\
\hline CEF2-FL-F & S975 & $3 / 2 / 147: 47$ & $3 / 4 / 146: 20$ & 61.6 & 92.0 & 30.4 & $100 \%$ feed, non-bubbled \\
\hline CEF2-FL-H & S976 & $3 / 4 / 146: 20$ & 3/4/14 18:45 & 61.0 & 107.0 & 46.0 & $100 \%$ feed, non-bubbled \\
\hline CEF2-FL-K & S977 & $3 / 4 / 1418: 45$ & $3 / 6 / 142: 00$ & 59.0 & 119.0 & 60.0 & $100 \%$ feed, bubbled \\
\hline CEF2-FL-L & S978 & $3 / 6 / 142: 00$ & $3 / 8 / 149: 30$ & 61.8 & 132.5 & 70.7 & $100 \%$ feed, bubbled \\
\hline CEF2-FL-N & S979 & $3 / 8 / 149: 30$ & 3/9/14 14:03 & 58.5 & 103.0 & 44.5 & $100 \%$ feed, bubbled \\
\hline CEF2-FL-P & S980 & 3/9/14 14:03 & $3 / 11 / 1420: 10$ & 61.0 & 117.0 & 56.0 & $100 \%$ feed, bubbled \\
\hline CEF2-FL-O & S981 & $3 / 11 / 1420: 10$ & 3/13/14 20:01 & 62.3 & 130.0 & 67.7 & $100 \%$ feed, bubbled \\
\hline CEF2-FL-U & S982 & 3/13/14 20:01 & $3 / 15 / 141: 29$ & 59.5 & 120.5 & 61.0 & $100 \%$ feed, bubbled \\
\hline CEF2-FL-J & S983 & $3 / 15 / 141: 29$ & $3 / 16 / 1416: 00$ & 58.0 & 105.5 & 47.5 & $100 \%$ feed, bubbled/non-bubbled \\
\hline CEF2-FL-S & S984 & $3 / 16 / 1416: 00$ & 3/19/14 10:31 & 61.6 & 150.0 & 88.4 & various feeds, non-bubbled \\
\hline CEF2-FL-T & S985 & 3/19/14 10:41 & $3 / 21 / 1412: 41$ & 61.4 & 126.0 & 64.6 & various feeds, non-bubbled \\
\hline CEF2-FL-R & S986 & --- & --- & 58.0 & 58.5 & 0.5 & various feeds, non-bubbled \\
\hline
\end{tabular}


Table A-38. Off-gas Filter Solids Cations Set 1A

\begin{tabular}{|c|c|c|c|c|c|c|c|c|c|c|c|}
\hline Sample ID & Lab ID & Al & B & $\mathbf{B a}$ & $\mathbf{C a}$ & $\mathrm{Cr}$ & $\mathbf{C u}$ & $\mathbf{F e}$ & $\mathbf{K}$ & $\mathbf{L i}$ & Mg \\
\hline CEF2-FL-B & S-967a & 6.45 & 0.477 & 0.058 & 0.267 & 0.366 & 0.101 & 23.7 & 0.030 & 0.593 & 0.888 \\
\hline CEF2-FL-B & S-967b & 6.45 & 0.453 & 0.058 & 0.129 & 0.363 & 0.099 & 23.8 & 0.028 & 0.572 & 0.892 \\
\hline CEF2-FL-C & S-968a & 5.83 & 0.362 & 0.056 & 0.333 & 0.244 & 0.114 & 25.6 & 0.020 & 0.411 & 0.937 \\
\hline CEF2-FL-C & S-968b & 5.97 & 0.360 & 0.058 & 0.168 & 0.254 & 0.108 & 26.4 & 0.022 & 0.411 & 0.966 \\
\hline CEF2-FL-M & S-969a & 4.31 & 1.43 & 0.041 & 0.067 & 0.097 & 0.039 & 11.2 & 0.053 & 1.82 & 0.204 \\
\hline CEF2-FL-M & S-969b & 4.29 & 1.47 & 0.041 & 0.084 & 0.097 & 0.043 & 11.2 & 0.057 & 1.87 & 0.199 \\
\hline CEF2-FL-A & S-970a & 4.32 & 1.47 & 0.036 & 0.098 & 0.100 & 0.033 & 10.8 & 0.051 & 1.87 & 0.147 \\
\hline CEF2-FL-A & S-970b & 4.36 & 1.48 & 0.036 & 0.102 & 0.100 & 0.033 & 10.9 & 0.051 & 1.89 & 0.150 \\
\hline CEF2-FL-Q & S-971a & 7.42 & 0.901 & 0.064 & 0.267 & 0.164 & 0.088 & 18.5 & 0.066 & 1.23 & 0.397 \\
\hline CEF2-FL-Q & S-971b & 7.37 & 0.878 & 0.066 & 0.230 & 0.161 & 0.088 & 18.4 & 0.068 & 1.19 & 0.392 \\
\hline CEF2-FL-G & S-972a & 4.09 & 1.57 & 0.038 & 0.157 & 0.087 & 0.045 & 9.86 & 0.070 & 2.11 & 0.115 \\
\hline CEF2-FL-G & S-972b & 4.21 & 1.62 & 0.038 & 0.176 & 0.101 & 0.038 & 10.1 & 0.072 & 2.16 & 0.121 \\
\hline CEF2-FL-D & S-973a & 5.71 & 1.16 & 0.052 & 0.202 & 0.144 & 0.089 & 16.4 & 0.052 & 1.52 & 0.363 \\
\hline CEF2-FL-D & S-973b & 5.53 & 1.08 & 0.052 & 0.179 & 0.147 & 0.073 & 15.9 & 0.050 & 1.44 & 0.347 \\
\hline CEF2-FL-E & S-974a & 3.39 & 1.71 & 0.035 & 0.139 & 0.074 & 0.116 & 7.39 & 0.043 & 2.25 & 0.076 \\
\hline CEF2-FL-E & S-974b & 3.33 & 1.68 & 0.035 & 0.129 & 0.074 & 0.117 & 7.28 & 0.044 & 2.21 & 0.070 \\
\hline CEF2-FL-F & S-975a & 2.86 & 1.51 & 0.032 & 0.133 & 0.075 & 0.045 & 7.57 & 0.061 & 2.01 & 0.085 \\
\hline CEF2-FL-F & S-975b & 2.98 & 1.59 & 0.032 & 0.156 & 0.078 & 0.032 & 7.81 & 0.060 & 2.10 & 0.094 \\
\hline CEF2-FL-H & S-976a & 5.27 & 1.40 & 0.049 & 0.420 & 0.081 & 0.183 & 9.88 & 0.101 & 1.95 & 0.198 \\
\hline CEF2-FL-H & S-976b & 5.26 & 1.35 & 0.050 & 0.405 & 0.076 & 0.203 & 9.85 & 0.100 & 1.91 & 0.194 \\
\hline CEF2-FL-K & S-977a & 6.26 & 0.593 & 0.066 & 0.178 & 0.175 & 0.078 & 17.5 & 0.038 & 0.750 & 0.346 \\
\hline CEF2-FL-K & S-977b & 6.37 & 0.609 & 0.066 & 0.268 & 0.172 & 0.089 & 17.6 & 0.039 & 0.770 & 0.350 \\
\hline CEF2-FL-L & S-978a & 4.98 & 0.389 & 0.071 & 0.250 & 0.221 & 0.089 & 20.8 & 0.027 & 0.422 & 0.541 \\
\hline CEF2-FL-L & S-978b & 4.82 & 0.383 & 0.072 & 0.262 & 0.215 & 0.082 & 20.3 & 0.027 & 0.414 & 0.520 \\
\hline CEF2-FL-N & S-979a & 4.06 & 0.841 & 0.054 & 0.198 & 0.176 & 0.136 & 17.4 & 0.028 & 1.12 & 0.477 \\
\hline CEF2-FL-N & S-979b & 4.19 & 0.791 & 0.053 & 0.178 & 0.174 & 0.118 & 18.0 & 0.029 & 1.07 & 0.498 \\
\hline CEF2-FL-P & S-980a & 4.65 & 0.325 & 0.065 & 0.169 & 0.221 & 0.089 & 25.7 & 0.022 & 0.386 & 0.801 \\
\hline CEF2-FL-P & S-980b & 4.75 & 0.333 & 0.065 & 0.160 & 0.221 & 0.092 & 25.9 & 0.022 & 0.399 & 0.809 \\
\hline
\end{tabular}


Table A-39. Off-gas Filter Solids Cations Set 1B

\begin{tabular}{|c|c|c|c|c|c|c|c|c|c|c|}
\hline Lab ID & Mn & $\mathbf{N a}$ & $\mathbf{N i}$ & $\mathbf{P}$ & $\mathbf{S}$ & Si & Sn & $\mathbf{T i}$ & $\mathbf{Z n}$ & $\mathbf{Z r}$ \\
\hline S-967a & 6.38 & 1.67 & 3.39 & $<0.100$ & 0.464 & 9.93 & $<0.100$ & 0.061 & 0.123 & 0.144 \\
\hline S-967b & 6.40 & 1.67 & 3.40 & $<0.100$ & 0.454 & 9.86 & $<0.100$ & 0.060 & 0.122 & 0.121 \\
\hline S-968a & 6.26 & 1.16 & 3.58 & $<0.100$ & 0.548 & 9.75 & $<0.100$ & 0.065 & 0.129 & 0.087 \\
\hline S-968b & 6.44 & 1.15 & 3.71 & $<0.100$ & 0.564 & 9.72 & $<0.100$ & 0.066 & 0.134 & 0.094 \\
\hline S-969a & 2.27 & 4.53 & 1.35 & $<0.100$ & 0.313 & 21.4 & $<0.100$ & 0.032 & 0.050 & 0.119 \\
\hline S-969b & 2.25 & 4.54 & 1.35 & $<0.100$ & 0.313 & 21.7 & $<0.100$ & 0.031 & 0.051 & 0.120 \\
\hline S-970a & 2.16 & 4.58 & 1.26 & $<0.100$ & 0.303 & 22.1 & $<0.100$ & 0.029 & 0.045 & 0.113 \\
\hline S-970b & 2.17 & 4.56 & 1.26 & $<0.100$ & 0.305 & 22.1 & $<0.100$ & 0.029 & 0.045 & 0.113 \\
\hline S-971a & 4.00 & 3.94 & 2.00 & $<0.100$ & 0.394 & 13.6 & $<0.100$ & 0.047 & 0.072 & 0.121 \\
\hline S-971b & 4.02 & 3.95 & 2.00 & $<0.100$ & 0.405 & 13.8 & $<0.100$ & 0.047 & 0.072 & 0.121 \\
\hline S-972a & 2.04 & 5.80 & 1.03 & $<0.100$ & 0.228 & 23.0 & $<0.100$ & 0.025 & 0.039 & 0.109 \\
\hline S-972b & 2.08 & 5.78 & 1.06 & $<0.100$ & 0.227 & 22.8 & $<0.100$ & 0.025 & 0.039 & 0.109 \\
\hline S-973a & 3.73 & 3.84 & 1.85 & $<0.100$ & 0.347 & 17.3 & $<0.100$ & 0.037 & 0.065 & 0.126 \\
\hline S-973b & 3.61 & 3.82 & 1.78 & $<0.100$ & 0.366 & 17.4 & $<0.100$ & 0.037 & 0.064 & 0.121 \\
\hline S-974a & 1.75 & 5.58 & 0.870 & $<0.100$ & 0.120 & 24.3 & $<0.100$ & 0.020 & 0.036 & 0.115 \\
\hline S-974b & 1.72 & 5.55 & 0.852 & $<0.100$ & 0.123 & 24.2 & $<0.100$ & 0.020 & 0.036 & 0.115 \\
\hline S-975a & 1.62 & 5.29 & 0.882 & $<0.100$ & 0.175 & 23.3 & $<0.100$ & 0.024 & 0.034 & 0.087 \\
\hline S-975b & 1.68 & 5.26 & 0.920 & $<0.100$ & 0.168 & 23.5 & $<0.100$ & 0.024 & 0.034 & 0.087 \\
\hline S-976a & 2.67 & 6.77 & 1.10 & $<0.100$ & 0.155 & 19.8 & $<0.100$ & 0.026 & 0.066 & 0.121 \\
\hline S-976b & 2.64 & 6.68 & 1.08 & $<0.100$ & 0.162 & 19.8 & $<0.100$ & 0.026 & 0.066 & 0.120 \\
\hline S-977a & 4.02 & 2.56 & 2.02 & $<0.100$ & 0.257 & 9.48 & $<0.100$ & 0.040 & 0.074 & 0.107 \\
\hline S-977b & 4.06 & 2.61 & 2.03 & $<0.100$ & 0.254 & 9.50 & $<0.100$ & 0.040 & 0.074 & 0.109 \\
\hline S-978a & 4.81 & 1.36 & 2.70 & $<0.100$ & 0.395 & 8.78 & $<0.100$ & 0.055 & 0.098 & 0.093 \\
\hline S-978b & 4.68 & 1.35 & 2.61 & $<0.100$ & 0.392 & 8.85 & $<0.100$ & 0.055 & 0.099 & 0.102 \\
\hline S-979a & 3.88 & 2.43 & 2.31 & $<0.100$ & 0.348 & 15.6 & $<0.100$ & 0.050 & 0.100 & 0.094 \\
\hline S-979b & 4.00 & 2.49 & 2.39 & $<0.100$ & 0.350 & 16.0 & $<0.100$ & 0.049 & 0.099 & 0.094 \\
\hline S-980a & 5.82 & 1.17 & 3.37 & $<0.100$ & 0.507 & 9.83 & $<0.100$ & 0.072 & 0.127 & 0.085 \\
\hline S-980b & 5.88 & 1.20 & 3.41 & $<0.100$ & 0.495 & 9.83 & $<0.100$ & 0.074 & 0.127 & 0.088 \\
\hline
\end{tabular}


Table A-40. Off-gas Filter Solids Cations Set 2A

\begin{tabular}{|c|c|c|c|c|c|c|c|c|c|c|c|}
\hline Sample ID & Lab ID & Al & B & $\mathbf{B a}$ & $\mathbf{C a}$ & $\mathrm{Cr}$ & $\mathrm{Cu}$ & $\mathbf{F e}$ & $\mathbf{K}$ & $\mathbf{L i}$ & Mg \\
\hline CEF2-FL-O & S-981a & 3.75 & 0.250 & 0.055 & 0.115 & 0.213 & 0.089 & 26.4 & 0.022 & 0.307 & 0.740 \\
\hline CEF2-FL-O & S-981b & 3.74 & 0.252 & 0.055 & 0.146 & 0.209 & 0.089 & 26.4 & 0.021 & 0.304 & 0.741 \\
\hline CEF2-FL-U & S-982a & 4.94 & 0.239 & 0.064 & 0.167 & 0.212 & 0.095 & 26.7 & 0.027 & 0.292 & 0.753 \\
\hline CEF2-FL-U & S-982b & 4.96 & 0.271 & 0.065 & 0.150 & 0.209 & 0.092 & 27.2 & 0.026 & 0.331 & 0.765 \\
\hline CEF2-FL-J & S-983a & 4.00 & 0.513 & 0.061 & 0.117 & 0.238 & 0.095 & 21.9 & 0.041 & 0.652 & 0.615 \\
\hline CEF2-FL-J & S-983b & 4.04 & 0.473 & 0.059 & 0.092 & 0.225 & 0.091 & 21.8 & 0.038 & 0.598 & 0.605 \\
\hline CEF2-FL-S & S-984a & 4.35 & 0.350 & 0.056 & 0.245 & 0.197 & 0.101 & 18.7 & 0.081 & 0.246 & 0.463 \\
\hline CEF2-FL-S & S-984b & 4.39 & 0.344 & 0.054 & 0.213 & 0.199 & 0.102 & 18.9 & 0.079 & 0.236 & 0.469 \\
\hline CEF2-FL-T & S-985a & 5.06 & 0.648 & 0.055 & 0.180 & 0.268 & 0.087 & 18.2 & 0.056 & 0.723 & 0.454 \\
\hline CEF2-FL-T & S-985b & 4.92 & 0.570 & 0.056 & 0.151 & 0.283 & 0.089 & 17.9 & 0.059 & 0.624 & 0.444 \\
\hline CEF2-FL-R & \multicolumn{11}{|c|}{ not enough sample for analysis } \\
\hline
\end{tabular}

Table A-41. Off-gas Filter Solids Cations Set 2B

\begin{tabular}{lccccccccccc}
\hline Sample ID & Lab ID & $\mathbf{M n}$ & $\mathbf{N a}$ & $\mathbf{N i}$ & $\mathbf{P}$ & $\mathbf{S}$ & $\mathbf{S i}$ & $\mathbf{S n}$ & $\mathbf{T i}$ & $\mathbf{Z n}$ & $\mathbf{Z r}$ \\
\hline CEF2-FL-O & S-981a & 6.15 & 0.982 & 3.17 & $<0.100$ & 0.468 & 10.8 & $<0.100$ & 0.069 & 0.116 & 0.070 \\
\hline CEF2-FL-O & S-981b & 6.15 & 0.986 & 3.17 & $<0.100$ & 0.453 & 10.8 & $<0.100$ & 0.069 & 0.115 & 0.068 \\
\hline CEF2-FL-U & S-982a & 6.64 & 1.16 & 3.15 & $<0.100$ & 0.469 & 8.67 & $<0.100$ & 0.066 & 0.116 & 0.087 \\
\hline CEF2-FL-U & S-982b & 6.77 & 1.17 & 3.24 & $<0.100$ & 0.486 & 8.70 & $<0.100$ & 0.065 & 0.118 & 0.066 \\
\hline CEF2-FL-J & S-983a & 5.22 & 1.69 & 2.70 & $<0.100$ & 0.463 & 12.4 & $<0.100$ & 0.059 & 0.108 & 0.097 \\
\hline CEF2-FL-J & S-983b & 5.18 & 1.75 & 2.69 & $<0.100$ & 0.445 & 12.9 & $<0.100$ & 0.057 & 0.103 & 0.096 \\
\hline CEF2-FL-S & S-984a & 4.80 & 1.84 & 2.29 & $<0.100$ & 0.336 & 13.2 & $<0.100$ & 0.050 & 0.095 & 0.063 \\
\hline CEF2-FL-S & S-984b & 4.85 & 1.87 & 2.32 & $<0.100$ & 0.332 & 13.2 & $<0.100$ & 0.048 & 0.093 & 0.063 \\
\hline CEF2-FL-T & S-985a & 4.55 & 2.26 & 2.27 & $<0.100$ & 0.346 & 13.3 & $<0.100$ & 0.049 & 0.093 & 0.087 \\
\hline CEF2-FL-T & S-985b & 4.48 & 2.28 & 2.22 & $<0.100$ & 0.351 & 13.8 & $<0.100$ & 0.050 & 0.097 & 0.088 \\
\hline CEF2-FL-R & & & & & & not enough sample for analysis & & & & \\
\hline
\end{tabular}


Table A-42. Off-gas Filter Solids Total Solids

\begin{tabular}{ccc}
\hline Sample ID & Lab ID & Total Solids \\
\hline CEF2-FL-B & S-967 & $96.0 \%$ \\
\hline CEF2-FL-C & S-968 & $95.6 \%$ \\
\hline CEF2-FL-M & S-969 & $97.3 \%$ \\
\hline CEF2-FL-A & S-970 & $96.7 \%$ \\
\hline CEF2-FL-Q & S-971 & $97.0 \%$ \\
\hline CEF2-FL-G & S-972 & $98.3 \%$ \\
\hline CEF2-FL-D & S-973 & $96.7 \%$ \\
\hline CEF2-FL-E & S-974 & $98.1 \%$ \\
\hline CEF2-FL-F & S-975 & $98.5 \%$ \\
\hline CEF2-FL-H & S-976 & $99.0 \%$ \\
\hline CEF2-FL-K & S-977 & $97.7 \%$ \\
\hline CEF2-FL-L & S-978 & $96.9 \%$ \\
\hline CEF2-FL-N & S-979 & $96.2 \%$ \\
\hline CEF2-FL-P & S-980 & $95.6 \%$ \\
\hline CEF2-FL-O & S-981 & $95.6 \%$ \\
\hline CEF2-FL-U & S-982 & $95.7 \%$ \\
\hline CEF2-FL-J & S-983 & $95.5 \%$ \\
\hline CEF2-FL-S & S-984 & $96.3 \%$ \\
\hline CEF2-FL-T & S-985 & $95.9 \%$ \\
\hline CEF2-FL-R & not enough sample for analysis \\
\hline
\end{tabular}


Table A-43. ICP-AES Glass Analysis (wt\%) Set 1A

\begin{tabular}{|c|c|c|c|c|c|c|c|c|c|c|c|c|}
\hline Lab ID & $\begin{array}{c}\text { Collection } \\
\text { Date }\end{array}$ & $\begin{array}{c}\text { Collection } \\
\text { Time }\end{array}$ & Al & B & $\mathbf{B a}$ & $\mathrm{Ca}$ & $\mathrm{Cr}$ & $\mathbf{C u}$ & $\mathbf{F e}$ & $\mathbf{K}$ & $\mathbf{L i}$ & Mg \\
\hline S-896a & $2 / 26 / 2014$ & $8: 55$ & 4.96 & 1.60 & 0.052 & 0.427 & 0.074 & 0.063 & 7.38 & 0.119 & 2.39 & 0.343 \\
\hline S-896b & $2 / 26 / 2014$ & $8: 55$ & 5.02 & 1.57 & 0.053 & 0.435 & 0.075 & 0.058 & 7.44 & 0.118 & 2.35 & 0.344 \\
\hline S-903a & $2 / 28 / 2014$ & $15: 32$ & 5.10 & 1.54 & 0.054 & 0.443 & 0.075 & 0.056 & 7.46 & 0.119 & 2.33 & 0.351 \\
\hline S-903b & $2 / 28 / 2014$ & $15: 32$ & 5.00 & 1.56 & 0.052 & 0.416 & 0.069 & 0.053 & 7.41 & 0.117 & 2.33 & 0.341 \\
\hline S-908a & $3 / 2 / 2014$ & $6: 32$ & 5.01 & 1.55 & 0.052 & 0.421 & 0.073 & 0.136 & 7.43 & 0.119 & 2.31 & 0.343 \\
\hline S-908b & $3 / 2 / 2014$ & $6: 32$ & 5.04 & 1.55 & 0.052 & 0.428 & 0.074 & 0.130 & 7.47 & 0.119 & 2.33 & 0.345 \\
\hline S-915a & $3 / 4 / 2014$ & $4: 26$ & 4.84 & 1.51 & 0.052 & 0.408 & 0.070 & 0.050 & 7.39 & 0.116 & 2.31 & 0.340 \\
\hline S-915b & $3 / 4 / 2014$ & $4: 26$ & 4.86 & 1.58 & 0.052 & 0.411 & 0.076 & 0.060 & 7.43 & 0.117 & 2.34 & 0.342 \\
\hline S-927a & $3 / 8 / 2014$ & $6: 05$ & 4.85 & 1.54 & 0.054 & 0.454 & 0.080 & 0.191 & 7.58 & 0.118 & 2.32 & 0.349 \\
\hline S-927b & $3 / 8 / 2014$ & $6: 05$ & 4.91 & 1.55 & 0.054 & 0.451 & 0.075 & 0.197 & 7.68 & 0.119 & 2.30 & 0.352 \\
\hline S-931a & $3 / 9 / 2014$ & $7: 15$ & 4.75 & 1.55 & 0.052 & 0.402 & 0.076 & 0.095 & 7.46 & 0.114 & 2.31 & 0.338 \\
\hline S-931b & $3 / 9 / 2014$ & $7: 15$ & 4.71 & 1.52 & 0.053 & 0.409 & 0.075 & 0.124 & 7.39 & 0.116 & 2.32 & 0.339 \\
\hline S-932a & $3 / 10 / 2014$ & 8:00 & 4.82 & 1.51 & 0.053 & 0.418 & 0.074 & 0.052 & 7.53 & 0.117 & 2.31 & 0.348 \\
\hline S-932b & $3 / 10 / 2014$ & $8: 00$ & 4.86 & 1.53 & 0.053 & 0.422 & 0.074 & 0.053 & 7.59 & 0.117 & 2.34 & 0.348 \\
\hline S-934a & $3 / 11 / 2014$ & $9: 18$ & 4.93 & 1.50 & 0.053 & 0.424 & 0.074 & 0.102 & 7.75 & 0.118 & 2.27 & 0.348 \\
\hline S-934b & $3 / 11 / 2014$ & $9: 18$ & 4.81 & 1.50 & 0.053 & 0.424 & 0.074 & 0.116 & 7.41 & 0.117 & 2.27 & 0.347 \\
\hline S-937a & $3 / 12 / 2014$ & $10: 30$ & 4.77 & 1.50 & 0.053 & 0.416 & 0.074 & 0.191 & 7.52 & 0.119 & 2.28 & 0.345 \\
\hline S-937b & $3 / 12 / 2014$ & $10: 30$ & 4.81 & 1.49 & 0.053 & 0.414 & 0.073 & 0.206 & 7.60 & 0.118 & 2.30 & 0.345 \\
\hline S-940a & $3 / 13 / 2014$ & $10: 32$ & 4.90 & 1.48 & 0.054 & 0.425 & 0.078 & 0.063 & 7.67 & 0.120 & 2.26 & 0.349 \\
\hline S-940b & $3 / 13 / 2014$ & $10: 32$ & 4.94 & 1.45 & 0.057 & 0.497 & 0.073 & 0.066 & 7.73 & 0.118 & 2.27 & 0.354 \\
\hline S-942a & $3 / 14 / 2014$ & $9: 17$ & 4.80 & 1.44 & 0.053 & 0.420 & 0.074 & 0.071 & 7.53 & 0.121 & 2.23 & 0.348 \\
\hline S-942b & $3 / 14 / 2014$ & $9: 17$ & 4.78 & 1.46 & 0.053 & 0.419 & 0.076 & 0.073 & 7.54 & 0.121 & 2.29 & 0.348 \\
\hline S-945a & $3 / 15 / 2014$ & $9: 35$ & 4.80 & 1.51 & 0.053 & 0.410 & 0.072 & 0.092 & 7.50 & 0.121 & 2.30 & 0.345 \\
\hline S-945b & $3 / 15 / 2014$ & $9: 35$ & 4.83 & 1.50 & 0.053 & 0.408 & 0.077 & 0.093 & 7.53 & 0.121 & 2.30 & 0.344 \\
\hline
\end{tabular}


Table A-44. ICP-AES Glass Analysis Set 1B (wt\%)

\begin{tabular}{|c|c|c|c|c|c|c|c|c|c|c|c|c|}
\hline Lab ID & $\begin{array}{c}\text { Collection } \\
\text { Date }\end{array}$ & $\begin{array}{c}\text { Collection } \\
\text { Time }\end{array}$ & $\mathbf{M n}$ & $\mathbf{N a}$ & $\mathbf{N i}$ & $\mathbf{P}$ & $\mathbf{S}$ & Si & Sn & $\mathbf{T i}$ & Zn & $\mathbf{Z r}$ \\
\hline S-896a & $2 / 26 / 2014$ & $8: 55$ & 2.42 & 8.73 & 1.03 & $<0.100$ & 0.126 & 24.1 & $<0.100$ & 0.025 & 0.043 & 0.101 \\
\hline S-896b & 2/26/2014 & $8: 55$ & 2.44 & 8.69 & 1.04 & $<0.100$ & 0.130 & 23.6 & $<0.100$ & 0.025 & 0.042 & 0.101 \\
\hline S-903a & 2/28/2014 & $15: 32$ & 2.44 & 8.89 & 1.03 & $<0.100$ & 0.131 & 23.2 & $<0.100$ & 0.025 & 0.042 & 0.102 \\
\hline S-903b & $2 / 28 / 2014$ & $15: 32$ & 2.43 & 8.58 & 1.02 & $<0.100$ & 0.134 & 23.4 & $<0.100$ & 0.025 & 0.043 & 0.100 \\
\hline S-908a & $3 / 2 / 2014$ & $6: 32$ & 2.43 & 8.55 & 1.02 & $<0.100$ & 0.134 & 23.2 & $<0.100$ & 0.025 & 0.043 & 0.101 \\
\hline S-908b & $3 / 2 / 2014$ & $6: 32$ & 2.44 & 8.67 & 1.03 & $<0.100$ & 0.132 & 23.5 & $<0.100$ & 0.025 & 0.043 & 0.101 \\
\hline S-915a & $3 / 4 / 2014$ & $4: 26$ & 2.42 & 8.55 & 1.03 & $<0.100$ & 0.131 & 23.1 & $<0.100$ & 0.025 & 0.042 & 0.099 \\
\hline S-915b & $3 / 4 / 2014$ & $4: 26$ & 2.43 & 8.67 & 1.04 & $<0.100$ & 0.130 & 23.4 & $<0.100$ & 0.025 & 0.042 & 0.099 \\
\hline S-927a & $3 / 8 / 2014$ & $6: 05$ & 2.51 & 8.39 & 1.07 & $<0.100$ & 0.137 & 23.3 & $<0.100$ & 0.026 & 0.044 & 0.109 \\
\hline S-927b & $3 / 8 / 2014$ & $6: 05$ & 2.51 & 8.54 & 1.08 & $<0.100$ & 0.136 & 23.0 & $<0.100$ & 0.025 & 0.044 & 0.109 \\
\hline S-931a & $3 / 9 / 2014$ & $7: 15$ & 2.44 & 8.48 & 1.07 & $<0.100$ & 0.126 & 23.2 & $<0.100$ & 0.024 & 0.042 & 0.102 \\
\hline S-931b & $3 / 9 / 2014$ & $7: 15$ & 2.43 & 8.46 & 1.05 & $<0.100$ & 0.127 & 23.2 & $<0.100$ & 0.025 & 0.043 & 0.103 \\
\hline S-932a & $3 / 10 / 2014$ & 8:00 & 2.45 & 8.52 & 1.06 & $<0.100$ & 0.133 & 23.1 & $<0.100$ & 0.025 & 0.043 & 0.105 \\
\hline S-932b & $3 / 10 / 2014$ & 8:00 & 2.50 & 8.58 & 1.07 & $<0.100$ & 0.129 & 23.4 & $<0.100$ & 0.025 & 0.045 & 0.104 \\
\hline S-934a & $3 / 11 / 2014$ & $9: 18$ & 2.53 & 8.62 & 1.09 & $<0.100$ & 0.133 & 23.1 & $<0.100$ & 0.025 & 0.043 & 0.103 \\
\hline S-934b & $3 / 11 / 2014$ & $9: 18$ & 2.43 & 8.37 & 1.04 & $<0.100$ & 0.138 & 23.0 & $<0.100$ & 0.025 & 0.043 & 0.103 \\
\hline S-937a & $3 / 12 / 2014$ & $10: 30$ & 2.49 & 8.51 & 1.06 & $<0.100$ & 0.134 & 23.1 & $<0.100$ & 0.025 & 0.043 & 0.104 \\
\hline S-937b & $3 / 12 / 2014$ & $10: 30$ & 2.49 & 8.55 & 1.07 & $<0.100$ & 0.134 & 23.1 & $<0.100$ & 0.025 & 0.043 & 0.104 \\
\hline S-940a & $3 / 13 / 2014$ & $10: 32$ & 2.50 & 8.54 & 1.07 & $<0.100$ & 0.136 & 23.0 & $<0.100$ & 0.025 & 0.043 & 0.104 \\
\hline S-940b & $3 / 13 / 2014$ & $10: 32$ & 2.53 & 8.73 & 1.08 & $<0.100$ & 0.137 & 22.9 & $<0.100$ & 0.025 & 0.043 & 0.104 \\
\hline S-942a & $3 / 14 / 2014$ & $9: 17$ & 2.50 & 8.58 & 1.07 & $<0.100$ & 0.136 & 22.7 & $<0.100$ & 0.025 & 0.043 & 0.103 \\
\hline $\mathrm{S}-942 \mathrm{~b}$ & $3 / 14 / 2014$ & $9: 17$ & 2.47 & 8.54 & 1.06 & $<0.100$ & 0.134 & 23.0 & $<0.100$ & 0.025 & 0.043 & 0.103 \\
\hline S-945a & $3 / 15 / 2014$ & $9: 35$ & 2.45 & 8.48 & 1.04 & $<0.100$ & 0.131 & 23.3 & $<0.100$ & 0.025 & 0.043 & 0.104 \\
\hline $\mathrm{S}-945 \mathrm{~b}$ & $3 / 15 / 2014$ & $9: 35$ & 2.46 & 8.41 & 1.06 & $<0.100$ & 0.137 & 23.3 & $<0.100$ & 0.025 & 0.043 & 0.103 \\
\hline
\end{tabular}


Table A-45. ICP-AES Glass Analysis Set 2A (wt\%)

\begin{tabular}{|c|c|c|c|c|c|c|c|c|c|c|c|c|}
\hline Lab ID & $\begin{array}{c}\text { Collection } \\
\text { Date } \\
\end{array}$ & $\begin{array}{c}\text { Collection } \\
\text { Time } \\
\end{array}$ & Al & B & $\mathbf{B a}$ & $\mathrm{Ca}$ & $\mathrm{Cr}$ & $\mathrm{Cu}$ & $\mathbf{F e}$ & $\mathbf{K}$ & $\mathbf{L i}$ & Mg \\
\hline S-948a & $3 / 16 / 2014$ & 11:04 & 4.87 & 1.50 & 0.053 & 0.410 & 0.076 & 0.072 & 7.64 & 0.121 & 2.31 & 0.345 \\
\hline S-948b & $3 / 16 / 2014$ & 11:04 & 4.81 & 1.49 & 0.053 & 0.411 & 0.109 & 0.075 & 7.56 & 0.122 & 2.29 & 0.346 \\
\hline S-951a & $3 / 17 / 2014$ & $12: 25$ & 4.92 & 1.48 & 0.054 & 0.422 & 0.070 & 0.057 & 7.69 & 0.127 & 2.25 & 0.354 \\
\hline S-951b & $3 / 17 / 2014$ & $12: 25$ & 4.88 & 1.47 & 0.054 & 0.421 & 0.075 & 0.055 & 7.62 & 0.127 & 2.24 & 0.354 \\
\hline S-955a & $3 / 18 / 2014$ & $20: 37$ & 4.81 & 1.50 & 0.053 & 0.407 & 0.070 & 0.057 & 7.53 & 0.123 & 2.30 & 0.345 \\
\hline S-955b & $3 / 18 / 2014$ & $20: 37$ & 4.79 & 1.50 & 0.053 & 0.410 & 0.074 & 0.056 & 7.47 & 0.124 & 2.28 & 0.344 \\
\hline S-959a & $3 / 20 / 2014$ & $2: 48$ & 4.84 & 1.47 & 0.053 & 0.466 & 0.074 & 0.050 & 7.52 & 0.125 & 2.32 & 0.348 \\
\hline S-959b & $3 / 20 / 2014$ & $2: 48$ & 4.85 & 1.48 & 0.053 & 0.418 & 0.071 & 0.052 & 7.52 & 0.125 & 2.34 & 0.350 \\
\hline S-962a & $3 / 20 / 2014$ & $20: 13$ & 4.86 & 1.48 & 0.053 & 0.423 & 0.069 & 0.102 & 7.49 & 0.124 & 2.30 & 0.351 \\
\hline S-962b & $3 / 20 / 2014$ & $20: 13$ & 4.90 & 1.49 & 0.053 & 0.421 & 0.068 & 0.113 & 7.56 & 0.123 & 2.35 & 0.350 \\
\hline
\end{tabular}

Table A-46. ICP-AES Glass Analysis Set 2B (wt\%)

\begin{tabular}{ccccccccccccc}
\hline Lab ID & $\begin{array}{c}\text { Collection } \\
\text { Date }\end{array}$ & $\begin{array}{c}\text { Collection } \\
\text { Time }\end{array}$ & Mn & Na & Ni & $\mathbf{P}$ & $\mathbf{S}$ & Si & Sn & Ti & $\mathbf{Z n}$ & $\mathbf{Z r}$ \\
\hline S-948a & $3 / 16 / 2014$ & $11: 04$ & 2.51 & 8.67 & 1.07 & $<0.100$ & 0.135 & 23.3 & $<0.100$ & 0.025 & 0.043 & 0.101 \\
\hline S-948b & $3 / 16 / 2014$ & $11: 04$ & 2.49 & 8.63 & 1.33 & $<0.100$ & 0.137 & 23.2 & $<0.100$ & 0.025 & 0.044 & 0.101 \\
\hline S-951a & $3 / 17 / 2014$ & $12: 25$ & 2.51 & 8.63 & 1.06 & $<0.100$ & 0.145 & 22.8 & $<0.100$ & 0.025 & 0.044 & 0.105 \\
\hline S-951b & $3 / 17 / 2014$ & $12: 25$ & 2.48 & 8.66 & 1.05 & $<0.100$ & 0.138 & 22.8 & $<0.100$ & 0.025 & 0.044 & 0.105 \\
\hline S-955a & $3 / 18 / 2014$ & $20: 37$ & 2.47 & 8.50 & 1.05 & $<0.100$ & 0.135 & 23.3 & $<0.100$ & 0.025 & 0.043 & 0.102 \\
\hline S-955b & $3 / 18 / 2014$ & $20: 37$ & 2.47 & 8.44 & 1.09 & $<0.100$ & 0.137 & 23.1 & $<0.100$ & 0.025 & 0.043 & 0.102 \\
\hline S-959a & $3 / 20 / 2014$ & $2: 48$ & 2.48 & 8.55 & 1.05 & $<0.100$ & 0.139 & 23.1 & $<0.100$ & 0.025 & 0.044 & 0.102 \\
\hline S-959b & $3 / 20 / 2014$ & $2: 48$ & 2.47 & 8.62 & 1.06 & $<0.100$ & 0.138 & 23.4 & $<0.100$ & 0.025 & 0.043 & 0.102 \\
\hline S-962a & $3 / 20 / 2014$ & $20: 13$ & 2.50 & 8.49 & 1.04 & $<0.100$ & 0.140 & 23.1 & $<0.100$ & 0.025 & 0.043 & 0.103 \\
\hline S-962b & $3 / 20 / 2014$ & $20: 13$ & 2.49 & 8.46 & 1.05 & $<0.100$ & 0.139 & 23.7 & $<0.100$ & 0.025 & 0.043 & 0.103 \\
\hline
\end{tabular}


Table A-47. Glass REDOX Set 1

\begin{tabular}{|c|c|c|c|c|c|c|c|c|}
\hline Sample ID & Lab ID & $\begin{array}{c}\text { Collection } \\
\text { Date } \\
\end{array}$ & $\begin{array}{c}\text { Collection } \\
\text { Time } \\
\end{array}$ & $\mathrm{Fe}^{2+}$ & $\mathrm{Fe}^{3+}$ & $\sum \mathbf{F e}$ & $\mathrm{Fe}^{2+} / \mathrm{Fe}^{3+}$ & $\mathrm{Fe}^{2+} / \sum \mathrm{Fe}$ \\
\hline EA & EA & --- & --- & 0.082 & 0.368 & 0.450 & 0.223 & 0.182 \\
\hline CEF2-GL-001 (A) & S-896 & $2 / 26 / 2014$ & $8: 55$ & 0.027 & 0.471 & 0.498 & 0.057 & 0.054 \\
\hline CEF2-GL-001 (B) & S-896 & $2 / 26 / 2014$ & $8: 55$ & 0.026 & 0.470 & 0.496 & 0.055 & 0.052 \\
\hline CEF2-GL-003 (A) & S-897 & $2 / 26 / 2014$ & 19:05 & 0.023 & 0.433 & 0.456 & 0.053 & 0.050 \\
\hline CEF2-GL-003 (B) & S-897 & $2 / 26 / 2014$ & 19:05 & 0.024 & 0.432 & 0.456 & 0.056 & 0.053 \\
\hline CEF2-GL-004 (A) & S-898 & $2 / 26 / 2014$ & 23:00 & 0.016 & 0.412 & 0.428 & 0.039 & 0.037 \\
\hline CEF2-GL-004 (B) & S-898 & $2 / 26 / 2014$ & 23:00 & 0.018 & 0.410 & 0.428 & 0.044 & 0.042 \\
\hline CEF2-GL-006 (A) & S-899 & $2 / 27 / 2014$ & $7: 00$ & 0.020 & 0.463 & 0.483 & 0.043 & 0.041 \\
\hline CEF2-GL-006 (B) & S-899 & $2 / 27 / 2014$ & $7: 00$ & 0.019 & 0.463 & 0.482 & 0.041 & 0.039 \\
\hline CEF2-GL-008 (A) & S-900 & $2 / 27 / 2014$ & $15: 00$ & 0.016 & 0.497 & 0.513 & 0.032 & 0.031 \\
\hline CEF2-GL-008 (B) & S-900 & $2 / 27 / 2014$ & $15: 00$ & 0.016 & 0.497 & 0.513 & 0.032 & 0.031 \\
\hline CEF2-GL-010 (A) & S-901 & $2 / 27 / 2014$ & $23: 50$ & 0.020 & 0.477 & 0.497 & 0.042 & 0.040 \\
\hline CEF2-GL-010 (B) & S-901 & $2 / 27 / 2014$ & $23: 50$ & 0.019 & 0.477 & 0.496 & 0.040 & 0.038 \\
\hline CEF2-GL-012 (A) & S-902 & $2 / 28 / 2014$ & $8: 12$ & 0.018 & 0.517 & 0.535 & 0.035 & 0.034 \\
\hline CEF2-GL-012 (B) & S-902 & $2 / 28 / 2014$ & $8: 12$ & 0.019 & 0.517 & 0.536 & 0.037 & 0.035 \\
\hline CEF2-GL-013 (A) & S-903 & $2 / 28 / 2014$ & $15: 32$ & 0.015 & 0.611 & 0.626 & 0.025 & 0.024 \\
\hline CEF2-GL-013 (B) & S-903 & $2 / 28 / 2014$ & $15: 32$ & 0.015 & 0.613 & 0.628 & 0.024 & 0.024 \\
\hline CEF2-GL-014 (A) & S-904 & $2 / 28 / 2014$ & $21: 25$ & 0.012 & 0.494 & 0.506 & 0.024 & 0.024 \\
\hline CEF2-GL-014 (B) & S-904 & $2 / 28 / 2014$ & $21: 25$ & 0.012 & 0.495 & 0.507 & 0.024 & 0.024 \\
\hline CEF2-GL-016 (A) & S-905 & $3 / 1 / 2014$ & $5: 25$ & 0.011 & 0.468 & 0.479 & 0.024 & 0.023 \\
\hline CEF2-GL-016 (B) & S-905 & $3 / 1 / 2014$ & $5: 25$ & 0.012 & 0.467 & 0.479 & 0.026 & 0.025 \\
\hline CEF2-GL-018 (A) & S-906 & $3 / 1 / 2014$ & $13: 47$ & 0.012 & 0.603 & 0.615 & 0.020 & 0.020 \\
\hline CEF2-GL-018 (B) & S-906 & $3 / 1 / 2014$ & $13: 47$ & 0.012 & 0.602 & 0.614 & 0.020 & 0.020 \\
\hline CEF2-GL-020 (A) & S-907 & $3 / 1 / 2014$ & $21: 30$ & 0.013 & 0.555 & 0.568 & 0.023 & 0.023 \\
\hline CEF2-GL-020 (B) & S-907 & $3 / 1 / 2014$ & $21: 30$ & 0.015 & 0.554 & 0.569 & 0.027 & 0.026 \\
\hline CEF2-GL-022 (A) & S-908 & $3 / 2 / 2014$ & $6: 32$ & 0.010 & 0.615 & 0.625 & 0.016 & 0.016 \\
\hline CEF2-GL-022 (B) & S-908 & $3 / 2 / 2014$ & $6: 32$ & 0.010 & 0.615 & 0.625 & 0.016 & 0.016 \\
\hline
\end{tabular}


Table A-48. Glass REDOX Set 2

\begin{tabular}{|c|c|c|c|c|c|c|c|c|}
\hline Sample ID & Lab ID & $\begin{array}{c}\text { Collection } \\
\text { Date }\end{array}$ & $\begin{array}{c}\text { Collection } \\
\text { Time }\end{array}$ & $\mathrm{Fe}^{2+}$ & $\mathrm{Fe}^{3+}$ & $\sum \mathrm{Fe}$ & $\mathrm{Fe}^{2+} / \mathrm{Fe}^{3+}$ & $\mathrm{Fe}^{2+} / \sum \mathrm{Fe}$ \\
\hline CEF2-GL-024 (A) & S-909 & $3 / 2 / 2014$ & $14: 20$ & 0.010 & 0.594 & 0.604 & 0.017 & 0.017 \\
\hline CEF2-GL-024 (B) & S-909 & $3 / 2 / 2014$ & $14: 20$ & 0.010 & 0.594 & 0.604 & 0.017 & 0.017 \\
\hline CEF2-GL-026 (A) & S-910 & $3 / 2 / 2014$ & $22: 40$ & $<0.010$ & 0.575 & 0.575 & All Fe $\mathrm{Fe}^{3+}$ & All $\mathrm{Fe}^{3+}$ \\
\hline CEF2-GL-026 (B) & S-910 & $3 / 2 / 2014$ & $22: 40$ & $<0.010$ & 0.575 & 0.575 & All $\mathrm{Fe}^{3+}$ & All $\mathrm{Fe}^{3+}$ \\
\hline CEF2-GL-027 (A) & S-911 & $3 / 3 / 2014$ & $2: 41$ & $<0.010$ & 0.490 & 0.490 & All $\mathrm{Fe}^{3+}$ & All $\mathrm{Fe}^{3+}$ \\
\hline CEF2-GL-027 (B) & S-911 & $3 / 3 / 2014$ & $2: 41$ & $<0.010$ & 0.492 & 0.492 & All $\mathrm{Fe}^{3+}$ & All $\mathrm{Fe}^{3+}$ \\
\hline CEF2-GL-029 (A) & S-912 & $3 / 3 / 2014$ & $10: 36$ & $<0.010$ & 0.580 & 0.580 & All $\mathrm{Fe}^{3+}$ & All $\mathrm{Fe}^{3+}$ \\
\hline CEF2-GL-029 (B) & S-912 & $3 / 3 / 2014$ & $10: 36$ & $<0.010$ & 0.582 & 0.582 & All $\mathrm{Fe}^{3+}$ & All $\mathrm{Fe}^{3+}$ \\
\hline CEF2-GL-031 (A) & S-913 & $3 / 3 / 2014$ & $20: 00$ & $<0.010$ & 0.526 & 0.526 & All $\mathrm{Fe}^{3+}$ & All $\mathrm{Fe}^{3+}$ \\
\hline CEF2-GL-031 (B) & S-913 & $3 / 3 / 2014$ & $20: 00$ & $<0.010$ & 0.527 & 0.527 & All $\mathrm{Fe}^{3+}$ & All $\mathrm{Fe}^{3+}$ \\
\hline CEF2-GL-032 (A) & S-914 & $3 / 4 / 2014$ & $0: 15$ & $<0.010$ & 0.603 & 0.603 & All $\mathrm{Fe}^{3+}$ & All $\mathrm{Fe}^{3+}$ \\
\hline CEF2-GL-032 (B) & S-914 & $3 / 4 / 2014$ & $0: 15$ & $<0.010$ & 0.604 & 0.604 & All $\mathrm{Fe}^{3+}$ & All $\mathrm{Fe}^{3+}$ \\
\hline CEF2-GL-033 (A) & S-915 & $3 / 4 / 2014$ & $4: 26$ & $<0.010$ & 0.535 & 0.535 & All $\mathrm{Fe}^{3+}$ & All $\mathrm{Fe}^{3+}$ \\
\hline CEF2-GL-033 (B) & S-915 & $3 / 4 / 2014$ & $4: 26$ & $<0.010$ & 0.536 & 0.536 & All $\mathrm{Fe}^{3+}$ & All $\mathrm{Fe}^{3+}$ \\
\hline CEF2-GL-034 (A) & S-916 & $3 / 4 / 2014$ & $8: 33$ & $<0.010$ & 0.517 & 0.517 & All $\mathrm{Fe}^{3+}$ & All $\mathrm{Fe}^{3+}$ \\
\hline CEF2-GL-034 (B) & S-916 & $3 / 4 / 2014$ & $8: 33$ & $<0.010$ & 0.516 & 0.516 & All $\mathrm{Fe}^{3+}$ & All $\mathrm{Fe}^{3+}$ \\
\hline CEF2-GL-036 (A) & S-917 & $3 / 4 / 2014$ & $21: 14$ & $<0.010$ & 0.512 & 0.512 & All $\mathrm{Fe}^{3+}$ & All $\mathrm{Fe}^{3+}$ \\
\hline CEF2-GL-036 (B) & S-917 & $3 / 4 / 2014$ & $21: 14$ & $<0.010$ & 0.510 & 0.510 & All Fe $\mathrm{Fe}^{3+}$ & All Fe $\mathrm{Fe}^{3+}$ \\
\hline CEF2-GL-038 (A) & S-918 & $3 / 5 / 2014$ & $5: 10$ & $<0.010$ & 0.545 & 0.545 & All $\mathrm{Fe}^{3+}$ & All $\mathrm{Fe}^{3+}$ \\
\hline CEF2-GL-038 (B) & S-918 & $3 / 5 / 2014$ & $5: 10$ & $<0.010$ & 0.547 & 0.547 & All $\mathrm{Fe}^{3+}$ & All $\mathrm{Fe}^{3+}$ \\
\hline CEF2-GL-040 (A) & S-919 & $3 / 5 / 2014$ & $13: 26$ & $<0.010$ & 0.495 & 0.495 & All Fe $\mathrm{Fe}^{3+}$ & All $\mathrm{Fe}^{3+}$ \\
\hline CEF2-GL-040 (B) & S-919 & $3 / 5 / 2014$ & $13: 26$ & $<0.010$ & 0.496 & 0.496 & All $\mathrm{Fe}^{3+}$ & All $\mathrm{Fe}^{3+}$ \\
\hline
\end{tabular}


Table A-49. Glass REDOX Set 3

\begin{tabular}{|c|c|c|c|c|c|c|c|c|}
\hline Sample ID & Lab ID & $\begin{array}{c}\text { Collection } \\
\text { Date }\end{array}$ & $\begin{array}{c}\text { Collection } \\
\text { Time } \\
\end{array}$ & $\mathrm{Fe}^{2+}$ & $\mathrm{Fe}^{3+}$ & $\sum \mathbf{F e}$ & $\mathrm{Fe}^{2+} / \mathrm{Fe}^{3+}$ & $\mathrm{Fe}^{2+} / \sum \mathrm{Fe}$ \\
\hline CEF2-GL-042 (A) & S-920 & $3 / 5 / 2014$ & $21: 32$ & $<0.010$ & 0.512 & 0.512 & All Fe ${ }^{3+}$ & All Fe $\mathrm{Fe}^{3+}$ \\
\hline CEF2-GL-042 (B) & S-920 & $3 / 5 / 2014$ & $21: 32$ & $<0.010$ & 0.510 & 0.510 & All Fe ${ }^{3+}$ & All Fe ${ }^{3+}$ \\
\hline CEF2-GL-044 (A) & S-921 & $3 / 6 / 2014$ & $5: 30$ & $<0.010$ & 0.467 & 0.467 & All Fe ${ }^{3+}$ & All Fe $\mathrm{Fe}^{3+}$ \\
\hline CEF2-GL-044 (B) & S-921 & $3 / 6 / 2014$ & $5: 30$ & $<0.010$ & 0.464 & 0.464 & All Fe ${ }^{3+}$ & All Fe ${ }^{3+}$ \\
\hline CEF2-GL-046 (A) & S-922 & $3 / 6 / 2014$ & $13: 28$ & $<0.010$ & 0.523 & 0.523 & All Fe ${ }^{3+}$ & All Fe ${ }^{3+}$ \\
\hline CEF2-GL-046 (B) & S-922 & $3 / 6 / 2014$ & $13: 28$ & $<0.010$ & 0.523 & 0.523 & All Fe ${ }^{3+}$ & All Fe ${ }^{3+}$ \\
\hline CEF2-GL-048 (A) & S-923 & $3 / 6 / 2014$ & $21: 30$ & $<0.010$ & 0.504 & 0.504 & All Fe ${ }^{3+}$ & All $\mathrm{Fe}^{3+}$ \\
\hline CEF2-GL-048 (B) & S-923 & $3 / 6 / 2014$ & $21: 30$ & $<0.010$ & 0.504 & 0.504 & All Fe ${ }^{3+}$ & All Fe $\mathrm{Fe}^{3+}$ \\
\hline CEF2-GL-050 (A) & S-924 & $3 / 7 / 2014$ & $5: 32$ & $<0.010$ & 0.552 & 0.552 & All Fe ${ }^{3+}$ & All Fe ${ }^{3+}$ \\
\hline CEF2-GL-050 (B) & S-924 & $3 / 7 / 2014$ & $5: 32$ & $<0.010$ & 0.551 & 0.551 & All Fe ${ }^{3+}$ & All Fe ${ }^{3+}$ \\
\hline CEF2-GL-052 (A) & S-925 & $3 / 7 / 2014$ & $14: 07$ & $<0.010$ & 0.489 & 0.489 & All Fe ${ }^{3+}$ & All Fe $\mathrm{Fe}^{3+}$ \\
\hline CEF2-GL-052 (B) & S-925 & $3 / 7 / 2014$ & $14: 07$ & $<0.010$ & 0.490 & 0.490 & All Fe ${ }^{3+}$ & All Fe ${ }^{3+}$ \\
\hline CEF2-GL-054 (A) & S-926 & $3 / 7 / 2014$ & $22: 07$ & $<0.010$ & 0.539 & 0.539 & All Fe $e^{3+}$ & All Fe ${ }^{3+}$ \\
\hline CEF2-GL-054 (B) & S-926 & $3 / 7 / 2014$ & $22: 07$ & $<0.010$ & 0.540 & 0.540 & All Fe ${ }^{3+}$ & All Fe ${ }^{3+}$ \\
\hline CEF2-GL-056 (A) & S-927 & $3 / 8 / 2014$ & $6: 05$ & $<0.010$ & 0.488 & 0.488 & All Fe ${ }^{3+}$ & All Fe ${ }^{3+}$ \\
\hline CEF2-GL-056 (B) & S-927 & $3 / 8 / 2014$ & $6: 05$ & $<0.010$ & 0.490 & 0.490 & All Fe ${ }^{3+}$ & All Fe $\mathrm{Fe}^{3+}$ \\
\hline CEF2-GL-058 (A) & S-928 & $3 / 8 / 2014$ & $14: 06$ & $<0.010$ & 0.451 & 0.451 & All Fe ${ }^{3+}$ & All Fe ${ }^{3+}$ \\
\hline CEF2-GL-058 (B) & S-928 & $3 / 8 / 2014$ & $14: 06$ & $<0.010$ & 0.451 & 0.451 & All Fe ${ }^{3+}$ & All Fe ${ }^{3+}$ \\
\hline CEF2-GL-060 (A) & S-929 & $3 / 8 / 2014$ & $22: 09$ & $<0.010$ & 0.526 & 0.526 & All Fe ${ }^{3+}$ & All Fe $\mathrm{Fe}^{3+}$ \\
\hline CEF2-GL-060 (B) & S-929 & $3 / 8 / 2014$ & $22: 09$ & $<0.010$ & 0.527 & 0.527 & All Fe ${ }^{3+}$ & All Fe $\mathrm{Fe}^{3+}$ \\
\hline CEF2-GL-061 (A) & S-930 & $3 / 9 / 2014$ & $3: 30$ & $<0.010$ & 0.479 & 0.479 & All Fe ${ }^{3+}$ & All Fe $\mathrm{Fe}^{3+}$ \\
\hline CEF2-GL-061 (B) & S-930 & $3 / 9 / 2014$ & $3: 30$ & $<0.010$ & 0.476 & 0.476 & All Fe ${ }^{3+}$ & All Fe ${ }^{3+}$ \\
\hline
\end{tabular}


Table A-50. Glass REDOX Set 4

\begin{tabular}{|c|c|c|c|c|c|c|c|c|}
\hline Sample ID & Lab ID & $\begin{array}{c}\text { Collection } \\
\text { Date }\end{array}$ & $\begin{array}{c}\text { Collection } \\
\text { Time } \\
\end{array}$ & $\mathrm{Fe}^{2+}$ & $\mathrm{Fe}^{3+}$ & $\sum \mathbf{F e}$ & $\mathrm{Fe}^{2+} / \mathrm{Fe}^{3+}$ & $\mathrm{Fe}^{2+} / \sum \mathrm{Fe}$ \\
\hline EA & EA & --- & -- & 0.083 & 0.365 & 0.448 & 0.227 & 0.185 \\
\hline CEF2-GL-062 (A) & S-931 & $3 / 9 / 2014$ & $7: 15$ & $<0.010$ & 0.545 & 0.545 & All Fe ${ }^{3+}$ & All Fe ${ }^{3+}$ \\
\hline CEF2-GL-062 (B) & S-931 & $3 / 9 / 2014$ & $7: 15$ & $<0.010$ & 0.548 & 0.548 & All Fe $\mathrm{Fe}^{3+}$ & All Fe $\mathrm{Fe}^{3+}$ \\
\hline CEF2-GL-063 (A) & $\mathrm{S}-932$ & $3 / 10 / 2014$ & $8: 00$ & $<0.010$ & 0.544 & 0.544 & All Fe $\mathrm{Fe}^{3+}$ & All Fe $\mathrm{Fe}^{3+}$ \\
\hline CEF2-GL-063 (B) & $\mathrm{S}-932$ & $3 / 10 / 2014$ & $8: 00$ & $<0.010$ & 0.545 & 0.545 & All $\mathrm{Fe}^{3+}$ & All Fe ${ }^{3+}$ \\
\hline CEF2-GL-064 (A) & S-933 & $3 / 10 / 2014$ & $11: 59$ & $<0.010$ & 0.460 & 0.460 & All $\mathrm{Fe}^{3+}$ & All Fe $\mathrm{Fe}^{3+}$ \\
\hline CEF2-GL-064 (B) & S-933 & $3 / 10 / 2014$ & $11: 59$ & $<0.010$ & 0.459 & 0.459 & All Fe $\mathrm{Fe}^{3+}$ & All $\mathrm{Fe}^{3+}$ \\
\hline CEF2-GL-065 (A) & S-934 & $3 / 11 / 2014$ & $9: 18$ & $<0.010$ & 0.457 & 0.457 & All Fe $\mathrm{Fe}^{3+}$ & All Fe $\mathrm{Fe}^{3+}$ \\
\hline CEF2-GL-065 (B) & S-934 & $3 / 11 / 2014$ & $9: 18$ & $<0.010$ & 0.458 & 0.458 & All $\mathrm{Fe}^{3+}$ & All $\mathrm{Fe}^{3+}$ \\
\hline CEF2-GL-067 (A) & S-935 & $3 / 11 / 2014$ & $17: 20$ & $<0.010$ & 0.475 & 0.475 & All Fe $\mathrm{Fe}^{3+}$ & All Fe ${ }^{3+}$ \\
\hline CEF2-GL-067 (B) & S-935 & $3 / 11 / 2014$ & $17: 20$ & $<0.010$ & 0.477 & 0.477 & All $\mathrm{Fe}^{3+}$ & All Fe ${ }^{3+}$ \\
\hline CEF2-GL-069 (A) & S-936 & $3 / 12 / 2014$ & $2: 30$ & $<0.010$ & 0.509 & 0.509 & All $\mathrm{Fe}^{3+}$ & All Fe $\mathrm{Fe}^{3+}$ \\
\hline CEF2-GL-069 (B) & S-936 & $3 / 12 / 2014$ & $2: 30$ & $<0.010$ & 0.509 & 0.509 & All Fe $\mathrm{Fe}^{3+}$ & All Fe $\mathrm{Fe}^{3+}$ \\
\hline CEF2-GL-071 (A) & S-937 & $3 / 12 / 2014$ & $10: 30$ & $<0.010$ & 0.437 & 0.437 & All Fe $\mathrm{Fe}^{3+}$ & All Fe $\mathrm{Fe}^{3+}$ \\
\hline CEF2-GL-071 (B) & S-937 & $3 / 12 / 2014$ & $10: 30$ & $<0.010$ & 0.440 & 0.440 & All Fe $\mathrm{Fe}^{3+}$ & All Fe ${ }^{3+}$ \\
\hline CEF2-GL-073 (A) & S-938 & $3 / 12 / 2014$ & $18: 30$ & $<0.010$ & 0.461 & 0.461 & All $\mathrm{Fe}^{3+}$ & All $\mathrm{Fe}^{3+}$ \\
\hline CEF2-GL-073 (B) & S-938 & $3 / 12 / 2014$ & $18: 30$ & $<0.010$ & 0.462 & 0.462 & All $\mathrm{Fe}^{3+}$ & All Fe $\mathrm{Fe}^{3+}$ \\
\hline CEF2-GL-075 (A) & S-939 & $3 / 13 / 2014$ & $2: 40$ & $<0.010$ & 0.458 & 0.458 & All Fe $\mathrm{Fe}^{3+}$ & All $\mathrm{Fe}^{3+}$ \\
\hline CEF2-GL-075 (B) & S-939 & $3 / 13 / 2014$ & $2: 40$ & $<0.010$ & 0.457 & 0.457 & All Fe $\mathrm{Fe}^{3+}$ & All Fe $\mathrm{Fe}^{3+}$ \\
\hline CEF2-GL-077 (A) & S-940 & $3 / 13 / 2014$ & $10: 32$ & $<0.010$ & 0.484 & 0.484 & All $\mathrm{Fe}^{3+}$ & All Fe ${ }^{3+}$ \\
\hline CEF2-GL-077 (B) & S-940 & $3 / 13 / 2014$ & $10: 32$ & $<0.010$ & 0.485 & 0.485 & All $\mathrm{Fe}^{3+}$ & All $\mathrm{Fe}^{3+}$ \\
\hline CEF2-GL-079 (A) & S-941 & $3 / 13 / 2014$ & $18: 35$ & $<0.010$ & 0.487 & 0.487 & All Fe $\mathrm{Fe}^{3+}$ & All Fe $\mathrm{Fe}^{3+}$ \\
\hline CEF2-GL-079 (B) & S-941 & $3 / 13 / 2014$ & $18: 35$ & $<0.010$ & 0.486 & 0.486 & All Fe $\mathrm{Fe}^{3+}$ & All Fe ${ }^{3+}$ \\
\hline
\end{tabular}


Table A-51. Glass REDOX Set 5

\begin{tabular}{|c|c|c|c|c|c|c|c|c|}
\hline Sample ID & Lab ID & $\begin{array}{c}\text { Collection } \\
\text { Date }\end{array}$ & $\begin{array}{c}\text { Collection } \\
\text { Time }\end{array}$ & $\mathrm{Fe}^{2+}$ & $\mathrm{Fe}^{3+}$ & $\sum \mathbf{F e}$ & $\mathrm{Fe}^{2+} / \mathrm{Fe}^{3+}$ & $\mathrm{Fe}^{2+} / \sum \mathbf{F e}$ \\
\hline CEF2-GL-081 (A) & S-942 & $3 / 14 / 2014$ & $9: 17$ & $<0.010$ & 0.479 & 0.479 & All $\mathrm{Fe}^{3+}$ & All $\mathrm{Fe}^{3+}$ \\
\hline CEF2-GL-081 (B) & S-942 & $3 / 14 / 2014$ & $9: 17$ & $<0.010$ & 0.480 & 0.480 & All $\mathrm{Fe}^{3+}$ & All $\mathrm{Fe}^{3+}$ \\
\hline CEF2-GL-083 (A) & S-943 & $3 / 14 / 2014$ & $17: 30$ & $<0.010$ & 0.467 & 0.467 & All $\mathrm{Fe}^{3+}$ & All $\mathrm{Fe}^{3+}$ \\
\hline CEF2-GL-083 (B) & S-943 & $3 / 14 / 2014$ & $17: 30$ & $<0.010$ & 0.467 & 0.467 & All $\mathrm{Fe}^{3+}$ & All $\mathrm{Fe}^{3+}$ \\
\hline CEF2-GL-085 (A) & S-944 & $3 / 15 / 2014$ & $1: 25$ & $<0.010$ & 0.539 & 0.539 & All $\mathrm{Fe}^{3+}$ & All $\mathrm{Fe}^{3+}$ \\
\hline CEF2-GL-085 (B) & S-944 & $3 / 15 / 2014$ & $1: 25$ & $<0.010$ & 0.541 & 0.541 & All Fe ${ }^{3+}$ & All $\mathrm{Fe}^{3+}$ \\
\hline CEF2-GL-087 (A) & S-945 & $3 / 15 / 2014$ & $9: 35$ & $<0.010$ & 0.451 & 0.451 & All $\mathrm{Fe}^{3+}$ & All $\mathrm{Fe}^{3+}$ \\
\hline CEF2-GL-087 (B) & S-945 & $3 / 15 / 2014$ & $9: 35$ & $<0.010$ & 0.452 & 0.452 & All $\mathrm{Fe}^{3+}$ & All $\mathrm{Fe}^{3+}$ \\
\hline CEF2-GL-089 (A) & S-946 & $3 / 15 / 2014$ & $18: 24$ & $<0.010$ & 0.497 & 0.497 & All $\mathrm{Fe}^{3+}$ & All $\mathrm{Fe}^{3+}$ \\
\hline CEF2-GL-089 (B) & S-946 & $3 / 15 / 2014$ & $18: 24$ & $<0.010$ & 0.498 & 0.498 & All $\mathrm{Fe}^{3+}$ & All $\mathrm{Fe}^{3+}$ \\
\hline CEF2-GL-091 (A) & S-947 & $3 / 16 / 2014$ & $2: 32$ & $<0.010$ & 0.494 & 0.494 & All $\mathrm{Fe}^{3+}$ & All $\mathrm{Fe}^{3+}$ \\
\hline CEF2-GL-091 (B) & S-947 & $3 / 16 / 2014$ & $2: 32$ & $<0.010$ & 0.495 & 0.495 & All $\mathrm{Fe}^{3+}$ & All $\mathrm{Fe}^{3+}$ \\
\hline CEF2-GL-093 (A) & S-948 & $3 / 16 / 2014$ & 11:04 & $<0.010$ & 0.468 & 0.468 & All $\mathrm{Fe}^{3+}$ & All $\mathrm{Fe}^{3+}$ \\
\hline CEF2-GL-093 (B) & $\mathrm{S}-948$ & $3 / 16 / 2014$ & 11:04 & $<0.010$ & 0.468 & 0.468 & All $\mathrm{Fe}^{3+}$ & All $\mathrm{Fe}^{3+}$ \\
\hline CEF2-GL-094 (A) & S-949 & $3 / 16 / 2014$ & $18: 23$ & $<0.010$ & 0.514 & 0.514 & All Fe $\mathrm{Fe}^{3+}$ & All $\mathrm{Fe}^{3+}$ \\
\hline CEF2-GL-094 (B) & S-949 & $3 / 16 / 2014$ & $18: 23$ & $<0.010$ & 0.515 & 0.515 & All $\mathrm{Fe}^{3+}$ & All $\mathrm{Fe}^{3+}$ \\
\hline CEF2-GL-096 (A) & S-950 & $3 / 17 / 2014$ & $4: 27$ & $<0.010$ & 0.471 & 0.471 & All $\mathrm{Fe}^{3+}$ & All $\mathrm{Fe}^{3+}$ \\
\hline CEF2-GL-096 (B) & $\mathrm{S}-950$ & $3 / 17 / 2014$ & $4: 27$ & $<0.010$ & 0.473 & 0.473 & All $\mathrm{Fe}^{3+}$ & All $\mathrm{Fe}^{3+}$ \\
\hline CEF2-GL-098 (A) & S-951 & $3 / 17 / 2014$ & $12: 25$ & $<0.010$ & 0.573 & 0.573 & All $\mathrm{Fe}^{3+}$ & All $\mathrm{Fe}^{3+}$ \\
\hline CEF2-GL-098 (B) & S-951 & $3 / 17 / 2014$ & $12: 25$ & $<0.010$ & 0.572 & 0.572 & All $\mathrm{Fe}^{3+}$ & All $\mathrm{Fe}^{3+}$ \\
\hline CEF2-GL-100 (A) & S-952 & $3 / 17 / 2014$ & $20: 31$ & $<0.010$ & 0.496 & 0.496 & All $\mathrm{Fe}^{3+}$ & All $\mathrm{Fe}^{3+}$ \\
\hline CEF2-GL-100 (B) & S-952 & $3 / 17 / 2014$ & $20: 31$ & $<0.010$ & 0.496 & 0.496 & All $\mathrm{Fe}^{3+}$ & All $\mathrm{Fe}^{3+}$ \\
\hline
\end{tabular}


Table A-52. Glass REDOX Set 6

\begin{tabular}{|c|c|c|c|c|c|c|c|c|}
\hline Sample ID & Lab ID & $\begin{array}{c}\text { Collection } \\
\text { Date } \\
\end{array}$ & $\begin{array}{c}\text { Collection } \\
\text { Time } \\
\end{array}$ & $\mathrm{Fe}^{2+}$ & $\mathrm{Fe}^{3+}$ & $\sum \mathbf{F e}$ & $\mathrm{Fe}^{2+} / \mathrm{Fe}^{3+}$ & $\mathrm{Fe}^{2+} / \sum \mathrm{Fe}$ \\
\hline CEF2-GL-102 (A) & S-953 & $3 / 18 / 2014$ & $4: 40$ & $<0.010$ & 0.573 & 0.573 & All Fe ${ }^{3+}$ & All Fe ${ }^{3+}$ \\
\hline CEF2-GL-102 (B) & S-953 & $3 / 18 / 2014$ & $4: 40$ & $<0.010$ & 0.572 & 0.572 & All Fe ${ }^{3+}$ & All Fe ${ }^{3+}$ \\
\hline CEF2-GL-104 (A) & S-954 & $3 / 18 / 2014$ & $12: 25$ & $<0.010$ & 0.493 & 0.493 & All Fe ${ }^{3+}$ & All Fe ${ }^{3+}$ \\
\hline CEF2-GL-104 (B) & S-954 & $3 / 18 / 2014$ & $12: 25$ & $<0.010$ & 0.494 & 0.494 & All Fe ${ }^{3+}$ & All Fe ${ }^{3+}$ \\
\hline CEF2-GL-106 (A) & S-955 & $3 / 18 / 2014$ & $20: 37$ & $<0.010$ & 0.533 & 0.533 & All Fe ${ }^{3+}$ & All Fe ${ }^{3+}$ \\
\hline CEF2-GL-106 (B) & S-955 & $3 / 18 / 2014$ & $20: 37$ & $<0.010$ & 0.534 & 0.534 & All Fe ${ }^{3+}$ & All Fe ${ }^{3+}$ \\
\hline CEF2-GL-108 (A) & S-956 & $3 / 19 / 2014$ & $6: 25$ & $<0.010$ & 0.449 & 0.449 & All Fe ${ }^{3+}$ & All Fe ${ }^{3+}$ \\
\hline CEF2-GL-108 (B) & S-956 & $3 / 19 / 2014$ & $6: 25$ & $<0.010$ & 0.450 & 0.450 & All Fe $\mathrm{Fe}^{3+}$ & All Fe ${ }^{3+}$ \\
\hline CEF2-GL-110 (A) & S-957 & $3 / 19 / 2014$ & $14: 28$ & $<0.010$ & 0.470 & 0.470 & All Fe ${ }^{3+}$ & All Fe $\mathrm{Fe}^{3+}$ \\
\hline CEF2-GL-110 (B) & S-957 & $3 / 19 / 2014$ & $14: 28$ & $<0.010$ & 0.472 & 0.472 & All Fe ${ }^{3+}$ & All Fe ${ }^{3+}$ \\
\hline CEF2-GL-112 (A) & S-958 & $3 / 19 / 2014$ & $22: 07$ & $<0.010$ & 0.480 & 0.480 & All Fe ${ }^{3+}$ & All Fe ${ }^{3+}$ \\
\hline CEF2-GL-112 (B) & S-958 & $3 / 19 / 2014$ & $22: 07$ & $<0.010$ & 0.481 & 0.481 & All Fe ${ }^{3+}$ & All Fe $\mathrm{Fe}^{3+}$ \\
\hline CEF2-GL-113 (A) & S-959 & $3 / 20 / 2014$ & $2: 48$ & $<0.010$ & 0.476 & 0.476 & All Fe $\mathrm{Fe}^{3+}$ & All Fe ${ }^{3+}$ \\
\hline CEF2-GL-113 (B) & S-959 & $3 / 20 / 2014$ & $2: 48$ & $<0.010$ & 0.478 & 0.478 & All Fe $e^{3+}$ & All $\mathrm{Fe}^{3+}$ \\
\hline CEF2-GL-114 (A) & S-960 & $3 / 20 / 2014$ & $6: 48$ & $<0.010$ & 0.456 & 0.456 & All Fe ${ }^{3+}$ & All Fe $\mathrm{Fe}^{3+}$ \\
\hline CEF2-GL-114 (B) & S-960 & $3 / 20 / 2014$ & $6: 48$ & $<0.010$ & 0.459 & 0.459 & All $\mathrm{Fe}^{3+}$ & $\mathrm{All} \mathrm{Fe} \mathrm{Fe}^{3+}$ \\
\hline CEF2-GL-116 (A) & S-961 & $3 / 20 / 2014$ & $14: 25$ & $<0.010$ & 0.442 & 0.442 & All Fe ${ }^{3+}$ & All Fe $\mathrm{Fe}^{3+}$ \\
\hline CEF2-GL-116 (B) & S-961 & $3 / 20 / 2014$ & $14: 25$ & $<0.010$ & 0.445 & 0.445 & All Fe ${ }^{3+}$ & All Fe $\mathrm{Fe}^{3+}$ \\
\hline CEF2-GL-117 (A) & S-962 & $3 / 20 / 2014$ & $20: 13$ & $<0.010$ & 0.518 & 0.518 & All Fe ${ }^{3+}$ & All Fe ${ }^{3+}$ \\
\hline CEF2-GL-117 (B) & S-962 & $3 / 20 / 2014$ & $20: 13$ & $<0.010$ & 0.517 & 0.517 & All Fe $\mathrm{Fe}^{3+}$ & All Fe $\mathrm{Fe}^{3+}$ \\
\hline CEF2-GL-118 (A) & S-963 & $3 / 21 / 2014$ & $1: 35$ & $<0.010$ & 0.529 & 0.529 & All Fe $\mathrm{Fe}^{3+}$ & All Fe ${ }^{3+}$ \\
\hline CEF2-GL-118 (B) & S-963 & $3 / 21 / 2014$ & $1: 35$ & $<0.010$ & 0.528 & 0.528 & All Fe ${ }^{3+}$ & All Fe $\mathrm{Fe}^{3+}$ \\
\hline
\end{tabular}


Table A-53. Glass REDOX Set 7

\begin{tabular}{|c|c|c|c|c|c|c|c|c|}
\hline Sample ID & Lab ID & $\begin{array}{c}\text { Collection } \\
\text { Date }\end{array}$ & $\begin{array}{c}\text { Collection } \\
\text { Time } \\
\end{array}$ & $\mathrm{Fe}^{2+}$ & $\mathrm{Fe}^{3+}$ & $\sum \mathbf{F e}$ & $\mathrm{Fe}^{2+} / \mathrm{Fe}^{3+}$ & $\mathrm{Fe}^{2+} / \sum \mathrm{Fe}$ \\
\hline CEF2-GL-119 (A) & S-964 & $3 / 21 / 2014$ & $5: 12$ & $<0.010$ & 0.537 & 0.537 & All Fe ${ }^{3+}$ & All Fe ${ }^{3+}$ \\
\hline CEF2-GL-119 (B) & S-964 & $3 / 21 / 2014$ & $5: 12$ & $<0.010$ & 0.535 & 0.535 & All Fe $\mathrm{Fe}^{3+}$ & All Fe ${ }^{3+}$ \\
\hline CEF2-GL-120 (A) & S-965 & $3 / 21 / 2014$ & $1: 10$ & $<0.010$ & 0.575 & 0.575 & All Fe ${ }^{3+}$ & All Fe $\mathrm{Fe}^{3+}$ \\
\hline CEF2-GL-120 (B) & S-965 & $3 / 21 / 2014$ & $1: 10$ & $<0.010$ & 0.575 & 0.575 & All Fe ${ }^{3+}$ & All $\mathrm{Fe}^{3+}$ \\
\hline
\end{tabular}




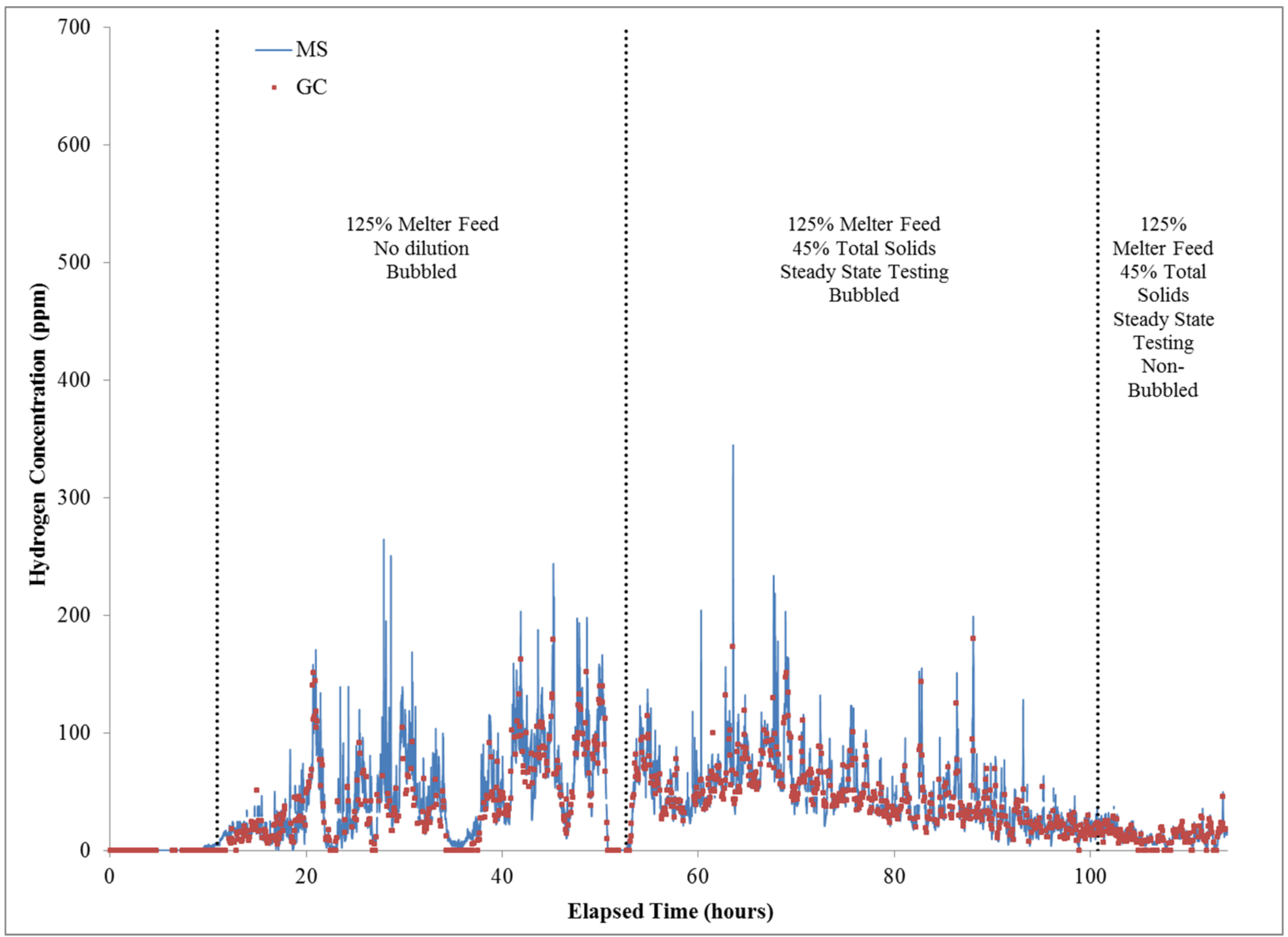

Figure A-51. Hydrogen generation (elapsed time $=0$ at 12:00 February 24, 2014). 


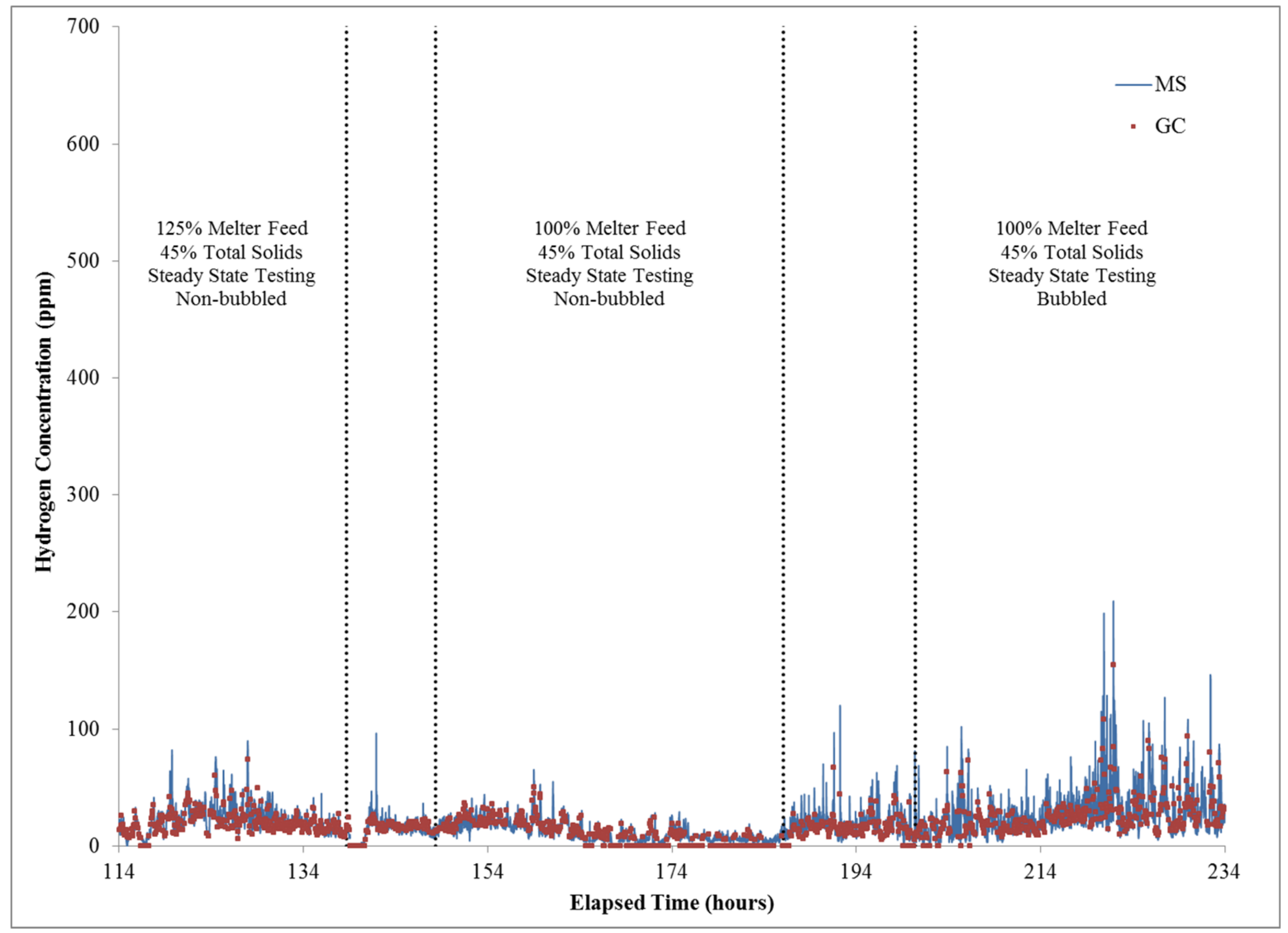

Figure A-52. Hydrogen generation (elapsed time = 114 hours at 6:00 March 1, 2014). 


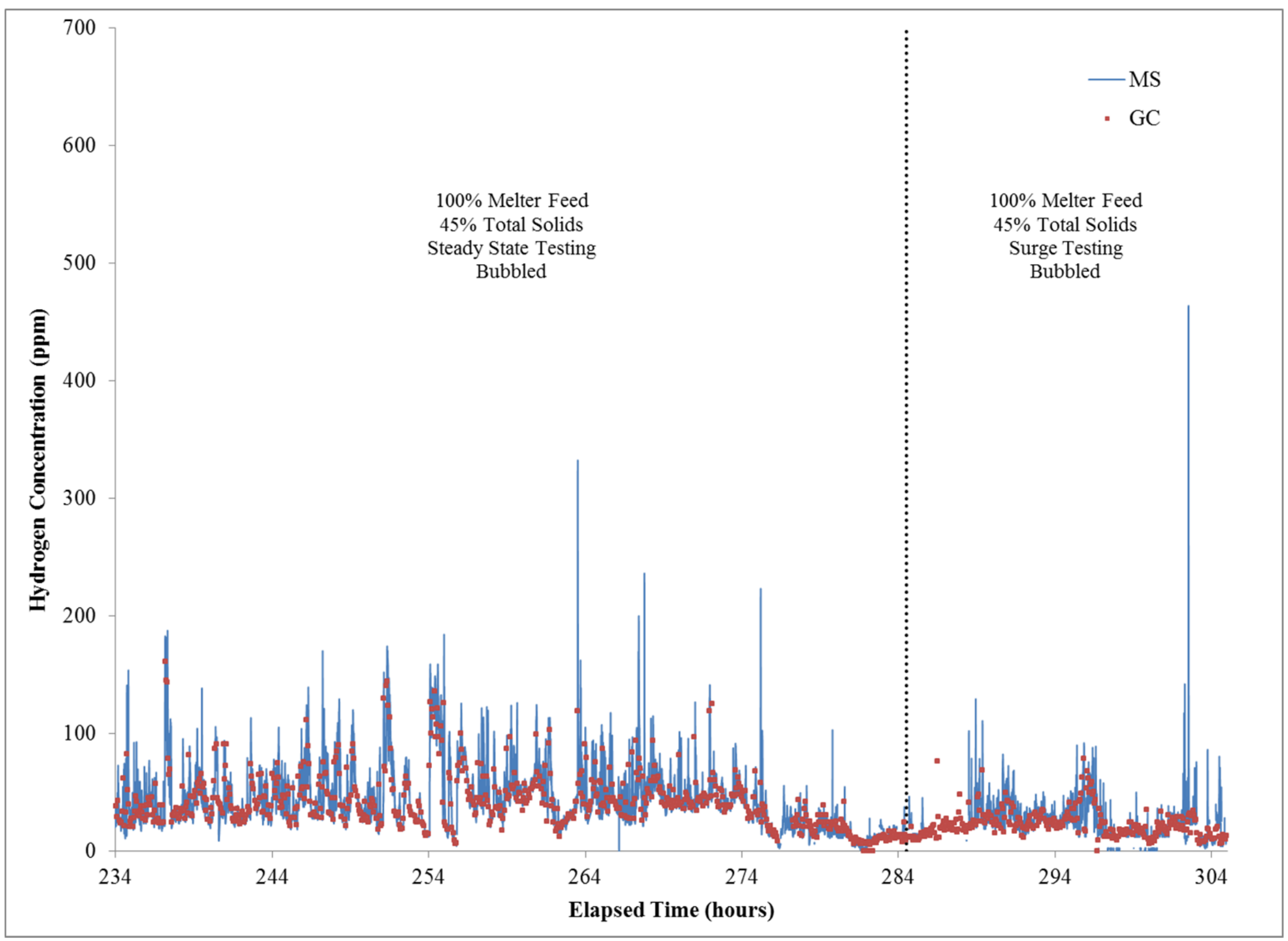

Figure A-53. Hydrogen generation (elapsed time = 234 hours at 6:00 March 6, 2014). 


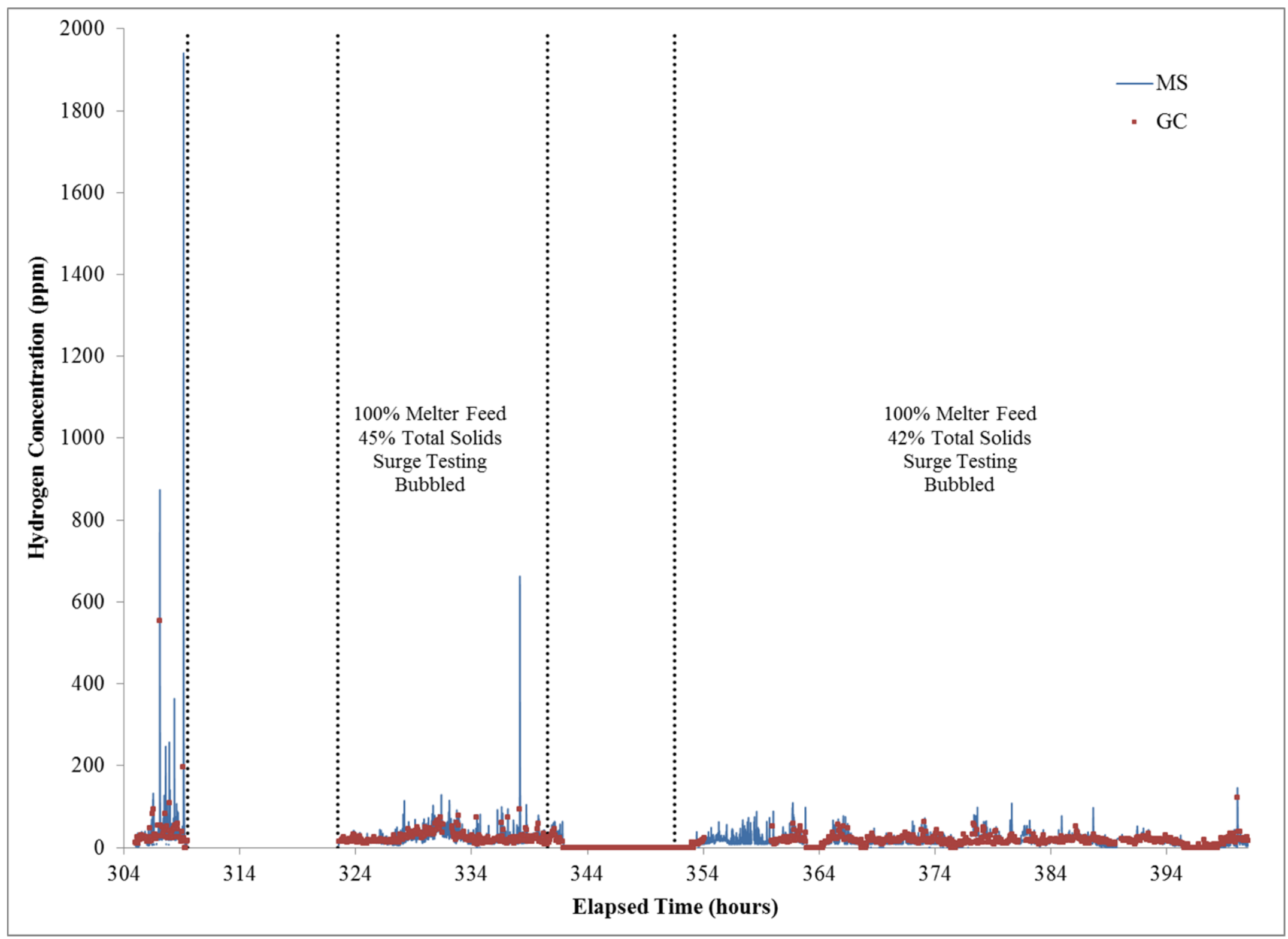

Figure A-54. Hydrogen generation (elapsed time = 305 hours at 6:00 March 9, 2014). 


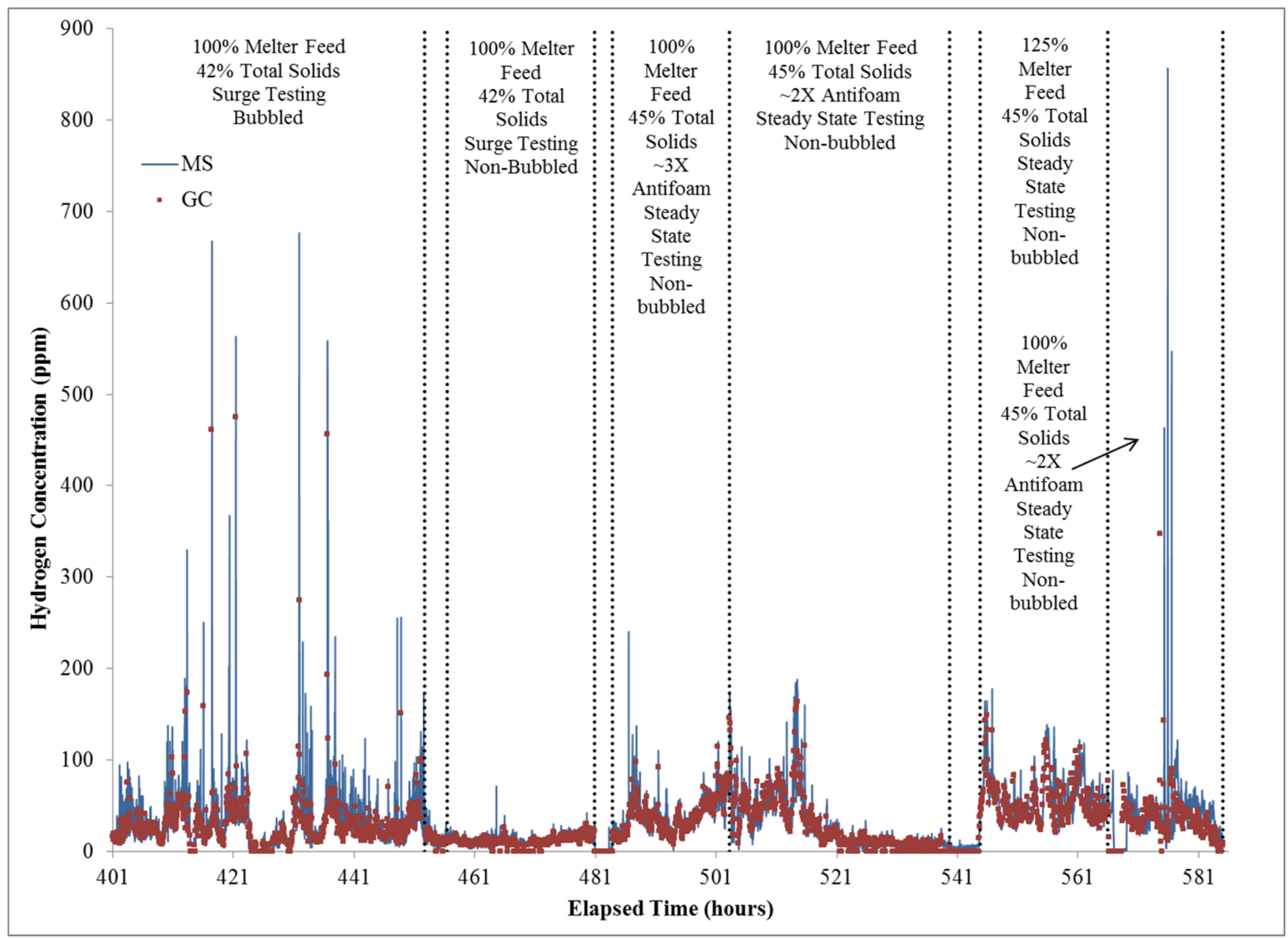

Figure A-55. Hydrogen generation (elapsed time = 401 hours at 6:00 March 13, 2014). 


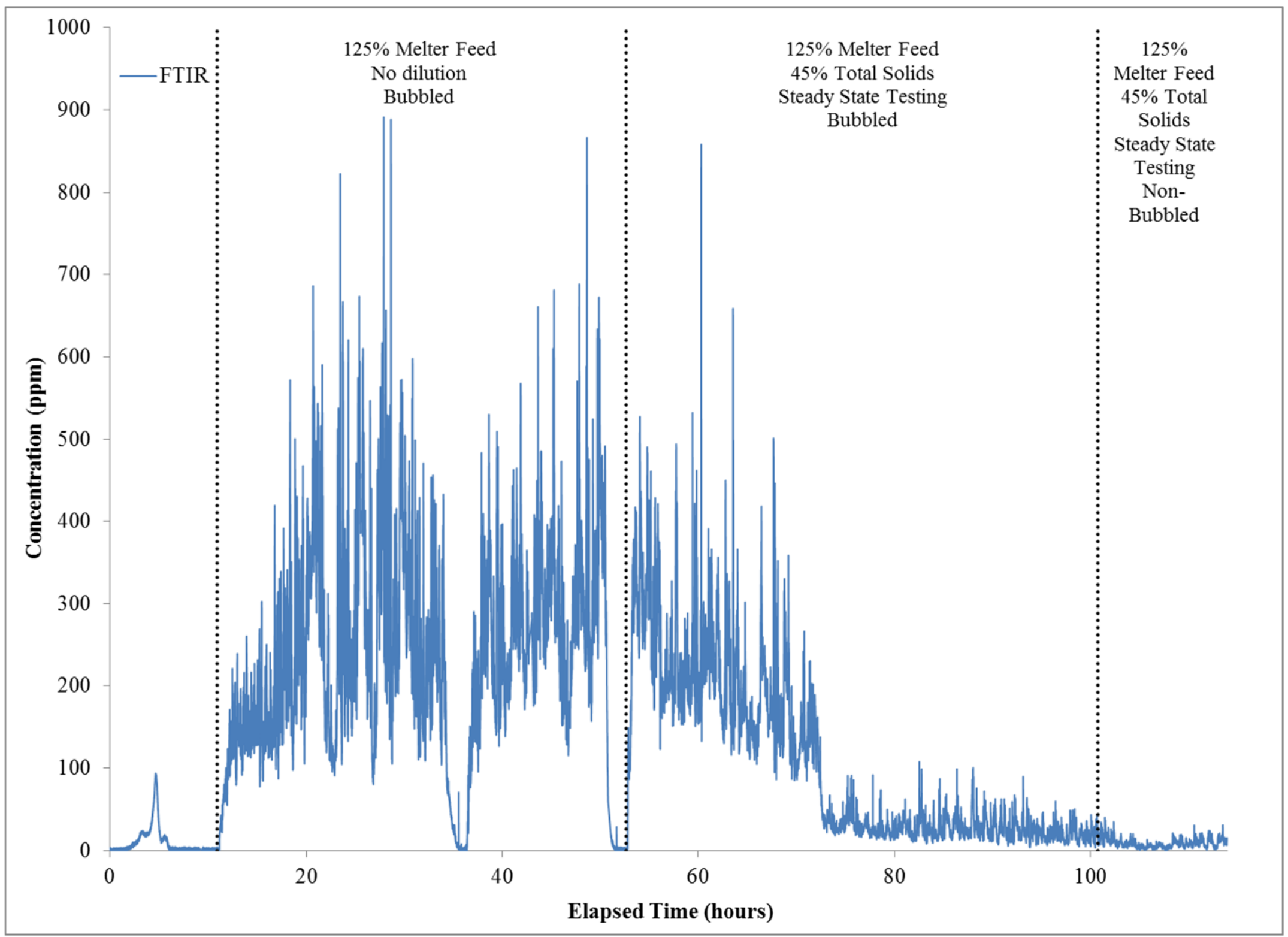

Figure A-56. Carbon monoxide generation (elapsed time $=0$ at 12:00 February 24, 2014). 


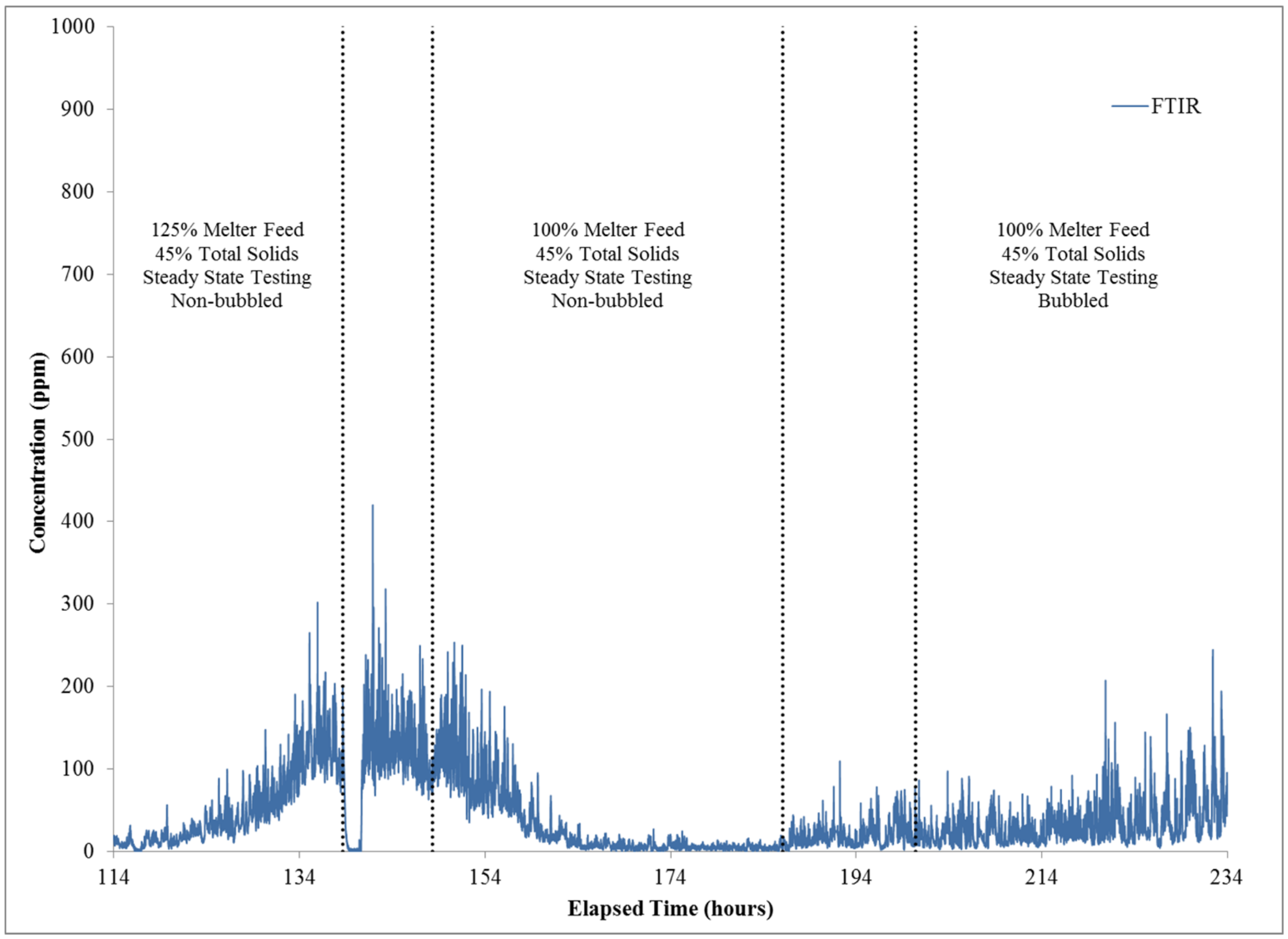

Figure A-57. Carbon monoxide generation (elapsed time = 114 hours at 6:00 March 1, 2014). 


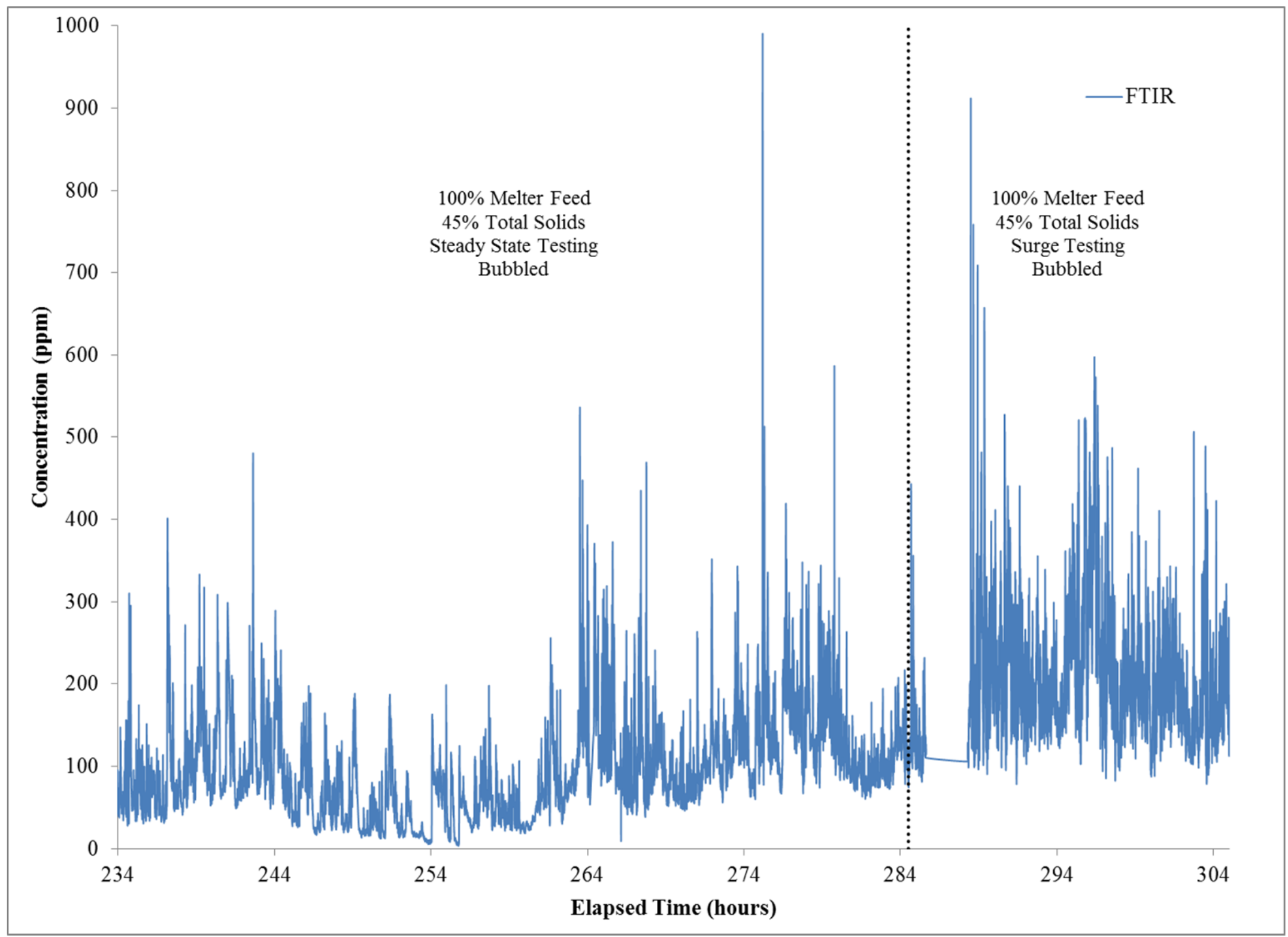

Figure A-58. Carbon monoxide generation (elapsed time $=234$ hours at 6:00 March 6, 2014). 


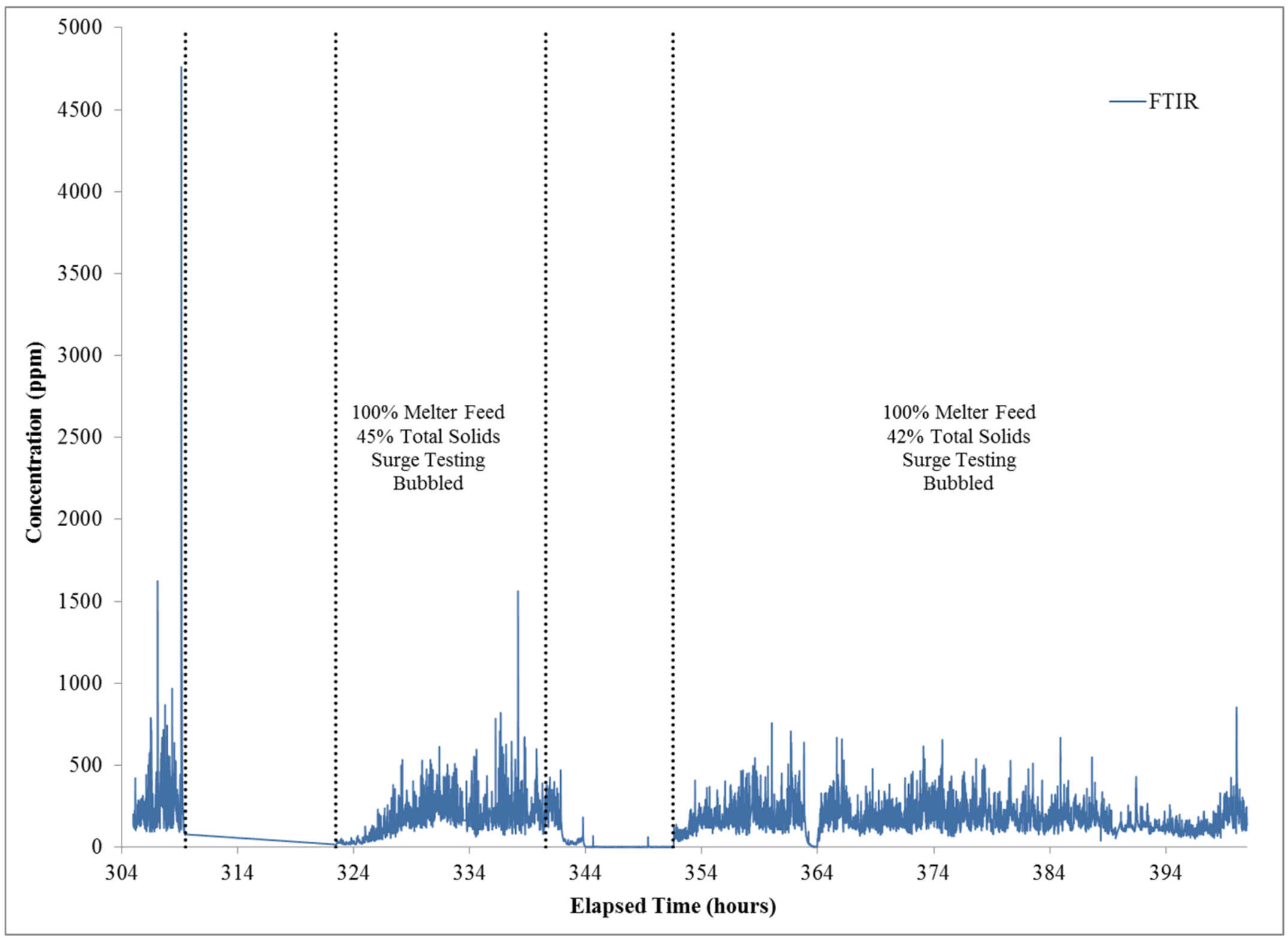

Figure A-59. Carbon monoxide generation (elapsed time $=305$ hours at 6:00 March 9, 2014). 


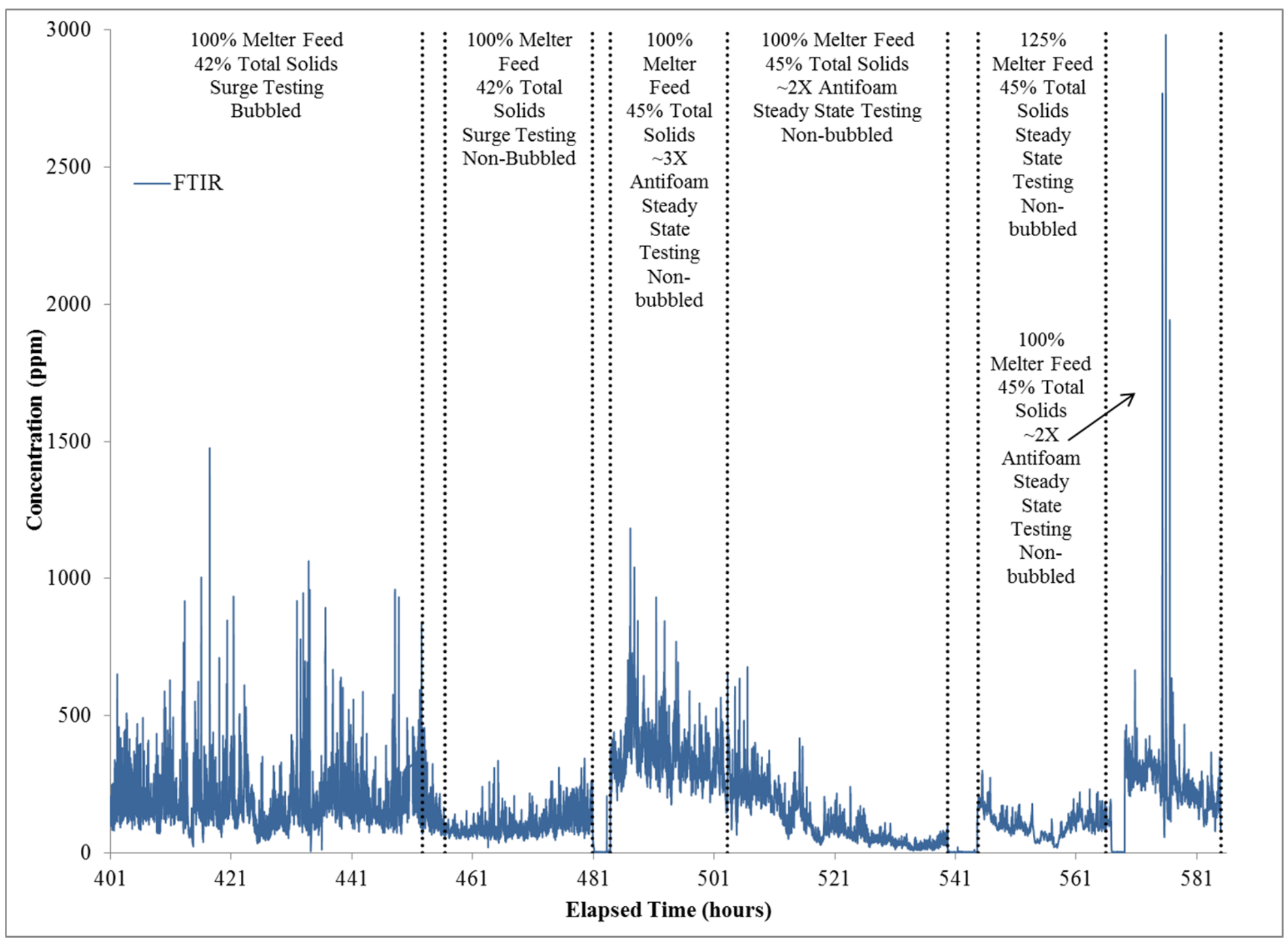

Figure A-60. Carbon monoxide generation (elapsed time $=401$ hours at 6:00 March 13, 2014). 


\section{Distribution:}

S. L. Marra, 773-A

T. B. Brown, 773-A

D. H. McGuire, 999-W

S. D. Fink, 773-A

C. C. Herman, 773-A

E. N. Hoffman, 999-W

F. M. Pennebaker, 773-42A

W. R. Wilmarth, 773-A

Records Administration (EDWS)

J. M. Bricker, 704-30S

R.E. Edwards, 766-H

T. L. Fellinger, 766-H

E. J. Freed, 704-S

J. M. Gillam, 766-H

B. A. Hamm, 766-H

E. W. Holtzscheiter, 766-H

J. F. Iaukea, 704-27S

D. K. Peeler, 999-W

J. W. Ray, 704-27S

P. J. Ryan, 704-S

H. B. Shah, 766-H

D. C. Sherburne, 704-S

M. E. Stone, 999-W

M.E. Smith, 704-30S

S.T. Isom, 766-H

W.O. Pepper, 704-71S/5

H.P. Boyd, 704-27S

A. Samadi-Dezfouli, 704-27S

S.G. Phillips, 704-25S

P. R. Jackson, DOE-SR, 703-46A

V. Jain, 766-H 